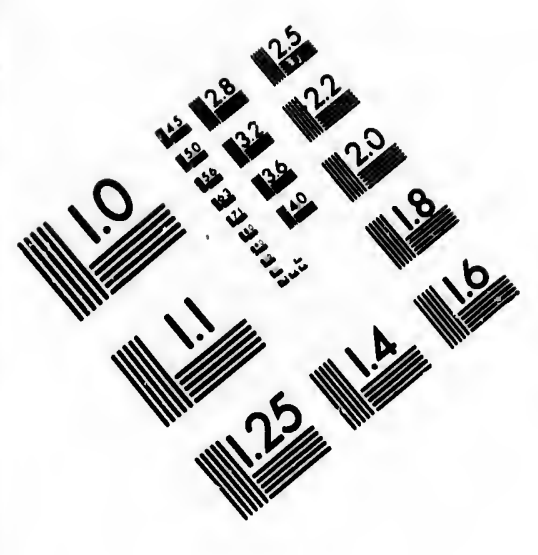

IMAGE EVALUATION

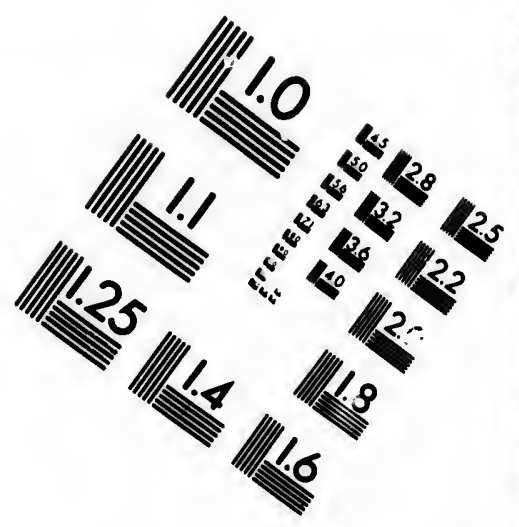

TEST TARGET (MT-3)
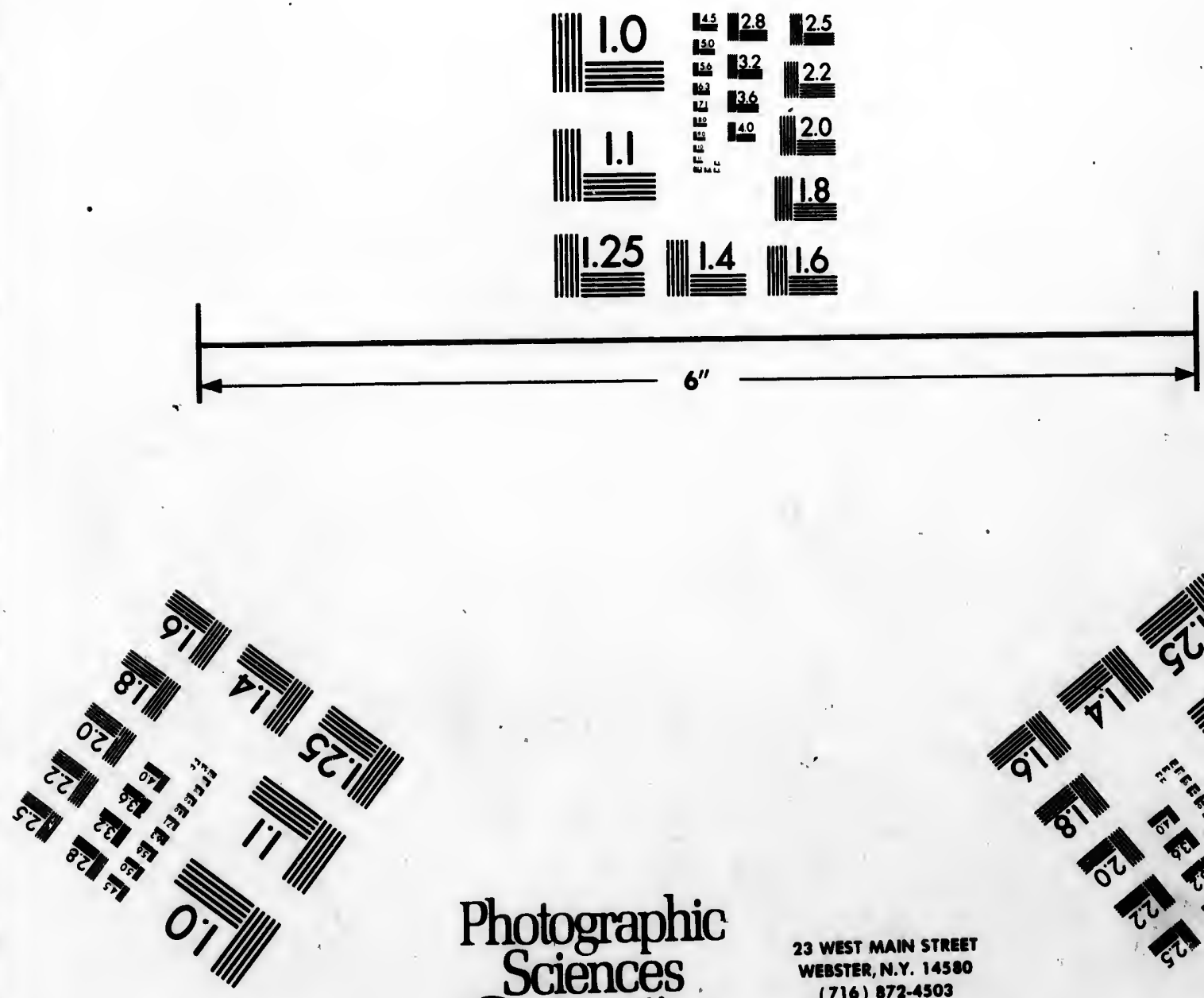

Photographic Sciences

23 WEST MAIN STREET WEBSTER, N.Y. 14580

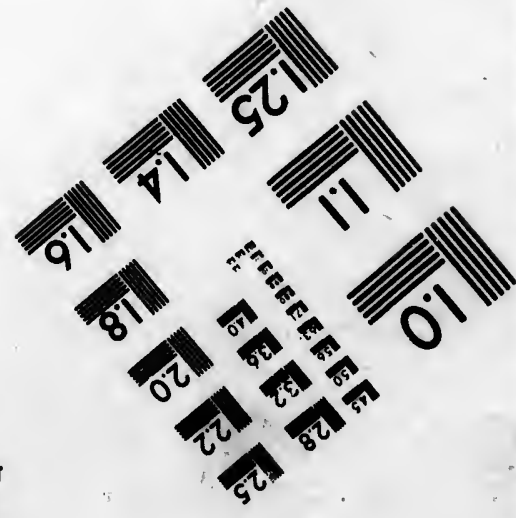
Corporation 


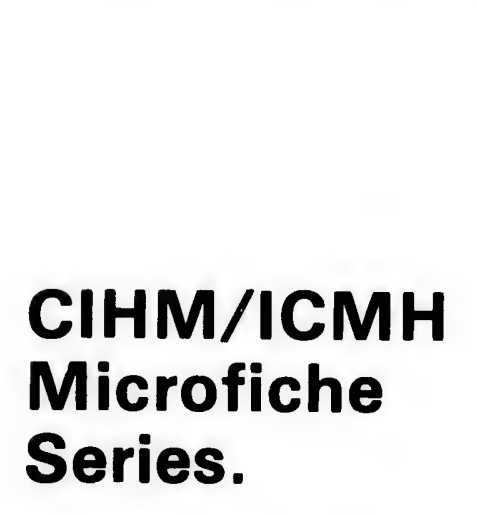

CIHM/ICMH Collection de microfiches.
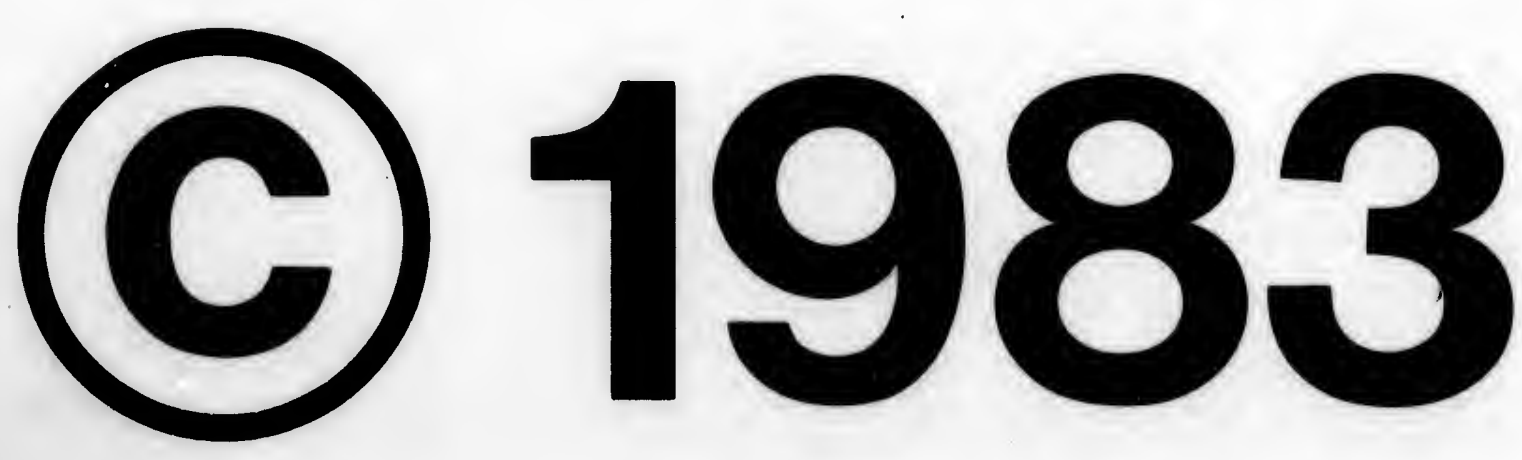
The Institute has attempted to obtain the best original copy available for filming. Features of this copy which may be bibliographically unique. which may alter any of the images in the reproduction, or which may significantly change the usual method of filming, are checked below.

Coloured covers/

Couverture de couleur

Covers damaged/

Couverture endommagée

Covers restored and/or laminated/

Couverture restaurée et/ou pelliculée

Cover title missing/

Le titre de couverture manque

Coloured maps/

Cartes géographiques en couleur

Coloured ink (i.e. other than blue or black)/

Encre de couleur (i.e. autre que bleue ou noirel

Coloured plates and/or illustrations/

Planches et/ou illustrations en couleur

Bound with other material/

Relié avec d'autres documents

Tight binding may cause shadows or distortion along interior margin/

La reliure serrée peut causer de l'ombre ou de la distortion le long de la marge intérieure

Blank leaves added during restoration may

appear within the text. Whenever possible, these have been omitted from filming/

II se peut que certaines pages blanches ajoutées lors d'une restauration apparaissent dans le texte. mais, lorsque ceia était possible, ces pages n'ont pas été filmées.

Additional comments:/

Commentaires supplémentaires:
L'Institut a microfilmé le meilleur exemplaire qu'il lui a été possible de se procurer. Les détails de cet exemplaire qui sont peut-être uniques du point de vue bibliographique, qui peuvent modifier une image reproduite, ou qui peuvent exiger une modification dans la méthode normale de fiimage sont indiqués ci-dessous.

Coloured pages/

Pages de couleur

Pages damaged/

Pages endommagées

Pages restored and/or laminated/

Pages restaurées et/ou pelliculées

Pages discoloured, stained or foxed/

Pages décolorées, tachetées ou piquées

Pages detached/

Pages détachées

Showthrough/

Transparence

Quality of print varies/

Qualité inégale de l'impression

Includes supplementary material/

Comprend du matériel supplémentaire

Only edition available/

Seule édition disponible

Pages wholly or partially obscured by errata slips, tissues, etc.. have been refilmed to ensure the best possible image/ Les pages totalement ou partiellement obscurcies par un feuillet d'errata, une pelure. etc.. ont été filmées a nouveau de façon a obtenir la mnilleure image possible.

This item is filmed at the reduction ratio checked below/ Ce document est filnié au taux de réduction indiqué ci-dessous.

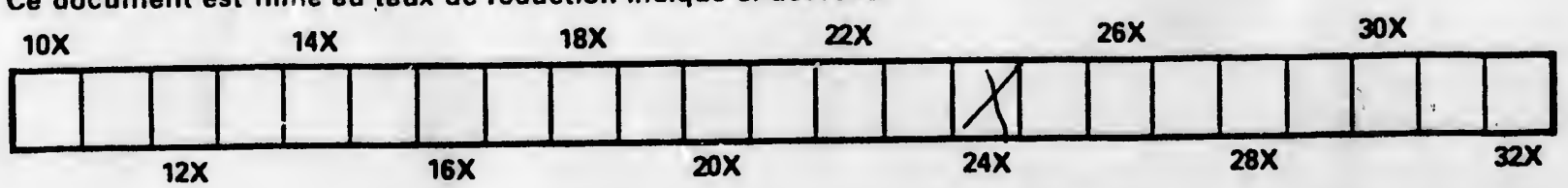


The copy filmed here has been reproduced thanks to the generosity of:

\section{Librery of Congress Photoduplication Service}

The images appearing here are the best quality possible considering the condition and legibility of the original copy and in keeping with the filming contrect specifications.

Original coples in printed paper covers are filmed beginning with the front cover and ending on the last page with a printed or illustrated impression, or the back cover when appropriate. All other original copies are filmed beginning on the first page with a printed or lllustrated impression, and ending on the last page with a printed or illustrated impression.

The last recorded freme on each microfiche shall contain the symbol $\rightarrow$ (meaning "CONTINUED"), or the symbol $\nabla$ (meaning "END"), whichever applies.

Maps, plates, charts, etc., may be filmed at different reduction ratios. Those too large to be entirely included in one exposure are filmed beginning in the upper left hand corner, left to right and top to bottom, as many frames as required. The following diagrams illustrate the method:
L'exemplaire filmé fut reproduit grâce à la générosité de:

\section{Library of Congress}

Photoduplication Service

Les imeges suivantes ont été reproduites avec le plus grend soin, compte tenu de le condition et de le netteté de l'exemplaire filmé, et en conformité avec les conditions du contrat de filmage.

Les exemplaires originaux dont le couverture en papier est imprimée sont filmés en commençant par le premier plat et en terminant soit par la dernière page qui comporte une empreinte d'impression ou d'illustration, soit par le second plat, selon le cas. Tous les autres exemplaires originaux sont filmés en commençant par le premiere page qui comporte une empreinte d'impression ou d'illustration et en terminant par la derniere page qui comporte une telle empreinte.

Un des symboles suivants apparaîtra sur la derniére image de chaque microfiche, selon le cas: le symbole $\rightarrow$ signifie "A SUIVRE", le symbole $\nabla$ signifie "FIN".

Les cartes, planches, tableaux, etc., peuvent être filmés a des taux de réduction différents.

Lorsque le document est trop grand pour être reproduit on un seul clichs, il est filmé ầ partir de l'angle supérieur gauche, de gauche à droite, ot de haut en bas, on prenant lo nombre d'images nécessaire. Les diagrammes suivants illustrent la méthode.
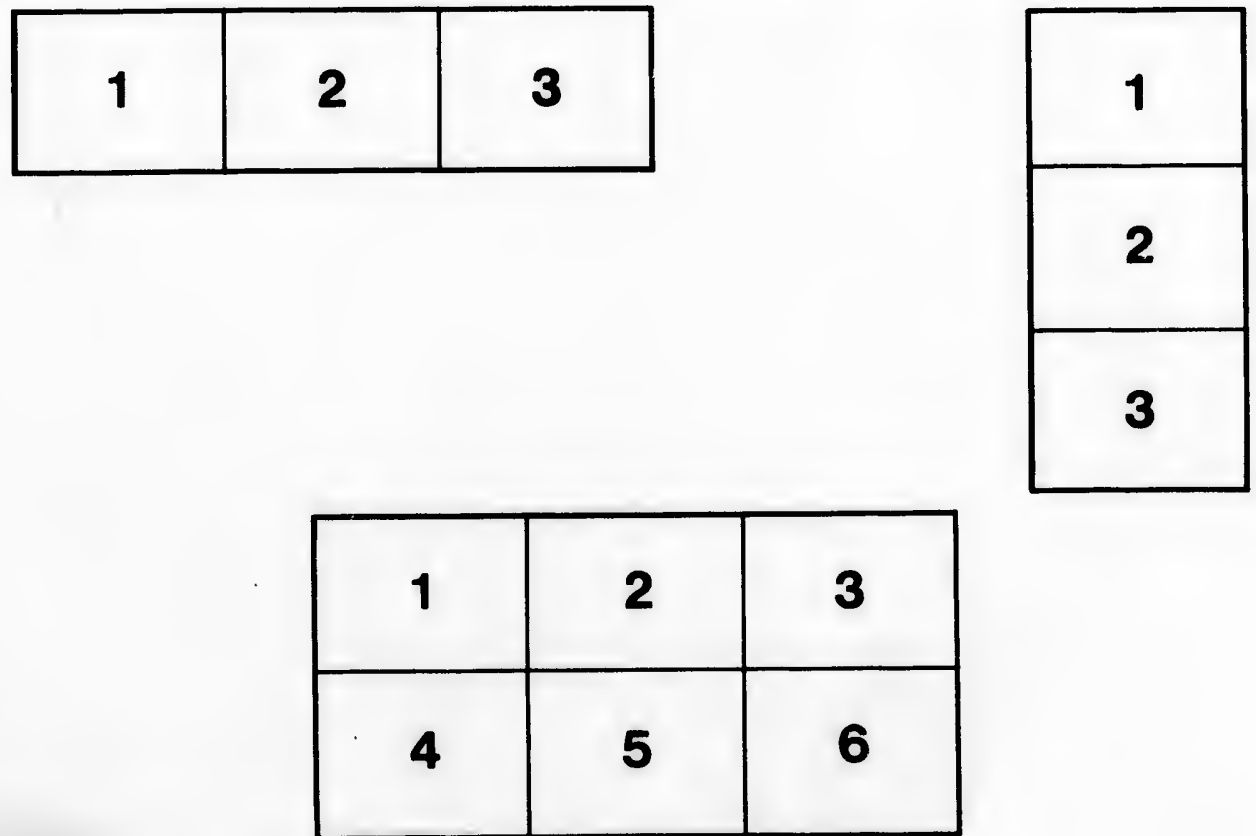


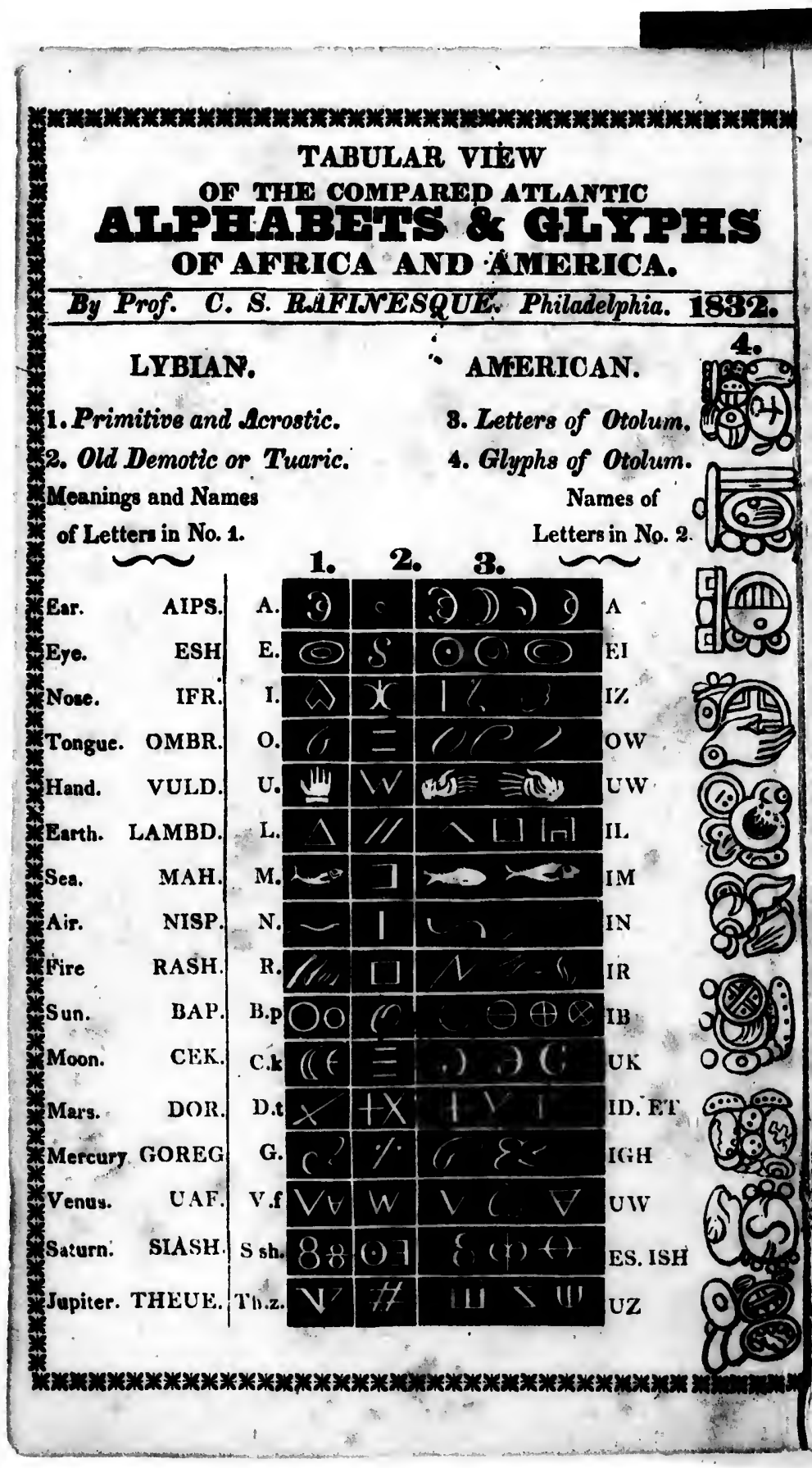




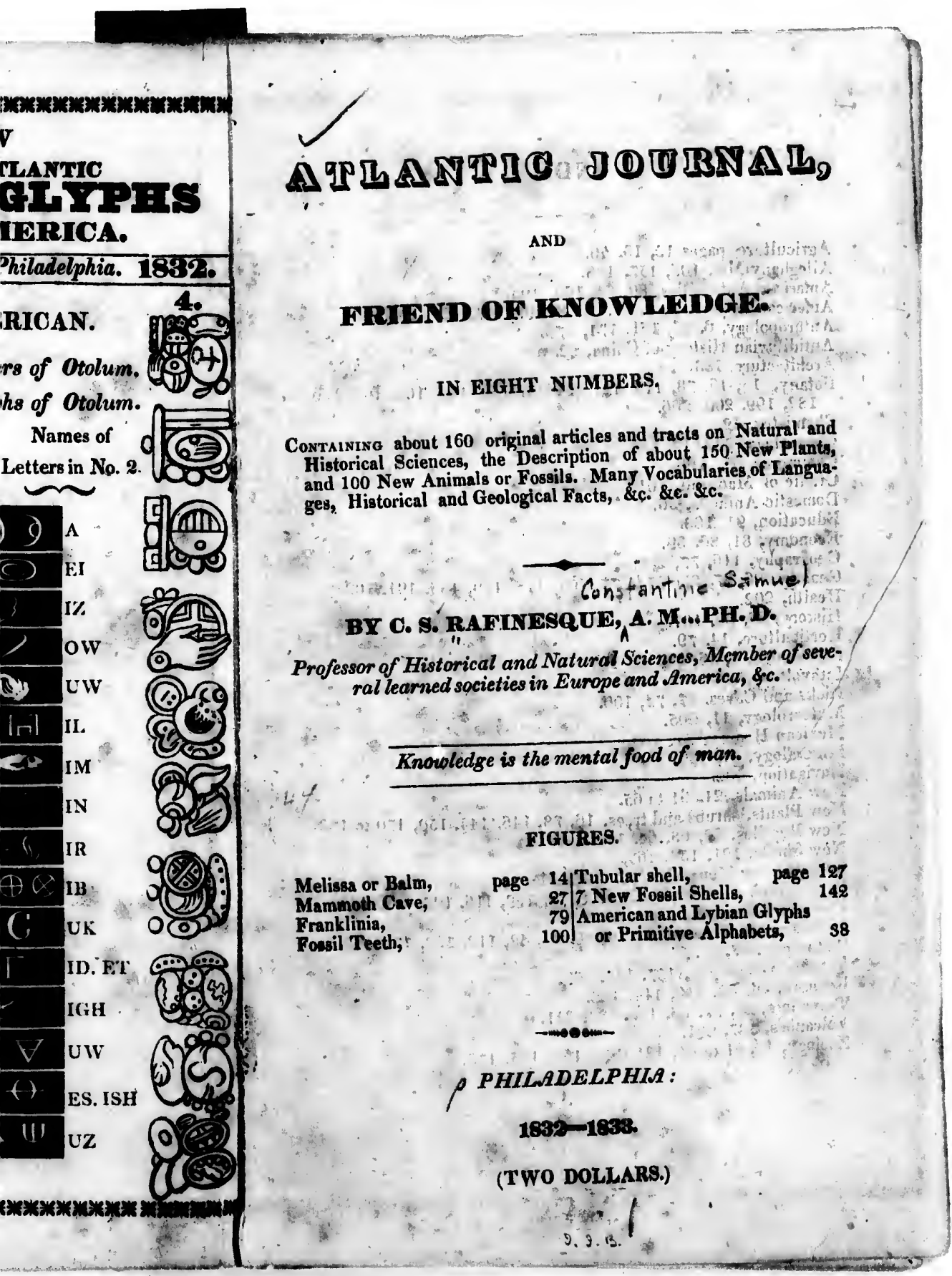




\section{INDEX.}

Agriculture, pages 12, 13, 56.

Alleghany Mts, 105, 157, 188.

American Antiquities, R0, 81, 126, 195.

American Hitotory, 6, 8, 51, 56, 85, 98, 117, 127, $195,197$.

Anthropology, 6, 85, 161, 171, 172.

Antidiluvian History of China, 22.

Architecture, 183.

Botany, 15, 16, 78, 119, 121, 144 to 15s, 163, 164, 167, 176 to $182,199,200,206$.

Chemistry, 12.

Chronology, 22, 117, 130

Commerce, 32,166

Cradle of Mankind, 101.

Domestic Animals, 56 .

Bducatioy, 91, 183.

Economy; 81, 86, 89.

Geography, 116, 77, 208.

Geology, 26, 27, 30, 65 to 77, 105, 115, $119,135,191,209$.

Health, 202.

History, 22, 26, 101.

Horticulture, 14,79 .

Knowledge, 1,$36 ; 99,93,124$.

Icthyolog, 141 .

Ijicks and Caves, 27, 74, 100.

Meteorology, 11, 205.

Mexican History, 51,128

Mineralogy, 31, 140

Navigation, 202 .

Niew Animals, 21, 61 to 65 .

New Plants, shrubs and trees, 16, 78, 146, 144, 150, 170 to 182.

New Reptiles, 22, 63, 64; 121, 143 .

New Shells, 121, 154, 165.

Orography or Mountains, 77, $101,105$.

Oryctography or new fossils, of to $74,109,116,122,149,143$.

Peruvien Dynusties, 130.

Philology and Vocabulaties, $4,40,44,48,112,132,173,198$.

Philosophy, 48, 95.

Physical Geography, 187, 188, 209.

Reviews, 34, 82, 110, 114, 122.

Travellers, 26, 77, 85, 155, 187, 211.

Volcanoes, 137, 201.

Zoology, 18, 61 to 65, 121, 143, 163, 165, 175. 


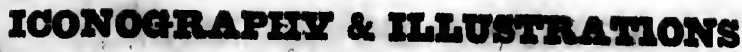

\section{OF 33 YEARS TRAVELS AND RESEARCHES}

In North America, the South of Europe, the Atlantic and Mediterranean, Sicily and the Azores, between 1800 \& 1833.

I C. S. RAFINESQUE,

Professor of Historical and Natural Sciences Member bo several learned Societies in Paris, Bruxelles, Zurich, Vienna, Bonn, Naples, New-York, Philadelphia, Lerington, Cincinnati, \&c.

\section{IN 30 VOLUMDS IN FOTIO.}

\section{INIQUE COPY,}

contanning

3000 Figures, Maps, fo, with MSS. Notes and Explanations. PRICE 81000.

Each Volume or Part sold separate, at the rate of 850 , for 100 figures, \&c.-Divided into the 10 following parts:

1st Part, Soenzry - 300 Views; Landscapes, Meteors, and Phe$2 d$ Part, Geogarn nomena.

-200 Maps, plans, surveys, sites, cities, of ancient and modern Ameriean Geograsd Part, Georocr-200 Ghy Phical Geography, \&c.

4th Part, Eections, views, \&c.

and features of of eminent men, costumes 5th Part, Aronzologr-300 plans antions, \& cuins, implements, \&c.

7th Part, Orrctocr-200 compared al phabets, glyphs, languages. 8th Part, Zoologr - 500 New Animals merican Fossils, \&c.

8th Part, ZooLOG Y -500 New Animals, chiefty American.

9th Part, Borany-400 New Plants, chiefly American.

10th Part, Miscrilany - 200 Autographs and Figuires of Diseases Monstruosities, Machines, Sometry, and other Scienees.

PHILADELPHIA:

1815110 1883: 


\section{AUHWEON BOTANIFON,}

olly

\section{SELF FIGURES, BY SPECIMENS,}

of New or Rare Trees, Vines, Shrubs, Plants, Flowers, Grasses, Ferns, \&c. from North America.

Collected and Arranged between.. 1815 and 1833,

By C. S. RAFinesque, A.M ... Ph. D.

Professor of Botany, Historical and Natural Sciences, Member of many learned Societies, Author of many Botanical Works,

Traveller, Collector, and Draughtsman.

WITH APPENDIX AND SUPPLEMENTS,

Cf 500 New, Rare, or Bcautiful Plants, from Mexico, South America, Africa, Polyncsia, Asia and Europe.

DIVIDED INTO 25 VOLUMES, FOLIO, UNIQUE COPY,

And 50 additional series or fascicles of Plants,

From the Oregon, Apalachian and Alleghany Mts., the Regions of Louisiana, Arkansas, Missouri, Oreron, Illinois, Kentucky,

Tennessee, Alabama, Florida, Carolina, Virginia, Canada, Labrador, \&c. \&c. \&c.

With Labels, Notes, and Details.

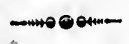

rrices-Unique complete series of 2500 species,

Fascicles of N. G. and N. Sp. and setts of Monographs

laivelled, per 100 specimens.

Kare Plants, labelled, per 100

Other Plants, labelled, per: 00 ,

Unlabelied Plants, per 100, 


\section{ALTHATHC JOURATAT,}

\section{PRIIBND OIP KNTOWIIBIAI:}

$\triangle$ CYCLOPEDIC JOURNAI AND REVIEW

MISTORICAL, NATURAL, AND MEDICAL ARTS AND BCIENCE:

INDUSTRY, AORICULTDRE, EDUCATION, AND EYERY USEFOL INYOAYATIOW:

WITH NUMEROUS FIGURES.

EDITOR, C. S. RAFINESQUE,

I'rofessor of Historical and Natural Sciences, \&c.

Vol. I. $\frac{\text { PHILADELPHIA, spring or 1832. Mman, No. 1: of }}{\text { Knowledge is the mental food of man. }}$

INTRODUC'TION. "any pretensions. and none of the

Perrodronls abound in the Uni- usual pompous promises. It will ted States; but those calculated to be of a atrikingly novel character, improve and instruct, to scatter the and must be left to speak for itself; seeds of learning, and become ensi- to deserve by its own intrinsio nently useful by rendering all kind value and merit the patronage which of knowledge and improvements it claims from all the friends of popular, are as yet but few and knowledge, education and learning: costly; thus beyond the means of The Editor being always in purthose whom they are most likely to suit of knowledge, will be able to benefit. It is auch a deficiency that furnish most of the articles, when this journal is partly intended to not proffered by his collaborators. supply.

It is contemplated therefore to DoLuAk per annum, or Two DoLLARs publish, in the city of Philadelphia, for each volume of twelve numbers, a new periodical journal under the or four hundred pages, title-page, above title. It will be sonducted index, and nearly fifty figures. This by Prof. Rafisesque, assisted by periodical is begun in a quarterly several gentlemen of considerable form, but it is hoped may aoon betalent and knowledge.

This journal shall contain every Communications for this Journal, thing calculated to enlighten, in- may be left at the post office or sent struct, and improve the mind. It by mail, postage pa; None will will not be confined to any narticu- be calculated for this pher unless lar branch of literature and science, very terse and concise, either usebut embrace by turns every subject ful or novel in character or purpose: useful or interesting. Agriculture new facts will be acceptable abore and economy, with discoveries in all. Anonymous papers or Reviews the useful arta and practical sci- will very seldom be accepted. ences, will claim peculiar attention. Every writer ought never to bo Literature shall not be forgotten; ashamed of his pen and deods. The it is also a branch of knowledge, initials of C.S. R. will designate the but facts shall have the preference editorial articles. over fiction. Reviews will be introduced on the new plan of stating the increase of knowleclge aftorded by broks. The whole is intended to be original inatter; selections shall seldom be resorted to.

1. LATENT KNOWLEDGE.

Besides the actual active, know. ledge of mankind, forned by the accumulation of exertions in all the branches of human ecquirements;

-This journal is ventured withont and spread in the numberless bock 1 
on education, the arts and sciences, they bow to some idols of yore, history and literature: there is an. and copy or compile from them other mass of knowledge, which may without discernment nor carcful inbe rilled latent or sleeping. The vestigation of previous labours by amount of it is mucls greater than other men or nations. We can could be supposed. Ficre are in hardly open a work of history, traall the branches of knowledge, some vel, or science, without meetin portions nearly forgotten and lost which gradually sink into oblivion and are lost to mankind; like the im mense amount of facts, events ani practices, which have thus become extinct during the lapse of ages.

If all the extinct knowledge was yet existing, it might exceed perhaps what is now extant, although we deem it prodigious. Every friend of learning has to regret the loss of anme past knowledge, of which faint indications or small fragments merely remain. But if the latent knowledge be added, as it is eventually by the neglect of ignorance, the whole of this dormant or forgotten, together with the dead or lost, both of which are now ren. dered useless to mankind, will be found prodigious.

But fortunately the latent or dormant may yet be restored and rendered available, by care, patient researches and exertions. It is to be found scattered in old books, or even new publications of limited circulation, in manuscripta, in the memory of men, in monuments that speak a peculiar language to be learnt and restored. All this among us. But further off, wo liave in the literature and books of Asia from Persia to India, China and Japan, an inexhaustible mine of learning, hardly explored as yet. The Asiatic nations, were the first tcachers of mankind; their western children who boast of having surpassed them in every thing, have neglected their old teachers for ages; but now begin to interrogate them again.

Ourattention shall often be Irawn towards this subject. It is deplorable to see the servility, laziness and ignorance of many of our popular writers on all subjects. They vill not take the trubble to enquires

cience, without meetin

ignorance. All our books of edu-
insand instances of neglect and cation are sadly deficient, except on those matters lately investigated.

Facts, events and discoveries without number are set aside, not attended to, or aven not known. T'o this shameful practice, which tlireat

ens a true Vundalic destruction of knowledge, we mean to draw the attention of the public, and expose it in all its turpitude and injurious bearings. C. S. R.

2. PUBI.IC INSTRUCTION. Free Institutions of Paris and France.

The following concise account of those Institutions, and their wonderful effect upon the French people, is not derived from any doubtfol source or formal friend; but chiefly from the pen of Sir Arthur Faulkner, an Englishman, who visited France in 1827 for the purpose of investigating the subject of such free Institutions: and fron an analytical abridgement of the work published by him on his return. The are obvious and luminous facts, spesking volumes in favour of free Ellucation.

The total number of general schools in Paris was 647 in 1827 . having 60,000 sch.olars. They were chicfly 294 Infant schuols, all gratis, teaching reading, writing, and arithetic, and elements of drawing.

53 primary schools for boys. 51 ditto for girla. 22 Sunday scliools.

12 Schools of mutual Instruction r boys.

5 ditto for girls. 100 Boarding schools for boys. 110 ditto for girls.

Besides. innumerable peculiar 
- idols of yore, apile from them nt nor careful in. vious labours by tions. We can k of history, trawithout meeting 8 of neglect and ur books of eduficient, except on ely investigated. discoveries withet aside, not atnot known. To ice, which threat. ic destruction of ean to draw the ublic, and expose ule and injurious C. S. R.

STRUCTION. is of Paris and ice.

oncise account of , and their won. the French peofrom any doubt. rmal friend; but ien of Sir Arthur ishman, who visit7 for the purpose e subject of such and from an ana$t$ of the work pubis return. They luminous facts in favour of free nber of general vas 647 in 1827 , olars. They were schools, all gratis, writing, and arithits of tra wing. ols for boys. for girls. uls. utual Instruction for girls. chools for boys. for girls. nerable peculiar ig, Painting, Ar- chitecture, Masonry, Carpentry, No present is allowed, much less Music, Languages, Mathematics, exacted as in England by servanto and all the sciences. and underlings.

The schools are all free and gra. The same happens all over France. tuitous, except the Boarding schools. Free schools are scattered over the The girls are taught sewing, handy- whole country, and free Institutions, work, embroidery, and all the trades Libraries, Museums, Gardens, Lysuitable and befitting females to earn ceums, \&c., in all the principal a living!

There are also schoolo for the un- town and cities. Lectures on fortunate for fortunate, for the blind, the lanie, mers, on trades by meohanics.

the cripples, the deformed, all of The expenses of these free Instiwhich are taught trades suitable to tutions are borne by the state, the their atate, and enabling them to cities,or foundations for the purpose; earn their living by useful labor. but chiefly paid out of the public ex-

There are 34 public libraries in pense, under the title of Public InParis, all free to every one, open struction. - The most useful, and and accessible every day, with po. most honourable mode of spending lite librarians and servants to belp public money.

readers. The largest, or the royal

library, contains 500,000 volumes! The happy results of this state of the next 170,000 , the third 93,000. thinga, are that the French are beThe library of the Institute has come a great people, at the head of 70,000 volumes, tise city. library civilized Europe, and withal a mo42,000; the other from 2000 to ral people! much better off and 30,000. French books are printed more moral than the English. The and sold at one-third of the price of former idle gallantry and vicious. English books, with a rapidity be- courses are become quite uncomyond belief, and thus circulated all mon. The French peasantry are over Europe. Old books and se- industrious, frugal, orderly, kind, cond-hand books are sold for a mere cheerful and contented. There are trifle in the streets by 1000 pedlars, no paupers as in England. A few or on benches. The public garden and museum, culiar circumstances, if unlicensed are the Emporium and palace of they are taken up as vagabonde. natural sciences. Open and free to Vices and crimes are much less in every one; in the garlen, agricul- number and atrocity than in Engture and gardening are taught gra- land. Wine' sells every where for tis, and seeds given to all who ap- one to three cents the bottle, yet ply. All the natural sciences are intoxication is hardly known. No taught by free lectures and demon. brandy, and no alcoholic liquors are atrations to whoeverattends. drunk to poison and brutalize the The Louvre, or palace of fine arts, body and mind.

is opened to the public every day, Sir A. Faulkner exclaims in deseven Sundaya, and crowded by vis. pair: "England is famous for charitors.

Fifty other Institutions have ities to the helpless, but neglects to culiar Cabir culiar Cabinets,Museums,Galleries, selves. When we reflect on the with free admittance and free lec- peculiar facilities of access to booke, tures; in all the medical sciences, lectures, museums, cabinets, \&cc. in History and Literature, Mining, Paris and all over France, gratis to Engineering, \&c. $\quad$ all, we have a ready solution why

No fees are taken by Professors the French community at lan why and Assistants, for teaching, de-so much advanced in civilization monstrating and waiting on visitors. and refinement, before any other: 
country in the world!" Thls con-(rican nationt, but not properly itfoasion comes frum an Englishman. lustrated. Their full development

In the United States, we initate, would require a volume, like that of as yet, England in almost every yours on the Figyptian antiquities, thing, good or bad. 'I'hus we can and may follow this perhaps at sume hardly believe that it is possible to future time.

have Free Inatitutions, Colleges, It may be needful to prefix the Lectures, Libraries, Museums, \&cc. following principles as quides to my without paying at least a fee of 25 reacarches, or results of my iuquicents each time we visit them, or ries.

an annual subscription. And thus 1. America has been the land of wo have intemperance, immorality, false systems; all those made in paupers, ignorance-with all their Europe on it are more or less vain baneful consequences. What ought and erroneous.

to be done, and what free Institu- 2. The Americans were equal in tions are immediately required to antiquity, civilization, and sciences foster preserve and secure, the fu- to the nations of Africa and Europes ture liberties and morals of our peo- like them the children of the $A$ siatio ple, will be indicated at a future nations.

time. Public Instruction or the ac- 3 . It is false that no American quirement of knowledge, by all nations had systems of writing young and old, unlimited and with. glyphs, and leiters. Several hai out cost, must be the principal various modes of perpetuating ideas. means of future national happiness Benj. Frankila, Jk.

$$
\text { 3. PHILOLOGY: }
$$

Dirs Lotter to Mr. Caspirolion, on the Araphic syetems of Americu, and the Glyph of 0

You have become celebrated by decyphering, at tast, the glyphs and characters of the ancient Eigyptians which all your learned predecessors had deemed a riddle, and pronounc had deemed a riddle, and pronounc announced your discovery in a let-

ter. I am going to follow your footteps on another continent, and a theme equally obscure; to none but yourself can I address with more propriety, letters on \&. subject so much alike in purpose and import ance, and co similur to your own la bours.

I chall not enter at present into any very elaborate discussion. I hall merely detail in a concise manner, the object and result of $m y$ inquiries, sn as to assert my claim a do the kind of in a philological and historical point Clinese glyphs introduced under of riew; which was announced as Yong-ching, and used also by many early as 1828 in some journals, (3 nations of Africa. latters to Mr. M.Culloh on the Ame-

4. 'There were acveral such graphic aystems in America to express

deas; all of which find equivalents the east continent.

5. They may be ranged in twelve series, proceeding from the most simple to the most complex.

1st Series.-Pictured aymbols or glyphs of the Toltecas, Aztecas, Huaztecas, Skeres, Panos, \&c. Similar to the first symbols of the Chinese, invented by Tien-hoang before the flood, and earliest Bgyptian glyphs.

2d Series,-Outlines of figures or abridged symbols and glyphs, expressing words or idesa; used by almost all the nations of North and Sirnilur to the second kind of Egypian symbols, and the Tortoige letters brought to China by the Longma (dragon and horse) nation of barbarous horsemen, under Sui-gin. $3 d$ Series.-Quipos or knots on trings used by the Peruvisns and

4th Series. -Wampums or atringa 
not properiy it. ull development ume, like that of tian antiquities. perhaps at some

a to prefix the as guides to $\mathrm{my}$ Its of $\mathrm{my}$ iuqui-

een the land of those made in or less vain

18 were equal in on, and sciences rica and Europe; en of the Asiatio at no American of writing. Several had rotuating ideas. veral such granerica to express find equivalents nt.

canged in twelve from the most complex. tured symbols or itecas, Aztecas, Panos, \&ce. Simbols of the Chimbols of the Chi-
Cien-hosng before orliest Egyptian

ines of figures or and glyphs, exideas; used by ins of North and on the most rude. id kind of Egyphe Tortoise letoa by the Longhorge) nation of h, under Sui-gin. bos or knots on - Peruvians and h American nahe third kind of troduced under sed also by many

mpums or string of thells and beads, used by many Simllar to the syllablc alphabets of nations of North America. Similar Aaia, Africa, anil Polynesia.

to those used by some ancient or 10th Series.-Alphabets or grarucle natiuns in all the parts of the phic letters expressing simple world, as tokens of ideas. sth Series.-Runic glyphs or Fouml in many inscriptions, medala, marks and notches on twigs ur lines, and cuins in North and South Ame. used by several nations of North rica, and Iately introduced every Amarica. Consimilur to the runic where by the Curopean colouists. Amarica. Consimilur to the runic where by the Curopean colo.ints.
glyplis of the Celtic and Teutonic Similar to the alplabets of $A$ sia, Afnations.

6th Series, - lunic marks and dots 11 th Series - Abreviations or let. or graphic aymbols, not on strings ters standing for whole worls, or nor lines, but in rows; expressing part of a glyph and graphic delinea. words or ideas; used by the ancient tion, staniling and expressing the nations of North America and Mex. whole. Used by almost all the ico, the 'Talegas, $\Lambda z$ tecas, Natchez, writing nations of North and South Powhatans, Tuscaroras, \&cc. and aleo America, as well as Asia, Europe, the Muhizcss of South America. and Africa.

Similar to the ancient symbols of 12th Series.-Numeric syatem of the Etruscans, Euyptians, Celts, \&c. graphic signs, to express numbers. and the Ho-tu of the Chinese, in- All the various kinds of signs, such vented by Trang-hies called also as dots, lines, strokes, circles, glyphs, the Ko-teu-chu letters, which were letters, \&c. used by some nations of in use in China till 827 before our North and South Americs, as well era.

as in the esstern continent. as in the esstern continent. 7th Series,-Alphabetical sym- In my next letter I shall chiefly bols, expressing syllables or sounds; gruups disposed in rows; such is the the most curious and least known of graphic syatem of the monuments of the American modes of expressing Otolum, near Palenque, the Ameri- and perpetuating ideas. I shall give can Thebes. Consimilar to the a figure of a sample of those monugroups of alphabetical symbols used mental symbols, with comparative by the ancient Iybians, Egyptians, figures of two alphabets of Africa, Persians, and also the last graphic the nearest related to them, and aystem of the Chinese, called Ven. where the elements may be traced, tze, invented by Ise-koang. which are grouped in those glyphs.

8th Series.-Cursive symbols in which some years ago, the Eociety of groups, and the groups in parallel Geography, of Paris, offered a large rows. derived from the last, (which premium for a voyage to Gustimala, are chiefly monumental,) and used and a new eurvey of the antiquities in the manuscripts of the Mayans, of Yucatan and Chisps. cluietly those Guatimalans, \&c. Consimilar to the fifteen miles from. Palenque, which actual cursive Clinese, some demo- are wrongly called by that name. I tic Egyptian and many moditications have restored to them the true name of ancient graphic alphabets, group- of Otolum, which is yet the name of ing the letters or syllables.

9th Series.-Syllabic letters ex- ins. I should have bcen inclioed to pressing syllables, not simplesounds, undertake this voyage and explora. and disposed in rows. Such is the tion myself, if the civil discords of late syllabic alphabet of the Chero- the country did not forbid it. My kis, and many graphic inscriptions attention was drawn forcibly to this found in North and South America. lsubject 28 soon as the account of 


\section{6}

those ruins, survesell by Capt. Del beyond conception, and cannot be Rio as early as 1787, but withheld reduced to order. This misconcepfroun the public eye by Spain, was tion arose from a superficial published in 1822 in English.

knowledge of the matter, and

'This account, which partly de- wish to agsert extraordinary things. scribes the ruins of a stone ci.y 75 If the same wish hal been evinced miles in circuit, (lenæth 32 Enulish respecting Kurope, they could have miles, greatest brcadth 12 miles, ) found 60 languages and nations in full of palaces, monuments, stutues, France, and 100 in Italy, by consiand inscriptions; one of the earliest dering the various provincial French seats of American civilization, about and Italian Dialects, as so many lanequal to 'Thebes of Erypt; was well guages, since many of them cannot calculatel to inspire me with hopes be unilerstood by the respective that they would throw a great light provincials of the same country. over American history, when inore And éach provincial group would properly examined.

I have been disappointer in finding that no traveller has dared to penetrate ayain to that recondite place, and illustrate all the ruins, monuments, with the languages yet spoken all around. The society of Geography has received many additional accounts derived from documents preserved in Mexico; but they have not been deemed worthy of the reward offered for a new survey, and have not even been published. The same has happened with Tiahuanaco in Bolivia and $S$. America, another mass of ancient ruins and mine of historical knowledge, which no late traveller has vieited nor described.

Being therefore without hope of any apeedy accession to our knowlerige of those places, I have been compelled to work upon the mate rials now extant, which have happily enabled me to do a great deal, notwithstanding all their defects, and throw soine light on that part of the history of Anerica. C. S. Rafinesque,

Philadelphia, January, 1832.

\section{AMERICAN HISTORY.}

be a nation, since languages distinguish nations.

Even Balbi, after reducing the 1500 or 1800 supposed Aunerican languager and tribes to 422 , has not attempted to class them except geographically. I made the attempt ever since 1824 in the Cincinnati Literary Gazette, and have since corrected my classiñcation, reducing the 1800 American Dialects to about 25 Generic languages, which belong to the original nations of America, many of which have yet is much affinity as the Latin and Greek, or English and German.

They are the following, 14 froin North and 11 from South America.

1. Languages and Nations of North America.

1. Uskit, divided irto about 30 Dialects and tribes; such as Bsquimaux, Mmuts, Chugach, Aleutian, Chuchi, \&c. spoken all over Boreal America, from Bering strait and Alaska to Labrador and Groenland. 2. ONGuY, about 50 dialects and tribes; Hurun, Onondaga, Seneca, Hochelaga, Tuscorora, Notoway, \&cc. extending from the Pucific ucean to Canada and Carolina.

3. LeNar, nearly 250 dialects and Tabular View of the American tribes; such as Chinuc, Dinneh, Generic Languages, and Ori- Algic, Shawan, Miami, Micmac, ginal Nations.

Orie of the most glaring errors of speculative philosophers on the sub ject of America, is to be found in their assertion that American lanMogn, Nantico, Powhatan, \&c. extending from the Columbia river on the Pacific ocean to Hudson bay, New England and Florida.

guages and nations are multiplied and tribes; Atnah, Chopunish, 
nd cannot be is misconcepa superficial natter, and a dinary things. been evinced ey could have ind nations in taly, by consivincial French as so imany lanof them cannot the respective same country. group would languages disreducing the osed American to 422 , has ss them except ade the attempt the Cincinnat ind have since icatinn, reduccan Dialects to nguages, which inal nations of which have yet the Latin and ad German. owing, 14 from South America $d$ Nations of nerica.

1 into about 30 - such as Esquiagach, Aleutian all over Boreal ring strait and - and Groenland. 50 dialects and ondaga, Seneca, rora, Notoway, oin the Pucific id Carolina. 250 dialects and Slinuc, Dinneh, Liani, Micmac, Powhatan, \&cc. e Columbia river sean to Hudson and Florida. bout 60 dialects ah, Chopunish,
Coluch, Chingita, \&c. spoken from/dialects and tribes; such as Haytian, California to latitude 55 in the north Cuban, Yucayan, Eyeri, Cairi, West Arara, Cumana, Arayas, Arugoas.

5. SkreH above 125 dialects 8 c. extending from the islands of

5. Skrer, aure Seris, Pakis, Bahama and Cuba, to Coro, Cuand tribes; Panis, Seris, Pakis, Bahama ard Cuba, to Corc

Jepan, Shoshoni, Opata, Uchis, inana, Guyana and brizil. dialects Poyay, dc. extending from Slaves, Galibi, Yaoy,

a, and trilies; Carib, Gaivas, Gotos, Chay and Honduras.

6. Nacнгz, nearly 75 dialects mas, Gutacas, \&c. spread lrom the and tribes; Cado, Yatasih, Wocon, Carib islands to Durien, Otonuco, Cuza Cataba, \&c. extending fiom Guyana and Brazil.

Sinalos in the West to Carolina in 17. Purıs, about 90 dialects and Sinaloa in the West to Carolina in tribes; Maypuris, Achaguas, Coropis,

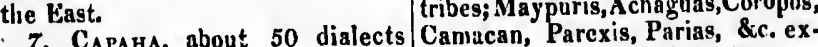
7. Cronoco actending to Brazil and Paraguay.

Ochagra, Dacnta, \&c. extending from the head of Missouri river to 18. YanunA, about 25 dialects the Wabash and Arkanzas rivers. and tribes; Betoy, Ayrico, Ele, 8. Coroa, \&ce spread from the river Oronoco and tribes; Cricasio Seminole, \&c. to the river Parana and Popayan. Humah, Muskolgih, Seminole, \&c. to the river Parana and Popayan.
extending from Fexas to Florida. Cuns, about 25 dialects and extenuling from Texas to Florida. 19 . Cuns, about 25 dialects and ribes, Talle- nacuna, Cloco, Cocinas, \&c. spread tribes; Trum Panama to Coro and. Popayan. gha, Talahuicas, Talahasi, \&c. frum Panama to Coro and. Popayan. extending from the Alleghany 20. MAYsa, about 60 dialects and mountains to the inountains of tribes; Yameos, Mmaonos, Manoa,

10. Atalan, about and tribes; Tula or Tarasca, and Quito to the Maranon and Mutalan, Tulan, Tecas, 'Tulban, Parana.

Colima, Tarahumara, \&c. extending 21. MAcs, about 100 dialects from New Mexico to Michuacan, and tribes; Muhizca, Yuncas, Zafrom Nicaragua. 11. Oromi, about 20 dialects and Tao, Pinoco, Chaco, \&c. spreading tribes; Miges, Dotani, Mazahuy, throughout South America front \&c. extending from Arkanzas to Cundinamarca to Peru aud Brazil. ac. extending from Ar. Gurani, nearly 300 dialects Mexico.
22. Guarani, nearly soo dialects
and tribes; 'Tupi, Omagua, Cocsma, 12. Azrrc, about 20 dialects and and tribes; Tupi, Omagua, Cocsma,
Tayarea, \&c. spread

Pipil, \&cc. extending from Mexico throughout Brazil, and from the to Nicaragua.

13. MAYA, about 40 dialects and south as Buenos Ayres. tribes; Huazteca, Poconchi, Guichi, 23. Maras, abuut 50 diamaru, Yucatan and Guatimala. $\quad$ Muras, Marahas, Andua, Moratas, 14. Chontaz, abiut 50 dialects Zapibo, Cuyaba, \&c. spreal from and tribes; 'Izendal, Choles, Locas, Peru in the west to Brazil in the Lencas, Zoques, Quelen, Chiapan, east on both sides the Equator. \&c. extending from Chiap to 24. Lute, about 2.5 dialects and \&cc. exteniling from Chiapa to tribes; Vilela, Mocobi, Abipon, 2. Lunguages and Nations of I'oba, Atalala, \&cc. spread through Sorth America. Clitaco, Tucuman anil Paraguay.

I5. Anuao, having nealy 100 25. Chru, about 20 dialects and 
tribes; Puelche, Chonos, Araucan, conspicuous and civilized. Their Tehuelet, Yacanac, Kemenet, \&c. true name was Atalans. They spread all over Austral $\Lambda$ merica may have been the founders of from Chili to Magelania and Fuego Orouvm and many other ancient islands.

cities. Their descendants exist to

Kiven these 25 Languages and this day in America, under the Origina! Nations unay perhaps be names of 'Talas or Tarascas, Atareduced to 18 by more accurate lalas, Matalans, Talegawis, Otalis investigation; this the 4th and 5th or 'Tsulukis, 'Talahuicas, Chontalas may become united; as well as 6 and or 'Tsendalas, \&cc. from Carolina to 8,7 and 11,9 and 10 , as they have Guatimala.

considerable analogies. The same When Columbus discovered may happen in South America with again America, he and the earliest 15,16 and 19, also with 17,18 and explurers were struck with the 20, which approximate by gradual similarity between many American dialects. C. S. Rafinesqur. similarity between many American
tribes, and the Guanches of the Juily $4 t h, 1829$.

Canary islands, remains of the

Reinirk.-The above was pub- Oceanic Atlantes, in features, manlished in the Evening Post; it is now ners and speech. Whether the reprinted because it is the key to Haytians, Cubans, and Aruacs were American Ethnology, Philology and genuıne Atlantes is rather doubtful, History! The proofs would fill because their language is more akin voluines. It is results that analyti- to the Pelagic than the Atlantic. cal Science 3 chiefly require. The But three at lenst out of the twentywide extenc of Nations 1, 2, 3, 12, five original nations of America $15,16,2 \mathrm{k}$, were already acknow- above enumerated may safely be ledged: $t$ '心 others depend on my deemed children of the Atlantes. researches, and are open yet to They are the ninth or Otalis, the many improvements, nay; 1 have tenth or Atalans, and the fourteenth effected some since 1829 . or Chontals.

5. Tre Atrantro Nations of Ame- ways, and by their languages com. rica. By C. S. Rafinesque. pared with those of their African

The Ocean separating Europe brethren, Tuarics, Guanches, \&c. and Africa from America is yet after a separation of nearly 5000 called the Atlantic ocean, ourlitoral yeais. But the proofs would fill a states are called the Atlantic states. volume.

The Atlantes of North Africa who Ouractual Cherokis and akin tribes gave their name to the Atlas are the children of the first branch, mountains, and whose descendants named Otalis. This was their oriexist there as yet under the names ginal name. Adair only 100 years of Tuarics, Berbers, Shelluh, ago says that the genuine or upland Showial, \&c. were one of the primi- Cherokis were called Otalis, which tive nation of both continents. name meant mountaineers as in They came to America soon after Africa. They call themselves now the flool, sf not before, colonised Tsulukis. Our name of Cherokis is and named the Ocean and the derived from the worl Chelakis, islands in it, as well as America, name of a tribe. They have not the which was" called the Gnest sound of $R$ in their speech. Only Axuantis, or ratlier ATALA, one tribe substitutes $R$ to $L$. The meaning the first or main land. interesting history of this nation This name is preserved in Hindu shalldeserve our attention hereafter. traditions. The Atlantes were The Chontal branch or nation not the only primitive colonists will come under- notice in investiof America; but they were the most lgating the antiquities of. Otolum 


\section{8}

ized. Their ans. They founders of ther ancient ants exist to under the rascas, Atasawis, Otalis ts, Chontalas Carolina to discovered the earliest c with the 1) American ches of the ins of the atures, manWhether the Aruacs were her doubtful, is more akin e Atlantic. i the twentyof America y safely be he Atlantes. - Otalis, the ie fourteenth ed in many guages comeir African lanches, \&c. nearly 5000 would fill a

ad akin tribes first branch, as their orily 100 years ne or upland talis, which peers as in mselves now f Cherokis is rll Chelakis, have not the eech. Only to $L$ The this nation on hereafter. in nation in investi. of Otolium or Paleoque. It remains here to Greek. It admits of all the Greek survey the genuine branch of rhetorical figures. The plural in ATAcuns, eldest perhaps of the formed by $X$. It has nearly all the American Atlantes. yet hardly known) are the Tarascas three sibilant TS, TZ, and TZH.

of Michuacan in West Mexico: The analogies with the Italian are the brave nation that first asserted striking in the following phrases, and the late Mexican Independence. snme even appear with the Saxon Their true name is TALA, and English.

TALA, S, CA, meaning Tala, self, English. Tala. Italian. the or in our idiom the veryself 1. Thou Thu Tu Tala. They have no $R$ in their 2.Was (wast) Bsca Sei (fosti) speech, and this name was changed 3 . Thou who Thuqui Tu che by the Othomis and Mexicans into 4. Spoke Vandahaca Favelasti Tanasos8. See grammar of their language by Basalenque, Mexico, 1 . 1714.

$\begin{array}{lll}\text { 1. I } & \text { Hi } & \text { Io } \\ \text { 2. Was } & \text { Hasca } & \text { Sei (fui) } \\ \text { 3. I who Hiquinini lo che }\end{array}$

Hrom this interesting little work,

the Sparish writers we leater,

the Spanish writers we learn some-

thing of their language which is yet 1 . Is not Noxas Non $\mathbf{B}$

apoken and may be thoroughly 2. So wise Mimixcti Amico (savio)

studied. We also learn that they 3. As I Isqui hi Com'io

formed a powerful and civilized The following vocabulary of 85

kingdom independent of Mexico at words, gives a fair sample of the the Spanish Invasion, which became language. The affinities with the the ally of the Spaniarda; but was Pelagic and its children, Greek, Laby them, subdued by treachery and tin, Etruscan, and Italian, are mark. infamous conduct. But we learn ed by the letter $\mathbf{P}$; those with the very little of their previous history: Atlantic dialects of Africa, with the and the little known is buried in letter $A$. They amount to 50 out antranglated Spanish books. It of 25 with the Pelegic, or 60 per is by their language that we can cent. of analogy; and to 33 out of 65 hope to trace their origin and most with the Atlantic, or 51 per cent. remote history.: Languages do not Theae are striking facts, deserving lie, suys Horne Tonke. They reveal atlention, in spite of the unbelief of what time has buried in oblivion. some ignorant or lazy philosophers

We shall therefore give some ac- or historians, who neglect or disbecount of it, that the learned or cu- lieve these evident proofo. The sirrious may atudy its affinities. So teen Engligh affinities are marked far as we have done so already, we by an asterisk. The orthograpliy is, have been struck with its evident of course, Spanish.

analogy with the Atlantic, Coptic, English. Tala.

Pelngic, Greek, Latin, and Italian Water Ama, Ma. A.P.

langugges of Africa anil Europe, both Fire $\mathbf{P a}$.Vepo, Tani. A.

$\begin{array}{l}\text { in words and structure, in spite of a } \\ \text { separation of four or five thousand }\end{array}$ "Iand $\left.\begin{array}{l}\text { Haca, Eche, } \\ \text { Andatze. }\end{array}\right\}$ A.P.

separation of four or five thousanil

years.

This language is rich, beautiful,

and highly complex. It aimalgamatee rarticles to modify the words, as in Italian. The verbs have fifteen

modifications, as in Italian, or near-

ly vo; they can be compounded as in "Mountain

Tyacapu,

Tzacapu,, A.P.

Cuiri. A.

Pueclia.P.

Marin. P.

Vichu. A.

Vata. A 


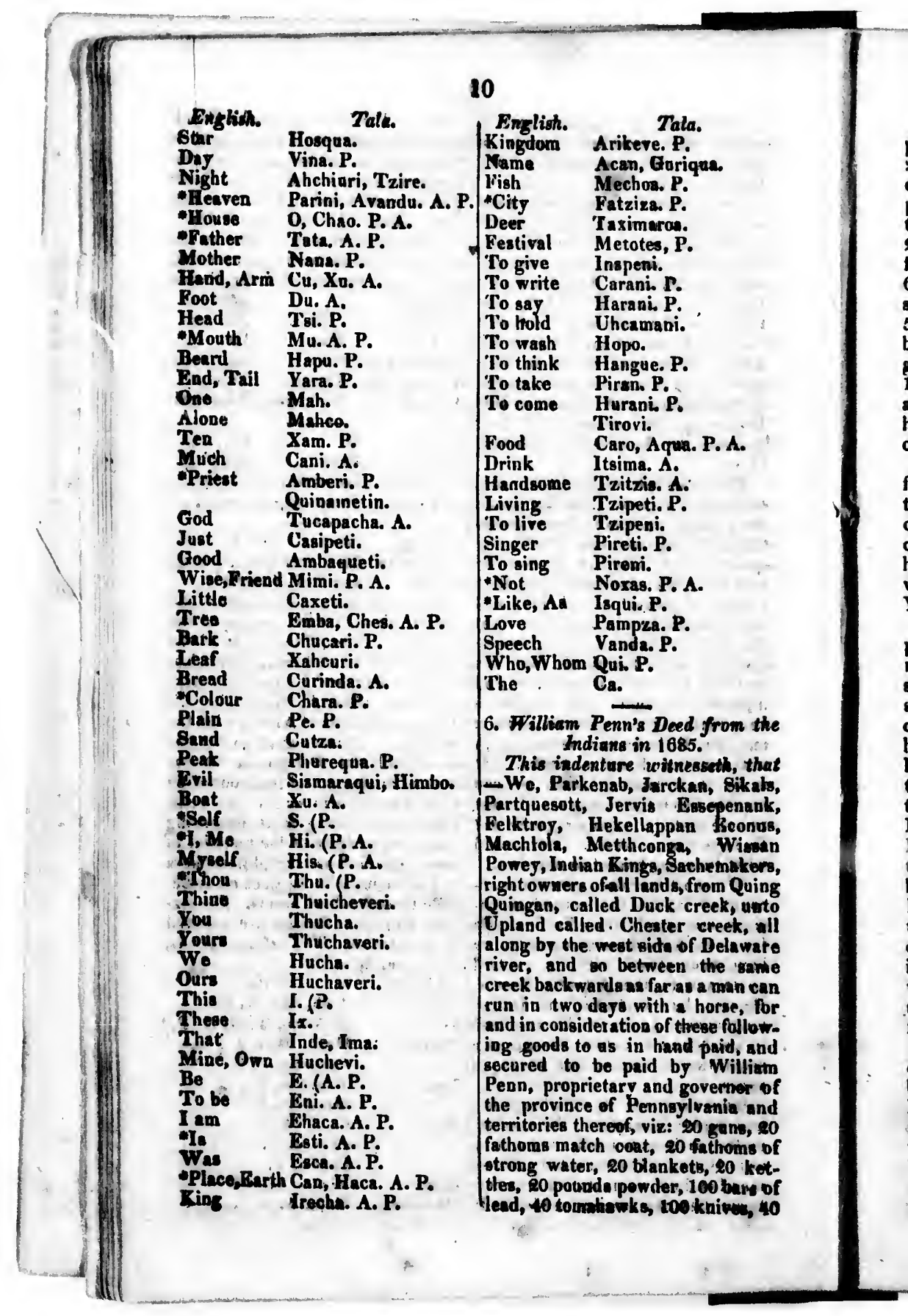


pair of otockings, 1 barrel of beer, good in a court of lan of equity. 20 pounds of red lead, 100 fathoms It is chiefly of wampum, 30 glass bottles, 30 tion of the articles given, some use. pewter spoons, $100 \mathrm{awl}$ blades, 300 ful and some useless, like the Jews tobacco pipes, 100 hands of tobacco, harps. We strangly suspect that 20 tobacco tongs, 20 steels, 300 this deed alludes merely to the first flints, s0 pair of scissars, 30 combs, presents made by the worthy $W$. 60 looking glasses, 200 needles, 1 Penn to procure the good will of the skipple of salt, 30 pounds of sugar, Indians, and has since been ooa5 gullons of molasses, 20 tobaccu strugd into a sale of the whale terboxes, 100 Jews harps, 20 hoes, 20 ritory of these Lenap Indians, of gimblets, 30 wonden screw boxes, whom Parkenab must have been the 100 string of besds-Do hereby great sachem. It is well known acknuwledge, \&cc. Given under our that at a second treaty held at hsnds, \&c. at New-Castle, 2d day Shackaniaxon, now Kensington, anof the Eighth month, 1685.

The above is a true copy taken made. The subsequent history of from the original by. Ephraim Mor- Pennsylvania after Penn', afford ton, now living in Washington many instances of injustice to the county, Pennsylvania, formerly a friendly Lenaps. clerk in the land office, which copy he gave to $W \mathrm{~m}$. Hutton, and from which the above is taken in Little York, this 7 th of December, 1813. Hemarks.-Tho above deed co. tions ond tables of the Gemesee pied from the Ephemeral Press, is Farmer for 1831 .

not yet recorded in history; but de. 'Rochester is : the most thriving serves to be. It was the first in- town in the western part of the stance of a colonist having bought a great state of New York. It is sitcountry from an Buropean king, who uated at the interaection of the Gehad no more right to it than the nesee River and Great Erie Canal king of the moon, buying agein from near the falls of the Genesee and the real owners of it It is the first not far from Lake Ontario, towards title deed of the great state of latitude 43.

Penneylvania. Yet the good $W$. The extremes of temperature Penn did not pay the full value to were 95 degrees on the $3 d$ Jnne. the 10 igaorant Indian Chiefs, and and 4 below 0 on the 7 th February his example has been closely fol- Difference 99 degrees; medium 45 . lowed to this day. He bought by degrees. The highest medium wae that deed about 2000 square miles in September 61 degreses, the lown. of good land for about \$300, which est December 10 degrees. "The is now worth as many millions, and mesn atmospheric pressure was was then worth at least 810 the 29 degrees 51 minutes.

square mile iustead of 15 cents psid The number of rain days were for it.

15 and 27 inches of angere

Yet this deed is not explicit July alone 5 inches. As many as onough, at least as it was printed, 66 snowy days were noted with 76 because it does not state how much inches of snow fahen, in all the land was cerled and solil, unless months of the year except June. they sold their whole domain froin July, August, and Septeinber. The the Delaware to the Susquehannah prevailing winds west, south-west, between Duck creek and Chester north-west. It is noticed that the creek, anil the sale be implied by temperature of epring waler varie the Eve. \&uc., or not 'printed. We from 40 to 60 degrees, maline doubt whether this doed woald be (therwforo 50 degrees. 
This mean heat of 50 degrees in sunrise, there has been found a springs and range of 99 degrees, is great difference of many degreea of an additional proof that the interiur warmth in favour of Rocheater, alof this continent is warmer than though it is 480 feet above the sea, the coast and has a lesser range of lat. 4310 , and Albany at tide water variation, an usual concomitunt ef. in lat. 4235 .

fect. Since Portgmuuth in New 1831. Albany. Rochester. Diff. Ilampehire on the Atlantic and the aame parallel of $\mathbf{4 3}$ degrees as Rochester, has a mean temperature of 44 and range of 110 . Whible

Detroit in Michigan, still farther weat and also near 43 degrees, has 501 mean hent, with a range of 116. It muat be added that Rochester and Detroit are both much above the level of the ocean and ought therefore to be colder on a par.

Parallel of 43 degrees latitude.

1. Portamouth, level of the sea 44 degrees mean liest, range of 110 degrees.

2. Hocheater, 480 feet above the cea, 45 inean heat of the air, 50 of the springs, range 99.

3. Detroit, 565 feet above the sea, 501 mean heat; range $116 ?$ is this right?

It is probable that the increase of mean heat and smaller range, is gradual all the way from the At. lantic to the Pacific ocean; where a difference of 12 degrees at least in equivalent temperature and range is found. There the 52 degree of latitude being equal to the $\mathbf{4 0}$ degree, near Philadelphia or as warm.

The 52 degrees of Europe is also equal to the 40 in China, the ehstern part of each continent being colder.

But the different yeara often give variable results: thus this year, 1832. the winter has been very severe all orer North America. The river phis from the beginning of December to the iniddle of Pebruary, which had not happened for nearly 40 years. In Rochester it is stated that the winter has been more se. vere than for $\$ 0$ years past in the Cenesee country. By compara. tive observations inade at Albany and Rocheater in Decomber last, at 9 th $2^{\circ}$ do. $18^{\circ}$ do. $20^{\circ}$ 10th $8^{\circ}$ do. $14^{\circ}$ do. $22^{\circ}$

This is an additionsl complete prnof that the climate improves inand.

The Genesee Country of which Rnchester is the metropolis, extends froin Pennsylvania or lat. 42 , to Lake Ontario in lat. $43 \frac{1}{2}$. It contains about 4000 square miles of fruitful soil. The staples are wheat, averaging 20 bushels to the acre, and maize averaging 40 bushels. The mear heat of the vegetating season is 60 degrees.

\section{AGRICULTURE.}

Results of the iExperiments of Rzoluz on the Fixed Oils.

This article is one of those of practical Sciences, which belong at once to many, being connected with Agriculture, Gardening, Chemistry, Economy and Materia medica: this enhances their value.

Fixed Oils of Vegetablea are of the utmost importance and use for food, light, cooking, soap, machisery, manufactures, and medicines. It was very needful, to ascertain exactly what quautity was afforded by each vegetable, so as to knnw the most profitable to cultivate, and cheapest to use; this las been done by Recluz, a French chemist, and we give here the analysis of his bours.

All the experiments were made upon one pound of the substance, or 7680 grains weight, and the quentity of oil afforded is stated in ounees.

Aluonds $7 \frac{1}{8}$ ounces.

Hemp aeed $3 \frac{1}{2}$ ounces.

Cocos 4 ounces.

Olives $3 t$ ounces, specific weight 0915, forms sulid soap. 
ten found a iy degrees of locheater, albove the sea, at tide water

chester. Difi. $5^{\circ}$ ab. $0 \quad 19 \circ$ $8^{\circ}$ do. $20^{\circ}$ $4^{\circ}$ do. $28^{\circ}$ nal complete improves in-

try of which polis, extends ir lat. 42 , to 43t. It coniniles of les are wheat, to the acre, 40 bushels. 1e regetating

TURE.

periments of ixed Oils.

of those of which belons ng connected rdening, CheMateria medir value.

retables are of e and use for ap,machimery hedicines. It ascertain exas afforded by to know the ultivate, and las been done chemist, and halygis of his s were mado. subatance, or subatance, or d in ounees. $\therefore$ pecific weight
Popps seed 4 oz. specific weight United States we might make an im0922 forms liquid sosp. Arachis or groundnut 8 ounces, most oily substances common with fine eatable oil, citron colour, keeps us. Groundnuts, pumpkin seeds, well and maken good soap. sunflower seeds, hazlenuts, walSesamum or Benny seed 31 oz. nuts, beechnuts, \&c. for all the needfine sweet oil, limpirl and autrient, ful purposes of salals, cooking, but becomes easily rancil. burning in lamps, soap naking, \&c.

Pumpkin seed $5+$ ounces, sweet if industry was nut palsied by oil, nut siccative.

Cornus berries, 4 ounces. $\quad$ Mr. Recluz has omitted the cot-

Muringa, or Ben oil, 6 oz. white, ton seeds, which affird nearly 50

concrete, made by heat, smells per cent. of good burning oil, and 80

like noyau.

Euphorbia lathyrus seeds, 8 make millions of gallons of it in the ounces by ether, 7 by cold ex- south, and - gell it to profit at 25 pression; medical purgative. cents the gallon. His experiments

Croton tiglium seeds 9 ounces, on the Sessmum are at variance green, drastic. Helianthus or Sunfiower 6 oz. Benny seed has afiorded 80 to 90 sapid sweet oil.

Cyperus esculentus roots $3 \mathrm{oz}$.

Datura seeds 21 ounces, medical. His experimento on volatile oila, Grape ceds $1 \frac{1}{2}$ ounces, by boil- will be noticed hereafter. C. S. R. ing.

Ricinus or Castor oil, 5 to 6 9. Confirmation of the Important ounces made cold, 7 ounces warm, Discovery of the property of 12 ounces with shelled seeds. Sulphun in raxks, to destroy all Sassafras seeda 21 ounces white Insects preying on them.

oil, medical.

Farmers and Gardeners ought to Beech nuts 6 to 7 ounces, sweet, hail with rapture a safe, certain, clear, inodorous; gets getter by easy and unfailing mode of drivings age to the reverse of other oils. away or destroying all the insecta; Xanthium or Burr seed, 41 bugs, caterpillars, lice, ants, which ounces, aweet oil; gives a fine clear prey upon trees and often kill light. $"$.

Flax seed 31 ounces, yellow Numberless have been the means brown, siccative, feticl. proposed or devised to get rid of

Walnuts 8 ounces, lemon colour these truublenome guests, most of oil, thick, sicentive, makes a soft which aredirty,costly, or unavailing. soap, gives 12 ounces when nuts Our farmers appear to have given. dried in ovens.

Pine seeds (Pinus pinea, P. the deadly attacks of curculios nn cembra) 5 nz. sweet oil of good the roots of peach trees, and the flavour, good to eat. Almonds of stone fruits, plumbs, efficaciuus mode is said to have been peaches, Ec. 3 ounces. $\quad$ found several years ago in Prance, Mustard seerls 31 oz. yellow, perfectly efficscious and applicable aweet, odorous, good soap. The man

Laorus or Baytree beriries 71 who discovered it, leserved ounces green oil, the seeds 1 in splendid reward, yet his name has ounces of concrete greenish oil. 2 not even reached us. But we clnim

Hazlenuts 7 ounces, oweet thin the honor to have been the first' lemon oil. : to make known the procese in

Thus it will appear that in the America, in 1823 in Kentucky, and 
in 182: in Philadelphia. Yet the most useful knowledge is so slow to spreal, that the fact is hardly known yet, or duubted by those who know of it.

We are happy to be able tn publish two direct experiments in support of the finct and liscovery.

First. We bored und plugged with auphur in the usual way, a plumb tree which commonly llropped every year all the plumbs before becuming ripe, the curculios lodging eggs in their germs. 'Ihis was done when the tree was in blossoun. On that year hardly any fruit fell, and the tree produced quite well.

Secund. We hind in the Genesee Fariner of January 28, 1832, that a young willow nearly killed by aphis or lice, and pissmires feeding on their honey, was quite revived in three days, and all the lice and ants driven off, by horing the tree with an augur five feet from the ground and three-fourths through the diameter, filling with brimstone and plugging tight. The tree has thrived ever since.

The modus operandi of this singular process is very easy to expluin. The vital energy of the tree and sap, dissolves the sulphur, carries it into circulation, and evolves it in sulphuric gas evaporating through all the pores of gas is a desdly poison to ine smell of the Melissa. A few plants are found or ought to be found in every $\mathrm{good}$ drives them away as soon as they garden. It grows with the utinost begin, to smell it; but no injory facility from seeds and in any coil. whatever results to the tree.

Being perennial it lasts many years We have never heard yet of any without nny care, not even requirdirect experiment on peach trees; ing watering. 'The whole plant is but we are sure it will answer quite scented and has a peculiar gratefal as well. if the sulphuric eimana- strong smell between lemon and tien could not reach quick enuugh munurda : which is produced by tho the routs of the trees which ore essential oil of the glands: This commonly attacked: the pluggin's fine volatile oil nay be obtained by must be done near the root or at distillation, but only one pound is the time of the desceoding sisp, produced by 800 pounds of the when it will soonor resch the roots. fresh plant. It swims on water and Wet it be tried and the reiults is colourless, but becomes yellow by mide known.

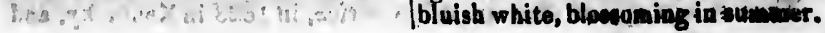


JLTURE.

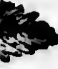

(2)
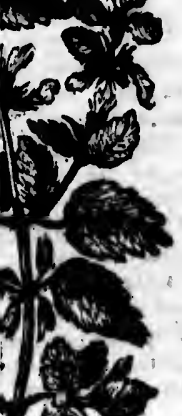

on $\mathbf{B}$

the figare of ono of plants, both fraThe Commion d from Europe ; but ild in Virginia and species very near it. se fine smell of so tants are found cound in every good ws with the utinost and in any eoit. 1 it lasts menly years re, not even requirThe whole plant is - a peculiar gratefal atween lemon and between lemon and the glands. This may be obtained by thay be oblesing $t$ only one poend is 800 pounils of the Awima on water and ut becomes yellow by at beco rers are sniall, hubles.
In medical properties this plant/considered in a different point of is similar to many of the labiate view.

plants ; being one of the inost grate- My Classes Plantarum are but ful it is often usetl, making a fra- outlines: I have been far fioun deeingrant tee and pleasant distilled wa- ing thein perfect. I consiler it a ter, vehicle for many inedicaunents. great lionour and alvantage to enter The tea and water are gentle diffu. into currespondence with you, since sible stimulants, antispasmolic, ex- you labour on the same subjects. I pectorant, pellent, resolvent, \&cc.; shall be ylad to profit of vour ilisco. they are useful in all obstructions, veries. But 1 cunnot agree witl hysterics, headache, pilea, pleurisy, you on the numerical accurilance of asthma, cholic, palay, several fevers classes in Animals anil Plants. It chiefly nervous, \&ec. Another beau- appears clifficnlt that the animals tiful aative plant not uncommun in whose variable form depend on the our gardens, the Monarda Coccinea, metlium of their existence, sud their Scarlet Balm or Oswego tea, is an notions, food, \&c. may ugree witl equivalent that may be used when the classes of plants. But I suapend the common balm is lacking; but al- my judgment until I see your clasthough stronger in effects, it is not sification, when I shs II communicate quite 80 grateful. .

This plant grows one or two feet that the positive characters can only high, with square stem and branch- belong to artificial groups of beings; es. Leaves opposite petiolate ovate natural groups can only have tenacute sierrate. Flowers oxillary in dencies, since there are few immuhalf whorls, pedunculate, with ob. table characlers.

long bracts.

My new theory of VegetationconIt is the moral emblem of Grate- aists in proving that there are but - folness. Metiene, lovely nymph and grateful plant, plants: Tho gandep sides apd shady groves adorna, 1. Leaves or appendicular organe. And feeting smeet by gratitude evolr'd; But thos Aneng the sected th wes of labialt brooms The Grat perbars: to modent onvolinew clad, selves under six different forms: Not dazzitiag colons nor gigantic size; $\quad$ I. Cotyledons and plumule. By sencle maids belored and foeling hearts.

$$
\text { 11. BOTANY. }
$$

$\begin{array}{ll} & \text { 4. Pract and flower-bud. }\end{array}$

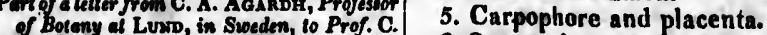

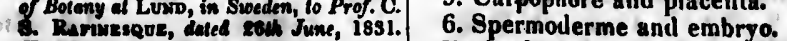
Trondelat from in French.

$T$ hare published, since 1825 , be: a degree of regetation, or an age of sides many Memoirs inserted in the it. Wach flower that has sereral Literary Transactions, two pam-petals, or a dividect corolla and caphlets on a new theory of Vegetable lyx, consists of as many flosculea. Thyeiology in French, and the $V e$ - $\Lambda$ decandrous flower ouly differs setable Organography in Swedish from a pentandrous, because the inand German. I am now publishing ternal floscules or petal a are sterile a Vegetable Biology, based upon this or without stamens: The applicanew theory. As soon as this shall tion of this theury is immense. You be pablished, I mean to andertake will see it in my work. It would the Natural Bystem, on a plan more be well to translate my organograealarged and correct than in $m y$ phy in English, that it may be expreviems dphorisms, asd my Classes amined and studied by the English Plantionsen: according to the new Botanists, that do not rearl German. Phyoiological syatem, all will be Remarke by C.S. R.-The thove 
16

fragment on Rotany is Intereating; near cuneate, entire; branchleto unithis new theory of $A_{\text {garth }}$ is cer- lateral; flowers sessile, lax or remote. tainly nn improvement on the actual Arit hills of Kentucky, one to three belief of many eminent Botanists, inches.

that all the urgans of regetations 5. Polygonum squamosum, Raf. ere mere inodified furms of the leal, disc. 18i8. Stem diffuse; leaves variously unfulded, separated, or smootli, obtuse, linear longer than solilererl. Both, however, appear internudes; stipules scariose, acumitoo aystematical, and the roots, nate, lacerate, elongate, equal to in. stems, fruits, \&ce. do not appear to ternodes; flowers solitary, axillary, be essily reclucible to these notions. sessile. From West Kentucky, an That positive characters do belong nual, aection octandrous, estival. or ought to belong to each naturai 6. Pulygonum hyssopifulium, Raf. group of animale and plants, is to disc. 1818. Stem erect, slender, rame as evident as day-light: the op- mose, atriate; leaven las, remote, onsite opinion han been the great linear, elongate, acute; stipules in atumbling block to the beautifui na- cylindrical sheaths, end setose or tural mothod of Botany, and a great ciliate; raceınes filiform; flowers re. hiadrance to its general adoption. mote, often binate or ternate. Lower Unleas we admit thia, there will be Ohio, annual? one foot. 8. G. PCPno line of demarkation between a sicaria.

man and a monkey, a dog and a cat a rose anil a blackberry, an oak anc chesnut tree.

7.Urtica gracilis, Rat. disc. 1818

Stem smouth, slender, yellowish, with four furrows; leaves opposite, remote and amall, petiolate, lanceo2. Selection of twenty-four out of late, trinervate, serrate, acuminate one hundred new species of Plants and smooth; capitules of flowers axof North America, sent to Europe illary, pedicellate, geminate, form-

in 1828 , by C. S. Rativesque.

1. Anychia Polygonoides, Rar discovered, 1818. Stem dichoto mous, lax; erect, puberulent; leaven patent, linear cuneate, acute, nearly amooth, atipules lanceolate; flower colitary in dichotomy, subpedicellate, erect. From the mountains Alleghany, and estival like the three following, six inches high.

2. Anychia fastiginta, Raf. disc. 18iqu. Stem dwartish, erect, puberulerit, subdichotome, fastigiatc; leaves ailpressed, linear cuneate acute; fowers crowded, fastigiate, secund, aubsessile. Prom Kentuc$k y$, one or two inches.

S. Anychia conferta, Raf. disc. 1821. Steun erect, dichotume, puberulent; leaves linear cuneate acute, serrulate; flowers crowded fastigiate, bracteate, pedunculate From knobs of Kentucky, annual three or four inches.

whorl of four, shorter than petioles. From Kentucky, annual, estival, one or two feet high.

8. Uitica verna, Raf. Jisc. 1882.

Difiers from the last, by leavesorate, acute, not acuminate; flower axillary and subspicate; capitules nearly sessile, opposite. Kentucky, in

wooda: vernal, annual, one or two feet.

9. Monarda riglda, Raf. disc. 1818. Stem tiff, mugh, hirsute eaves sessile, ovate, nearly obtuse; tifi; ciliate, subserrate; capitule pedunculate, involucre pentaphyllous, lanceolate, ciliate, acute; as long as fowers; corolla smooth, apex of apper lip villose. In West Kentucky. hilly barrens, perennial, two or three feet high, flowers flesh coloured. 10. Scutellarin radicata, Kaf. disc. 1818. Runt annual, very loogs stem snall, ramuse; leaves on long petioles, ovate, ciliate, obtuse; unall. 4. Anychia lateralis, Raf. disc. broadly aerrate: flowers terminal 1821. Stem procumbent, dichotome, axillary, large, pubescent. On rive diváricato: lenves remote, short, li- Oohio, three to six inclies, dificre from 
branchlets uniile, lax or remote. cky, one to three squamosum, Raf. diffuse ; leaves - diffuse; ger than acariose, ncumirate, equal to in. solitary, axillary, solitary, asillary, est Kentucky, a yssopifolium, Raf erect, slender, $\mathrm{ra}$. vies lax, remote, acute; stipules in ths end setose or iliforms finwers res. or ternate. Lower or fout. S. G. Perilis, Rat. disc. 1818. lender, yellowish, us ; leaves opposite, II, petivlate, lanceoserrate, acuminate ser itules of flowers four, shorter than Kentuck , annual, two feet high.

twa, Raf. disc. 1882. last, by leaves ovate, minate; flowero axilcate; capitules nearls ite. Kentucky, in annual, one or two a rigida, Raf. diac. tiff, rough, hirsute; ovate, nearly obtuse, ibserrate; capitule poolucre pentaphyllous, acte; iate, acuth, apex of up- In. Weat Kentucky, perennial, two or three pers fiesh coloured. ric redicata, Raf. disc. annusl, very loogs stom 2 leaves on long peticiliate, obtuse, amall ciliate, terminal ate : flowers terminal, e, pubescent. On river e, pix inclies, diliere from
Sc. parulfiora, by leaves petiolate the Olilo river, three or four feet high, and flowers four times as large. flowers greyish, estival.

11. Scutellaria villosn, Raf. disc. 17. Eupatorium rupestre, Raf. 1818. Stem erect, simple, hairy; disc. 1821 . Stems crect, simple, leave: petiolate, ovate, obtuse, cre-- striate, white, villose; leaves opponate, hairy; raceme bracteate, brne- site, sessile, lanceulate, acute at both teas obovate, flowers opposite. In- ends, trinervate, rough, of a yellowdiana and Kentucky, woods; flowers ish glaucous colour; corymb fastigiwhitish, one foot high, estival, pe. ate, foliose; perianthe sliort, oblong, rennial? differs from Sc. ovalifolia, 5 flore; scales oblong, obtuse, pubesby leaves crenate and bracteas. cent, external ovate nblong. On

12. Sarothra cuneijolia, Raf. disc. the cliffis of the river Kentucky, one 1821. Differs frum S. canndense or or two feet high, flowers whitish, esstricta, (Hypericum canadense, I.) tival. Near to $E$. slaucescens of by leaves cuneate, linear, obtuse, Elliot.

luwer obovate; flowers four times as 18. Aster hyssopifolius, Raf. disc. large; calyx ovate; petals cuncnte, 1818 . Jueaves sessile, aclpressed, twice as long as calyx. Kentucky, linear, acute, one nerved, entire, estival, one foot.

13. Viburnum macrodon, Raf. ers large, pedunculate; perianthe disc. 1818. Branches tetrsgone; lax; scales cuneate, scariose at the leaves opposite, petivlate, smooth, base. In lllinois, one or two feet, but petiole and nerves pubescent, flowers blue.

large round, base oblique, subcor- 19. Prenanthes rubida, Raf. disc. date, margin with large teetl]; cyme 1822. Glabrous; stem striate, rupedunculate, pubescent. Mountains bicund; radical leaves petiolate, 1 Alleghany, shrab four feet high, ver- rate; last lobe trilobe, unequally annal, white blossoms.

14. Galium setaceum, Raf. disc. sessile, lanceolate; flowers fascicu1818. Stem erect, diffuse, rough : late, pendulous, red outside. Cumleaves by six, cuneate, linear, mu- berland mountains and East Kencronate, rough backwards on the tucky, two feet high, autumnal. edge: panicule lax, capillary: fruits 20. Helianthus tenellus, Raf. disc: smooth, pedunculate. Illinois, flow. 1822. Stem simple, uniflore, anguers white, near to G. asprellum. lar; leaves opposite, petiolate, ovate

15. Eupalorium serratum, Raf. lanceolate, acuminate, remote, aerdisc. 1825. Stem erect, sinıle, rate, trinervate, tender, roughish; rough, striate: leaves opposite, re. flower peduncle rough, perianthe mote, sessile, rough, ovate, uninerve, lax, linear; rays few, elongate. acute, broadly serrate; corymb re- Mountains, hills of East Kentucky, gular, pubescent; bracteoles linear; two or three feet high, flowers yelinternal perianthe 5 phyllous, lun. low, autumnal.

ceolate, striate, 5 flore. On Poto- 21. Helianthus striatus, Rat. disc. mack, Virginia, two feet high, flow- 1818. Stem erect, striate, pauciers white, estival. flore; leaves opposite or aiternate,

16. Eupatorium pectinatum, or petiolate, lancenlate, acuminate, enE. lungipes, Raf. disc. 1818. Stem tire, above rough, with white dots, erect, branched, striate, rough; beneath subtomentose. Hills of leaves opposite on long petioles, Kentucky, two or thrce feet, flowers ovate lanceolate, base abruptly acute pale yellow, estival.

end grailually acute, sharply serrate, 22. Sisyrinchium albidum, Raf. trinerve smooth; corymb unequal, disc. 1822. Leaves striate, narrow, fastigiate; perianthe 8.10 flore, few eejual to scape; scape winged, wings scales, oblong, obtuse, hairy. On/striated, unabel multiflore, spathe 
unequally 4 valved, pedicels erect; animals are known to range very corols white, obcordate, mucronate; far in search of prey.

capsules globose. In West Ken- Several instances of liuge beasts tucky, flowers vernal, scapo four to having been seen in Louisiana, six inches, slender; one valve of the Arkailzas, and Kentucky could be opathe very long, rigid; three very collected by enquiries among old omall, acariose.

collected by entjuiries among old
liunters. When seen at a distance

23. Scirpus typhinus, Raf. disc. only, they are commonly mistaken

1804. Leafless; scape compressed, for large l'anthers, our unspotted striated; spike terminal, cylindrical; Couguar. When seen too near, the acales ovate elliptic, obtuse, con- boldeat liunters are afraid of them. cave, amooth, rufous, with scariose When shot, nobody knows them, margin. Pennsylvania hills, one or not even the Indians; and the skins two feet.

are soluhigh at once for sids-saddlea.

24. Scirpus nudus, Kaf. disc. 1804. Sometimes the account gets into Differs from the last by actpo slen- some newspaper, but is usually disder, not otriate; opike amall, cllipti- believed or 800 n furgotten.

cal; scales ovate, acute, scariose. lieved or 800 n furgotten. Virginia, amall, hardly a foot high. only mentions that the Jagaar or Muny other interesting plants Felis onza of the naturalists wander were sent in this century, which sometimes east of the Mississippi, may be noticed hereafters auch as Lechea linifolia and paucifolia. Juncus falcatus.

which must be crossed by swim. ming. This animal comes as far north as Kentucky in lat. 38.

Neottia montana and gracilis. Tradescantia rupestris.

Melanthium longifolium.

Collinsia purpurea.

Plantago gonophylla, \&cc. \&cc.

While I was in Kentucky I heard of several having been seen and shot. Two of them, a male and female, did once make a stand near Russelville, and alärï many travellers, feeding on hoge, until a party of huntera went in pursuit 13. ZOOLOGY.

On the large uandering Tyoers or JaOuars of the United States. Bj C. S. Rirswequz. a way the other.

on the 6th of June, 1820, by $\mathrm{Mr}$ The Jaguars are the spotted Juln Six, on Green River, 10 miles Tygers of America, found from south-east of Hartford, in Ohio Mexico to Paraguay. It was sup- county. The skin was brought to posed that none were ever seen Frankfort and an account given in further nurth or with us; they are the papers. This animal appeared hardly mentioned in our Zoological to bea true Mexican Jaguar. The booka, and their casual visits dis- body was 5 feet lung and the tail believed by many when they hear 2 feet. It weighed 150 pounds beof them. But Humbuldt has lately fore skinniag. The back and sides ascertained that the atriped Tyger were yellow with black apots curiof - India, often wanders to the ously arranged in several rows, a north as far as Tartary and Siberia. row on the back much larger and 1 will - prove that the apotted extending over half of the tail, Jsguars do the same in America, which was rather slender, with very and wander as far as Kentucky long hair at the end. Chin, and Lake Erie in latitude 42. This belly, and feet white, ears small always happens in summer, and is round black outside, white inside. not at all extraordinary, since our Whiskers stiff 6 inches long, black summers are as warm as in the with the end white.

tropics, and these carnivorous But anotlier Jaguar atill larger 
to range very

f huge beasts Iouisians, ucky could be cs among old at distance tonly mistaken our unspotted en too near, tlie afrsid of thein. knows them. s; and the skins lor sid s-saddles. sount gets into t is usually disgotten. tuna Americana $t$ the Jaguar or turaliats wander the Mississippi, ossed by awim. al coines as far ky in lat. 38 entucky I heard been seen and em, a male and ake a stand near alärm̈ many traon hogs, until a went in pursuit one, and drove

ther had been shot ne, 1820 , by Mr. en River, 10 miles entord, in Ohio in was brought to account given in animal appeared ican Jaguar. The lung and the tail ied 150 pounds beThe back and sides h black spots curlin several rows, a - much larger and half of the tail r slender, with very the end. Chin white, ears smal tside, white inside 3 inches long, black hite.

Jaguar atill larger
2. Var. Fintlrely grey: Green

and of a different apccies has lately been seen as far as Lake Erie, and lat. 12. One was shot by the 3. Var. Fallow; outside of the Seneca Indinns, to whom it was toe ears, feet and end of the tail black. tally unknown, another was killed boily four feet, tail ucarly three. in the Alleghany mountainsof Penn- Scen in Kentucky.

sylvania, and an account given in 4. Var. Back nearly black, sides the papers. These nimals were dark reddish brown, feet black, body totally distinct from the common six fect, tail three feet, legs very Jaguars they must have been short, only one foot long. In New wanderers from New Mexico or the Hampshire. Dr. Moose.

Oregon mountains, and belong pro. 5. Var. Differ from the last by bably to a new apecies. which I pro- body five and a half feet, tail two pose to call Felis dorsilis, owing to and a half fect, feet twenty to twenthe black band on the back. There ty-two inches long, called Pennsylare several other species of Jaguars vania Couguar by Button. Allein South America, little known or ghany mountains. Theso two last not well diatinguished.

Specific characters, Fur.1s Don- species.

als, Dorsal Jaguar. Of a grey The Couguars being spread from colour, neck fallow, a black line or Canada to Chili, or 90 degrees of band all along the middle of the latitude, must vary in their fur. back, two rows of ringed apots on Every traveller gives a difierent each side, black above, brown bclow. account of them, or calls their fur Total length 10 feet including the by a different name, black, brown; tail, body 61 , tail st. Very differ- red, rusty, fallow, sallow, Jellow, ent from Felis pardalis by size four grey, \&c. They may yet belong times larger, neck and back, \&c. all to a single species; but these varieties or deviations must be 14. On the North American Cou- noticed, as they are in man, the guars. By C. S. R.

The unspotted Tygers, or Lions without mane, of America have been called Couguars from the Guarani 15. Extracts from A Second Series There are several varieties of them of Zoological Letters written to in North and South America, not Banow Cuvieu of Paris, by Prof: well known as $\mathrm{sct}$; in South America they are rerl or black, 1831. - I sent in 1821 to Paris, a species. In North America, fallow memoir on fifteen Trilobites of or grey. All these are called North America, and published in Felis concolor by the zoologists and Lexington the new $G$. Inoctomesa deemed identic. This may be of that family, which Dr. Dekay doubted; we know too little of these has since erroneously called Octoanimals to decide; as they are be- meris; there is a $G$. Octomeris, coming scarce it is needful to pre- already among shells; $\mathrm{my} \mathrm{Sp}$. was gerve the knowledge of those vet however different from his, being extant. The following are on re- emarginated behind, and one of the cerd or have fallen under my notice. largest Trilobite known, being nine They are called Panther, Painter, inches long. It was preserved in and Catamount in the United the Cabinet of the University. Btates. They winter with us. There are also some very small 1. Var. Yellowish, $8 \frac{1}{2}$ feet longe Trilobites nearly like the EntoIn Carolina. Dr. Mease. 


\section{0}

wrocera, without eyes, of whlch 1 aend jou the figure.

diagonally on the sides. Tail tri-

I have found in Lake Eric, in lobes short obtuse, middle lobe long 1826, two N. G. very near to the cylindrical. Spec. C. fulvescent, Trilobites, both lacustral living wrinkles equal in length but not animals: both without antens and in depth, inside smooth flled with with concealed feet. I call them a yellowish liquid.

Pcltoma with two eres, and ide- The second Geonema rordinea, lopus without eyes. I send you the was" a subterranian Gordius found figures. Also the description and two feet under ground in Connactifigure of another living sea N. G. cut, with body fliform, fistular, from the atlantic shore between filled with a fluid, elastic, the two Idoten and $\mathrm{m}$ Gonotus of $\mathbf{1 8 1 4}$. call it Mesotropis albipes. Body oblong, back carinated, small head, no eyes, fourteen feet, tail with many articles and ciliated, two antens, $\mathbf{S p}$. Car. greenish-brown, hoth ends obtuse, antens equal to body and tail, feet white.

$I$ send you the figure and de ecription of a singular atlantic smal sea shell, Nemalix pelagiea, which suspends itself by a thread from the Fucus natan in the middle of the ocean, discovered 1815.

I send you, as you request, the figure, description, and a specimen of $\mathrm{my}$ Trinectes Scabra, a new G. of his near to Achirus found in the river Schuylkill; it has only three fins, dorsal, anal and caudal. Also the description and figure of a large and beautiful new catfish from the river Tennessee discovered in 1823, Pimelodus lutescens: it was three feet loing, excellent to eat, of a olivaceous yellow colour, belly white, jaws equal, eyes round, tail forked, first dorsal falciform, second dorsal nearly as large as the anal.

Extracts from letter 2, April, 1831. I send you the figure and description of two subterranean worms. The first Ophelmis rugosa, is near to Gordius, but dwells under common alware destitute of mouths, and therefore living by absorbing their nourishment by the ground in 1817, and was preserved minnte pores of the body: whereby in a museum. It was a gigantic they belong to the peculiar clase or worm, almost like a snake, three division of animals nearest to plents, feet long. Gen. C. body fistular and merely differing by their sponta. compressed, leathery, without vis- neous motions, which $\mathbf{I}$ called Po. cera, not annulated but wrinkled/nosrouss as early as 1814 in my 
Tail tririor, lateral dle lobe long - fulvescent, th but not filled with ma gordinea, iordius found in Connectiorm, fistular, astic, the two ted, opening, Description. both ends oblong.

- but aquatic ind by me in a r Hudson in m Gordius by head split or I call it iia. Length a violin string, fulvous brown te bilobe, tail white tip. been the first observed and copical animals s, poole, creeks, the ocean, in in Kentucky, Sicily. and the is is quite a new beings, fecund They swrarn - from a size 86 seen without a ower, sometimes 8 smaller than a a size visible to l even reaching a e ocean; where I ot long, al though the moist minute, alwaye destitute erefore living by suriahment by the 10 body: whereby - peculiar clase or nearest to plants, ng by their spontacalled Po1y as 1814 in $\mathrm{my}$
Somiology, and illustratel in my/wonder how Lamark pat them Analygis of Nature in 1815. This among animals. It was probibly name is very good, but if not agree- like the Porostomes, Corallines, anil able to all, I have-half a dozen Spunges upon a mere surmise of others to offer as substitutes: Bio- animality. But I defy any naturalpores, or Zoopores, or Leptremes, or ist to perceive any mution in them, Adelostomes, \&rc. Because it is my or to find out their pulyps or wish that this class or large section mouths.

of animals should bear a good name I send you the figures and de. given by me,'instead of the delusory scriptions of ten N. G. of aquatic one of Animalcula or microscopic porostomes, whici will demonstrate animals, which does not apply to the variety of size and form. I all.

Besides it is very probable that the gigantic Aproctomus of Sicily, many other, if not all the animals and in 1825 the large Scalenium of without mouths, must belong to this the ocean.

class; such as the mouthless 1. Stigoma tripunctata. Ocean.

Meduses, the Tethya, Alcyons and one inch, cuneate flat, head obliSpunges; perhaps some Oscillatoria quely bilobe, tail mucronate, three and Confervee. These porostome dots on the back.

animals are generally aquatic and 2. Lobuloma inequalis. Ocean, floating: but there are some fixed one line, flat with six unequal lobes ones also. Others are parasitical on the maryin.

(like - many worms) living in other 3. Thalanema capitata. Ocean, animals. Some may be terrestrial two inches, filiform flexuose like like the Geonema above. The Mias- Vibrio, but one end enlaryed oboval mata or miasmic animalcula of the obtuse.

air, may be the invisible birds of this 4. Zoocoilon levis. Sicily, half class, or aerial insects floating in the inch, subglobular, truncate, witi a air. This may appear a bold surmise, large cavity occupying the whole but it is not prepusterous, they ha hardly been seen yet, but are perfectly well indicated already. Lastly ther are aloo fossil on in animals of this class. They must 6. Diplepha gibbosa. Lake have existed abunduntly in the Erie, half line, oblung sinuose, primitive earth; and some of those gibbose, two pairs of geminate with a cartilaginous orleathery body bristles, a fifth at one end.

have been fossilizeri. My fine N. 7. Disynema isella. Kentucky, G. Trianisites of 1818 may be one, pools, microscopic. Two threads also $\mathrm{my}$ N. G. Bolactites, Geodites, united at both ends, like a conGranulites, Tractinites, \&c. dis- ferva, but with free motion. covered in the oldest geological 8. Blobula varians. Kentucky, strata of Kentucky, and united infusory. Oblong sinuate, one end protem to the Alcyonitea. Some with five bristles, the other with may also have been akin to the one.

actial Mullipores of the sea, which 9. Pecticoma paradoxa. Kent. are real stong plants and not ani- infus. oblong sinuate, ciliated bemals: having no motion whatever, neath, bristles unequal three lonest, being fixed, without mouths nor one in the middle and another at viscera; no polyps about them: a each end.

mere vegetative concretion of the 10. Lonsoma incurva. Kent. insea with minute pores. Some na- fus. oblong turalists even deem them a kind of a curved knife, the two endo aoute, marine stalagmites. We may well one raised up, no organs. 
I senil you also the figures and tory of the earth and mankind, bedescriptions of five new fishes No. 3 fore and after the great peological to 7 . Zonipus punctatus, Semotilus notarus, Lepeniurus fusciolatus and bilineatus, Luxilus auratilus and Zonargyra virescents. All observed in the wsters of Kentucky since publishing my Ichthyology of the Ohio in 1820, except the Lepemiurus.

$$
\text { To be Continued. }
$$

16. Description of the Spelerpes or Salamander of the caves of Kentucky. By C.S. RAFinesque.

In 18211 discovered a new Sala. mander, dwelling permanently in the dark caves of limestone near Lexington. It never comes out to the light, being found there in summer. Its eyes are calculated for this

life: they are large elliptical, with a large black pupil like the cats to shade them from the least access of light. It is called Cave Puppet in Kentucky, while the other Salamanders are named Ground Puppeta. Several specinens were preserved in the Museum of the Lexington University, presented by Dr. Crockatt.

It appears to form a peculiar $\mathbf{N}$. G. or S.G. among the Salamanders,

which I call Spelerpes, meaning Cave reptite. Head round, brosd and fat;mouth very large,split to the neck, jaws with small teeth, obtuse in the upper jaw, acute in the lower. Feet semi-palmated, anterior with four toes, hinder with five toes. Tail cylindrical, slightly compressed at the base. Fyes oblong with a pupil.

$$
\text { pupil. }
$$

Spelerpes lucifusa. Entirely orange colour, covered with smali oblong black dots all over, jaws equal. Tail very long, five eighths
of whole length, which is from four to six Inches.

loods, which have desolated the globe, are highly interesting; they belong at once to geology, archeoloy, history and many other sciences. They are the only glimpse to guide us where the fossil remains or medals of nature are silent or unknown.

Ancient China was in the eastern slopes and branches of the mountains of Central Asia, the hoary Imalaya, where it is as yet.very doubtful whether the flood thoroughy cxtended. The traditional history of China speaks of two great floods, which desolated but did not verwhelm the land. They answer to the two floorls of Noah and Peleg recorded in the Bible, which happened towards 3170 , and 2357 beore our era, and have often been erroneously blended into one by several historians. The second or flood of Peler, or Yao in China, w88 caused by volcanic paroxysms all over the earth, and much less fatal than the first of Noah, or Yn-ti in China.

The following details are taken chicfly from the Chinese historians $L o-p i$ and $L i u-j u$, whose works are called $\boldsymbol{Y}$-tse and $U a i-k i$, as partly translated by Leroux. Due allowance must be made for the allegorical and amplifying traditions; but truth may be sifted from them. The Chinese have few fables in their history; they deal in facto rather than fictions.

The first flood of China happened under the 8 th KI or period called $\boldsymbol{Y} n-t i$, and the first emperor of it, Chin-sang about 3170 years before Christ, or 5002 years ago: The waters overflowed the land, and did return to their usual channels kind was extreme, the beasts and 17. GEOLOGY AND HISTORY. serpents were very numerous, the History of China before the flood. storms and cold had increased with By C. 3. R heavy raing. Chin-sang collected

The traditions presented by many the wandering men, taught them to ancient nations of the carliest his- unite to kill the beasts, dress their 
sind, beeological ited the ng; they r, archether sciglimpse 1 remains silent or the eastof the 6 , the hoayet. very thoroughional histwo great it did not ey answer and Peleg hich lap2357 beften been 0 one by second or China, was xysms all less fatal or Yn-ti in are taken historians works are , as partly Due allowhe allegorilitions; but rom them. fables in a in facts happened riod called peror of it ears before ago. The and, and did al channels ery of man. beasts and merous, the reased with is collected ght them to dress their skins for clothlng, and to weave religion of Adam, Noah, and the their fur into webs and caps. He Patriarchs.

was venerated for these benefits, Chao-kang-tse, of the JU reliand began a SHI or dynasty that gion, has established that the world lasted 350 years, or perhaps reign. is to last 129,600 years, or a period ed 550 moons, equal to 27 years. called -1 uen, composed of 12 equal

The two words KI and SHI, parts of 10,800 years called Huei or translated Period, and Dynasty or conjunctions, of which the half or family, are of some inportance; they 64,800 years were elapsed at Yac may have other collateral meanings, towards 2357, years before Christ. and require a philological examina- In the first Hoci, the 'Tai-ki or tion. As they now stand translated, Supreme Being formel the Heavens they would make the world very old; by degrees, and by giving a motion since no less than $10 \mathrm{KI}$ or periods to chaotic matter. In the second are enumerated (we are in the 10th) Hoei, the earth was produced in the wherein 232 SIII or dynasties of same manner. Men and animals Emperors are said to have ruled in in the third, \&c. The 10 last Hoei China, during a course of 276,480 answering to the $10 \mathrm{KI}$, but in a difyears before Christ, at the lowest ferent chronology.

computation, or $96,962,220$ years Lopi and the most learned histobefore Christ, at the highest, with rians place at the beginning of things many intermediary calculations by Hoen-cun, or the chaos, and Puanvarious authors. But if $\mathrm{KI}$ may al- $c u$, meaning remote antiquity. Af80 mean a dynasty or division or peo- ter which begin the three first $\mathrm{KI}$. ple, as it appears to do in some in- which are collectively called Sanstances, and SHI an age, or a tribe, hoang, and commonly put down as or a reign; the whole preposterous successive periods or dynasties; but computations will fall, or be easily there are in my opinion nany intrinreducible, so as to agree with those sic proofs that they were contenpoof the Hindus, Persians and Egyp- rary. The principal is that they tians.

are somctimes called SHI as well

There are now three principal reli- as $\mathrm{KI}$.

gions in China, each having pecu- 1. Tien-hoang, meaning Celestiliar notions on the Creation, and al Emperors, the very title yet of the early history, \&cc. as every religion emperors of China. They must have elsewhere. 1. The $J u$-kiu, religion been the real primitive rulerg of of the learned and worslip of an- mankind in Thibet and Western cestors. 2. Tao-kiu, or worship of China on the mountains: where the spirits, a kind of Shamanism. 3. Fo- early history of the Ilindus places a kiu, or the worship of $\mathrm{FO}$, a kind of race of Heaveuly kings, and the land Budhism. . All the diversity of itself was called Heavenly or Ceopinions on those subjects found in lestial. The rulers had many other various Chinese books, are owing to titles, Tien-lino or Celestial Inthis. The various opinions and their telligence, Chong-tien-hoang-kun concordance has never beell proper- meaning Midllle-Heaven-Emperorly attempted; yet it must be re- Supreme, \&c. To them is ascribed membered that these three religions the discovery of pictured letters and. are in fact mere branches of the pri- books, with the rudiments of Astromitive religion of China, the TAN nomy. The 18000 years of their as. religion or worship of Heaven upon cribed duration, may safely be re hills as altars, of which the empe- duced to 1384 years, by reckoning rors were pontiffs; somewhat like each year for a moon, as moons Judaism, Christianity and Maho- were the only primitive years, evmetanism are in the western regions, ery where. the three branches of the primitivel 2. Ti-loang meaning Earthly. 
Emperors, lasted also 18000 years successors. These $U$-long had five or nioons, 1384 of our years: which families or divisions, they were is an additional proof of cun-barbarians, dwelling in caves and temporary duration. They are said on trees. This could not be if they to have been sons of the Celestial had been successors of the civilized Fimperurs, and fathers of the next GIN.

KI, all of which are sometimes per- . Of the fourth, fifth, and sixth sonified. They must have been the KI very little is said. Lopi asprimitive rulers of the Lowlands cribes 90,000 yeara duration to which were called Earth in oppo- them including the $U$-long, which sition to the Celestial Mountains. if reduced to moons, would still To them is ascribed the discuvery amount to 6923 years, a very long of the sular year of 12 months of 30 period; but it is very probable that days, making the year of $\mathbf{3 6 0}$ days, they were partly contemporary is it was before the flood.

with the San-hoang, and some of

3. Gin-hoang meaning Human the barbaruus branches of mankind, Emperors were nine brothers, sons of since they dwelt in caves, rather the Ti-hoang, wlio divided the earth than towns. 'I'heir names were among them, and built cities surrounded with walls, foundeci kingdoms and settled governments, be- of the Lolo tribes of south-west coming despotic rulers, while before mountains of Clina")

or among the other two KI, the 5th. Lien-tong, six families or rulers were only patriarchs. Their tribes.

duration is extenderl to 45,606 years, $6 / h$. Su-ming, four families or which if reduced to moons, would tribes.

be only $\$ 503$ years. These GIN or The signification of their names men appear to be the Jins or Ge-- which is inust given, would perhaps nis of the primitive Arabs and Per- trace their connection with other gians, who came in contact with Asiatic Nations. The lost rethem in East Imalaya and Iran, fa- sembles the Samangs and Shamans mous in antediluvian history as of Asia.

good and beneficent heiugs, friends The seventh KI is called Bunof the Peris, the ancient Iranians or fei, and had twenty-two families or Persians.

tribes, of which harlly any thing is

That these TIFN, TI and GIN related, except that under the last were not KI periods, but rather SHI SHI or family Tse she, men were or families of mankind, is evident more civilized, but a flood happened by no Dynasties being numbered whicl began the eighth period of among them. 'They are often col. lectively made a KI named Sanwhicl began the eight

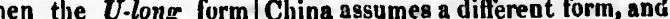
the second KI, while the third has the names of the fanilies, tribes or no oame and therefore no existence. dynasties are given. The subject I rather consiler them as the three shall not be now pursued any first KI, either inpl ying three further; the antediluvian history of periods, or three divisions of man-China alone is here to be illustrated. kind. And I find a fourth division It becomes very prolix as we in the U.I.ONG (sometimes deem- advance. It has been sufficient' to ed a fourth period) meaning Black show and urove that the Chinese Monsters or Dragons, a metaphori- have traditions of the state of the cal name for the primitive Negroes earth before the Hood, as known to of Aria, born in the sandy and them in Eastern Asia, that the sultryregions of Asia, frcm the GIN Asiatic Negroes were sntediluvians, of whom they are deemed sons and and that the deluge of Yao, is not 
gad have hey were caves and $t$ be if they e civilized and sixth Lopi asuration to ong, which ong, which a very long robable that intemporary ind some of of mankind, aves, rather nes were

f three famihe ancestors south-west families or - families or their names vould perhaps $n$ with other he last reand Shamans

called Sunwo families or y any thing is under the last she, men were lood happened ghth period of e. the - history of herm, and nilies, tribes or - The subject pursued any pars history of o be illustrated. prolix as we en sufficient to en the Chinese the state of the cod, as known to Asia, that the Asia, dhavians, of Yao, is not that of Noah as generally aupposed, /aea by overwhelming all the land which to support still more, the SHII between Corea and China.

between $Y$ nti and $Y a o$ are given. The state of mankind before the

The eighth KI or Ynoti harl flood of Ynti (ur Noah, which agrees thirteen SHI or families, all named in time with the seventy conputain history with some details, which tion) is represented as happy. I only deem as many Emperors. China, called Tien-hia or Celestial

The ninth was shen-song with Region, (universe) was ruled by twenty-one SHI, which here turn benevolent monarchs who took out to be 21 Emperors instead of nothing and gave much; sll the families! A convincing proof that world subınitted to their virtues and the previous ones in more obscure goof laws. They wore no crown, times were such also. Here details but long hair; never made war and abound likewise.

The tenth KI or actual period, even reignad between men and opens with the three $H_{\text {oang }}$ or animals; men lived nn roots, fruits August Emperors,called Fuhi, Shin- and cattle, they did not follow nong, and Hoans-ti: to whom great huntiug, property was in common, improvements, discoveries, and acts and universal concord prevailed. are ascribed. Fuhi has been very They did not therefore deserve the gratuitously taken for Noah, by punishment of total destruction by some prejudiced historians, al. a flood.

though no flond happener in his This interesting and important time, and thirty-tive Einperors part of the early history of mankinil. reigned between the flood and him: is not yet inserted in the would. because with him some writers begio be universal histories of the the regular history of China. western Barbarians, as the Chinese After the three Hoang, came the call us. Our compilers for ages $U_{\text {-ti }}$ or five elective Emperors, of appear intent on destroying the which $\operatorname{Yan}$ is the fourth, in whose little remnant of ancient historical time the flood of Peleg, which con- knowledge as yet extant. Let it vulsed the whole globe, was felt in be reviyed.

China during nine years in dreadful I conclude by 3 remaris, $1 \mathrm{Geo-}$ inundations, towards 2357 before logical, 2 Clironological, 3 Philoloour Bra. In 2207 began the II ia gical.

dynasty, the first regular historical 1. The Chinese account of the family. Much obscurity is found flood confirms the geological fact previously, the five Emperors were that the flood was attended with really six, one being soon deposed is chsnge in the year from 360 to 36 . often omitted. The three Augusts days, with a change in the seasons, had each a dynasty often omitted, increase of cold, winds and rainz. the head being only reckoned. The increase of cold hitherto sur-

Fuhi hall fifteen successurs reign- mised, and in which I did harilly being altogether 115 years. ". Shin-nong had seven, dynasty tediluvian Zoology and Botany. lasted 140 years. The increase of wild bessts, who Hoangti dynasty lasted 100 hall probably taken refuge in the years. mountains against the flood, is also

Many other floods are mentioned important. It abows how animals since in Chinese history, as many were preserved as well as men, as aixty-five; but they were ail and does not militate against the local aud did not extend over the Mosaic accnunt, since the worl whole of China, although that of translated ARK in the Bible is 185. before Christ was dreadful, and THEBA, which means refuge, and this or another formed the Yellow lis preserved in Thibet. 
2. Another Chinese book of chro- a large colony was sent from China nology, Li-ta, followed by Morison, to Japan and other Western islands, puts Fuhi, the founder of the Chi- lirom whence they drove the ONI nese Empire in 3369 years before or black devils (negroes) first in. Christ, this would change the whole liabitants of Japan.

series and does not co-oril inate well with Yao, Peleg and the Bible. But the Chinese have various Chro- not given; but it was known to them nological systems as we have. $A s$ and the Japanese at a very early many as 70 have been basell upon period, called by them FU-SHAN, the Bible, reckoning from 4000 to 6600 years from Adam to Jesus Christ.

3. My orthography of the Chinese is the plainest and ghortest I could use, based upon the Latin and Italian, except tluat.SH is like English and CH also as in Church. The Clinese have the French $U$ which I have expressed by UH. The word $U$ (or 00 in Finglish) means Black and Five in old Chinese. The Negroes and the kingdom of $U$ or the Blacks, have existed in South China till 280 before Christ, when they were conquered. It is said that there are even som wild negroes yet in the Mountains ol Kuenlun, probably similar to the Samangs of Malaca.

18. Early Colonization from China by Sea.

Towards the year 2670 before Christ, or 4502 ago under the Emperor Hoangti, ships were invented and built in China, by Kong$\boldsymbol{k} u$ and $\mathrm{Hoa}-\boldsymbol{h u h}$, by orilers froin the Emperor, with hollow trees and furnished with oars. They were sent to discover places beyond sea, hitherto inaccessible and where no man had ever been. Thus the first Chinese Colonies were established in many islands. The magnetic needle had already been invented under Shin-nong about 130 yesrs before, or about 2800 years before Christ.

In 2037 before Chirst, under the Hia dynasty, embassies were sent Hia dynasty, embassies were sent bejond the sea; they came in ships to pay homage to the Hias. In 1197 before Christ, under the far as the lat. $4 \mathrm{~d}$. south of the equator. He Tu dynasty a branch of the Shang, lish his discoveries. history, throw some light over the early history of Polynesia anil America, without proving that the real Chinese ever settled in Ameri. a, where there language is not ound. But the Japanese and Luchus, evident children of old China, speak very difterent languages. China liad formerly and has yet many dialects. The ancient Gins and Tienhias of China before the flood, and the Hias and Shangs ince, may have come and partly colonized America.

19. SCIENTIFIC EXPLORERS IN AMERICA AND AFRICA.

America.-Mr. Auduben is now engaged in exploring the Peninsula of Flarlda, for birds, and to collect animals, as well as all other kinds of natural objects. Ile has two ssistanls with him.

Mr. Drummord, the botanist, has been exploring the Oregon muuntains for two yean. past, chiefly for planis and seeds. He was It is said that he took to St. Louls two tona of paper for pre erving plants.

Mr. Peale is juit returned from hio voynge to South America, and trevels is 1831 up tho R. Magdalcna to Bogota. He bas brought a ne Zoulogienl eclleclion for the Philadelphin Muscum, among which are 500 birds and 50 quadrupeds, which were not there. It is expected that ha will publish ad account of his zoological travels and discoveries. He as-
scrlo the very singular fact that the $\mathbf{R}$. MagdaAfrica.-The mouth of the Niger or Quorra has at last been found by I.ander 10 be as was surmised in the Iarge Delta of Benin, 250 miles broad, end the $\mathbf{R}$. Nun o main mouth. Tha L nokseller Murray has paid him $1000 \mathrm{~g}$ ineas s: the Journal of his iravels.

Douville, a French traveller, has explored Ccago and reachad loland to the N. E. a just returned to Paris where be will pub- 


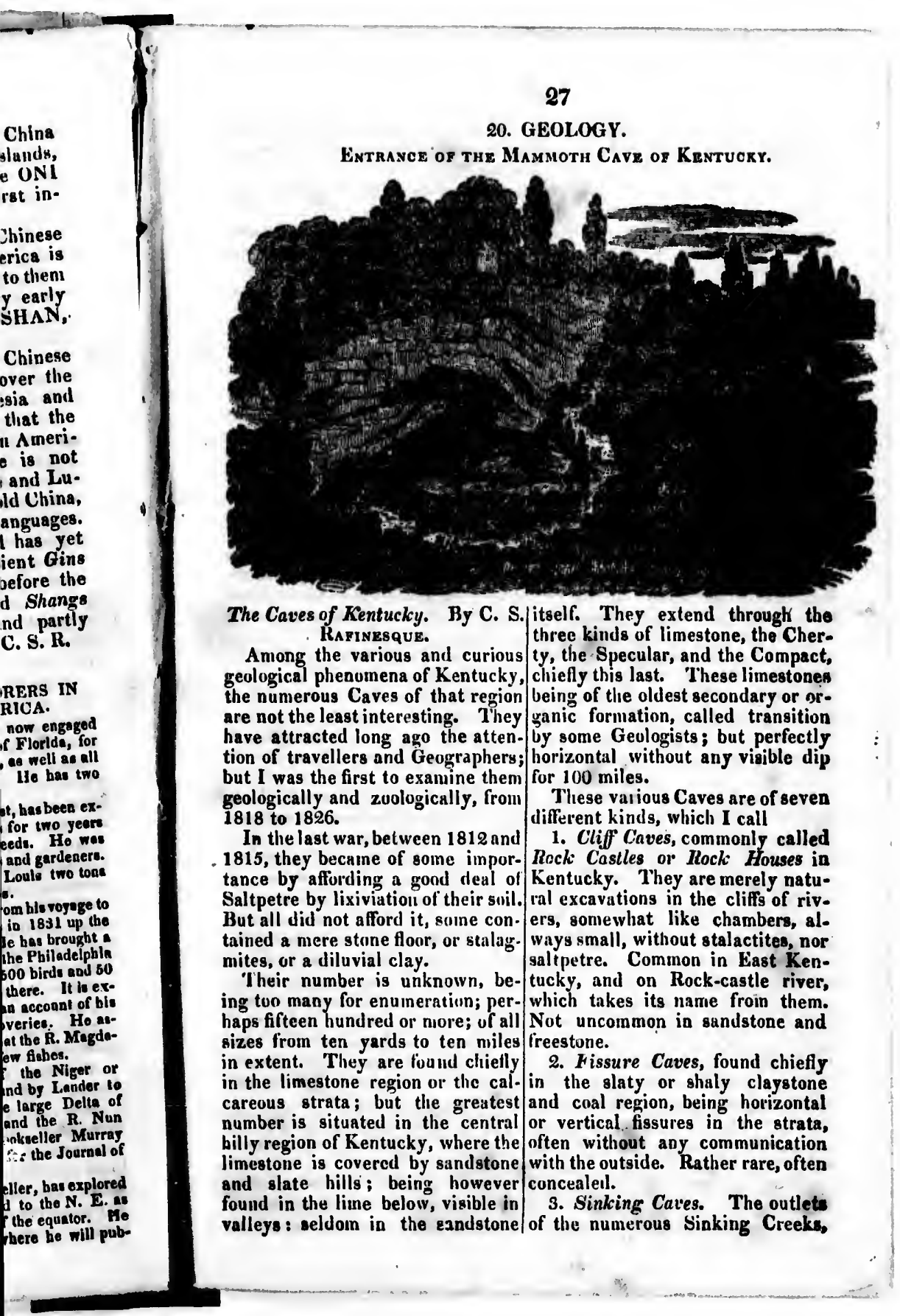


being subterranean channels of The principal fossil bones found creeks and streans, which after a in them, and come to my knowledge, course of 100 yards to one or inore belonged to

miles disappear in thein. 'I'hey 1. T'he Mfegatherium, or an anichiefly differ from the last by hav. ing waters. Conmonly inuccessible, beiug filled by the water. Very cominon, cliefly in West Kentucky, in the open glailes called burrens of the saudstone table lanil.

4. Spring Caves. Giving rise to a streau which issues fron them. either to join another stream, or aink in the Sinking caves. (MI1ly a modification of the last; but less cummuln, sometimes quite accessible, forming vast caverns with vaulted root. Chielly in the limcalone regions.

5. Crater ar Funnel Caves. On Iy in the limestone regions, very comenon, formed by circular or Kentucky, trom twenty yards to one mile in circuit, and from five to fifty feet deep. Sides sloping inside, similar to the craters of volcsnos, but more of a funnel shape, with a vent liole at the bottum, leading to s fissure, spring or cave. When this hole is choked up by earth, the basin fills with water and formy a pond. The sinks sre, according to my eruptive theory of the limestone and clay formations, the springs, craters, or spouts from whence issued in the sea, that ling mud which spread horizontally, imbedding the tossils.

il very near it.

2. My Aulaxiodon speleum, since called Megalonyx laqueatus, by Harlan.

3. A kind of Taurus, eitlıer the Bufialo, or 'I: latif rons.

4. A small animal like \& Polecat. 5. A smaller one yet, perhaps a Sured.

'Tlie animals still living, or rather wintering in thuse caves, where the temperature is very inild and equal, ure bats and rats of many species, and niy subterranean Salsmander, Spelerpes lucifuga, which is perma-

'There slso have been found a few ancient mummies, not antediluvian, but buried in the dilovium, and quite preserved by the antiseptic nitrous soil; they are not numerous, rather accidental than otherwise.

7. The seventh and last kind of caves, are the Stalactical Caves, siinilar to those of Europe, filled with stalactites and pillars, as well as stulagmiten risiug froun the ground. Rather uncoinmon and always in the limestone.

To give a tolerable idea of these caves, 1 shall describe some of them. out of several series.

Jeuning's Spring and Lovedale are two sinking caves of the $3 \mathrm{~d}$ and 4 th Series, between Franklord and

6. Saltpetre Caves. I.arge cavi- Lexington; both in the limestone ties with galleries and chanibers, and shaped like an excavated bow, roof cummonly flat, floor with a rich with a large spring st one end aud uitrous diluvial loan, commonly in a sink at the other. Jenning's spring the linestone. The largest of all is turns a mill, the excavation is 150 the Alammoth Cave, the entrance to yarils long, 3 to 6 wide, and only \& which is figured above, and an ac- or 3 deep. Lovedale could also turn c unt follows beneath. It is in these a mill, but has none. It is rather a that bones of antediluvial quadru- clasin, 200 yards long, 10 wide, and peds have been found. Many were 10 leep.

discovered while digging for salt- Elkhorn Cave belongs to the 4 th petre, but being often crumbling Series; it is in the cliffs of Elkhorn were lost, the best were scattereil creek north of Lexington, like a fine or thrown away, except a few col. hall, with smooth limestone walla. licted by Mr. Juln D. Cliffird and accessible for 100 yards and more, others.

abcut 10 yards wide and high. A 
ones found snowledge, nr an anileum, since jueatue, by either the ie a Pulecat. t, perhapa ing, or rather $e s$, where the Iil and equal, uany opecies, Salamander, ich is perma-

found a few antediluvian, ium, and quite iseptic nitrous wise.

d last kind of tical Caves, siope, filled with ars, as well as oin the ground. oin alway in the iden of these be some of them. and Lovedale of the 3d and Frunkford and the limestone excavated bow, at one end aud at une end aud cavation is 150 wide, and only 2 e could also turn e. It is rather ong, 10 wide, and elongs to the 4th cliffs of Elkhorn ington, like a fine linestone walls. rarde and mure, yards and mure, ide and high. $\mathbf{A}$ fine atream issues from it, quite pe- by myself. I also macle a co. rennial and emprying into the Elk- map of it as far as I went, whici: 18 horn about 60 yarils from the cave. very difierent trom those populur Deer Lake belonga to the 5 th Se- catch-penny maps alrealy publishries. It is one of the largest natu. ed. In lact, all the popular accounts ral ponils of Kentucky, where being of this cave, inserted in the epherare, it is deeined a lake. Some- ineral press, are quite false, evagwhat circular, nearly two miles in gernted, or fahulons. Such in that circuit, cunstantly filled with water, copied in the Saturdiny Fivening Post without any outlet. It is between ngainst my consent, with my figure. Green River and Glasgow, at the The best account is that given by entrance of the Cumberlanil line- Farnham in the Arclieolngia A mestone region, where smaller sinks ricana; yet it is slso tame anil inand ponis are common; evidently perfect. It has inany branches, al one of thein, filled up by water. in the gallery form, with a flat roof,

Crauford's Little Cave, one mile but very uneven flowr, ascending anil from Mount Vernon in the sand- descending, with many fallen stones atone region, is 200 yards long, full forming sometimes hills. The of beautilul stalactitea. - branches are crooked, like a laby-

White Cave, near the Mammoth rinth, sometimes descending under Cave, is anotlier with handsome each other, with springs and a few white stalagmites of many shapes stalactical pillars. Panciful names on the floor. It was not there, as have been given to these branches, stated erroneously by Harlan, that galleries, crlled roums and halls the fulaxodon was found, but in the when expanding. The whole length Mummy Cave near it; a saltpetre is yet unknown, being very difficult cave, where 3 mummies were also to penetrate after 5 or 6 miles, but discovered. 9 to 10 iniles have been reached,

Bryan's Cave, near Lexington, is and are supposed to extend uniler a small dry cave, in limestone, with the bed of Green River, which I anall spring at the entrance. It doubt, as the whole cave appears to is like a crooked gsllery, 380 steps have been once the subterranean long, 6 to 10 feet high and wide, bed of a stream, which emptiel into with an even fluor and roof. It is Green River, not far from the enused by Mr. Bryan as a spring house. trance, where the chasm leads and It had hardly any diluvial inatter, reaches the river. Much anltpetre but has a vent or air hole.

Big Cave, in Rockcastle county, 1816; vats, oxen, anıl negrnes einnine iniles east of Mount Vernon, plnyed, as in a manufacture; 25 on Cronked Creek, is a fine saltpe.- iniles of extent in branches were tre cave, 700 yards long, surlace explored to seek for the nitrous about 121 acres, divided in many earth; no bunes and no mumnies rooms and branches. Breadth and were found there. The sides of the height froin 5 to 40 feet. There is galleries are conımonly smooth and a spring in it withnut outlet, but no of compact limestone, incrusted ataluctites. As much as $1000 \mathrm{lb}$. with efflorescencr, native nitre, of saltpetre was made there in one glauber salts, yelliw ochre, calcasingle lay. Mammoth Cave. The largest salt- places. They cover the few fossila petre cave in Kentucky, near the of the strata, yet I observed some aouth side of Green River, in the Marlrepores, a fine Mastrema, and sandstune hills; but quite in the a Turbinolite. In a room, a kind limestone beneath. Entrance in a of black flint or rather chert is found, cleft or chasm, very picturesque, of inclicating the cherty linieatone. which a figure is here given, drawn The temperature of this cave is 
permanent, at about 56 degrees; (Whlo as far south as lat. $89^{\circ}$. T therefore cold in summer and warm never a w a single one in Kentucky, in winter. It is the wintering but many gritty and limy angular quarter of thousands of bats of five boulders in some places.

new specien of mine which resort to it in winter only from 100 miles around $s$ and remiain suspended to the roof in a half -eleepy or torpic atate. Bach opecies appears to oc. cupy a gallery or room by itself. Large rats dwell there also in winter and feed on the bats the can catch or who fall; no snakes lwell there. In coming out of it in sumnier after an exploration, the outuide air appears as sultry as an oven, and in winter so cold as to chill and be dangerous for the health, by the sudden change.

This cave upon the whole appears very similar to one of Siberia described by Gmelin. The roof is fiat and lofty throughout.

21. Geological Btrata of Ohio and Kentucky. By C. S. R.

The following are the series of Geological formatione extending Irnm Lake Brie in lat. $42^{\circ}$ to Tennessee in lat. $361^{\circ}$ through Ohio Indiuna and Kentucky, chiefly extracted from ' my Geology and Oryctolong of Ohio and Kentucky. They are, as well as the Physical geography of these large states, almost unknown. The maps and accounte of : Maclure and James are quite erroneous.

Successive Beries, by stge.

1. Lowest series of formations-

Limestone.

1. Compact L. Grey chiefly.

2. Specular, blue.

3. Oolitic, white.

4. Shaly.

5. Cherty.

2d Series. Carbonic.

1. Clay slate.

2. Bituminous coal.

3. Fuliated alate.

3d Series. Grit (Gries of the Prench.)

1. Pebble stone.

2. Freestone.

3. Gritstone, highest stratum.

4. Sandatone, brown chiefly.

5. Iron stone.

4th Series. Clay.

1. Ferruginous clay.

2. Saliferous clay.

3. Murly clay.

4. Potters' clay.

5. Common clay.

sth Series. Alluvial.

1. Diluvium.

2. Alluvion.

But these formations do not always occur together; many are often lacking. When present the above is their respective position or most general succession of superin: cumbence. However there are many anomalies of position in vari.

The series begin at the deepeat ous places, which baffie all the or lowest formation and strata sctual fanciful oystems of Geology: nearly at the level of the sea, up to but find a very easy solution in $\mathrm{my}$ the highest in the Cumberland ontural theory.

mountain about 1700 feet abuve the For inatance, beda of coal are sea. But the tertiary formution or sometimes found between the strata latest do not rise so high. They are or beds of limestone! instead of all horizontal or nearly ao, belonging slate. Sleewhere between and to the Floetz formations of Werner. stone above the wlate. Large beds They all contain more or less fossil of limestone have often atrata of remains of the most ancient order, clay from 1 to 6 inches thick beincluding Alcyonites, Corals, and tween each stratum of limeatone, Trilobites, of 1000 new G. or N. either marly or saliferous clay. Sp. mostly difierent from those of Thus the coal and clay are ont of Europe and the Atlantic otateo. their natural position, breaking the

Primitive boulders are only series made out in Europe for the found, thinly scattered through whole world. 
lat. $89^{\circ}$. 1 one in Kentucky. and limy angular olaces.

iries, by Age.

of formations-

Grey chiefly.

\section{(1)}

e.

iic.

coal.

ress of the French.)

igheat stratum.

brown chiefly.

clay.

ay.

ivial

ormations do not gether; many are When present the spective position or ceasion of superinowever there aro of position in veriich baffle all the ystems of Genlogy; eany solution in my

beds of coal are between the strata estone! instead of ere between aandalate. Large beds: ave often atrata of 6 inches thick beratum of limestone, or saliferous clay. ind clay are out of sition, breaking the it in Europe for the
The Oolitlc serlea which had been / azain In N. Caroling towarls 1804. denied to Anierica, I have found in The first gold sent from thence to the Cumberland basin, but reduced the U. S. Mint was in 1814. The to a thin stratum, imbedded in quantity was sunall, but lias been in. otlier limeatone. 'This (Nolite is not creasing ever since, In 1830 the the false Volite of Burope, or Mint received and cuined 8134,000 granular andy limeutone; but the of gold, of which

true Oolite, formed by small white $\$ 128,000$ from $N$. Carolina. hullow globules, similar to the roe of $3,500 \quad$ S. Carulins. fishea.

My natural geological theory of But last year, 1831, the quantity thene western atrata, which was received and coined was $8: 98,000$ tuught in $\mathrm{my}$ lectures in the Uni- a prodigious increase of $86 ; 0,000$ veraity of Lexington as early as in one year.

1819 and 1820 , conoiats in deeming 8476,000 from Georgia. all these formations, beda and strate, $\$ 94,000 \quad$ N.and S.Carolina. withuut exception, formed by alter- 26,000 Virginia.

nate submarine eruptions of matter, 1,000 Alabama.

alime or water in the primitive 1,0100 Tennessee.

ocean, from oceanic SALSES or At this rate, the southern states volcanoes without fire. The dilu- will become a gold mining coustry. vium was formed by a flool of The gold is chiefly found in dilu. eruptive waters when the land vial and alluvial barren tracts had been uncoverell by the ocean. Dear the primitive' granitic range, This theory I am prepared to sup- called Blue mts. or Kitaniny, where port and maintain, prove and de- it blends with the Apalachian mts. fend against all the geologiats of the southern termination of the England, France, America, or the gritty Alleghany. It is procured whole world: whatever be the by washing chiefly. Some veine

looking at a few Buropean or local have lately been lound, and begia looking at a few Buropean or local to formations eleewhere. to be worked.

The Cheroki country, which is in the very centre of ouch region and mountains, is supposed to be very rich in gold, having perhape veins of $i t$ in aite. This han increas. ed the cupidity of theGeorgians, who have invaded those mines, and want to compel the Cherokis to evacuate the land; by nearly imitating the Spaniarda, and muking the Cherokis (who are as civilized as the

chiefis iron, hematite, pyrit thyst, beryls, apars, marlatone, bolites, nitre, sait, bitumen, oulphur, alum, vitriol, geoder, \&c.

\section{MINERAT.OGY.}

Gold alines of North America. By C. S. $\mathbf{R}$. Georgians) outlaws in their country. Gold mines bring "no solid

The gold mines of the United wealth, they are soon exhausted, or States, wore known to the Indiana the proceeds wasted. Genrgia will in 1539, when soto invaded them; find it out at her cost. Meantime but they had the ability to bewilder conipanies and adventurers are him, and conceal them. Elae this pursuing this delusive search; are country woold have been colonised succeed, but an many fail or hardly or desolated by the Spaniarda. procure gold enough to repay their The Brench of Laudoniere and the expenses. But aterile worthleas first settlers of Virginia aleo vainly lands are becoming valuable, and cought them. Their knowledge often sell at random and high rates was almoet loat, when discovered to speculators. 


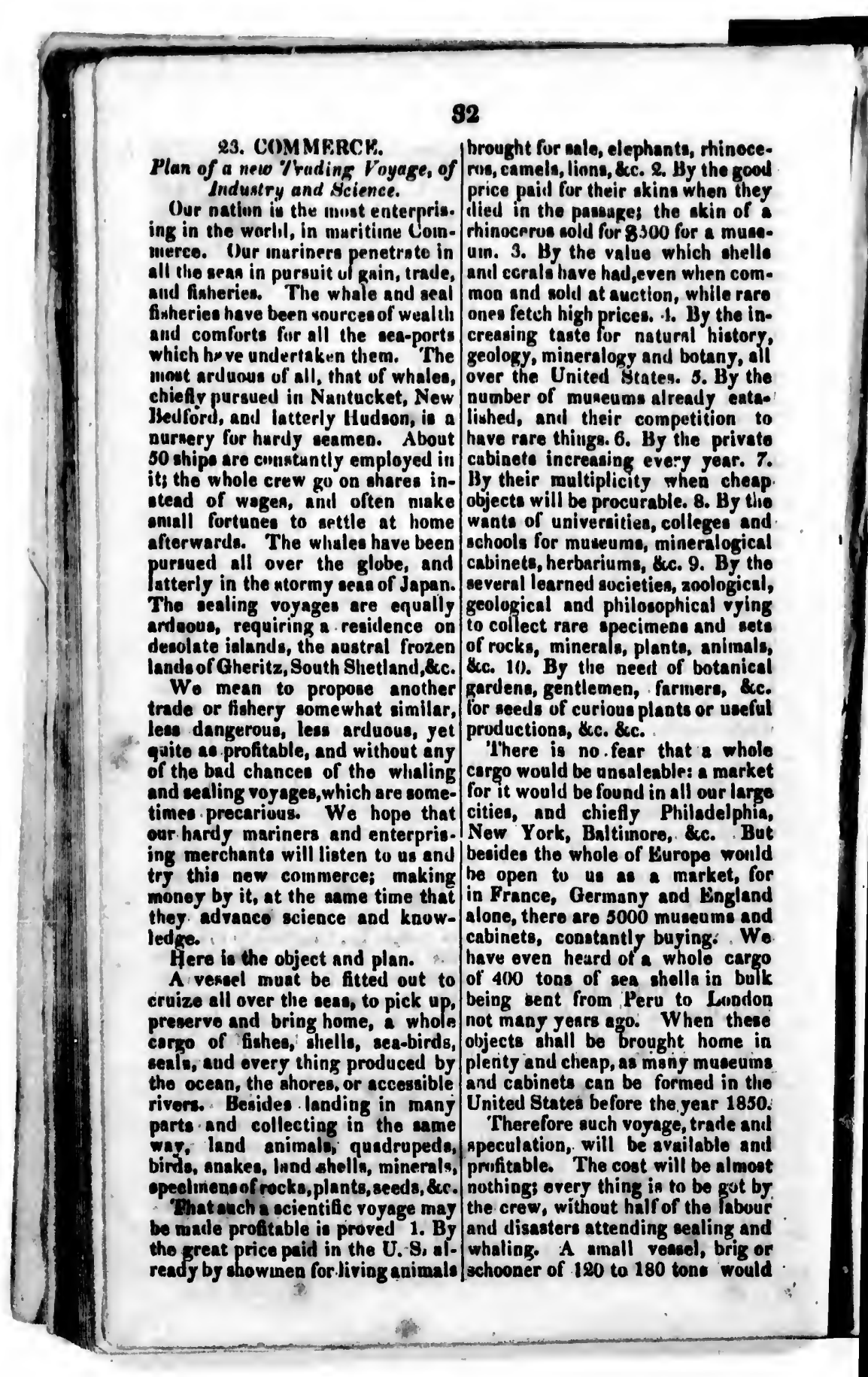


hants, minoce2. By the gooll kins when they the skin of a 300 for a muse- which shells even when com. tion, while rare 2. 1. By the innaturnl history, and botany, ali tates. B. By the is already eats-" competition to By the private (B) 7. every year. urable. 8. By the ies, colleges and nineralogical ns, min. 9 . Bi the ietien, znological, ilosophical vying ecimens and sets s, plants, animala, needl of botanical en, farmers, \&c. , plants or useful \&ac. fear that a wholo ear thate: a market und in all our large und Philadelphia, timore, \&cc. But of Burope would market, for any and England 3000 museume and ntly buyings. We of a whole cargo of alls in buik Peru to Luadon When these brought home in as many museuims 5 be formed in thie fore the Jear 1850. hoyage, trade anil I be available and cost will be almoot hing is to be gat by thalf of the labour tending sealing and nall veasel, brig or to 180 tons would do for the first experiment, 12 to could not fail to bring a valuable 16 men could mevigate it, half the cargo of all these natural notione, numbrr required for whaling. The froin a huge Sea Blephant, head, outfits would be only staves and akin, and all, down to 10,000 fiahes planks to be made up into casks picked up at seas and 5000 kinds of and buxes on board, some casks of shells, $2(10$ of each kind would be liquor to preserve fishes, \&c., large one million, which at one cent aploce fanes may be eaten and the skin only amount to 810,000 , and some only preserved in brine. Shells sholls will be worth a dollar instead and atones cont no trouble to pick of a cent.

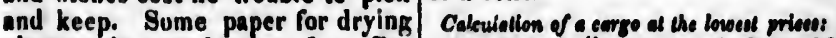
plants, salt, nets, bottles, \&ec. Be- $1,0110,000$ shells at 1 cent 810,000 pudes one or two years provisions to,000 hahes at 25 cents 2,500 for the anall crew. No portcharges Minerals, rocks, fossils, \&ec. 2,000 to pay, the vessel need not go into Living animals - 2,000 any purt to trade. The outhits may Other animals preservel 2,500 be Insured just like those of whale. Preaerved plants and seeds 1,500 men at 5 or 6 per cent. per onnum only.:

Wo should not advise the rensel to be fitted for sealing and whaling at the same time; because it is more expensive, and the crew might neglect the object of the voyage in pursuit of whales. We should rs. ther advise, if a greater capital is in 20 shares would give 8375 for disponible, to fill up the ship with each, and the other 87300 for the articles that may sell with some outfitters, being 373 per cent. profit profit at ports in the way, such as on 82000 for two years! But perco flour and provisiuns, \&cc.; or else to haps by better sales, 8500 to 700 take out a freight to the West In- may be divided on each share.

dies or Brazil at the outset, and set AII this is so plausible, that - we off from thence on the voyage. invite the experiment to be made

We deein that a captain of com- at once, and any ship owner or mon capacity, but some education, whaler who will undertake it may would do to conduct auch a voyage; receive encouragement in Philadef. if he has aome acquaintance with phia, by writing to us post paid, if science, or will tollow the written no one will try, we mean to try it instructions clnaely atill better; ourselves, by chartering a amall brig, otherwise there must be a supercar- and raising the 82000 outfita by 80 on board, acquainted with natu- divilling them in 20 shares of 8100 , ral sciences, to direct the proceed- of which 3 nre already subscribed. ings.

As to the places to go, no one can first to open a prow of beling the go amiss. An where will do; but try and linowledge to our counery. the most healthy, fraitful, and un. We have had this plan in contem. explored countriea best of all. For plation for several years past; but instance: Brazil and Patagonia, Chi- have waited to publish it, until we li, Peru, Guatimala, Weat Mexico, have seen the time arrived when it California, East conat of Africa, Bor- can be made very profitable. For neo, Philippines. New Guinea, Aus. inerly, when younger, wC. thould tralia or New Holland, the South have been delighted to go on such a Bea Islands, eac. "Any one expluring the coasts of yet budding as it is now.: We muat thowe countriea for one or two years depend on some active young mao 


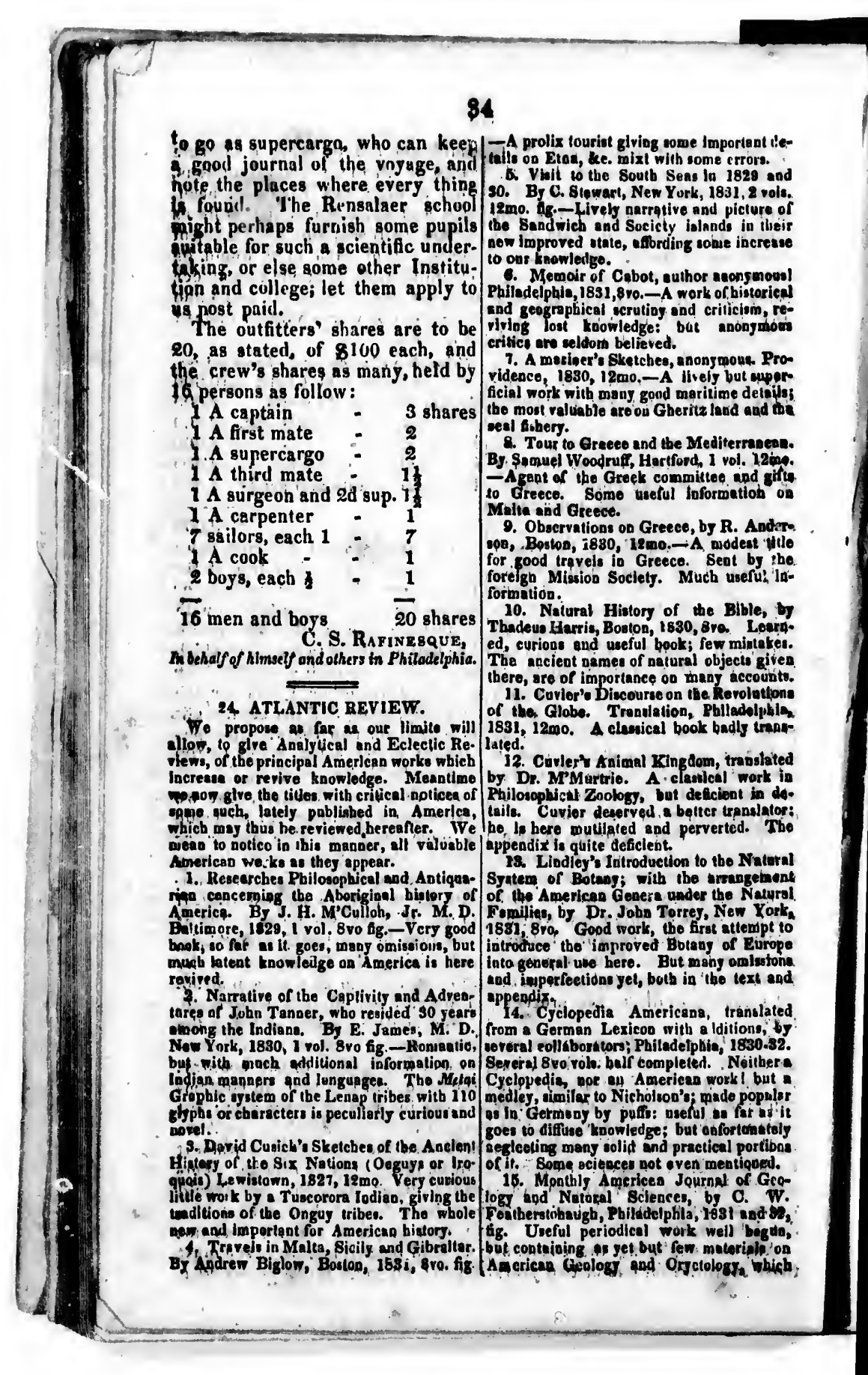


ing some Imporiant thexI with some errors. ath Sest In 1829 and New Yurk, 1831, 2 rols. arrative and picture of ocicty islands in their afording sohse ineresse

bot, euthor anonymous! 0.-A work of bistorical ruting and criliclem, re: dge: bat soonymoen

etches, anongmouns. Prom 0. -A lively but auper good maritime detaila oi Gheritz lend and the and the Meditermaess. Hart Hord, 1 vol. 12 ing. eek committee and gifts bueful informetion on ob Greece, by R. Andarm 12 mo $-A$ modest Hile ociely. Much usefus inistory of the Blble, by saton, 1830, 8vo. Learyeful book; few mistakes. of netural objects giver riance on many accounto. course on the Revolutione Tranalation, Philadoliphis. alanicol book badly trant imal King dom, translated ie. A clastleal work is logs, but deficient in de erved a beiter uried. The ted and

introduction to the Natoral ntroduction to the Natwengent Genere under the Netural. John Torrey, New Yortk, work, the first attempit to proved Bolany of Europe prove. But mans omlations. yet, buth in the text and

Americana, Iranblated. Cexicon with a iditions, iy  half completed. Noither an American woskl bat Nicholuon's: piede populor pufs: nsefui an far wis lt puis: asefut as fortonately owledge; but enfortond portibut colia

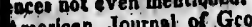
sclences, by $c$. W. Phildelphi, 1831 and 52 jodicul pork well thegan colle meteriele - jeribut require setive exerilowe and travele to eolloct. 16. Voyages of the Companions of Columbun, by W. Irvio; Pbiladelphia, 183I 3vo. A aeedful revival of American know Vedge, maus pupular by the ityle and fane of the writer, han bis ifre of Columbun.

17. History of New Plymouth, by $F$. Baylies, Bsoion, 1830, 2 vols. 8vo. A proli but valusble fragment of North American History. Much bistorical knowledge is here when New Plymouth was united to Masachuseto.

18. History of Lonluiens by Barbe Maro bols, Iranslation, Philadelphia, 1830, 8vo. Well written, but deficient in the early blatory; better in later times.

19. History of Penneylvonia to $\mathbf{1 7 7 6}$ by Gordon, Phlindelphla, 1828, 8vo. Well writlen, few omistions, a creditsble work. 20. Hislory of New York, by Moulton. New York, lst and 2d parts, 8vo. 1824 and 1826. Excelleot work, copious on earis bistury, ooly carsied as yet to 1633 .

21. Treaties of the United States with the Indlan trlbes; Washington, 1828, publisbed by order of Congress. Furnishing Important official docnments for History. 22. Annals of Ameriea, by Holmes, 2 editlon, Cambridge, 1829, 2 vols. 8vo. False tille: it is Chronologleal History of the Eoglish Colonies of Nomb America only, and the United States; oompendious, yet lame. 23. Trnvols is Guatimale or the United Provinees of. Central Americ in $\mathbf{1 8 2 7 - 8}$, by Duun, New York, 1828, 8vo. Interestine account of a couning elmoit unknown; by an agent of the Bible Society; rather eupenficial, but many additions to lpowledge. 24. Sketches of a Tour to the Lekes in 1829-7, by Tb. L. M'Klaney, Baltimore 1827, 8vo. fig. Tedlone Bpistles of a touris or niber Indian agent; but sume addition, knowleilge may be gleaned therein.

25. Narrstive of a second Expedition 10 the ahores of the Americen Polar Sea, by Capt. J. Fonklin and. Dr. J. Richardson Philadelphia, 1828,8vo. Important addition to geography, geology aod.all the cognate sciences.

26. Orwitholngitnl Bitgraphy of the Bird of America, by J. J. Aucubon, Philerietphia, 1831, 4to, first volume, containiog tbe. Biograpby of 100 Birds. Excellent work of an author uniting the charactera of a nafuraliat, painter, a traveller, and a close observer. is the tezt of bis gigancle work on our birds or their colored figures of natural hize; oplentid monument of geplus and fine arte. 27. Medical Flory; or Mannal of Medical Botany, of the United Stmles of Nort America, by C. 8 . Kabnerque, Pbiladetphis 1828.80, 2 volı. 18mo. 500 Ag. A ret useful compilation, embody in soll the seatur knowledge on our Medical Bolany, with. mullilude of original addislona, both medical and botanical.
28. The Pulpiol, of the ant to enm end reo

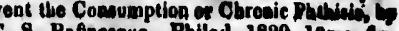
.

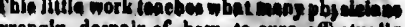

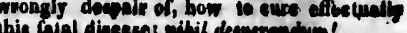

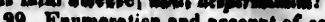

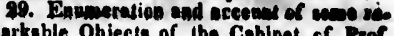
Refinble Objecte of the Cabjuet of Prof. Rafinerqua, Philad 1891, Bvo. (recs. In 16 cols I Zuology, ebieny fonili of Keatucks, mere the licice solumes often can do.

80. Mongereph of the Bivalve Shelle of the river Obia, by C. S. Rafinesque, tranalatPalladelphis, 1832, 12 by 1 . A. Poulson, Philadelphia, 1832, 12 mo. 1 fig. $68 \mathrm{op}$. The frat priginal work on our fuvlatile chancbolozy. The tranulater has omitied the 70 figures of the origiant, and the con(ipuation carried to 1.18 epecies publlabed in 1831. He mlght also have edded the posterior synonymo to sid the gindents.

81. Manual of Boteny for North Ameriea, Prof. A. Eatan, ofthedition, Albany,1820, 12mo. A populer compilation; few reach bere so meny edlitions; this lant ls mueh enlarged and improved, Incluting the coulhern plants of Purih, Nuttal and Elliout, bat no one elat: thetefore deficignf en a compilation getherul use.

82. Geologleal Text Book on North Araerican. Geotogy, by Prof. A. Ealon, Albany, $1830,8 v 0$, igg ad a Geological map of the state of New Xork. Talerable stlempt eo far as New York le concerned, but totalis debcicat is oryctology or foesil remainu, and miso inkiag the geologieal region fromi - Bonton to Lake Drie for the whole of $\mathrm{N}$. America, as the Engliab Geologitum wistake the Geolong of England for that of the morld.

33. Weboter'a. Dictionany of the Engllat Language, Bopton, 1880, 2 , rols. 410, and bridged in o thith 8ro. Bully, elaborate work, adding: many thoumnd wurds to our Lexicon; but lacking get as many more. The Bismological partis copious, set totally deficiest to the 8anserit, arst parent of the sngliobs of well as Latin and Greek, and - were all their wortas withont bardly any exeeption, can be traced.

\section{MISCELILANY.}

Periodical Preas. - Nearly, 1000 periodieal nited Sntes; nome sere of rery limiud Circuletion anppented by Adrertisementu and the monopols of 10 m miter of postage. In Prance, they have doubled nince the Berclution of Juh 18d0. They nere 210 before or which 150 out 'of Partus nom they are ace, 400, of which $\$ 10$. eut of $P$ aris.

a 1831. Mr. Giben oo the 22d ont and P A Brome cece'y is the presjin viem complece seolosical bures of Fin ntate.

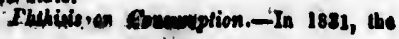




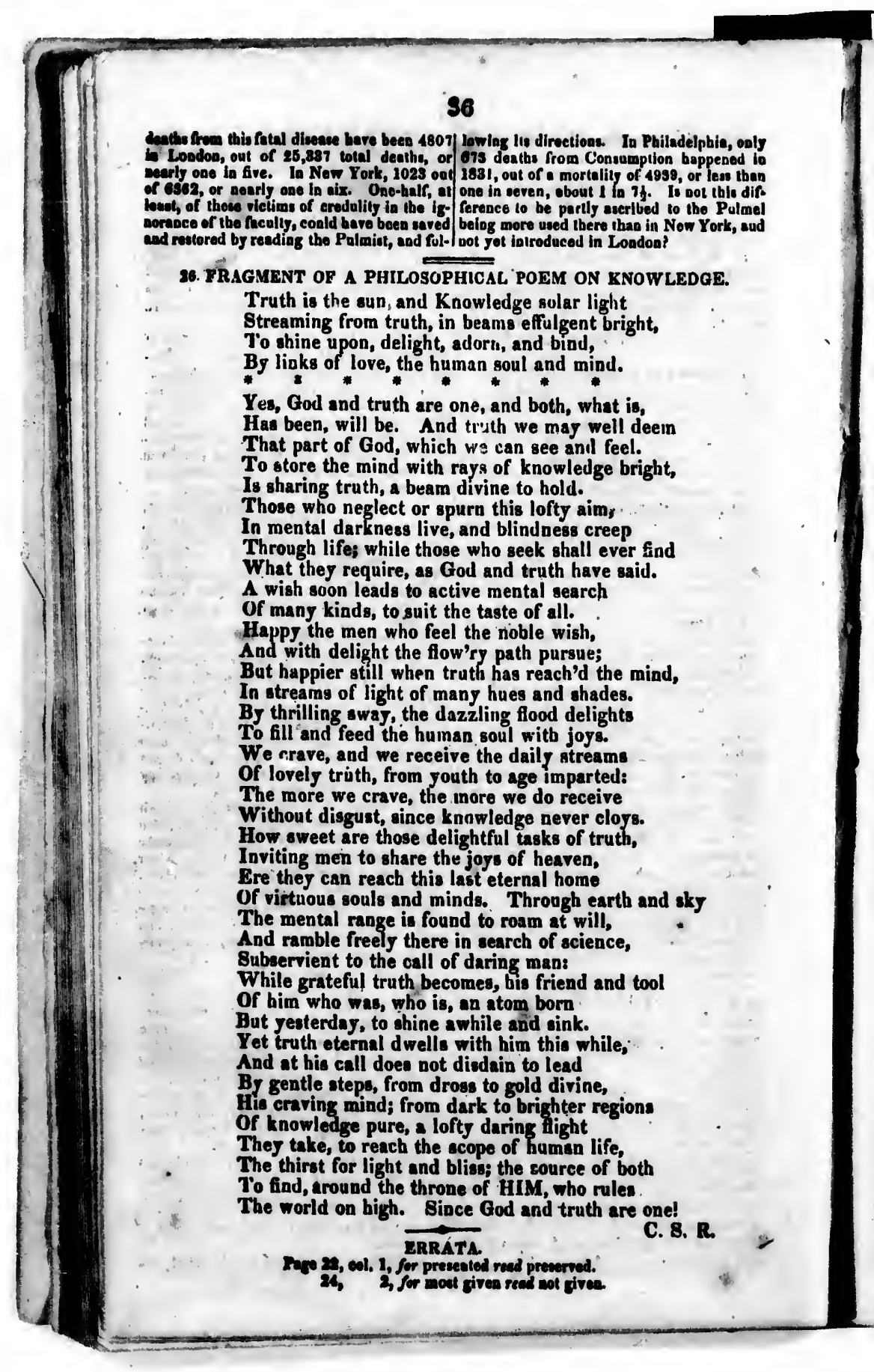




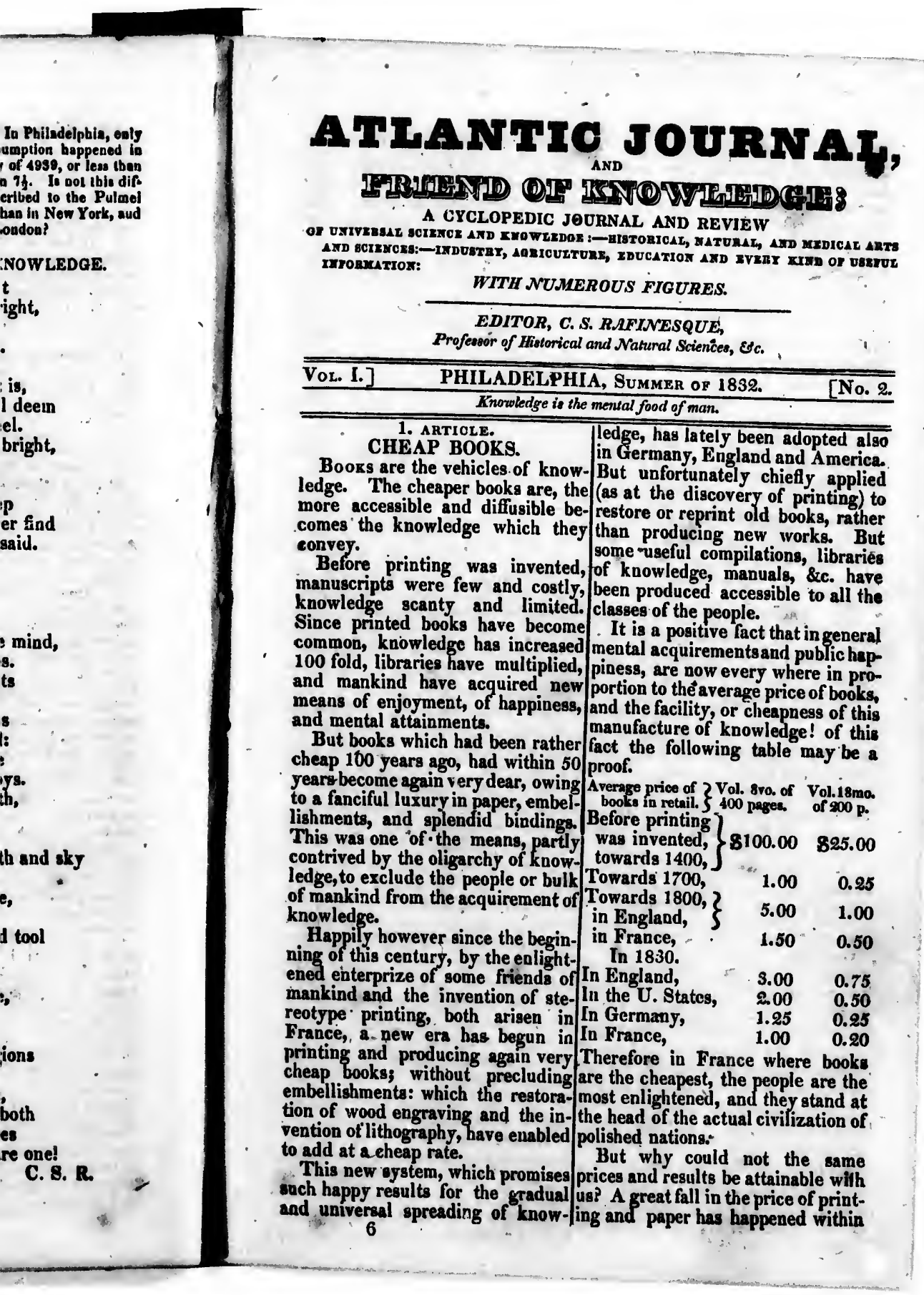


15 years, all the prices have fallen! IVhen I began my investigation of from 25 to 50 per cent, even for Ste-lhese American Glyphs, and became reotyping.-Engraving alone in all convinced that they must have been its branches is yet too costly, wood groups of letters, I sought for the engraving more so than even in Eng- Elenentary Letters in all the anland, for lack of engravers. We ail- cient known alphabets, the Chinese vise 100 of the woud engravers of Sanscrit and Egyptian above all; but England, who work at two shillings in vain. The Chinese characters ofa day to come here. Notwithstani- fered but few similarities with these ing, some useful and clieap works glypls, and not having a literal but ornamented with wood engravings syllahic alphabet, could not promise have been published, such are Pro-the needful clue. The Sanscrit alfessor Nuttall's Birds, and Profes- phabet and all its derived branches, sor Rafinesque's Medical Flura. including even the Hebrew, Pheni-

The high duties and taxes on pa- cian, Pelagic, Celtic and Cantabrian ner are also another evil; notwith-alphabets were totally unlike in standing the fall in prices, paper forms and combinations of grouping. could be imported for our periodical But in the great variety of Egyppress and books from Germany, tians form of the same letters, I France and Italy at one half the ac- thought that I could trace some tual cost, if our duties were not pro- resemblance with our American hibitory and a shameful tax on know-jGlyphs. In fact I could see in ledge.

them the Egyptian Cross, Snake, Our publishers who have capital, Circle, Delta, Square, Trident, Eye, employ it chiefly in reprinting Eu-Feather, Fish, Hand,\&c. but sought glish books, to avoid paying copy- in vain for the Birds, Lions, Sphynx, rights. They steal English know- Bcetle, and 100 other nameless signs ledge, and cramp with it American of Egypt.

genius. When these impediments However, this first examination will be removed we can print here and approximation of analogy in as cheap as in France, and send the Egypt and Africa was a great preproductions of our press all over the liminary step in the enquiry. I had world, as the French now du theirs: always believed that the Atlantes of besides improving ourselves.

Benj. Frasklis, junr. $-\infty$

Africa have partly colonized Ameri-

,

$$
\text { 2. PHILOLOGY. }
$$

second Latter to Mr. Cinampolitiox on the Graphic Systems of America, and the Glypha of Utocem or Pacesque, i Glypha of Otocem or Pacessue, in Central

I have the pleasure to present you hereto annexed, a tabular and com paritive view of the Atlantic alplia bets of the 2 Continents, with a spe cimen of the Groups of Letters or Glyphs of the monuments of Otolum or Palenque: which belong to my 7 th series of graphic signs, and are in fact words formed by grouped letter or Fleinents as in Cliinese Charac ters; or somewhat like the cypher now yet in use among us, formel by acrostical anagrams or combination of the first letters of words or names.

ca, as so many ancient writers have for any preserved fragments of the pliabets of Western Africa, and Lybia, the land of the African Atlantes yet existing under the names of Berbers, Tuarics, Shelluhs \&c.

This was no easy task, the Atlantic ntiquities are still more obscure than the Egyptian. No Champollion had raised their veil; the city of $\mathrm{Fa}$ rawan, the 'Thebes of the Atlantes, whose splendid ruins exist as yet in the Mountains of Atlas, has not even been described properly as yet, 101 its inscriptions delineated.

However $\mathbf{I}$ found at last in Gramay (Africa Illustrata) an old Lybian alphabet, which has been copied by Purchas in his collection of : old alphabets. I was delighted to find it so explicit, so well connected 
41

investigation of ihs, and became must have been sought for the in all the an ts, the Clinese in above all; but characters ofrities with these ing a literal but ula not promise The Sanscrit al rived branches, Hebrew, Pheni and Cantabrian ally unlike in ons of grouping. triety of $\mathbf{E g y p}$ same letters, I id trace some our American I could see in Cross, Snake, e, Trident, Eye, \&c. but sought Lions, Sphynx $r$ nameless sigms rst examination of analogy in was a great pre enquiry. I had $t$ the Atlantes of olonized Aınerient writers have led me to search fragments of the Africa, and the African Atander the names :s, Shelluhs \&c. 1sk, the Atlantic more obscure No Champollion ; the city of $\mathrm{Fa}$ of the Atlantes, ins exiat as yet f Atlas, has not I properly as yet, delineated.

d at last in Grata) an old Lybian B been cppied by illection of - ola s delighted to well connected with the Egyptian, being also an/have a slight affinity with the EgypAcrostic Alphabet, and above all to tian, they are

find that all its gigng were to be seen in the Glyphs of Otolum. Soon of- Nose ter appeared in a supplement to Claperton and Denham's travels in Africa, another old and obsolete $\mathrm{Ly}$ bian alphabet, not acrostical, found by Denham in old inscriptions among west of Fezan: which although unlike as many as 12 out of 16 being conthe first had yet many analogies, similar. and also with the American glyphs. Thinking then that I had found the primitive eleuents of these glyplis, I hastened to communicate this important fact to Mr: Duponceau (in a printed letter directed to him in 1828) who was struck with the analogy, and was ready to confess that the glyphs of Palenque might be alplabetical words; al though he did not believe before that any Ainerican al phabets were extant But he could not pursue my connec tion of ideaş, analogies of signs, lan guages and traditions, to the extent which I desired and now am able to prove.

Ifr. L. Nif $E$ Mah Mauh.

Sigah Sev.

aturn Siagh Sev.

Venus Uaf Ath.

Tar

Aip
Eye

Nose

Ifr Rinif

Fand Vuld Hul, Chil.

Earth Lambd Landa.

Mah Maral.

ire Rash Purali.

Moon Cek Selka, Kres.

Mars Dor Hares, Thor.

Mercury Goreg Mergor.

Venus Uaf Uenas.

Siash Satur, Shiva.

upiter Theue Theos.

Therefore the numerical analogy is only 32 per cent with the Egypian, while it is 75 per cent. with the Pelagic. Another proof among

To render my conclusions per- many that the ancient Atlantes were

spicuous, I must divide the subject intimately connected with the Pelainto several parts: directing niy en. gian nations of Greece, Italy, and quiries 1st. on the old Lybien alpha- Spain; but much less 80 with the bet $3 \mathrm{dly}$. Cn their elements in the Ame- borrowed perhaps their graphic sysrican glyphs. 4thly. On the possibi- tem.

lity to read them. While the exa- This system is very remarkable. mination of their languare in con-1. By its acrostic form. 2. By havnection with the other 1 t pntic lan- ing only 16 letters like most of the nection will be the theme of $\mathrm{my}$ prinitive alphabets, but unlike the guages, will be the theme of $\mathrm{my}$ prinitive alphabets, but unlike the

I. The old Lybian delineated in susceptible of 22 sounds by modifithe Table No. 1, has all the appear- cation of 6 of the -letters, as usual ance of a very ancient alphabet, among the Pelagian and Etruscan. based upon the acrostical plan of 6 . Above all by being based upon Egypt; but in a very different lan. the acrostica of 3 important aeries guage, of which we have 16 words of physical objects, the 5 senses represerved. This language may havepreseuted by their agents in $\operatorname{man}_{\text {, }}$ preserved. This language may have preseated by their agents in man, perhaps the Getulians (GE-TULA, planets: which are very philosophior Tulas of the plains) or of the cal ideas, and must have originated Ammonians, Old Lybians, and also in a civilized nation and learned Ammonians, Old Lybians, and also in a civiantes. Atiantes.
Out of these 16 words, only 5 being also rude delineations of these 
physical objects or their emblems. I might have given and compared The ear, eye, nose, tongue and hand several other Lybian al phabets found for the 5 senses. The triangle for in inscriptions; but as they have been the earth, fish for the sea or water, delineated without a key nor names, snake for the air, flame for fire. A it is at present very difficult to decircle for the sun, crescent for the cypher them. I however recommend moon, a sword for Mars, a purse them to the attention of the learned, for Mercury, the $\mathbf{V}$ for Venus, dou- and among others, point out the Lyblc ring for Saturn, and trident for bian inscription of Apollonia, the Jupiter. Venus being the 5 th planet harbour of Cyrene, given by Lacella has nearly the same sign as $U$ the in his travels in the Cyrenaica. The 5 th letter.

letters of this inscription appear more

These physical emblems are so numerous than 16 or even 22 , and natural and obvious, that they are although they have some analogies sometimes found among many of the with the 2 Lybian alphabets, yet ancient alphabets; the sun and moon approximate still more to the Demoeven among the Chinese. But in tic of Egypt and the Phenician. the Figptian alphabets, the emblems But the insoriptions in Mount Atlas apply very often to different letters, and at Farawan, when collected and owing to the difference of language decyphered, will be found of much and acrostic feature. Thus the hand greater historical importance.

applies to $D$ in Eogptian instead of III. Meantime in the column No U, the eye to $R$, the circle to 0 , the 3 of the tabular view are given 46 snake to $\mathbf{L}, \& \mathrm{sc}$.

3 of the tabular view are given 46
Elements of the Glyphs of Otolum

II. The second Lybian al phabet or Palenque, a few of these glyph No. 2 in the Tables, was the an- being given also in column Ko. 4. cient alphabet of Tuarics, a modern These 46 elements are altogether branch of the Atlantes, until super- similar or derived from the Lybian seded by the Arabic. Denham found prototypes of No. 1 and 2. In some with some difficulty its import, and cases they are absolutely identic, and names of letters which are not the conviction of their common oriacrostic but literal, and 18 in num-gin is almost complete, particularly ber. It is doubtful whether these when taken in connection with the names were well applied in all in- collateral proofs of traditions and stances, as the explainer was igno-languages. These elements are rant and Denham not aware of the somewhat involved in the grouping, importance of this alphabet. Some yet they may easily be perceived and appear not well named and $U$ with separated. Sometimes they are ar$\checkmark$ have the same sign $W$; but these namented by double lines or otherare always interchangeable in old wise, as monumental letters often are. langusge, and in al phabet No. 1 Sometimesunited to outside numbers $\mathbf{V}$ is called UAF instead of VAF, represented by long ellipses meaning and $U$ is VULD instead of UULD? 10 and round dots meaning unities, As we have it, this alphabet is which approrimates to the Mexican sufficiently and obviously derived system of graphic numeration. Befrom the First, 11 out of the 16 let- sides these 46 elements, some others ters being similar or nearly 80, while may be seen in the glyphs, which I only 5 are different, $\mathbf{E}, \mathbf{M}, \mathbf{R}, \mathbf{G}$ and left off, because too intricate; alZ. This last appears the substitute though they appear reducible if a of $T H$, of No.1, and $G H$ represents larger table could have been given. G. Yet they are by far more alike There is hardly a single one that than the Demotic is from the Hi- may not be traced to these forms, or eratic Egyptian, and I therefore thatbaffles the actual theory. Theredeem this No. 2 a Demotic form of fore the conclusion must occur, that the ancient Lybian or Atlantic. such astonishing coincidence cannot 
and compared phabets found hey have been ey nor names, ificult to deer recommend f the learned, at out the Lypollonia, the en by Lacella renaica. The n appear more even 22, and me enalogies Iphabets, yet to the Demoe Phenician. Mount Atlas collected and und of much rtance.

e column No. are given 46 is of Otolnm these olyphe olumn re altogether n the Lybian 12. In some yidentic, and common ori, particularly tion with the aditions and dements are the grouping serceived and 8 they are orines or otherters often are. tside numbers ipses meaning aning unities, the Mexican eration. Be, some other: pphs, which I intricate; al educible if a been giren. igle one that rese forms, or leory. Thereist occur, that idence cannot he casual, but it is the result of ori-/will belong to $\mathrm{mr}$ third letter. ginal derivation. will now merely give a few attempts The following retharks are of some to read some of the groups. For inimportance.

1. The glyphs of Otolum are writ- 1 . The group or word on the seat ten from top to bottom, like the of the sitting man of plate 4 of monuChinese, or from side to side indif- ments of Palenque, I read UOBAU ferently like the Egyptian and the being formed by a hand, a tongue, Demotic J ybian of No. 2. We are a circle, an ear and a crescent. It is not told how No. 1 was written, but perhaps his name. And underneath probably in the same way. Several the seat is an eye with a small circle signe were used for the sarne letter inside meaning $\mathbf{E B}$.

as in Egypt.

2. In plate 5 , is an eye with 2 an-

2. Although the most common nexed rings, meaning probably iBAB way of writing the groups is in rows and perhaps the Sun, which is BAP and each group separated, yet we in the Lybian alphabet.

find some framed as it were in oblong 3. In plate 7 , the glyph of the squares or tablets like those of Egypt. corner with a head, a fish and a creSee plate 12 of the work on Palen- scent means probably KIM.

que by Delrio and Cabrera. In that 4. The 1st glyph of plate 15, is 12th plate there are also some singu-probably BALKE.

lar groups resembling our musical 5. I can make out many others, notes; could they be emblema of rearling ICBE, BOCOGO, POPO, or 'igs or hymns?

3. The letter represented by a. If these words and others (although bead occurs frequently; but it is re-some may be names) can be found markable that the features are very in African languages, or in those of different from those of the remarka- Central America, we shall obtain different from those of the remarka- Central America, we shall obtain ble race of men or heroes delineated perhaps the key to the whole language of Old Otolum. And next 4. In reducing theee olements to reach step by step to the destrable the alphabetical form, I have been knowledge of reading these glyphs, guided by the mere plausible theory which may cover much historical evolved by similar forms. We have kñowledge of high import. Meannot here the more certain demon- time I have open the path, if my stration of Bilingual inscriptions; theory and conjectures are correct, but if languages should uphold this as I have strong reasons to believe. theory, the certainty will be increas- Besides this monumental al phaed of the Atlantic origins of Otolum bet, the same nation that built Oto-

IV. - But shall we be able to read lum, had a Demotic alphabet bethese glyphs and inscriptions? with-l longing to my 8th series; which waa out positively knowing in what lan- found in Guatimala and Yucatan at guage they were written! The at- the Spanish conquest. A specimen tempt will be arduous, but is not of it has been given by Humboldt in impossible. In Egypt, the Coptic his American Researches, plate 45, has been found such a close dialect from the Dresden Library, and has, of the Egyptiau, that it has enabled been ascertained to be Guatimalan you to read the oldest hieroglyphs. instead of Mexican, being totally We find among the ancient dialects unlike the Mexican pictorial manu. of Chiapa, Yucatan and Guatimala, scripts. This page of Demotic has the branches of the ancient speech letters and numbers, these repreof Otolum. . Nay, Otolum was per- sented by strokes meaning 5 and haps the ancient TOL or TOLA, dots meaning unities, as the dots seat of the Toltecas (people of ' $\mathrm{Tol}$ ) never exceed 4. This is nearly simiand their empire; but this subject lar to the monumental numbers. 
The words are much less hand-|primitive sources, nor through all it some than the monumental glyphs; variations and anomalies.

they are also uncouth glyphs in rows But no very speerly addition to formed by irregular or flexuous hea- this knowleilge is likely to be provy strokes, inclosing within in small duced, since Mr. Webster has stated strokes, nearly the same letters as in a letter inserted in the Genesee in the monuments. It might not be Farmer of March 1832, (written to impossible to decypher some of these vindicate some of his improvements manuscripts written on metl paper: (in ()rthography) that no one has been since they are written in languages found in America nor Fingland able yet spoken, and the writing was un. to review his introduction? although derstood in Central America, as late many have been applied to! But I as 200 years ago. If this is done it was not onc of those; few knowing will be the best clue to the monu- of my immense researches in lanrnental inscriptions.

guages, I was not consulted, clse I C. S. RAfinesque. could have done ample juatice to the Philualelphia, February, 1832 .

Note. - While this letter is going It is not now a review of his lato press, we hear of the death of the bours that I undertake, but merely learned Champollion, a great loss to an enquiry into the prinitive origin aciences and crudition. The 3 let- of our language, extracted from my ters directed to him were written in manuscript philosopliy of the EnJanuary, February and March of glisli, French and Italien languages this year, while his career of useful-lcompared with all the other languaness was yet unimpaired; but they ges or dialects of the whole world, were as much intended for the learn- not less than 3000 in number! ed all over the world, as for himself, The modern English has really and therefore were printed instearl ouly one immediate parent. The Old of being sent. The third which is English, such as it was spoken and to appear in the next number, will written in England-between the however be inscribed to Klaproth as years 1000 and 1500 , lasting about a substitute.

500 years, which is the usual dura-

We have Intely heard that the 1st tion of fluctuating languages. Our number of 3 excursions to Mitla and actual English is a natural deviation Palenque. performed in 1805 to or dialect of it, begun between 1475 1807, by C'apt. Depaix, has lately and 1525, and gradually improved been ur.blish:- in Paris under the and polished under two different title of Mexican Antiquities; but it forms, the written Fnglish and the has rut reached us.

$$
\text { -ar }
$$

spoken English, which are as different from each other as the English from the French. These two forms

3. Primitive Origin of the EN ghish Langlige.

have received great accession, by The best work on the philosophy the increase of knowledge and borand affinities of the English lan-words unknown to the Old Einglish. guage is at present, the Introduction 'l'hey are both subject yet to fluctuby Noah Webster, to his great Dic- ations of orthography and pronuntionary. Yet although he has takenciation, which gradually modify enlarged views of the subject, and them again.

by far surpassed every predecessor, The Old English existed probably he has left much to do to those fu- also under these two forms, and had ture philologists and philosophers several contemporaneous -dialects, who may be inclined to pursue the as the modern English, of which the subject still further: not having Yorkshire and Scotch dialects are traced the English language to its most striking in Burope, while the 


\section{5}

through all its es. y addition to ely to be proater has stated the Genesee 2, (written to improvements o one has been England able tion? although ed to! But I few knowing Irches in lannsulted, else I e justice to the ster.

iew of his lae, but merely rimitive origin acted from $\mathrm{my}$ iy of the Enien languages other languawhole world, number!

ish has really arent. 'The Old vas apoken and - between the lasting about he usual durainguages. Our itural deviation $n$ between 1475 ually improved - two different inglish and the ch are as differas the English These two forms accession, by wledge and borkin languages, he Old English ct yet to fluctuiy and pronun. idually modify

existed probably f forms, and had ineous dialects, ish, of which the itch dialects are arope, while the
Guyana Creole and West India the time of Romulus was quite a Creole, are the most remarkable in different language from that spoken Anerica. Another dialect filled in the time of Augustus, altho' this with Bengali and Hindostani words was the clild of the former, this of with Bengali and Hindostani words was the chian, \&c.

A complete conparison of the old The following table will illustrate and modern English has not yet been this fact, and the subsequent re. given. A few striking examples will marks prove it.

here be inserted as a specimen of I. Old English sprung partly from disparity.

Written written Written Spoken Brittain sprung from the Celtic of Londe Iand Land. West Europe,

Sterre Star Star. 3d Step. This Celtic from the Erthe Earth Erth. Cumric or Kimran of Europe.

Erthe Lth Step. The Cumric from the Yle Island Ailend. Gomerian of Western Asia.

Bencthen Beneath Binith. 5th Step. The Gomerian from the Hewyu Heaven Hev'n. Yavaun of Central Asia.

6th Step. The Yavana was a dia(155), we find lect of the Sanscrit.

II. Source. 'The Old English the English language very diferent partly sprung from the Anglo-Saxon from the actual, at least in orthogra-part pritsin.

phy, for instanceEng. of Written Spoken from Saxon or Sacasenas of Germa1555. Mod. E. Mod. E. ny.

Preste Priest Prist. 3d Step. The Saxon from the Euyll Evil Ivl. $\quad$ Teutonic or Gothic of Europe.

Youe You Ya. 4 4th Step. The Teutonic from the Fyer Fire Fayer. Getic of East Europe.

Howse House Haus. $\begin{array}{r}\text { 5th Step. The Getic from the Ti- } \\ \text { 5 }\end{array}$

This old Euglish is supposed to ras or'Tharaca of West Asia. (Thrahave sprung froin the amalyamation cians of the Greeks.)

of 3 languages, 1. British-Celtic. 6th Step. The Tiras from the 2.Anglo-Saxun and Norman-French, Cutic or Saca of Central Asia, between the years 1000 and 1200 . called Scythian by the Grecks.

This This has been well proved by many 7 th Step. The

But the successive parents and III. Source. Old English partly the genealogies of the Celtic, Saxon sprung from the Norman French.

and Norman are not so well under- 2d Step. The Nurman French was and Yeod. Yet through their successive sprung from the Romanic of France. and gradual dialects springing from $3 \mathrm{~d}$ Step. The Romanic from the each other, are to be traced the ano- Celtic, Teutonic and Roman Latin. malies and affinities of all the mo- 4th Step. The Roman Latin from dern languages of Western Europe. the Latin of Romulus.

By this investigation it is found 5th Step. The Latin from the that these 3 parents of the English, Ausonian of Italy.

instead of being remote and distinct 6th Step. The Ausonian from the languages, were themselves brothers, Pelagic of Greece and West Asia. sprung from a common prinitive 7 th Step. The Pelagic from the source, having undergone fluctua- Palangsha or Pali of Central Asia. tions and changes every 500 or 1000 8th. The Pali was a branch of the years. For instance, the Latin of SAnsorit! 
Thus we see all these sources of probably be found a fair averaze of the English language concentrating the mutual rate in the Old Englith; by gradual steps into the $\mathrm{S}_{\mathrm{ANBC}} \mathrm{RIT}$, but the modern has received so many one of the oldest languages of Cen. Latin synonyms as to exceed perhape tral Asis, which has opread its this rate.

branches all over the globe. Being Of these analogies, it is remarkathe original language of that race of ble, that most are not direct from men, fathers of the Hindus, Per- the Latin, or even through the cians, Europeans, and Polymesians. Prenchs but are of Saxon origin,

All the aftinities between English which had them with the Latin preand Sanecrit, are direct and striking, vioualy.

notwithatanding many deviations. Thus the affinities betweon the and lapse oi uges. While those be- English and Greek or Russian, are tween the Engliah and other primi-derived through the Pelagic and tive languagen, auch as Chinese, Thracian, unless lately adopted. Mongol, Arabic, Hebrew, Coptic, Boxhorn and Lipsius first noticed Berler, \&cc. are much less in num- the great affinities of worus and ber and importances beiog probably grammar between the Persian and derived from the natural primitive German dialects: 25 German wrianalogy of those languagea with the ters have written ou this. But WeaSanscrit itself, when all the langua- ton in a very rare work printed at ges in Aeia, were intimately con- Calcutta in 1816, on the conformity nected.

of the Buolish and Ruropean lan.

Many authors have atudied and guages with the Persian, has much unfolded the English analogies with enlarged the subject, and has given many languages; but few if any have as many as 480 conaimilar words beever stated their numerical amount. tween Persian and Latin, Greek, Unleas this is done we can never Englidh, Gothic, and Celtic; but he ascertain the relative amount of mu- hss not stated the numerical ainount tual affinities. It would be a very of these affinities. All this is not surlaborious and tedious task to count prising since the Iranians or Perthose enumerated in Webster's Dic- sians were slso a branch of Hindus, tionary. My numerical rule afiords and this language a child of the Zend, a very easy mode to calculate this a dialect of the Sanscrit. Hammer. amount without much trouble.

- Thus to find the amiount of affinities between English and Latin, let has found as many as 560 affinities us take 10 important words at ran diom in each.

$\begin{array}{lll}\text { Wr. Eng. } & \text { Sp. Eng. Latin. } \\ \text { Woman } & \text { Vumehn } & \text { Femina. } \\ \end{array}$

$\begin{array}{lll}\text { Woman Vumehn } & \text { Femina. } \\ \text { H Water Vuater } & \text { Aqua. }\end{array}$

t Earth Erth

Aqua.

+ God God

Deus.

H Soul Sol

Anima.

One

Uahn

H House Haus

Unum.

+ Moon

Lums.

Star

Star

Luna

H Good Gud

Aster.

We thereby find 3 affinities in captible of 958 increments, as man is $1,395,000$. words may be said to ami afinities marked t equal to 15 exist in this wonderful language.

per cent. more, and 4 words or 40 Yet out of these 2500 roots, as per cent. have no affinities. This will many as 900 are found by Kennedy 
Cair average of Old Englinh; ceived so many exceed perhaps

it is remarkatirect from through the Saxon origin, the Latin pre-

between the r. Russian, are Pelagic and ly adopted.

us first noticed

of worvis and - Persian and i German wrihis. But Werork printed at the conformity Buropean lansian, has much and has given milar worda boLatin, Greek, Celtic; but he merical aunount this is not suranians or Pernch of Hindus, ild of the Zend, crit. Hammer - 560 affinitie 1 Pergian. of Col. Kennethe origin and al languagea of ndon, 1828,4 to. int as directly estigation; not. - has venturéd assertions; and of consequence. at the Sanscrit 9, but only 566 Igs; while each tixes they form is they are susments, as many may be said to ful lavguage. 2500 roots, as and by Kennedy in the Persian and European languages, although the Greek has only these 000 antities

339 are found in the Greek

319 in Latin

265 in Persian

262 in German

251 in Engliah

527 in Greek or Latin

181 in both German and English

31 in all the 5 languages.

This is and Father nof unfortunately no definite, and partly erroneous, as will be proved presently for the Patrin

English. Kennedy denies affinities between the Celtic and Sanscrit, but between the Celtic and Sanscrit, but Feacher amples (only 100) offer man y evident Before affinities. His opinion that the Hin-Wind dus and Egyptians came from the Deity Babylonians is very improbable. It Mouth was from the high table land of Cen- Eyes tral Asia that all the old nations Right caime.

'Th.: 251 English affinities may be Wood seen ii: Kennedy, as well as the 339 Me, mine Latin, which are mostly found now also in English through the words Spirit derived Trom the Latin. These two Being 28 derivated words out of united would be 590 or more alrea- 84 of this old vocabulary. 33 per ct. dy than the 566 separate meanings Another very singular vocabulary of the Sanscrit roots. But Kenniedy I have extracted from the Transachas by no means exhausted the San- I have extracted from the Transacscrit etymologies of the Knglish. thons Although I have no English Sanscrit Ancient Mahabad Religion of Balk dictionary at hand, yet I have many from the book Desatir. Some words Sanscrit vocabulariea, where I find from the book Desatir. Some words many words omitted by Kennedy. are give the And what is not found in the San- Iran, which appears to be a very scrit itself is found in its Eastern early dialect of the Sanscrit and children the modern languages of early dialect of the Sanscrit ant of 30 words 12 have Hindostan.

Among my rocabularies, the most analogies to the English, equal to 40 important is one made by myself of per cent.

the principal words of the old San- Engliwh. " Mahabad therit met with and explained in the Writlen Spoken. Ma Iran

laws of Menu translated by Jones. Father Father, Fiter

In these old and of ten obsolete words End End Antan.

are found the most striking affinities Course Kors Kur (time)

of which I here give the greater part. Nigh Nay Unim. 


\section{8}

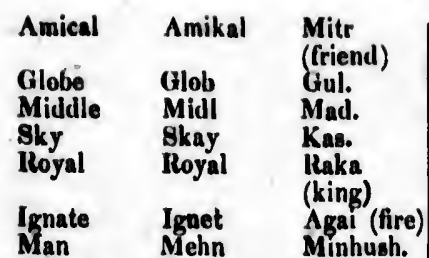

Donation Donesliohn Datisur.

I could add here at least 250 to the 251 of Kennedy, if it were not too tedious and long. But I can safely vouch that all the 566 radical roots of peculiar meaning, forming the base of the Sanscrit, are to be found in the Eunglish roots, or if a few are lacking it is merely owing to some having become obsolete through the lapse of nearly 5000 years, when the Yavanas, Sacas and Pallis separated from their Hindu brethren, and the revolution of 6 or 7 successive dialects formed by each till they met again in the English.

Kennedy has even some obsolete English and Scotch words, now out of use, which are derived from the Sanscrit.

This enquiry is not merely useful to unfold the origin and revolutions of our language; but it applies more or less to all the langusges of Europe: which were formed in a simirope: which were formed in a simiguages. Since every dialect be comes a language whenever it i widely spread and cultivated by a polished nation. Thus the French, Italian, Spanish, Portuguese, Romanic and Valaquian are now be come languages with new dialects of their own, although they are in fact mere dialects of the Latin and Cel tic.

The physical conformation and featurea of all the European and Hindu nations are well known to agrce, and naturalists consider them as a common race. The historical traditions of these nations confirm the philological and physical evidence. All the European nations came from the. East or the West the
of the Imaus table land of Aria, the

seat of the ancient Hindu empires of Balk, Cashmir and Iran. The order of time in which the Ariatic nations entered Kurope to colonize it was as follows, 1 or most ancient. 1. Bsquas or Oscans or lberians or Cantabrians.

2. Gomarians or Cumras or Celts or Giaels.

3. Getea or Goths or Scutans or Scythians.

4. Finus or Iaps or Sames.

5. Tiras or 'Thracians, or Illyians or Slaves.

6. Pallis or Pelaggians or Hellenes or Greeks.

The settlement in Europe of these last is so remote as to be involved in obscurity. But their geographical poistions, traditions and languages prove their relative antiquity. The Greek language is of those that has been most perinanent, having lasted 2500 years from Homer's time to the Turkish conquest. Yet it sprung trom the Pelagic and has given birth to the Romaic or molern Greek dialects. $\rightarrow$

\section{ANTHROPOL,OGY.}

The Fundamental Base of the Philosophy of Human Speech, or Philology und Ethnology.

Br c. S. Rarmeang.

The natural history of man and mind includes so many branches that some of them have been deemed worthy of the proud title of aeparate sciences. Such are Philology or the science of human speech and languages, with Ethnology or the knowleclge of nations of a same speech, which are 80 intimately connected that they can hardly be separated. Ethnology is a very modern science, even later than Geology, and as yet hardly, known in America, although much cultivated latterly in Germany France, being considered an inispensable auxiliary to history and geogrsphy.

Horne Tooke has long ago said inguages cannot lie; and the 6 6: 
Hindu empires and Iran. 'The ich the Asiatic rope to colonize or most ancient. 18 or lberians or

Cumras or Celto

or Scutans or or Sames. acians, or Illyians or Hellenes Europe of these I to be involved eir geographical and languages entiquity. The of of those that inanent, having from Homer's conquest. Yet ?elagic and has Romaic or mo

\section{C. $\mathbf{8 .} \mathbf{R}$.}

\section{POI,OGY.}

of the Philooophy

or Philology and

Imesaty.

ry of man and many branches ve been deemed title of separate Philology or the upeech and lan pyy or the knowa same speech, ately connected 7 be separated modern science logy, and as yet nerica, although erly in Germany onsidered an in $y$ to history and s long ago said not lie; and the ruists have all \\ ए.}

adopted that opinion. Comparative/cardinal numbers in 2 well known phiped that opinion. Confrmed it. languages, Finglish and French, so Phe The resul researches have proved, the unknown, as always deairable in I. That words are the elementa of science.

I have diacovered and applied a a given to the strict formula to fulfil theso indice. mo most common and obvious objects tions, and have thus almost reduced are their first elements, and the least Philology and Fthnology to a matheI 3. That words are the links uni. Synoremic formula, or the Numeriother more or less are the links uni- Synoremic formical Rule. Thus, ting the dialects and languages, into cal and
Prohlem. A number whatever of 4. That these words must be such elementary wurds in two dialects or 4. That the war as apply to the same objects, or are languages being known, to find what
synony mous in many cases. 5. That Syntax and Gramınar or analogy or reciprucal aflinities. the modcs in to the radical or elementary words, alike or similar; their amount is the to the radical or elementary words, alike or similar; their amount is the and thus of much less relative im- numerical degree of affinity when

To these obvious results and rules, given words.

To these obvious results and rules, given words. I add three others which I have $\mathrm{my} \cdot$ Exrtmples. Let 10 words be comself ascertained. words taken almost' at random in If 45 words are compared and ' 20 two languages or dialects, are suffi- found similar, the result is 20 in 45 cient to indicate their degree of ana- $=441$ per cent.

logy, without puzzling ourselves Till now Philologists in comparwith comparing all the words ofling languages had omitted to state both, which

operated. By attending to this imsible.

2. That the degree of aimilarity, portant basis of their labours, we analogy or affinities between 2 or shall achieve a great improvement more anguages ought to be express- and give a kind of mathematical mod numericaly. certainty to the whole.

3. That when needful to pursue I shall not pursue now this forthe enquiry still further or very mi- mula upon the plan of my $3 \mathrm{~d}$ rule, nutely, the deviations or variations 80 as to find the numerical degree of of sounds in the compound words identity of two languages, as it remight be divided into 5 or 10 series quires many explanations; but the of successive or combined changes, mode, problem, answer and examadditions or elision of sounds and ples are upon the same principle. letters; whose numbers should ex- Let us apply it to the cardinal press the analog, and by a division numbers in English and French, $r$. of the total by 5 or 10 , the whole inembering that these two languages numerical and strict amount of iden- are double in form, having each a tity is ascertained. To prove the correct principle of spoken form will be written on the these rules, without enlarging much principles of universal and strict the subject, I shall merely select phonology, as far as our letters and as an example and illustration the signs in use allow it. 
50

Wr. E. Sp. E. Wr. Fr. Sp. Fr. Jcome to the surprising and unex-

One Uahn Un CEn pected result, That all the langua-

Ptwo tu. deux dœ. ges have a greater or lesser affinity

thiee thri trois trua. with all the other languages; which

tfour furor quatre katr'. fact although it may have been sur-

tive faiv cinq senk. mised had never been proved, but

which can now be proved mathe

aeven sev'n sept set.

eight eit huit hoit. very important category or rule.

Pnine naihn neuf nof. $\quad$ That languages and nations are

tten tehn dix dis. no longer 10 be classed or connected

In the 3 numbers marked there by insulated or limited analogies;

is no affinity, in those two ? the but by the numerical amount of their analogy is rather remote.

Thus the English and French lan- other languages.

guages compared merely by their 10 This will be found a great step in cardinal numbers, which are a very the historical knowledge of manfair scale in many languages, evince kind, evolved from the most solid a considerable analogy of 7 in 10 and evident philological proofs. equal to 70 per cent. 'But if the These facts were already partly annumbers 2 and 9 with remote analo-pnounced by me in 1824 and 1828 , gies are only reckoned for 1 , it is and $I$ can now add that $I$ have therereduced to 6 in $10=60$ per cent. by confirmed the unity of mankind: While by the formula of identity, it since even the negro languages have ia still further reduced to 42 in 100 preserved the indications of their or 42 per cent. of positive identity, common origin.

derived from the 3 parents of both In all the American languages $I$

languages, the Celtic, Teutonic and have found -the greatest analogies

Latin.

with the Sanscrit, Caucasian, Arab,

I have been led to this enquiry and Mongol, Samujed and Chinese of mode of investigation, by the wish Asia. 'The Copt, Berber, Jolof, of finding the affinities and origins Congw, \&c. of Africa. The Celtic, of the American nations and langua- Cautabrian, Latin and Greek of Euges, which many superficial examin-rope. And even the Malay, Taers had pronounced to be involved in gala, Japanese, Ha way, \&c. of Polytotal obscurity and impossible to nesia, amounting in some instances classify, but I have not found them to 50,60 , and 70 per cent. of ana80: by $\mathrm{my}$ formula all evince their $\operatorname{logy}$, or from 30 to 60 per cent. of mutual analogies, whose calculable identity.

amount enables us to classify them. I shall conclude by giving one in-

Having further extended this pro-stance of these numerous analogies cess to many doubtful languages of in the Taino of Hayti, Cuba, JamaiAfrica and elsewhere, and-having ca in 1492 and the Guanche of the even compared $S$ languages wití all Canary Islands, now both extinct. the others known, 1. English. 2. The number of words to be comTaino or Haytian. 3. Samang of the pared was 32, and the followiug 14 Asiatic Negros of Malaca; I have|are analogous.

$\begin{array}{lll}\text { Engliah. } & \begin{array}{l}\text { Haytian. } \\ \text { God }\end{array} & \begin{array}{l}\text { Guanche, } \\ \text { Macahuna } \\ \text { Guamochyna } \\ \text { Tuyra }\end{array} \\ \text { Devil } & \left\{\begin{array}{l}\text { Corac. } \\ \text { Achaman. } \\ \text { Achicanac. } \\ \text { Yurena. }\end{array}\right. \\ \text { Land } & -\left\{\begin{array}{l}\text { Caya,Xaya } \\ \text { Acan, Cati }\end{array}\right. & \left\{\begin{array}{l}\text { Haave. } \\ \text { Kaa. }\end{array}\right.\end{array}$




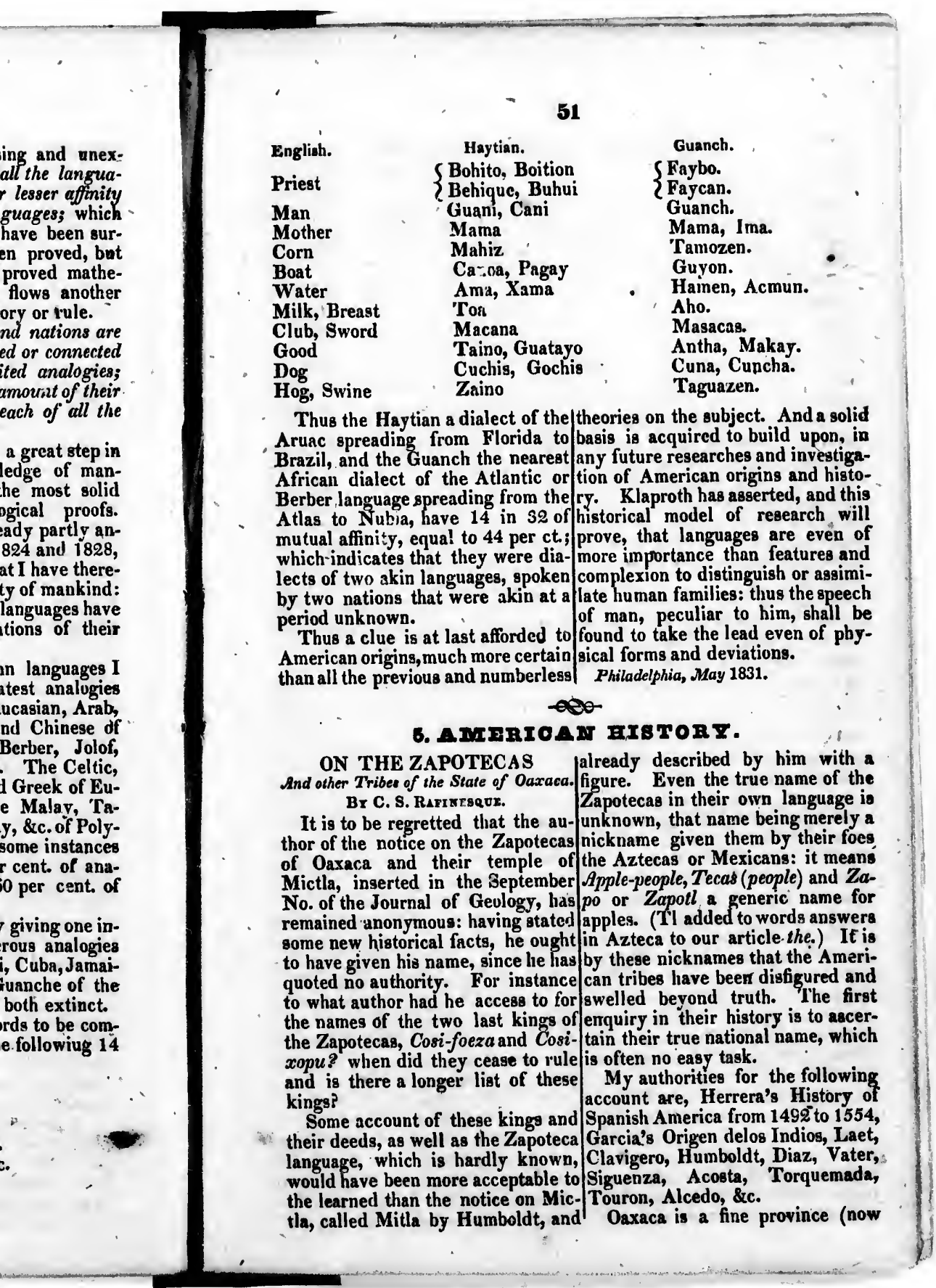


State) south of Veracruz and S. F. IHerrera and Garcias have given of Mexico; it was formed in 1580 some of the traditions of the Zapoby the union of the 2 provinces of tecs.s and Miztecas, neglected by Zapotecas and Miztecas: the name Clovigero and Humboldt. An En. being given by the city of Guaxaca, glish Lord has lately published a formerly Huacryacac and now soft-splendid work on some Mexican enet into Oaxaca, capital of the es- Antiquities and manuscripts. The tate of Cortez, who was made Mar-Library of the Philosophical Society quis of Guaxaca in reward of his of Philadelphia, has the fac simile conquest or rather invasion of Mex- of an Azteca manuscript which I ico. have decyphered.

The Miztecas dwelt between the The Zapotecas boast of being antiZapotecas and Mexico; they were a diluvian in America, to have built fierce nation, yet at war with the the city of Coutlan (snake place in Spaniards and Zapotecas in 1572, Azteca) 327 years before the flood, and only subdued between 1572 and to have escaped the flood with and 1580 (Laet). Their name has their king Petela (Dog) on the mounbeen spelt also Mixtecas, Miclec, tain of Coatlan (Garcias.) Which Mixes, Mixos, Micos, Mecos, Miges, of the two floods of the Aztecas this \&c. All these names, leaving off was, whether that of Xellura or of tecas which means people, imply Coxcox is hard to say. The Petela Lion or rather Cuguar, are animal or Dog dynasty ruled over them ever of the tiger genus, which was the since till the Spanish conquest. emblem or progenitor of the nation The Coatlatecas (snake people) (Miz tiger genus in Azteca.) But the or Cuitlatecas, the Cuycatecas (singMexicans changed it by contempt ing people) or Cuiscatecas, and the probably into $M i c, M i x$, or $M e c$, a sin- Popaloavas are tribes of Zapntecas, gle word meaning 4 things in Azteca, speaking dialects of the same lanwhich are connected in the language, guage, of which Clavigero says there 1. Nonth, 2. Hell, 3. Devil, 4. Apes, is a grammar, but Vater has not giThis is evidently the root of Mictla, ven any words of it. I have been tha being the article or an abbrevia- able to collect only 12 words of it tion of tlan a place.

It is bJ this apparently out of 6 authors. God or Creator examen and etymology that $I$ have of all things come to the important conclusion that Spirit Vinac the Miztecas and Zapotecas are the House or ? modern remains of the ancient na- place $\}$ tions of. Olmecas and Xicallancas, Brother mentioned in Mexican history as Dog anterior to the Toltecas in Anahuac; Repose or and that the Otomis and Chichime- Death cas were also consimilar tribes. Here it will be needful to refer to Earth ancient traditions, which are not all Hell or lost. Although, Zumarag not all Hell or bishop of Mexicu, and extulled for Woman an Yxca. his zeal by the monks, behaved in Eve or first Woman "Xtmana. Mexico as Omar had done in Egypt, Adam or first Man Xchmel. by burning the libraries of Tezcuco, Whereby it is seen that out of 6 the Athens of Anahuac, (those of words which I have to compare in Mexico itself had been lost in the Mizteca 4 are similar and 2 not very siege) he could not destroy all the different. Therefore the just conbooks scattered through the whole clusion is thai the Mizteca and $\mathrm{Za}$ of Anahuac. Many are yet extant, poteca are also dialects of each oth- 


\section{3}

have given f the Zapoeglected by t. An Enpublished a he Mexican ripts The I cal Society e fac simile ipt which I

f being antihave built ake place in re the flood, c flood with on the mouns.) Which Aztecas this elhua or of The Petels er them ever nquest.

ake people) atecas (singcas, and the Zapotecas,

e saine lan rosays there - has not giI have been words of it

hcabohuil.

n Mizteca.

ua do.

do. levui do. agnuay do.

chi do.

tmana.

chmel.

it out of 6 ompare in 2 not very

just con-

sa and Za-

f each oth- er, or languages very nearly related. Snake-men, Dog-men and Cat-men The same with the Zacatecas. or people.

Of the Mizteca Vater has given The Olmecas or Olmec or Hulmany words; he surmises that it is mecs of ancient Anshusc, whose very near to the Othomiz or Otomi: name neans Old Devils in Aztecs, and he considers several other lan- are said to have settled in Anahuac gugges of Anahuac as dialects of it: after the Othomiz, but with their they are the Zoque, Lacandone, allies the Xicallaneas or Xicayans, Mame, Zeltales or Celdales, Chia- whose name we may recognise in paneca, Mazateca, Chochona, be- the Cuycatecas of modern times, and sides the Mixe and Cuiscateca al-were probably the old Zapotecas, ready mentioned. This if true the Southern Miztecas are yet called would diminish the number of lan- Xicayans.

gusges of that region and extend the Their settlement is so ancient that Mizteca nation far to the South and it is beyond the Azteca and even Esst in Guatimsla, as the Otomi and.Tolteca chronology. It happened Chichimecas will extend it far to the after the sway of Gods, Giants and North.
Apes (different nations.) They con-

I have a good rocabulary before quered and expelled the Giants or me of the Othomiz language by De Titans of Anshuac called TuinameNeve 1767, and although only 10 tin and Tzocuitlixeque, and tonk words can be found in the Miztecajthe name of Tequenes or People of of Vater, 5 of them are alike or simi- Tygers. They were divided into 3 , lar, which gives 50 percent of mu-tribes, Olmecss, Xicalans and Zaca 1 . I affinity and leaves little doubt tecas speaking the same language! ir primitive connection. These (see-Torquemada.) They came from u. is re

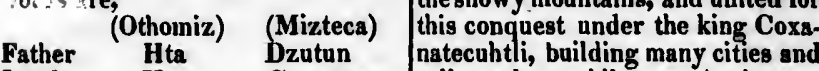
Land. Hay Gnuagnay. ruling a long while over Anahuac. Nose Xinu - Dztni. Son Batzi Dzaya. of the Hulmecns to Hulmecatl broBread Thume Dzite. The Chichimecas (Dog devils or ac, and indicates several dynasties Northern Dogs in Aztecas) are not ruling successively their empire, 1. a nation, but this appellation was Ulmec, 2. Cochoblam, 3. Quetzalgiven to all the northern wild tribes coatl, the famous Legislator of Choand foes of the Axtecas, even to one lula, t. Huemac, and ends by Colospeaking the Azteca language, and pecthtli last king killed by the Tlas. lately to many of the Apaches, Skere calans towards 1196 of our era, who or Pani tribes forming a nation drove them to the East settling in spread from Anahuac to Oregon and their country. The last we hear of Athabasca lake, among which the the Ulmecas in the Aztec history is Shoshonis of Oregon bear also the in 1457 and 1467 when those of Coname of Snake Indians as yet. tasta on the ses shore were conquer-

In result I am letl to believe that ed by Montezuma I. While this the Miatecas and Zapotecas were name disappears from history, that once with the Otomis and many of the Miztecas and Zapotecas ap. others, the snake nation of America, pears in the same place or to the $s$. which did afterwards divide into the $\mathrm{E}$. of Mexico, and thus the evidence Dcg and Cat tribes or Zapotecas and is complete that they were the same Miztecas. The same has happened nation under different names.

in Asia and North America where In 1454 the Miztecas won a great many nations ascribe their origin to battle over the Aztecas and their al- 
lies, whose real sway in Anahuac/thoee of the remainder of North only began towards 1425 and hardly Ainerica.

lasted one century. In 1455 Ato- The Theogony, Cosmogony and naltzin king of Miztecas although religion of the Miztecas and Zapohelped by the Tlascalans was taken tecas was also very different from and his kingdom conquered. 'This the Mexicans, although they had king is elsewhere called Yaguitlan. latterly adopted their blnody rites of

The Miztecas rebelled in 1480, the god of evil. The 'Miztecas of and in 1486 the Zapotecas resisted Cuilapo according to a book written the whole power of Mexico. But at by a Spanish monk in the Mizteca last became tributary; yet in 1506 language and figures, (preserved by and 1507 they both were at war again Garcias) ascribe their origin to a god with Mexico.

and goddess named Lion Snake and

Although overjoyed at the down. Tyger Snake dwelling in Apoala or fall of the Mexicans, effected by heavenly seat of Snakes before the 100,000 Tlascalans and allies amiong flood. They had two Sons '(or nawhich.were gome Miztecas, and 900 tions) an eagle called $W$ ind of 9 Spaniards under Cortez: they did Caves, and a Dragon or Winged not readily submit to the Spaniah Snake called $W$ ind of 9 Snakes. yoke and tribute after the fall of They were driven from Apoala for Mexico in 1521 .

In 1522 the Zapotecas defeated Sandoval, and were only conquered their wickelness and perished in a in 1526 by Olmedo (see Diaz, but cans: which is perhaps the Apalach they have often rebelled against the mountains of North $A$ merica, where Spaniards. In 1572 the Miztecas was once the holy mountain, temple were at war with the Spaniards and and cave of Olaimi (see Brigstock) the Zapotecas; these had been con- which name recalls to mind the ciliated by the mild rule of their Olmecas! and all these names anLord Cortez, who establighed only swer in import and sound to the a small quit rent on land, without Olympus of the Greeks.

any forced labour: this system has The Zapotecas had similar but made Oaxaca a flourishing city and more definite ideas. Ahcabohuil province.

was the Creator of all things; but a The Zapotecas and Miztecas are divine man and divine woman representel as the handsomest In. Xchmel and Xtmana were the prodians of Mexico, nearly white, and genitors of mankind and of the 3 the females are beautiful, as white great gods Avan god of heaven, Bace as the Spanish women. This also god of earth and Chevan god of hell. happens in Zacatecas, a province of These 3 brothers are surprizingly the former Olmecas: therefore it ap- alike in import and names with the pears that this race is distinct from Trimurti or triad of the Hindus, the the Azteca or Mexican nation in 3 manifestations of the Deity $V$ ish features aa well as languages: not-nu, Bramu, and Shiven!

withatanding that -some writers This same triad was worshipped wrnngly assert that the Olmecas in Chiapa, Yucatan, Hayti and many spoke the same language as the Az- other parts of America, under names tecas and Toltecas. The Mires not very unlike, such as have sometimes long beards and re- Izona, Vacah and Estruah in Chi semble Furopean; they are a tribe apa.

of Miztecas. Thus we find by in. Izona, Bacab and Ectivah in Yuveatigation that the nations and lan- catan.

guages of the Mexican States are as Bugia, Bradama and Aiba in eavily reduced to a small number as Hayti. 
Iao, Isnez and Suroki by the Hum, Fo and Kya, of Thibet. Apalachians. $\quad Y, H i$ and $V i$ of the Tao religion Yah, Wachil and Wacki by the of China.

Natchez. $\quad 0, M i$ and To of the Fo religion of Qunyoh, Kiwas and Ocki in Vir- China.

ginia and Florida. . Eon, Hesu and Pur of the PhryZungua, Quexuga and Haraqui by gians.

the Chicolas. Garronhia, Tahuisca and Oyaron Syrians.

by the Hurons.

Amane, Vaca and Vochi by the Amon, Mouth and Khous of Tamanacs.

Akambue, Ichein and Maboya by Gcharan, Ahicanac and Guayota the Caribs.

Apu, Churi and Voqui in Peru. Pillian, Meulen and Wocuba in Chili.

Nemque, Zuhe and Bochica by the Muyzcas.

Guipanavi, Avari and Caveri by Pan, Eros and Methusa, of the the Maipuris.

Aygnan, Tupan and Mabira in Zeus, Poseidon and Hades of the Brazil, \&c.

Are not these coincidences very Ian, Aesar, and Sancus of the surprizing anil interesting for the Ftruscuns.

history of mankind and of their re- . Ain, Aesar and Taut of the Celta. ligions? They will appear still more Bram, Amen and Vix of the $\mathrm{O}_{4}$. so if we compare them with the dif- cans.

ferent triads of $A$ sia and other parts. Kog; $O \mathrm{~m}$ and Pax of the EleusiSometimes the Asiatic names are nian mysteries.

more dissimilar between themselves Molk, Fan and Taulas of Hiberthan the American, or else resemble nians.

still more some of them. A few in- Odin, Vile and Ve of Scandinastances will be sufficient to prove vians.

this strange fact. Asiatic Triads.

Brimhia, Vistnow and Etcheves.

Tama, Satua and Raju.

Prainih, Bichen and Sumbreh.

Angeor, Okar and Gun.

Braham, Narayan and Mahesa.

Brahima, Bala and Mahadeo.

Brumany, Ramana and Rudra.

Primah, Krishna and Iswara. The above by the Hindus in festations is of little consequence different modern anguages of and lepends upon the priority of India, Decan, and Indostan: those mostly worshipped, whether which are all dialects of the the God of Heaven, Earth or Hell. Sanscrit. The Hindus have now two Secte

Prahma, Aug and Codon in Sism. worshipping Vishnu and Shiva, but and Ava. Bahman, Homi and Barzoi of sent.

Iran. These names would appear etill

Bahman, Manistar and Tamiatar more strikingly alike if they all of the Mahabad. Imeant the rame; but thej often meen 


\section{6}

the past present and future. or power, yet apoken languages, and some are life and death, or the rising blazing but dialects of those above. 1. Utand setting of the Sun or soine other lateca. 2. Cohuichi. 3. Tlahuichi. consimilar ideas instead of heaven, 4. Zoque. 5. Mame. 6. Chiapaneca. earth and hell, although they always 7. Chochona. 8. Mazateca. 9. Cuisapply to the triple manifestations of cateca. 10. Popaloava. 11. Tubar. the Deity distinguished and person- 12. Yumas. 13. Seres. 14. Moba, ified in Creation, Preservation and \&c. Besides many clialects of CaliDestruction. This subject which fornia, Texas and New Mexico.

might be pursued much further, may Although they may be mere diaindicate a primitive conformity of lects it is needful and desirable to religious ideas in mankind all over have materials on each, so as to rethe world.

duce this to a certainty and to trace

Seventeen languages and dialects their mutual analogies or deviations, of Anahuac or the Mexican States as well as the probable time of the are said to have been reduced to separation of the tribes.

grammars and dictionaries by the These 40 Mexican dialects will Spanish missionaries; Vater and the thus be reduced very probably to 5 other philologists do not appear to or 6 primitive languages, as thope of have known them all. In order to the United $S$ tates have already been draw thereon the attention of those reduced to seven, the Onguy, Lenih, who dwell in Mexico, I shall attempt|Chactah, Otaly, Capaha, Skere, and to enumerate all the Mexican dia- Nachez, by inyself in the manuscript lects under 4 series, 1 well known, history of the American nations. 2 Little known, 3 Hardly known And in the whole of North and South and 4 Totally unknown to the learn- America hardly 25 original languaed and historians. It will be obvi-ges and nations are met with, alous that the $\approx$ latter series require though actually divided in 1500 chiefly the attention of those who tribes and dialects; as the actual may have the opportunity to travel European languages, only 6 in numor dwell in Mexico.

European languages, only 6 in num
ber originally, are now divided into

1st Series. Languages or dialects 600 dialects, some of which are even well known of which we have ample deemed peculiar languages at prevocabularies and grammars known sent.

to the learned-1. Azteca or true 'Thus these original or mother lanMexican. 2. Otomi. 3. Mizteca. guages of Europe are the Pelagian,

4. Maya. 5. Cora. 6. Totonaca. Celtic, Cantabriau, Teutonic or 7. Pima 8. Poconchi. Gothic, Thracian or Slavonian, and 2d Series. Little known to the Finnish. And out of the Gothic learned at least, but well known in have sprung the English, Dutch, Mexico as there are grammars \&c. German, Danish, Swedish, \&c. of them: 1. Tarasca. 2. Huasteca. which were once mere dialects, but 3. Yaqui. 4. Popoluca. 5. Matlazin- are now become languages having ca. 6. Mixe. 7. Kiche. 8. Cachiquel. many dialects of their own.

9. Tarahumara. 10. 'Tepehuanan, \&c. Of these I have procured al$\rightarrow$

6. History AND Zoology. ready ample vocabularies of the two ready at rst.

3d Series. Hardly known, of wich we posess as yet but few vords. 1. Zapotecas. 2. Zacatecas. 3. Chol. 4. Chontal. 5. inda. 6 . Opata. 7. Endeve. 8. Qut \&c

coming subservient to their use; by lack of materiala, althow t t $t_{-}, \vec{j}$ are or kept in chains and cages.

Domestic Animals of Mankind

I mean by domestic animals those which have been tamed by mankind, and dwell in freedom with men, be no 
ind some are

ove. 1. Ut-

'Tlahuichi

Chiapaneca

ca. 9. Cuis-

11. Tubar

14. Moba

cts of Cali-

Mexico.

e mere dia-

desirable to

so as to re-

and to trace

deviations,

time of the

lialects will

obably to 5

, as thope of

Iready been

guy, Lenih

Skere, and

manuscript

in nations.

$h$ and South

inal langua.

et with, al-

in 1500

the actual

y 6 in num.

livided into

ch are even

ges at pre-

mother lan-

e Pelagian;

eutonic or

ronian, and

the Gothic

h, Dutch,

dish, \&c.

ialects, but

ges having

n.

OLOGY.

Mankind

ations.

U1.

imals those

mankind,

h men, be-

eir use; by

'e pursued

The lomestic the prinitive and ancient nations of animals has always been deemed a America.

animals has always tables atandard of civilization, and the cultivation of plants is another.

The slanderers of the American Continents, and afterwards quote The slandson included) have my authorities for those of America; nations (Roriso any since in the actual state of our not been willing to perceive any since in the so much that res to high civilization in this continent, knowledge, so much that relates to and have totally overlooked the nu- America is endeavoured to be formerous animals they had domesti- gotten, that it becomes neediul to cated. cated. In America the number of domes- thors which ourd, consult and adopt. tic animals was greater than in too lazy to read, consult and adopt. Asia, Europe and Alrica! this asserAsia, Eubreviations in '... s.able. tion is fact, which I shall presently prove N. A. North America. Europe. completely. I do not mean to in- S. A. South America. clude among the domestic animals $W$. I. West lndics. Af. Africas of this Continent those introduced M. Mexican States. P. Polynesia. of this being intended as a popular since 1002 by the common nor since 1492 by the Spaniarils; Essay, I slati give the

2 T TBLE.

Domestic Animals of America. $\quad$ Domestic Animals of Asia, Europe, Africo

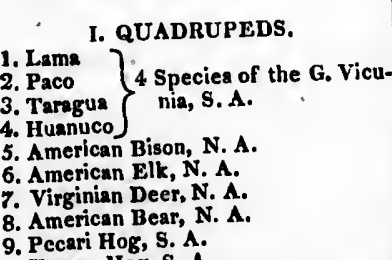

9. Pecari Hog, S. A.

10. Tayasu Hog, S. A.

11. Dog-

12. Aguti

$\left.\begin{array}{l}\text { 13. Cavia } \\ \text { 14. Paca }\end{array}\right\}$ different genus. S.A. \& W.1.

15. Huti $\int$

16. Tapir, S. A.

17. Capibara,

18. Coati, $M$.

20. American Badger, N. A.

32. Flying Squirrel, N. A.

33. Manati or Sea Cow, W. I. and S. A.

$$
\text { 2d CLASS.-BIRDS. }
$$

1. American Hen, N. and S. A.

1. Musky Duck, 8. A.

2. Muaky Duck, 8 . A.
4. Powis or Agami Domestic Fowla of

4. Powis or Agami Domestic Pow

5. Hoco

and Polynesia.

1. Common Camel, A. E. and Af.

2. Bactrian Camel, $\mathbf{A}$.

3. Common Ox, A. E. Af.

4. Buffaloe, A. E. Af.

5. Asiatic Elephant, $A$

6. Horse, A. F. Af

7. Aas, A. E. Af.

9. Hog, every where.

0. Dog, (15 varielies) do.

1. Cat, do.

3. Rabbit, E.

6. Wacarara

8. Cocolin Quail, M.

5. Sheep A. E. Af

16. Goat A. E. Af.

7. Antelope A Af.

Yali or Thibet Cow, $A$

19. Reindeer, E. A.

20. Ounce, $\mathbf{A}$.

1. Marmot, E.

23 to 25.3 ap. Monkeys in Aaia and Af.

2d CI.ASS.-BIRDS.

Hen, every where.

2. Pidgeon, do.

3. Goose, do.

5. Swan, do. rare.

6. Guinea fowl, Af. $E$

7. Peacock, A. E.

8. Pheasant, A. E 
9. Amerioan Crane, N. A. 10. American Pidgeona, N. A.

11. Camada Goose, N. A.

12 to 25. Parrota $14 \mathrm{sp} . \mathrm{s}$. $A$. and $W . L$ 26 to 28. Ducks 3 ap. in Brazil and Pe

ru and $M$.

9. Partridge, $\mathbf{E}$.

10. Quail, k.

11. China Diver, $A$.

29. Americen Oatrich, S. A.

30. Flamingo, in Cuba.

31. Ringdovea, N, A.

22. Carib Gonae, W. I.

3d CI.ASS.-IEP'TILES.

1 to 5 . Land and Water Turtles, 5 ape cies, $\mathbf{s}$. $A$.

5 to 8. Iguanas, 3 apecies.

9. Rattle Snak

to 15. Harmleas Snakes, 6 sp. M. and 8. A

4th CLASS.-FISHES.

1. Remora, W.

2 to 12. Pond Fishes of M. Guatimala, Peru, \&c.

5th CLASS. INSECTS

1 to 3. Bees, 3 sp. S. A.

4. Red Cochinille, $M$.

5. Monteres or Yellow Cochinelle, $M$.

6. Silk Worm of Miztecs, M.

8. Termes, S. A.

6th CLASS.-SHELLS and WORMS 1 to 5 . Oyatera, 5 kinds, N. and S. $\Lambda$. 6 to 10. Clams and Sliells, 5 sp. N. an

$$
\text { s. } A \text {. }
$$

11 \& 12. Palm Worma, 2 ap. S.A \& W.

RECAPITULATION

33 apecies of Quadruped

32 " Birds.

15 Reptiles.

8 “ Fishes.

12 "

112 Species in America.

to 19. Partoto, 8 ap. A, 6.

20. Dove, A. E.

21 to 25. Falcons and Hawks, 5 ap. A. E.

3d CLASS.-REPTILES

1 to 3 . Land Turtea, 3 ap.

4 to 10. Snakea, 7 ep.

4th CLA8S. - FISHES

1 to 10. Sp. of Carps, and Pond fishea Gold fish, \&e. China, A. B.

Sth CLASS,-INSECTS.

1. Honey Bee, A. E. Af.

3. Kermes, $r$.

4. Pig Cynipa, E.

6th CLASS,_SHELLS and WORMS.

1. Oyaters, $\mathrm{E}$.

3 to 5 . Other Shell Fish, $\mathbf{E}$.

6. Pinna or Biasus, $\mathrm{F}$.

\section{RECAPITULA TION.}

25 species of Quadrupeds.

25 " Isirds.

10 " leptiles.

10 "1 Fishes.

4 "I Insects.

80 species in the other Continent.

Such a great number of domestic Fuhites 300 years after the flood of animals were not collected every $Y_{11}-\mathrm{ti}$ or Noah, which were the where; but a small number founl in horse, the ox, the sheep, the dog different localities in America and the hog and the hen. elsewhere.

The domestication of animals be. gan before the flood, since the $A b e$ lites or Pastoral tribes, and the $\boldsymbol{C a}$ The other animals were gradually - and limited range, such are of local bulites, Cabils, or Cainites, agricul- Reindeer to the Boreal Regions. tural tribes had at least reclaimed Europe has only received the the sheep and the ox soon after loe and Camel lately from Asia; and Adam. Yet in the earliest Chinese since 1492 some of the American history only 6 domestic animals are domestic animals have been introotated to have been reclaimed by the duced there. Such o then intro. 
A. 6.

Hawks, 5 op. A. E.

EPTILES .

3 ap.

-FISHES.

$y$, and Pond fishes

ina, A. E.

INSECTS.

Af.

L9 and WORMS.

ish, $\mathbf{E}$.

LATION.

peds.

er Continent.

ifter the flood of vhich were the sheep, the dogr 8 were gradually ome are of local uch as Yak conrrret to Europe, Boreal Regions. :eived the Buffa$y$ from Asia; and of the American ave been introas the Cavia,
Turkey, Musky Duck, and several|rolina towards 1700, says that the Congaris and Wateris had tamed arrots.

In America the 4 kinds of Vicu- the American crase nia or Peruvian sheep were spread kind of silkworn to this very day, by the Peruvians to Chili, Pucu- kind Poinset: it is a native kind.

man, Paraguay, \&c. and the Dog see Poinset: it is a native the beautiful was found every wheres while the In the West Indies, the beautiful domestic Tapir, Tayasu and ruber had been tamed in 1494, in were confined to some small tracts puber had been tamed large parrots, in South America. The common Cuba; also fish the Remoin or EchVirinian deer is found wild all over and even a fish the Reer North America; but we hear of its eneis which was used by the fisherNorth Am inen to catch turtles and fishes by domestication only in Florida. Inen to catch turtles and hadso tame

Let us detail the proofs of the grasping them. They had also tame American table drawn from the ear- partridges and iguanas in 1508 . Sulumbus, Diaz, Ocampo, Acosta, liest travellers and writers on this Colu continent. The domestic animals \&c. continent. In Hayti they had tame iguanas, of the Mexicans were several kining or sea cow, and aeveral of dogs, deer, fowl, ducks, cocolin, manats of rabbits or agutis. They turkey, snakes, fishes, cochinille, kinds of rabbits or agute. \&.c. See Cortez, Lerrern, Clavigero, also used the light. See Columbus, and all the writers on Mexico.

The Taensas, Cenis and other na- Martyr, Acosta, Munoz, \&c. tions of Texas and Louisiana, liad Several tre bear, the raccoon, tions turkeys, ducks, hens, pidgeons have tamed the bear, the raccon, tame turkoys, 150 years ago, when the badger, and keep them in their and ringdoves, 150 years ago, when houses to this day. The flying independent, see Lasalle, Tonty and louses to a common pet with the - Hennepin.

In 1678 the Chicasas had tame boys and girls. Indian hens and turkeys, see Ton- In Guatimala and monkeys were ty's travels. In $\mathrm{Xalisco}$ to the N.W. of Mexi- tamed and kich anecies they co, several anakes were tamed and are seldom told which apecies they cept in the houses, to destroy in-were. The Aruwacs of Guyana dekept in the houses, of Mexico the light to keep the beautiful little sects. In other parts of Mexico tie light to called sucawin, not larger beautiful coral snake was kept as a monkey called sucawin, not larger

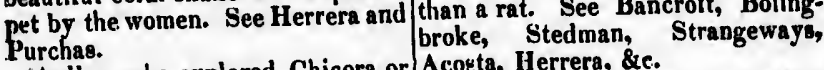
Purchas.

Ayllon who explored Chicora or Acosta, Herrera, \&c. Chicola the eastern part of Florida In Darien and Yucatan the like hog now Georgia in 1514, \&c. found herds of tame pecaris ke be 1540 there tame ducks and geese, and according to Herrera, before 1540 . besides deer kept like cattle in folds The Epurimei of Guyana kept during the night, ranging out in the tame pecaris, fayasus, and deer. See during the dight, ranging deer must be differday, returning home in the evening; Purclias. This deer must be difin and the does were milked like goats, ent from the Virginian deer

and the Indians drank the milk. See must be added to the table. A yllon's relation in Peter Martyr d' The 4 kinds of tame fowl of GuAngleria. yana are mentioned by Waterton; The first Spanish explorers of but they are spread under other New Mexico or Cibola found the names as far as Guatimala and BraNison in zil.

fison or Arfolds and pens, like cows. Dce Her- uasas of Brazil with tame geese, rera, Hackluyt, \&c. 
the tapir or anta had been tamed by The partridges of Maranon have them. He found also the patagons been omitted in the tnble. 'Tliey with taine huanaces. tamed the ostrich, also geese and parrots in 1493 at Guadalupe when hens before 1550. See 'Techo.

Four species of rabbits, Puca ni- In Chiapa a yelluw cuchinille is gra and Paca fulva, Cavia aguti rnised called monteres; see Juarro. and Cavia acuchi were domesticated The true cochinille of Oaxaca and fron the West Indies to Peru and E. Mexicu is well known. The same Paraguay, inder various names, or a dlifterent kind is also found in Capis and Cuyres in Peru, Papos on Guatimala and Gunyaquil.

the Maranuin and among the Guara- In Collot's travels I find that the nis as early as 1534. Quinaxes in Alitans or Snake Indians of New Quito, Aperea in Brazil, Hutia in Mexico, keep tame rattle-snakes, Hayti, \&c.

which they venerate, and feeding

Dogs wore found from Canala to them on flour only, they lose their Chili; some peculiar varieties exist. poisonous property! this is strange ed: the alco of Mexico had no hair lif true.

and was very good for fool: the The capibara is tamed in Brazil, aperuca of Pelu was a black dog. the conti in Guatimala, the American

The Muras or Aymores of Brazil elk is easily kept in parks anil folds. and E. Peru had many kinds of tame The beaver alone, so useful and so fowls and ducks. Acuna mentions sociable, has never been tamed, but that 200 years ago the tribes of $\mathrm{Ma}$ - wantonly destroyed.

ranen had tame turtles, manati, anta Sume Indian tribes took care to or tapir, pecari and paco.

Sume Indian tribes took care to

Or the five species of Vicunin, the oysters, muscles, clams, \&c. 'The Peruvians had tanied 4, the true palm worms esteemed a delicucy in mountain Vicunia alone remaining Guyana were taken care of, as well wild and untamable. They were as 3 kinds of bees. See travels in used as beasts of burthen, for wool South America.

and food. Sometimea even as horses The result of this Enquiry will be to ride upon by the Achkeres of that more aninals have been tamed West Brazil in 1540 and the than we were aware of, particularly mapais, or mbayas of tucuman in America, and that the Americans in 1548; they called the laina had little cause to regret lacking the by the name of Amilas. The tribes horse, camel, ox, sheep goat and of Claco had in 1548 tame deer, hog, since they had for equivalent lama, geese, and they cultivated a the vicunias, deer, bison, pecarris, kind of wheat and of rice. See Gili, tapir, \&c.

Lozano, Iavega, Schnidel, Pur- I have long been convinced that chas, \&c. Cundions, such as the Toltecas, Mexikept the large ants or termes in cans, Turascas, Apalachians, Mayyards to breed, using them to inake ans, Quiches of North America, and kind of bread. See Piedrahita and the Muhizcas, Peruvians, AraucaTouron. The Carios of River Parana had low as represented by their tyrants tame lamas, pecaris and geese in and detractors; but equal if not su1539; see Schnidel's Travels.

perior to that of the Spanigh invaders

The Chilians, Araucas and Hue- of 1492: which fact will be easy to nus or patagons had tame guanacos demonstrate; but this is neither the and goats: they cultivated 2 kinds time nor place. I have merely ilof wheat.

lustrated one of the many proofs of 
aranon have able. 'They those of $\mathrm{Cu}$ he geese and lalupe when s.

cochinille is see Juarro.

(Oaxaca and 1. 'I'lie same so found in ii.

Ind that the ans of New ttle-gnakeg, nd feeding lose their $s$ is strange in Brazil, e American $s$ anil folds. eful and so tamed, but

ook care to sters, pearl \&c. 'The delicacy in of, as well travels in

diry will be een tamed articularly Americans acking the goat and equivalent - pecarris,

nced that American

:as, Mexiins, May: erica, and Arauca. as not 80 ir tyrants if not suinvaders e casy to ither the nerely ilproots of their civilization, by introducing a in 1802, it diflers from the European subject which had been overlooked kind, which I have seen in Europe, by all, even Ilumboldt, and Macul. by tail one seventh of whole length, lolı.

'Two species of deer, the Mexican and Guyann deer must be added to fulvous. The European mole may the table, also the Puda goat of Mo-be found somewhere in North Ame. lina tamed in Chili: and 5 species of rica, but I have never seen it.

bircls, the partridges of Cuba and III 1820 I described in my Annals South America, besides the Ameri- of Nature, sp. 5 . the spalax vittata, can swan and pelican, both of which with striped back, \&c. 'The comI have seen domesticated. Thus pilers who seldom travel and neglect the American domestic animals will the published labours of travellers be increased to 120 species. I have who have wandered in search of also seen buffalies, elks and decr in knowledge; have not noticed theso parks in Kentucky, in fiecdom, yet two species. 'This last however has cuming at the call to be fed with been also seen by $\mathrm{my}$ friend Auducorn or sait, and never endeavour- bon, who first made it known to me, ing to cacape from a park merely and is inserted in the English Jour. surrounderl by a common fence. nal of Zoology of 1822. The G. Such. was the park of Col. Geo. spalax of Erxleben contains the mole Thompson at Shawanee Spring near rats without tails.

Harrodsburg.
Mr. Harris of Maching in Maine, $\rightarrow \infty$

7. ZOOLOGY. singular inole of that State, which

On the 7 . ZOOLOGY. two new species from entucky. mycter prarinatus. Not being yet Hx C. S. Harixesuve. introlluced in the books of compilers, 'The moles like many of the amall I'll give a short account of it. $\mathbf{G}$. quadrupeds of this continent, are astromycter. Snout stellated, noezhardly known and distinguished as ternal ears, eyes small, legs phort yet. Several of them have been 5 toes to each, anterior scaly with inixt in the genera talpa, sorex, sca- long strait claws, posterior longer lops, spalax, condylura, \&cc. of the with shorter curved claws, tail acaly, naturalists. In Harlan Fauna Ame- fusiform, with thin hairs.

ricana the G. spalax is omitted, as Sp. A. prosinatus. Hair glossy well as the tuzan of Mexico and green, snout naked long with cartiLouisiana, and the N. G. lately dis- lagineous stellated processes; and covered in Maine. He has only one two others longer before: tail pedunmole or talpa of North America and culate, fusiform, cylindrical, acute, he deems it the 'T. europea saying in two fifths of whole length; body $4 \frac{1}{2}$ the character fur black, and in the inclies, tail 3 .

description fur cinereous, fan on the In 1820 I discovered two new throat, \&.c. and then he has 4 varie- moles in Kentucky, one is rather ties spotted, white, yellow and cine- cominon and the substitute of the reous again.
coinmon mole in the gardens. I call

All the animals burrowing and it talpa macrhino. The other talpa raising the earth in ridges are sericca is rather scarce. A specimen called moles in the vulgar language: was in Clifford's museum.

although they may not all be talpa; 1. Talpa machrina, Raf. 1820.the shrews are the G. sorex.

In 1814 I distinguished one of the with greyish shades; nose elongate, moles found in the Atlantic States depressed, naked and tuberculate; by the name of talpa cupreata tail one sixth of whole length white, (precis. sp. 7.) which I had obwerved squared, naked, feet white. 
'lotal length 7 inches, tail If but, obtuse, not sharp nor crooked; while only f nut of the fur. Body thick, they are so in the other otters. covered with a soft silky fur inch Lutra concolar. sp. cl. Entirely long, shorter and woolly un the head, of a uniforin bny color, tail deprossnose almost like a proboscis of inch ed as long as the body, claws blunt. longer than the lower jaw, moveable, Deucription. - Total length $2 \mathrm{t}$ is: bave white villose, and naked rubi- head and neck t, body and tail ench cund, feet naked, the anterior brond, one fout; nose blackiah, no whiskers, rounded flat with 5 toes thick ancl cars very small; six small close insubpalinate or cuherent, 5 claws cisores to each jaw, canine teeth nearly equal, iarge, convex above, large, grinders slarps feet short, flat beneath; posterior feet more with 5 unequal palmate toen, and slender, claws sumaller, longer and claws aa above atated; tail slender narrow. In woots, gardens anil fiat acute.

fields, near Lexington, \&c. Raises Found in Assain and the Garrow Gexuose burrows of great length hills. Dwells mostly on land, seldom 2. Talpa scricea. Raf. 1820. Silky goes to the water; feeds on fish and mole.-Fur short silky, grey, with fowl. C. S. RAr
Philadelphia, 27 March, 1832.

silvery sliades; nose short obtuse tail on

P. S. Dr. Burrough has again

sailed on another voyage to Buenos

Smaller than the firat and mare Ayrea and China, from whence he slender, only 5 inchea long, body 4 will no doubt bring many rare ob-

and tail 1. Fur very peculiar and jecta of Zuology.-May 1832.

different from the other moles, not being reslucible to different directions; but imbricate as in other quad. rupeds remainder as in the first sp. Found in woods near Nicholasvili and Harrodsburg. $\infty$

9. Covouna of Orteon. By C.S.R. In addition to the article on our Couguars, p. 19, I have to atate that several other varieties of tygers are found in the Western wilds of the 8. Description of a New Otter, Lu- Oregon Mta, or East and Weat of Tus Convolor from Assam in them, which deserve to be noticed. Asia. I find in my notes that two other Dr. M. Burrough of Philadelphia, varieties of Cuuguar have been seen has been a great traveller and col- there, and Fast of the $M$ ts.

lector in Zoology, having made a 1. Var. Oregonensis. Dark brown, voyage round the wordd, travelled nearly black on the back, belly whites in Peru, Panama, West Mexico, body $6 \mathrm{ft}$. long, 3 high, tail 2 or $3 \mathrm{ft}$. Sand wich Islands, and Bengal. His long. A large ferocious animal of greatest Asiatic excursion was a the mountaina. Is it not a peculiar journey from Calcutta to Assam in species? Fclix oregonensis.

tho Imalaya mts, by the Baranputra 2. Var. Very near the Pennsyivarivers it is to be wisthed that he nsay nia or rather Alleghany Couguar. publish hia Journal of it. He has Body nearly untirely tawny. or bay, brought to Philadel phia some fine or rather shorter, amaller and lower new animals and many shells. Than the last, inore slender, less fe-

Ainung his quadrupeds, he has an roceous. Dwelling in the plains otterfroin Assam, which I pronoune- east of the mountaing near woods, ed new, and he has permitted me to but pursues the game in the plains or describe. I call it lutra concolor, prairies, preying on deer, elks and being of a uniform color; it mighi buffuloes.

also be called L.amblonyx from its I find in Leraye's travels that a blunt claws.

maller animal, nearly similar in

S. G. Amblonyx, Raf. Claws, short/color, but not larger than a cat is 
coked, while otter.

ch. Entirely tail deprsse claws blunt. length $2 f$ is. and tail ench no whiskers, hall close incanine teeth feet short to toes, and tail slender

the Garrow land, seldom 8 on fish and ATINESQUz. 332.

$h$ has again ge to Buenos whence he rany rare ob$y 1832$.

s. By C.S.R. ticle on our to state that of tygers are wilds of the and West of

be noticed. at two other ve been seen Mts.

Dark brown, belly white tail 2 or $3 \mathrm{ft}$ 8 animal of to a peculiar (ais.

Pennayivay Couguar. wny or bay, and lower der, less fethe plain near woods, the plains or $r$, elks and avels that a similar in han i cat is found east of the Oregon mountains, plowish color; cere and lore brownish; which is very fierce, and often kill syes black and bright, iris yellow; large animals, will sheep and gonts liead greyish above and acrous the by jumping on their necks and cut. e fes, nearly white beneath and above ting the fleah and arteries, until the evos; feathers neirly black with they fall. Is it $\mathbf{n}$ new species? a lead colored cast, white at their Felis macrura, Raf. Entirely of a base; wings slate colored beneath; sallow color, tail as long as the body, Uropygisl feathers inixt of blisk which is froin 1 to 2 feet long only' and grey. Tail wish a rusty band at the end. Feet yellow very strong, feathers not quite to the tocs. Claws 10. Oимгтносоor.-Description of strong anid black, that of the middle new Eagle from South America, toe game color as the bill.

Aquilu dicronyx or Macarran Fa- When younger this bird was en. gle. By C. S. K. $\quad$ tirely of a bluish black, or clark lead Mr. Macarran of Philadelphin has colos, the liead and tnil have since had for 3 years in his smull menare. chanured, lout the rusty band of the rie and botanic garden, a beautiful tail and claws wrre permanent and rie and botanic garden, a beautiful tail and claws w're permanent and ai:- during the coldest winters, being this eagle and the whitehearl eagie. a native of the cold climate of An- Mr. Audubon admirsel this ato tartic America. Ile was found by and wanterl to purclense him; int Nit. the mate of a vessel near Buenos Macniran woulil not take leas than Ayren, while yet young, feeding on 8100 lur hisn.

a dead horse, and taken alive with out much difficulty. He has grown by $\mathrm{Mr}$. Mer of the lills of East liatraticky. and wanting to when they annoy him, he is very I discovered in 1823 a new land tame and grateful towards lis keep. salamander in my excursion to the er: he know him as well as friendly falls of the river Cumberland, dwelvisiters, and greets them by peculiar ling in the lills near that river in postures, looks of cries. He has se- East Kentuckv, among logs and veral-kinds of cries rather hardh, to rubbish in woods.

express joy or anger. He feeds on It is a sluggish and ugly auimal, every kind of flesh, ofinls: or even but rare and not ensily detected fish and dead animals. He will kill anong dried leaves, being of a dull rats and eat them. He is a beauti-color, only 3 or 4 inches long. ful noble bird. when he expands the Salamandralurida. Entirely grey wings they flli his large cage. His with two rows of black spots on the gait is clumsy and he oftener jumps back, tai long as the body with than walks. I have called him Aquila dicronyx tuil is rountiel as in the land salafrom the singularity of claws of two manders, and the toes are 4 and 5 colors. ns in the whole genus.

Aq. dicronyx, spec.ch. Bill horny, I take this opportunity to state feet yellow, claws black, but the thit $\mathrm{my}$ sal. or sp. hucifuga of last middle claw horny or whitish; pir- No.ie different from the Salamandra mage blackish. head greyish, tail longicarida of Green, having comwhitist, end of it rusty

Description. - Total iength 3 feet, this last, that the dots are larger, wings expanded, 9 feet; bill large fewer, rounded, and lacking beitrong 4 inches long, shaped as in neath; head smaller not so fiat, the eagles, of a horny or whitish-yel- mouth smaller "with mioute acuto 9 . 
teeth in both jaws; but the eres are having 10 Scales in the middle of the titant membrane very properly com- havin

pared to that of the owls by Green. eso

12. Description of two new geners of Soft Shell Turtles of North America. By C. $\mathbf{S}$. Mafinesque.

APALONE and MESODÉCA.

The following account wss prepared for the Plilosopical Society of N. York in October 1816; but not published at the time. It is now given as written 16 years ago.

The Zoologists had preserved the Genus Teatudo of Linneus, till Dumeril in 1806 established the G. Chelonias for the Ses turtles with feet like fins, the $G$.
Chelys for the 'T. matamula, and the $G$. Chelys for the 'T: matamula, and the $\mathbf{G}$. Emys for all the turtles with 5 moveable palmated toes. Lately the G. Trionyx has been proposed by Geoffory for the between the falls of Hadley, Glen and sort shell turtles with 3 toes and claws. Baker, and further up to the source. It But last year I proposed in my analysis is called mud turtle and not eaten. It is of Nature (Palermo 18I5) to divide the a lively pretty animal,', quite barmless, as Turtles into 15. G. as they offer so inany ther important Characters.

They were 1 Chelonias 10,2 Teatulo $D$. 3. Gophemse, Raf. With flat round nails. Type. T. polyphemu" of North Americs. 4. Chelonuro, Raf. with long tails 5 \& 4 many Sp. here blended.
mass

5. Chelymo baf with sulcated back. Type T. coriacca.

Trionyx of $G$. 7. Cheliphus, Raf. Water turtles with Valve eet.

S. Uronyx, Raf. an snterior valve to the shell, toes and claws 5 and 4 , tail with clay. T. Scorpioides, \&a.

9. Didicla. Raf. Bivalve lower shell toes 5 and 4. Type T.clnusa, odorata, \&C. 10. Monoclida, Raf. Lower shell valvu

Iir anteriorly, toes $5 \& 4$. T. retziana \& c 11. Emyda, Raf. or Emys D.

12. Chelyda, Raf, or Chelys D.

13. Chemelys, Laf. Warty Scales, no valves

14. Chelopriss Rai, No valve, toes not palmated 4 and 5. T. Punctata \&eo

15. Cheliurus, Raf. No valves, feet pal mated a long scaly tail. T. Serpentina \& $\mathrm{C}$.

This year 1 have discovered in my journey to the $f$.. of the Hudson and to Lake Chsmplai... new Soft Shell turtle which has 5 toes instead of three a Trionyx, and which 1 propose to call Apalone. Bartram leas long a go descritied apalone. Bartram has iong ago descrit ed with 5 claws. which hss been common- middle, and 10 pair of bard lateral ribs,

The name is contracted from Apaloche lone meaning Soft turtle.

Char. G. Body and limbs soft without cales. Nose proboscidal, jaws without bill. Upper Shell smooth soft with a all keel anteriorly. Lower Shell ante , body denudsted behind. Fire pal ated toes to all the feet, with small
Tail short corrugated. Apalone Hudsonica, Raf. Upper shel rical, flat, entire, yellowish whown spots, and a circular black the near the margin. Two oblong occuated spots before and bebind the eyea. alluse micronste shorter ell. It dwells in the mud no horny hand surie. itself under it in winter. It feeds on small shells and fishes.

Body olivaceous striped and dotted with brown; but entirely and dotted out wart gated when extended, gated when extended, grayish clouded small with 2 a fore fore and one behind each eye, oblong yellow with a black msrgin, appearing fike as many eyes; while the true eyes between them are small round with a yol tubular like a proboscia extending beyond the mouth, and truncated with 2 round nostrils. Mouth large, with thin soft lips. The hind purt of the body is denudated beneatb, the lower shell extending only half way from be. fore and is blueish white. Vent round, tail conical short thick rugose obtuse mucronate. Feet spotted, toea black, 5 unequal with small clswi. The upper the margin is yellowish unspotted, then comes a circular black line blackish but potted of brown, while the centre is aliraceous yellow with many round pots occulated and clouded by having brown margin aith grey dots within. Tre he small half keel extenda only to the II. N. G. Mesonec Raf.

The name means midelle witb ten Scales.

The name mesns midalle witb ten Scales. G. Ch. Body and limbs soft upper 


\section{5.}

ferox, this must pus Mesodeca by middle of the

ed from Apalochembs soft without l, jaws without ooth aft with a ower Shell antehind. Fire pal. feet, with smal gated. af. Upper shell a circular black wo oblong ock pebind the eyes. shorter than the ecies from 2 to 6 Niver Hudson , Gien and the source. It th is ite harmlesa, as orny hard jaws. sand, and buries - It feeds on

ed and dotted smooth with. tible and elon.

rrajish clouded

be feet. Head

c apois one be.

h eye, oblons

gin, appenring

the true eyes

round with

ike a proboscis

uth, and trun-

- Mouth laree,

ind Mouth large,

ind part of the

way from be

Vent round,

ugoase obtuse

toea black, 5

The upper

ttily apotted,

potted, then

blackiah but

the centre is

nany round

ed by havine

dots within. shell below.

th ten Scales.

soft upper

acales in the

lateral vibs. with many horny warts before and be- Boston to Lake Erie. It neglects hind. Lower shell hard and horny in the fossils also, and lacks the solil founmiddle. Head with lateral comparti. dation of Oryctology. It surmises ments above and laters contractible that all the rocks of the $U$. States warts. Nose proboscidal. Mouth witl) must agree with those of the North, horny jaws. Five palmated toes to sil must agree with those of the North,
without being able to prove it, since Mesodeca bartrami, Raf. Upper ahell Faton who has laid out the series of elliptical entire brown unspotted. Head long, neck rugose, warty. Symonyms. Great Soft shell Tortoisc South Bartram's travels in Florida (Philadel- Plutonic theory.

phla 1791) page 177 to 179 fig. 4 and 5. 3d. The English school believes Testudo ferox of many authors but se- that the whole world is to be found veral species have been blended by in England, and that our strata and them, found in Carolina, Alabams, and formations must agree of course with Louisiana, while Bartram says he foind those of England. Prof. Featherthis only in East Florida. The T. ferox those authors; but their figures and descrip. this System of Geology, and now tions must be compared sud revised. publishes a Journal of Geology is When not copied from Bartram they ap. very sanguine and active on that ply to other species or the true ' $T$. ferox opinion. He has many followers, of L. frat figured in Thilol. Trans. vol. 6. who all incline to the Huttoninn ig. 10. See also Lncepedc, rol. This turtle of Bartram cannot more be gy is as needful to Geology, as Chrothe T. ferox which is a true Triony $x$, than nology is to History; but have hardly the Apalone! For the complete descrip-| tion and history of this species see Barthen are sites. the most explicit descriptions of his book, $4 \mathrm{th}$. The fourth school is my own, and the 2 figures of the body and head I call it the Nalural and Oryclolsare no doubt correct. It is a large sp. gical Method of American Geology. 21 feet long and weighing from 30 to 40 rical ib. excellent to eat Although carnivo. rous it is no more ferocious than all the tures in Lexington in 1819 and 1820. other turtles and terrapius feeding on Mr. Cliffurd and others had adopted. it. I have not published much upon: New.York, October, 1816. the ideas of the systematic writers. the ideas of the systematic writers.
But after 30 years of observations 13. Geology and Oryctology. But after 30 years of observations Extracts of a Series of Geological Letter's boldly venture to compete with then to Prof. Ac. Baosoniant, President of for what I have seen and studied, the Geological Society of Paris; by Prof.
C. S. Rurixngave. C. S. Rupixrouve.
while they have not. My thenry is
not a system; but the result of what First Letter, March 1832. not a system; but the result of what

There are now 4 schools or Sys- Thave seen in the South tems of Geology in the U. States. Sicily, the Azores and this Conti1. The old school to which Maclure, went: nor do I mean to apply it to Mitchell, James, Troost, Nuttal, the whole world, as I deem that Schoolcraft, \&c. belong. This is every t'egion has peculiar local feaproperly an American branch of the tures. I take besides whatever is properly an American branch of the tures. 1 take besides whatever

fossil remains and merc!y depend I propose to divide the formations upon the position of rocks. as follow, in 3 series and 10 groups; 2. The Northern school of which each with many formations. 2. The Northern school of which
1. Series.-Inorganic formations. founders: it has many followers in $1 \mathrm{gr}$. Uniform formations. the Northern States. It is based $3 \mathrm{gr}$. Volcanic formations, including upon the series of formatious from . the Basaltic and Trupic. 


\section{6}

II. Seriea.-Organic formations. $4 \mathrm{gr}$. Primary or Vetusial. $5 \mathrm{gr}$. Secondary or Planial. $6 \mathrm{gr}$. Tertiary or Alluvial.

My primary organic formation an swers to the transition of Werner the secondary to his floetz rocks and the tertiary to the deposited al luvions, diluvions, \&c. which I divide into diluvial, fluvial, pluvial and litoràl.

lí. Series.-Anomalous formations.

$7 \mathbf{g r}$. Vegetable formations.

$8 \mathrm{gr}$. Animal formalions.

9 gr. Human formations.

$10 \mathrm{gr}$. Atmospherio formations.

I am prepared to support and de monstrate this natural theory, by physical, oryctological and ocular proofs. I have taken, as it were nature sur le fait in Sicily and America. I have seen the various anomalous formations forming. I have discovered the craters or mouths of noes, calcareous, slaty and carbonic, to which are due all the organic furmations. When not visible, they are covered or obliterated like those of basalt and inany volcanic strata.

an this series. I deem all these organic strata of the second series,

formed by emanations or salsic eruptions of oceanic SALSES or subinarine pseudo-volcanoes, except the are above and below them. There modern alluvions; but many ancient is no need to suppose a miltitude of alluvions may also be owing to wa-physical revolutions, successive tery salses or eruptions of water. floods and cataclysms to form them Baron Humboldt has surmised that out of vegetable ruins. All is easily the Aviatic flood was caused by an explained by alternate emanations eruption of the Caspinn sea. Our or eruptions, with the other organic American lakes may have caused formations. Has it ever been calca. floods with us, and Volney deemed lated what would have been required Lake Ontario such an aquatic vol- to form our carbonic strata out of cano. ignose fragments; forests cov-

These volcanos were not ignivo- ering the whole 'earth, (which was mous like those of the first period or not then quite dry land, with trees series, but salsivomous; they were as thick as the grass of $\dot{a}$ meadow, under the sea in the primary and se- would hardly be sufficient for a sincondary formations; but on dry land gle stratum. And we have many in the tertiary. They ejected by turns such over eacli other, separated by and alternate paroxysms the mud thick strata of sclist, grit and lime. or alimes which liave formed the or- The regetable fossils found in them ganic strata; either calcareous, slaty, most of which are marine, have been argilaceous, carbonic, gritty, sandy, limbedded there, as they have in the 


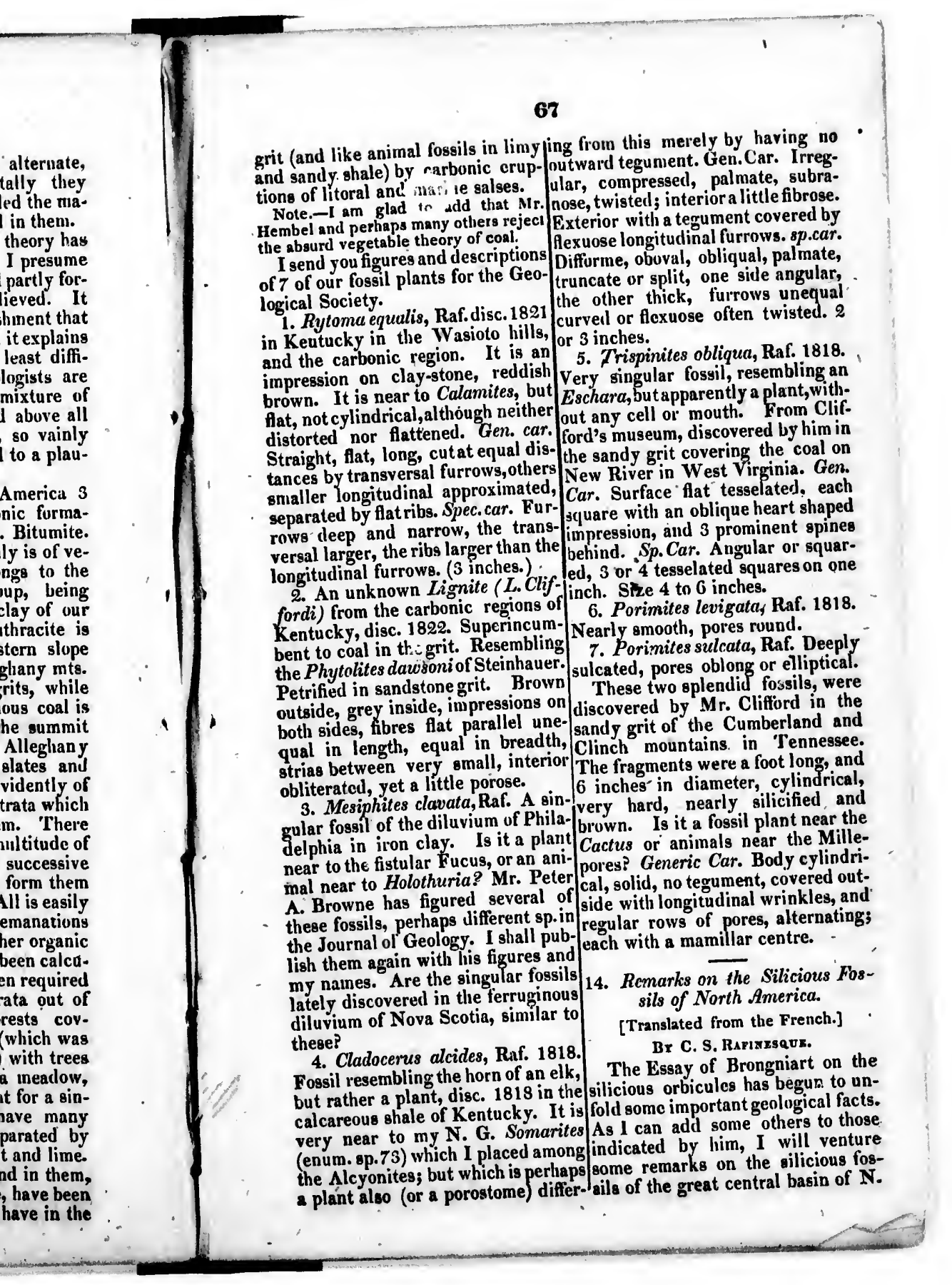


America. This immense basin ex-1 It appears that the geologists do tends from Canada to the Gulf of not yet know well this fine region Mexico, and from the Alleghany to of fossils whose oryctology was tirst the Ozark mountains which are grit-exploreel by Clifford in 1814 to 1820 , ty mountains, while the basin itself and next by myself in 1818 to 1826 . is of very ancient limestone, altho $0^{\circ}$ Maclure has designated all the requite horizontal, but often covered gion west of the Alleghanies as se-

with hills of slate, coal and sand-condary, and James calls the same stone.

Prof. Brongniart has mentioned transition. Brongniart appears un-
decidel whether it is transition. In some of the fossils which I sent him fact it is neither strictly the one nur in 1820 from this region, (T'ercbra- the other! America is not always tula, Shophomenes, Favosites) which similar to Europe in all the formahad on them silicious orbicules. I tions and strata. It has neither could add many more as I have seen chalk nor lias? The Oolites and several others on Turbinolites, $\mathrm{Or}$ - clays are often out of place! The thoceratites, \&c. My Cyclorites tur- ancient or pelagic limestone of this binolia covers all over one of the region as well as the slates and grits first. I consider it like all my cy- which surmount them are of transiclorites of the S. G. cyclepite as tion by their appearance and ancient parasite animals become fossils along tribes of fossils; but they are similar with their support. Among my $G$. to the secondary of Europe, by the Cyclorites published 1819, and a horizontal position of the strata, and complete monography in 1831, the silicified fossils like those of the there are some flat and fixed, oth. chalk. They form therefore a kind ers fixed branched, free and simple of peculiar series, deserving perhaps with 1, 2 or several orders of circles. a prculiar name, since the English While in my G.Fibrillites, the whole appellation of mountain limestone is striated in the interior as in or carboniferous limestone do not the Tethya of Donati and my G. properly apply; they do not form Bolactites.
mountains, but inferior horizontal

Yet I do not doubt of the globu- strata, and do but seldom bear the lar and circular cristalization of the coal. I have called it compact when silex. Far from it, I have always it is nearly homogeneous and specubelieved in it for 30 years past, even lar when it has a shining lamular when hardly any mineralogist could fracture, \&c. The fossils are disbelieve it. Besides the mamillar seminated in it very unequally, being and oculated calcedonies and agats, sometimes very rare, but accumulaI have seen jasper, onyx, cornelian, ted in some localities. Some, species quartz, and chert, \&c. with cristals are very abundant and others very either mamillary or hemispherical or rare. Their great antiquity is proved lenticular. I have' several speci-by the ancient tribes to which they mens in my cabinet, such as red chiefly belong, Madrepores, Millejasper, blue and white onyx, \&ic. 1 peres, Turbinolites, Favosites, Teshould therefore be inclined to be- rebratulites, Encrinites, Alcyonites, lieve that some of the orbicules men- \&c. with some Trilobites and Cephationed or figured by Brongniart are lopodes.

orbicular cristals; but there are But the most striking fact consome, which with my cyclorites, fi-sists in the complete silicification of brillites and others omitted, have all these fossils of nearly 1000 difthe appearance of being animal fos-ferent species. Most of them are sils of ancient pelagic alcyunites, casts of destroyed animals replaced become silicious, like nearly all the by a silicious matter. This is confossils of the ancient limestone of stant in the limestone, except in the Kentucky, Ohio, Tennessee, \&c. lucwest and uppermost, the shaly 
ologists do fine region yy was tirst 314 to 1820 , 18 to 1826 .

all the re-

nies as se-

8 the same spears unnsition. In the one nor not al ways the formaas neither olites and ace! The one of this es and grits of transind ancient are similar pe, by the trata, and lose of the ore a kind gg perhaps e English limestone ie do not not form horizontal

bear the pact when nd specu-

- lamular

are dis-

aly, being

ccumula-

e species

lers, very

is proved

iich they

s, Mille-

ites, Te-

:yonites,

ct con-

ation of

300 dif-

iem are

eplaced

the

shaly

limestone, which covers the oldest globulites, mamillites, lentilites, \&c. in some places, or elsewhere is un- and the organic fossils; such as the der the sandstone or slates. The fibrillites, cyclorytes, bolactites, grasame happens in the long but narrow/nulites, \&c. which may resemble formation of limestone called transi- them, and also the geodes from the tion, which borders on the mts. Al-gendites. If the silicions orbicules, leghany to the East dividing them \&c. were always minerals, they from the primitive hills. 'The 'Tri- should not be so rare, but common lobites and 'Terebratulites, \&c. are as the cristals inside of silicified there also silicified. While in the shells. Out of thousands of silicious limestones of New-York $\mathbf{N}$. of the fossils which I have examined, I have Alleghany, or superposell to the E. only found cyclorites upon a small of them, the fossils are nearly all number. I have hardly ever seen calcareous. And in the vast marl any spiral epizoites and very seldom region from Long Island to Florida nodulose orbicules. But I have seen along the sea, all the fossils are cal- some radiated, and others with small careous or unarly. A few later fos- circles within larger ones. The vasils of Kentucky, \&c. not silicified, riety is great. If the free cyclorites are chiefly found in inarly forma- werc only orbicules they should not tions. be so rare. Some are totally chang-

The fossils of this central region ed in calcedony, they should then can therefore. be known at first sight be deemed circular calcedonies; but when seen silicified in limestone. they are very different from the ma. Thus the cyclorytes and silicified millar, and occulated calcedonies. alcyonites may well be animals like--Yet I was right to say that the fossil wise. This becomes very clear when alcyonites form as it were, a link many of them are seen, which ap-between animals and minerals, as proximate to living animals of the they approximate in shapes; but my Tropical seas and Mediterranean. fibrillites (decidedly organised an-

As a striking instance $I$ add the mals) proves the animality of many descriptions (and figures in the ori- others gradually linked by the ginal) of 2 N. G. of mine from the forms. C.S.R. sea of Sicily.

1. Psadiroma rubra, Raf. Analyse Nots.-The tendency to silification of Nat. 1815. Family of Polactomes-all animsl substances is so very great in Animal fixt upon shells, fleshy red, the weatern strala, that even parts of smooth, elliptic, flattened, inargin bones and horns of quadrupeds bave been irrot found partly silicified outsicle, I have in irregular, many flexuose concentric my calinet a remarkable instance of it in sirias, centre with an expansible the fossil horn of my Mazama salinaria. mouth without tentacula. which is intact inside, but purtly siliciona

2. Peritrema lobularis, Raf. disc. outside: although this fragtment was in a 1807. Family of Alcyons. - Fixed on late furmation, not in a stritum and belongs to the latest age of foseil animals. rocks, lobed, compressed, fleshy, brownish, with many lings on the 15 . Demanke on the surface, having a hole or pore in the centre. Every hollow mineral with cristals These two animals appear to re- inside lias often been cylled Geode. Papresent the ancient cyclorytes of the of the Dict. of Nat. Hist. hso very well pelagic world; but many more exist diatinguished the volcanic Gendes from yet in the seas. It will therefore be needful to clis- deemell fossil nuimals. tinguish with care among the silic - Our ancient limestune agrees also with ous fossils with simple forms, those the chalk by having similar geodesi which are really inoroanic, such as of Geudeg in our ancientlimeatone some the orbicuięs, spirozoites, annulites, like those of the Niagara lime atone, 
which Eaton has called Geodic limestone, 9. G. Divisa. Oblong, with a partition contain oreat many cavities similar to in the cavity inside.

the volcanic Geodes and filled with cris- in $10 \mathrm{G}$ Biloba. Oblong, bilobe, with two tals, while in Olio, Kentucky \&e, and rounded parts nearly equal.

chiefly in the Wagioto or knoblills, the 11 . G. Lobata. With many unequal ircherty limcstone and even the andatone regular lobes.

cherty limestone and even the asudatone fectly gilicified like the other fossils, filled inoille with fine cristals of quartz. These geodes which I have called geodites in my enumeration, appear to me to be fossil animals, like those of the are always thick. often smooth, without cyclorites or orbiculites. Some are very large, I could have collected many, but they were too heavy to carry. They are often fuund abundantly in the ravines,

glens, and torrents of the hills, mixed

with rolled stones. I have seen soine cal.

cedonised. It is somctimes needful to break them to ascertain their geodic nature, as the outward appearance is delu. sive.

2. G. Elongata. Long ohlong, nearly lindrical, amooth.

13. G. Cavernosa, Irregular with seve. ] cavitiea.

14. G. Amorpha. Amosphoug, unsbape. a single cavity.

15. G. Dispar. Oblong, with \& large ink on one side.

16. G. Turbinata. Nearly turbinate, rough, one end attenuate, the other con. vex depressed, cavity small. Very gingucr ap fulvous uneven outside, ingide changed in white quartz, cavity within with mainillar crystals.

16. On the Carulites and Antrosites. My N.G. Cavulites followa the geadites in my cnumeration. It differs clicefly by But if they were snimals, as they have having outwsed cavities or openings to no visible mouths, they must have been the internal cavities. The cavulites which porostomes become fossils. See my letter contain na many sp. as the geodites, sre to Cuvier upon tlie porostomes. Inot therefore porostomes, but may be true They will al ways be easily distinguish-palcyonites or apongites having mouths or ed from the chert and silicious fragments openings to the internal atomach or ca. of jasper, quartz, \&c. imbedded in the vity.

cheriy limeatone by not being in any way Another N. G. of mine, which I call angulac, nor ringed.

- Many kinds or species can be jistin. guished smong tliem, but they often run into esch other by gradual forma or colurs. The G. Ievigata of my enumera. tiun, op.74, would probablyinclude many auch. The colors are variable, but chiet. ly uniform in eacli apecimen, the whitish, yellow and rutous are most common, but variniss shades of red and brown are also found. 'The sizes vary from that of an orange to the size of 1 to 25 pounds.

from 1 to 25 pounds. Antreaites, forms the link between them. lias no outward cavities, but a single arge opening or hole communicating with the internal cavity. A living sea $\mathbf{G}$. of Sicily called by me Megastoma in 1814 comea very near to this, but bere the pening is still larcer and the body is fixed not free. This Megantomo ever a rery singular animal. It is called cedme di mari or sea citron in Sicily, combling outsice a larre citron rough comewhat mamillar ineide quile amootb. substance thick cartilaginou Pised substance thick cartlaginous. Fixed on cur it appears $t 0$ a The fullowing kinds offer the most atriking forms.

1. Geodites leviguta, Raf. Commonly a litele elliptical, not compressed, nearly

2. fi. Compressa. Elliptical, compressed one side amuother than the other.

3. G. Snlcnta. A little elliptical, wit some furrows or wrinkles unequal an irregular.

4. G. Globoen. Globular, smaller than the otherm a little rough.

5. (f. Phaiops. Oblong, nearly smoot dark brown.

6. G. Ovoiden. Ovoidal amooth, one eoi omaller.

7. G. Mamila. Elliptical, somewhe memillar oulside. 8. G. Eryelvea. Red, oblong, amooth. nicating. Thu covulites and antrogites have many pecies, of as many colors as thie geod. tes; but their size is always smaller, and hey are more rare, some ap. very much . I aliall give here a few of themi but gures ahould be required to make them mall knowni they will be figured here. after.

1. C. ambloides. Subglnbose, outward avities amall and unequal, fow invide and mall.

2. C. anastoma. Oblong, cavities almost anastomosed, large cavities inaide. 3. C. geadica. Ovoidsl, large cavities outside, only one invide, hardly commu. 
with a partition bilobe, with two billobe, with twc

8 ohlong, nearly egular with seve. rphous, unsbape. g. with a large Tearly turbinate, e, the other conoutside, inside ta, cavity within

and Antrosites. ows the gendites or or openings to carulites which he geodites, are but may be true. aving mouths or stomach or ca.

e, which I call between them. ies, but a single communicating A living sen G. gantoma in 1814 , but here the nd the body is sastoma in how nal. It is called n in Sicily, recitron rough equite rough or quite smooth, ous. Fixed on ive, since wher sites have many ites have many rs as the geod. smaller, and ap. very much w of thema but do make them figured here. ea. abose, outward , few inside and of, cavitiea al. eavities inside. large cavitied hardly commu.

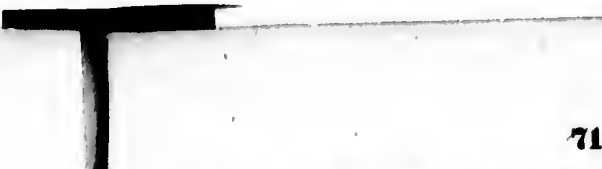

4. c. unica. Flliptical, a single cavity tologigts. He has already issued in inside, few outside unequal, one united April a first series of 8 casts and Apred with a gynop5. C. vermicularis. Unshupely, with tical table, among which a N.G. di5. C. vermiar cavities outside and inaide. tical table, among which a N. vermicular cavities outside and inaide.
6. C. amorpha. Unahapely, cavities pleura and 4 new species of G.asa6. C. amorpha. Unahapely, cavitiea phus and calymene. He has omitted 7.C. equalis. Subglobose, cavitiea near7.C. equalis Subglobo ly equal, few inside.
8. C. depressa. Elliptical compressed, cavities unequal, only one or two inside.

2. G. Antrosites.
I was among the first to attend to
andies unequal, only one or two inside. 1. A. globosa. Globular, surface nearly the trilobites in N. America. In 1817 anooth, small opening, large cavity. Dr. Schaffer presented the first spe2 A. elliptica. Elliptical, surface a lit. cimen froin the Catskill $\mathrm{mts}$. to the tle rough, opening at one end, large ca- Lyceum of New-York, as a fossil vity. A. camerata. Kllipsoidal, aurface quite unknown. I pronounced it a
3. ncarly smooth, opening lateral, csvity di. new genus of lossi entomostraces 4. A. defressa, Eilipsoidsl, depressed, cephala in a paper l'ead before the nearly smooth, opening very small termi. Lyceum; being very near to the $G$. clomeris of I atreille or amnadillo of 5. A. nodosa. Rounded surface, knob. glomerlo by or mamillar, opening small, cavity ir- Cuvier. Soon after I found in the work of 6. A. magna. Amorphnus rough, un. Parkinson, that he had been the first 6. A. magna. Amorphnus rough, un larke even, opening large, cavity by two united nome of Trilobites, a verý good and lobes rounded, nearly smooth, openin irregular.

8. A. rimosa. Owidal with many chinke opening and cavity large.

Brongniart in hublished in 182\%, (n) olaims to have read be9. A. incurva. 10. A. direma. Oblong nearly smooth, two unequal openings, one at each end, jus guse the name of trilobites cavity large. This last uught perhaps to just cause the have left to the 列 openinga, and be called Ditremites levis. group calymene: restored, because there is a pievious ly silicious like the geodites. The antro- G. calymenia of Ruiz and Pavon in ly silicious like the geodices inse, but the cavvlites very seldum. They are from botany. the same locality and chicfly from East has taken place on the subject of these animals, some deeming them

17. On the Gencra of fosail Trmoirrss or shells near to cliton; but the preGromentres of North America. Br C. sence of eyes 8. Rammzavi. Philadelphia, May, 1832. feet being smill and soft, have been

Prof. Green of Philadelphia, is obliterated in the fussilization. engaged in the investigation of all In 1821, I sent to curope the dethe Trilobites of the U. States; alscription of 12 Amrrican trilobites, labor very much wanted; as these and I published in Kentucky the N. labor

interesting fossila are very numer- GIso ctomesa. ous with us, and but few as yet pro- In 1824 Dr. Kay produced it again perly named and described. Itistead under the name of isoteles and in

Dolman has described inany Eu. in plaster of all those he can procure. 'This improvement is novel here and ropean in North America, offering 10 
many striking generic distinctions 5.G. Dipugura,Green, 1832. Not As far as I know them they must|trilobate, subglomerate, 2 .oblique form at least 15 genera, and 4 series eyes, thorax with 14 segments, abof beings, with many, two, one or no domen or tail orbicular. See Green's eyes.

I. Series or Section. More than series No. 3.

two eyes. Polxopsirivs.

6. G. Asaphus, Br. 1822. Trilo. bate, not glomerate. Abdomen or

1. G. Alcoorops, Raf. 1821 . Tri- tail expanded large, without seglobate not glomerate, head with 8 ments. Thorax with many segunequal eyes in 2 longitudinal roivs. ments. Many sp. see Brongniart 'Thorax and abdomen with many seg- and Green.

iments. 1. A. fexuola, Raf. about 20 flexuose segments, fore eyes smuller, tail a little jutting obtusc. Cabinet of 'Transyl. University, from ol limestone of $\mathbf{K}$ entucky.

7.G.TRILonit kg. Park.1812. Glo merites, Raf. 1817. Calymene. Br. 1829, and Green, 1832. If the name trilobites is not to be generic, calymene must be changed nevertheless

2. G. Diplo psires, Raf. 1821. for diopsites or geoplaxis, Raf. many Not trilobate nor glomerate, head sp. I descr. 2 in my enum. T. eurywith 4 eyes double on each side. cephala and T. granulata. Green 'Thorax and abilomen with many seg- has 5 sp. in I. series, of which 3 new; ments, 1.D.levis. Very smooth, eyes but his pretty C. calicephala ought to equal. An imperfect specimen in the form a sub-genus Orimops, Raf. by Cincinnati Museum trom Ohio.

eyes annulsr or with a central dot

3. G. Tomongus, Raf. 1821. Nat and head with a curious relief like a trilobate but glomerate, hesd very flower de luce. The $G$. differs broad, 2 large eyes , cut in two chiefly from asaphus by having the lengthways. Thorax with few seg-abdomen with segments or blended ments, 4 or 5 , abdomen large entire, with thorax, and both glomerate. Type. 1. T. mimulus, 1821, (or my 8. G.Texesrops, Raf.1832. Difiers trilobites simia, enum.1831.) Smooth from the last, by head very broad, \& furrows before each eye. Cabinet with remote lateral eyes, very large, of Clifford, found in Salt River prominent and reticulated. 1.Type. Knobs.

r.leiocephas, Raf. Head smooth,eyes

II. Series or Sections. With two reticulated by dots, flat and smooth eyes.-Diopsitus, Raf.

above, thorax with 11 segments, la-

4. G. Is0 ribs duplicate, abdomen or tail teles, De Kay, 1824. Nileus, Dolman, with 7 segments flattenุed not dupli1826. Not trilobate nor glomerate. cate. My cabinet, from Virginia, seHead and abdomen large entire, 2 veral sp. blended under C. macrophdistant eyes. Thorsx with 8 equal thalma of $\mathrm{Br}$. must be united here, segments. Type 1. T. emarginata. and probably also my T. eurycephala Eyes round, abdomen larger than or Telesiops granulata. The $T$. the head, retuse or notched behind. leiocephas I have ceded to Prof. Cabinet of Trans. Iniversity, pre-Green.

sented by Judge Bledsoe, found near - 9. G. Promenites, Raf: 1832. BiHarrod's Lick and Paris in Ken-lobites, Raf. 1821 and 1831, in enum. tucky; in old limestone. The lacrest I have changed the name as there trilobite known, being 9 inches long are several G. bilobites. 1. Pr. lunula and 4 broad. Difierent from the I Raf. 2. Pr. bilobata, \&c.

gigas of De Kay, which has bilobed 10. G. Ooxars, Brongniart.

eyes and is not notched. I. plana.D. III. Section or Series. Only one and other sp. belong to this genus eye? Monopsirss, Raf.

also. The G. Denus of Dolman, 11. G. Metapteles, Green; or 1...dly differs having only 9 or 10 M onopsitss, Gr. or Cerytozites, segments to thorax, it may form a Gr. All these namea proposed by sub-genus. 
en, 1832. Not te, 2 oblique segments, ab- See Green's

1822. TriloAbdomen or without segmany seg. ee Brongniart

rk. 1812. GloCalymene. Br. If the name generic, calyd nevertheless xis, Raf. many num. T. euryulata. Green which 3 new ephala ought to imops, Raf. by a central dot, pus relief like a the G. differs by having the nts or blended glomerate.

a..1832. Differs

id very broad, res, very large, lated. 1.Type. id smooth, eyes lat and smooth segments, labdomen or tail ned not duplin Virginia, ser C. macrophe united here, r. eurycephala ta. The $T$ led to Prof.

Raf: 1832. Bi-

831 , in enum.

ame as there 1. Pr. lunula . gniart. . Only one - Green; or RYPTOLITIS, proposed by
Green; he shall select probably the They are found all over the world, best. Singular $\mathbf{G}$. without eyes? but but those of $A$ sis, $\Lambda$ frica and l'olyneaia are with a big central knob like an eye little known as yet. Those of Europe only the head known trilobate, with have only been observed within 50 years only the head korth America by myself a fine reticulated forehead. $2 \mathrm{sp}$. see within 16 years.

Green's work.

IV. Section or Series. No eyes. 1. Those of Italy, in Modens, the A Nopsites, Ra

12. Aonostes, Br. 1822, Batus 2. Those of Siclly, .Macaluba visited 12. Aanostes, Br. 1822. Batus, by Dolomieu and mynelf is the most fo
D. 1826. 13. Paradoxides, Br. 1822. Ole- mous, as having sometimes firy efurpthese alce 14. A pyx, Dolman, 1826. Tho. clay, sulphur, magnesian miarl, \&c.

14. Ampyx, Dolman, 1826. Tho. clay, sulphur, magnesian niarl, \&c. rax with few segments, abdomen or 3. Those of Crimea, described by Pallas.
tail expanded.

15. Retusites, Raf. 1821. Head and salt. retuse or bilobe, body trilobate with apouting apringa, producing many earths many segnients, abd. not expanded. and even silex.

1. Type. R.levis: Head short sub- 6. 'Those of Murcia in, spain, near Oribilobe, about 20 semnents, midlle huela. Quite 'ately sprung in 1829, witl dreadful eartliquakes, but no fire. A It will be nictit wus desolated It will be noticed that I have call- and aH the villages destroyed. The ed head, thorax and abdomen, what ground was filled with clefts and millions others call clypeus, abdomen and of small craters, throwing out and, black tail: my view with the lin shells! and sea weeds! (see the Desct. in with the living genera, and whatever Bulletin of Geograpliy of Paria.) Thia bear eyes must be $a$ head. $\quad$ great eruptinn of our times is a complete proof of the volesnic formation of many

18. On the Salses of Spallanzani gave the name of salses to or strata with organised fossils.
the mud volcannes of Italy, which com.
Two other recent inatances of volcanic monly throw out salt water at the game eruptions of mud and eartlis, will be given monly throw out aslt water at the same eruptions of mud and plied as a generic name to all the volca- In 1322 . Tlie mountsin Galungun, near noes which throw mud, slime, clay, marl, Clieribon, in Java, had a dreadrull erup: lime, asnd, \&c. inatead of lava, stones, tion with explusions, eartliquakes and gravel, pumice, cinders, obsidian, \&c. lightnings; but no fire, no flume and no Water, air, gases, fumes, sulphur, iren lava. It rained ashes and hot mud, with and many other substances, are common earth and stones, which formed s stratum to all the volcanoes, of which there are 70 feet deep, 20 miles long and 10 wide, at least 4 series. Earthquakes, heat and overwhelming 114 villages, and deatroyfire, are more or less commonto all in some ing 4000 men.

of their paroxysms. And all the volcanoes In 1831 and 1832, some of the volca. exist within two peculiar fluida, air or noes East of the Andes must bave had water. The Aerial volcanoes or salses earthy or muddy -eruptions, since the are those acting in the atmosphere, the esrth, dust, and mud, was carried esster. aquatic volcanoes those existing under ly 1000 miles to Buenos Ayres, in black clouds, by the winds, as was atated in the The 4 series of yolcanoes sre, 1. 'Irachytic or lavic volcanoes: such formed in the clouds.

as Etna, Vesuvius, both aquatic and These salaic and muddy volcanoes in aerial.

2. Basaltic volcanoes, ejecting basal ta dical or remote emutions when they and traps commonly aquatic. are small, they pass unnoticed, as many 3. Carbonic volcenoes, ejecting coal have which exist in England, France and and alates; alwaysaquatic. Germany; being mistaken for curious 4. Salsic volcanoes or salses. These springs or casual phenomena. But these are both aquatic and actial. Many are small local eflects and formations are exyet existing; but they were much more actly what geology seeks as remains of mulnerous in ancient times, when the sea|former more powerful agents. covered most of the land. 
I have sought fur them in Nortli Ame. pear Glen's falls in the old limestone of rica and had no ilifficulity to find them. that region somewliat similar to the They exist every where in the seconda. Iransition of the long valley but of a $r y$ and tertiary regions. Nuny belong to durker hue; nearly black with bluiah remote aquatic furimations and eruptions cark

but several exist in actual activity as acrial salaes, witl, craters, tlirowing many earthy and saline substances.

Out of 100 interesting localities of this kind, which I liave visited, I shall here kinti, which i lian

1. SALSES of New.York, at Saratogra 1. SALSLs or New-York, at Saratc

ine, Syracuac, Mmitezum

2. Those of the great linie valley extending from New. York to Virginia east of the Alleyhany.

3. 'Those of the 'Alleghany mts, Cats. kili, \&c. with very ancient craters that threw sand or pamite formations, some timea becorne lakea.

4. Thuse of Cumberiand and Wasioto mta. of Virginia, Keltucky and Tennes see. The hollow mountain is a singular paramite crater in it very ancient.

5. I'lose of the Ohio basin, in Olio, Kentucky, Tennessee, Illinois, Indiana. Very numerous and various, of dillerent ages and perioda, called licks, sulines, aprings, \&cc. Such arc Bignob licks, Halman licks; mud licks, yellow springs, \&c. which will be described in $\mathrm{my}$ account of the licka.

6 . Those on the Mississippi, or west of 6. Those on the Mississippi, or west o it, are very numentalso. 12, they liad dreadful eruptions forming Jakes and

Murcia.

All these throw out as yet periodically, eartis and salts, gases, muil, clay, iron, lime, marl, bitumen, and, \&c. and cols tinue to inerease some amaller or local formations of those substances.

The account of these asalsic rolcanoes will be continued in other papers; and the earbonic voleanoea of North America will be described in my memoir the coal mines of North America.

C. S. Rupreseave

$$
-20
$$

19. On the LAxe Foesils.-Br C. S. Ratingsque.

Among aeveral fine fussils uf the cabi net of Prof, Green, which $I$ have aude to mine by exchanges, I liave fuund 2 ap. of a N. G. of POROS'OMrS, or ant mala without mouths, in a fossil state. was right to announce that the fossil po-
rostomitea would soon incresse in number

I have called this N.G. Lamellites uwing to its internal lamellar structure, whereby it is related to my bolactites, fibrillites and the liviog tethya. It differs chiefly from this last by its solid centre anc without cuticle. In summer the springs are species are from the State of New-Yur'k, often dry, but the saline particles

They are not silicifiel, but petrified, itto the hard limestone, and can be seratelied by irnn.

(i. Jomuelites. Indy free without a cuantsisle, lamellar in a radiating form ache circumference, centre solid i.

1 ap. I.. bilobata, Raf. Oblong, nearly bilobe, or middle contracted, encls round. ei!. Surface a little unerel1, lamellas, elongated, snlid centre small. Fine large heavy and hard fossil, 4 inches long. blackish, witli some roughness and pita itsicle, some white spois inside.

2. sp. L. dipresoa, Iluf. Discoildal, de. ressed, ncarly amooth outside, lamellas short, solid eentre large. Smaller, dia. meter over one inch, softer and of a paler bluish cast.

The figurea of these and 500 other fos.

ils will be given in my Iconographical lluatrstions.

PHYSICAT, GEOGRAPIIY

20. Iicks and Sucks of Kentucky. Br C. S. HAvinesqui.

The enumeration of these places properly belongs to Physical Geography, their ultimate history to Geology.

Their gsological name is SALSE.

They are found all over the Western

States, and even in Western Virginia and Yennsylvania; but are most numerous in the Central State of Kentucky. They were called LICKS by the first settlers, because they noticed that bufialoes, elks and leer went to lick the saline ground, and SUCKS when they went to ruck or drink the saline springs or pools of the salses. The French settlers called them salines; this name has been partly preserved in New-York, anada, Illinois, and Missouri.

Nearly 100 licks are noticed in the large map of Kentucky by Munsell; but I liave seen or heard of 60 more. They may be divided into 3 series.

1. Salt Licks, producing saline efflorescences or salt springs and species are from the state us New-York, oftell dry, bit the saline particles 
limestone of milar to the wey but of a with a bluiah but petrified, - and can be

e without a cu. racliating form e, centre volid las rudiate from

Oblong, nearly ecl, encls round. evell, lamellas, 4 . Fine large inchea long, $s$ iriside.

Discoldal, de.

taide, lamellas and of a paler d 500 other fos. Iconographical

EIRAPIIY.

of Keniucky.

essav.

these places Physical Geo. te history to

ne is SAISF. the Western estern Virgibut are most tral State of were called tlers, because loes, elks and aline ground, went to suck ings or pools ench settlers is name has I New-York, Aissouri. e noticed in cky by Mun- heard of 60 ivided into 3

rcing saline springs and springs are ne particlea entst in the soil. Altho' sea salt is 10. to 12. Flat Lick, Fern I.ick and Bulthe most common, yet several uther ger's Lick, un F'ern or l'ond cr. 8. of 1.ou. galts mixt with it, Epsom nind Glaul iaville. salts mixt with il, Epsom nnd Glau. 13 . 14. Mann Lick and Elk Lick, s. of

muriates. Few licks affiurd the pure 15. 16. Clarer Lick and Tar apring muriate of soda.

2. Sulphur Licks. Those where 17. 10 20. White Lick and 3 other on

sulphates and hydrogene predomi- Highland cr. Clear Lick, at fork of Clear cr. and nate, rendering the soil or water Tradewater cr.

fetid.

3. Clay Licks. Where clay or II. Group.-On the two Sandy Rivers. marl chiefly aboundus often partly Itummer Lick in Beaver cr. in knubs, Cats Lick and lligpaint Lick on the cr. saline, and licked by wild beasts o tame cattle. 'T'se paint licks have colored ochres.

25. 26. 27. On Ititle Sandy, 3 Salt

Nay, these 3 kinds of licks are ret Lick. Mucli sali made. often near each other; at inud licks III. Group.-Licks on Licking river, for instance, 4 springs, salt, sulphu. which took its name from them. All in ric, vitriolic and clialybeate are the limeatone region.

found. not called licks, because the cattle head of the fork.

do not lick them.

30. Grant Lick on Philips' cr. brancl The licks are known at first gight of main fork.

by their barrenness, as littlo grass, 31 to $37 .^{\circ}$ On Middlo forks. Upper and lew plants lower Bluc Llcka, salt and utony. Cow ew plan and Slate Lick on Cow cr, and Slate amung thein, being commonly desti- cr. Mud Licks or Olympian' Springs, tute of soil, and forming therefore uprings as stated on a brouk. Station Lick many small barren spots among the and Burning Spring Liek near the liead. fertile lancis of Kentucky, frum $100 \quad 37$ to 47 . Ten Licks on auth fork. Fork Lick on Forklick creek.

yards to one mile or more in extent. Four Licka below Cynthiana.

But few are stony; they are gene- Farrod's Lick on Ilarrod's cr. above rally formed by a thick stratum of Paris -2 Stone Licks on Stoners fork.

clay, from 3 to 100 feet high, raised Curliale J.ick, one mile W. of Carlialo in leaps, slopes, hills or hollows: on Lisk cr.

perpetually waslied by rain into gul. Hinkaton Lick on Hinkston fork.

perpetually waslied by rain into gul- IV. Group.-Licks on the Kentucky unsliaded heat of the sun.

To enumerate them properly, as 48. Burning Spring at the source of counties are yet fluctuating in Ken- Burning Spring fork of South fork.

tucky, I have disposed thein in 749 to 53 . Five licks near Manchestcr groups, according to their situation and South fork, all Ssit Licka, where near streains. Lick, Outlaw Lick, Elieha Lick, Redbird Enumeration of all the Licke of Kentuch.y. Lick.

1. Group. Near the Ohio river. $\quad$ 54. Estil Springa and Licks near Ir1. Salt lick near Vanceburg and mouth vine.

of Salt Lick Creek.

Sick near mouth of Trouble-

Lick Creek. .
3. Briarpatch Lick on Stony creek, N.
Lick and Rock Lick on 4 iorka of Station S. Dick and Rock

4. Sand Lick on creek do. oppnsite 60 to 64 . Paint $L$. White L. Bir and mouth of Miami.

5. Double Lick on Woolpers cr, \& do. Paintlick cr.

6. Biphe Lict on cole 65,66 . Silver Lick and Rocky Suck

7.8. Mind hick and Upper Lick on on Siler cr.

9. Paint Lick on creek do. S. of 6.98 , Glen's Lick F. of Frankfort 1 mile. 
69. Cedar lick on Ceclar er.

70. Clay Lick on the Kentucky E. side 71. Drennon's Llck on 1)renuvis cr.W. side.

72. 73. Deer Licks on Mill creek.

74 to 79 . Near llick Miver, 6 Lick nig knob Lilck the moat remarkable, a 133 to 135 . Salt L. on rake cr. 8alt fine aslae of marl of late formation, near. made. Sulpliur $L$. and ' rummel $L$. on ly 2 miles round, with craters, \&ce. I.ittle forkn of I)rake er.

knob Llek at head of Knoblick cr. Kast 136, 127. Licks on Noble cr, and Dif. Knoblick on Liek brancli. Shelby Lick ficult cr.

on Knoblick cr. Fall Lick on Fall cr. 139 , 140. Two licks near Chaplintown Boon's Lick between Mt. Vernuil and and Saltpeti'e cr. and cave.

Crab orcharcl has alt wells.

80 to 87 . On lled liver, 8 licks or more, all In the Knobs. Alum Lick and Iron L. near tlie Iron wurks. Catamuun J. Red L. \&ce, abov'o sliem.

141 to 144. Four Lleks on Faat fork of Harren liver.

88 to 92. Near the Bilkliorn cr. Huftia. Vil. Group.-On tho watera of Cum loe atempling ground,. Sulphur 8prings. rikhorn Lick on North Elkliorn. Lane's Licks 2 or Lane's run.

93, 94. Big Lisk and sper

93, 94. Big Lick and Spenc

toglo cr. near eacli nther.

berland liver in E. Kentucky in $\mathrm{Knob}$ hills clisefly.

145. Hollow $\mathrm{L}$. at the source of Cum berland lliver, near the llollow $\mathrm{mt}$. in Cumberland mis. branches.

95. On Lick fork of Floyd cr.

95. On Lick fork of Floyd cr.
96. Lon Lick on Lcaglick cr.

96. Long Lick on Lcaglic

98, 99. On Simpaon cr. 2 Lleka.

100, 101. Dry L. and IIarrod's I.. nes

Hurrodaburg

102 to 105 . several licks or brandie

of Beeclifork.

105 to 110. Several on ltolline furk i tho knobs chiefly. Falling run l. Pine L. at head of Pottinger cr. Two sulpluur N. and's. Salt I. on 8alt run liear Mu draugh hill, Cedar L, betweeu Now Le 146. Yellow L.

iar the Cumberland Gap.

147. Morgan L. on Cumberland be Rivers.

Hivers. boursville.

149. Hacenon $L$ In Knobe at head of tichland cr.

150. Flat L. on Buck cr. to N. E. of Somerset.

151. Fighting $I$, at the forks of Fight. ing cr.

152. llennick $L$. above Burkaville. 153. Salt $J$. in Saltlick bend $B$. of Burkaville.

banon and New-Market.

154. Sulphur L. un Sulpluur cr, branch - nf Ohio liver.

-

and branchos. From the head to the Mt. Vernon. Double L. and Horee L. on and branc 111. Long $L$, near the surce, giving riae to Long branch, and slso to a branch of Dick R. In the Knobs. 112, 113. Moeasain $L$. two near head
. In the Knobs. loraelick cr. Birch L. Indian L. and of Green R. and Mocasain cr.

114. Pise $L$. on cr. asme name.

115. Locuat $L$. on Locuat run of Pit $\operatorname{man} c r$.

116. Rock L. on Brush cr. aurel $\mathbf{L}$, on Laurel fork of Laurel $\mathbf{R}$.

Some other nameless licks may exist in Kentucky. When very sinall or quite dry, they often pass unnoticed, and many Sucks are now called Springs. I have seen many such which it would be tedious to 17, 118.

317, 118. Elk L. a dripping rocky lick, Licks become Sucks sometimes Sul on Little Barren $R$ 119. Clay L. at the head of Bear cr. 120 to 122. Wolf, Duck and Elk I. o 3 forki of Muddy kiver.

123. Alaton I.. on Aliton cr. brancls of Pomel cr.

124. Otter L. on Otter cr. brancls of Pond cr.

125, 126 . I.ong $L$. and Sulphur L. on

two branches of Rough River.

127. Big $\mathrm{L}$ on Pather

128. Deer $L$. on $N$. furk of Deer cr. in the Winter and Spring, in rainy veather: and many Sucks, become licks in the dry season. Some mi. neral springs were formerly eucks, wch is the Cameleon spring in the knobs near the Mammoth Cave. Deer and Cows now frequent the Licks to iick the ground.

The Spouting Springs and Burning Springs of Kentucky although 
D.ranclies of cof Gasper II. $R$. ek fork of do. igreell. alke cr. 8alt ummel L. un - cr. and Dif. Claplintown $n$ Hast fork of sters of Cum. aters of Cum.
icky in Knob urce of Cum. llollow mt. in of Yellow cr. imberland bend Rockcastle cr. 1. of Barbe at head of ir. to N. E. of forks of FightBurkaville. kend 8 . of hur cr. branch rear hookcastle cr. ditto, N, of nd Horae $\mathrm{L}$. on Indian L. anc of Laurel $\mathbf{1 7}$. When very ey often pass sucks are now c seen many be tedious to

ks sometimes ring, in rainy iucks, become n. Some mirmerly eucks, spring in the nmoth Cave. frequent the freq ngs and Burnucky although
White in Mexico at 18 to $19 \mathrm{~d}$. N. of commonly connected with the licks, the Vifuator, all vegetation ceases at are but few and peculiar phenomena. 14,075 feet.

The lescriptiou of the inost re- The Imalaya mountains of Aaia evince The de wiven here. alsu that other causes besides latitude and markable I.icks will be elevation, influence the elimate, heat, after in a geological Fssay. though few are alike in extent anil vegetstion to $30 \mathrm{~N}$. cultivation extends as form they have nevertheless many fur 17000 feet above the sea, and per. form, they have nevertheless man as 17000 feet above the at 20,500 feet,
thing in common.

T'akLos.

21. The troo Higheat Mountains of Ameri ca.-By Peniland.

They are both in South America and 22. Scientific Fisplorere of North Amertca.

1. Mr. Lutner, a Butanial and Entumoin Bolivia. 1. Mount Sorata, hast of is 25,250 feet yet lower than the peaks of the this year in Imalaya in Asia. Peak Javaher is 26,745 ho expects to bo sent next year to Aus. anil others from 27 to 28,000 . City Lapaz tralia by the Botanical Society of stutt. 2. Mount Illimani, Eaat of City Lapaz gar

is 24,350 feet high, and the second hiph- gard. Mr. Gates has explored for two est in Amerien, whilo the lamed Chim- 2. Mr. Gatesiana, Misaissippi and Alaborazo, once thought the highest on years past Loulanaso of several gentle. earth and lately the highest at least in bama, clicfly in New.York. Ile lias colAnicrica, la at beat the third in mank, shello, fos. being only 21,425 feet hich. Perhapa lected ond other objecta.

are to be found in Boli. sila, and oller objecth sith company of ad. vis and Chili. Pentland in 1825 measured the moin- venturers from the Pacific Fur Company, Pend heights of Bolivia, and fonnd aetta, acnt by the year to explore the them higher than those of Quito, near have departed try, where they are to apend the equator. The higheat land of Ame- Oregon Country, whe and irading. It is the equate the S. of it, whilo in Asia it is fire yeara in hunting and lrading. Zoolo$\mathrm{N}$. of it.

nist among them; but their namen are This discovery upaeteal views of moun. not given. 4 . Prof. Rafineaque has been one of tains whinh muat bo amel books. the earliest scientific explorers of North at our geographical schol Pentland de. America. He has travelled fol 20 GeoAnother discovery nf Polaniat, Zoologiat, Geolog 1802 to stroys the whole of limits of congelation grapher and Archeolog 1832 , in the fol. theory of gradual thow. Thus every learn. 1804, and from 1815 to 1832

and perpetual anow. Thalually deatroy. lowing states and placea.

ed theory in gcolugy i go2. Pennaylvanla and New Jers

ed by facts. On the Andes of Quito at only at 1804, Melaware to Cape Henlopen, the perpetual enow is a bast and West Maryland, Virginia, Alle15,749 feet. While in the Amea Equa. ghany mta. of Pennayl. and New Jeracy. changecticul and New.York. 1816. New. York, Lake Champlain, the 17,061 feet ! by the theory it ought tu be 1816. Hudeon, Vermont, \&c

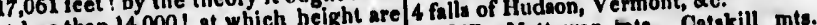
at leat than 14, Mattawan mts. Catakil

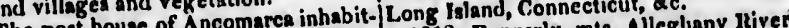
The poat house of Ancomat 15,722 ft. 1818. Pennaylv. mta. Allegliany Tiver ed 4 monthe in tho year, is at 15,722 farura at Ohio to Wabash, West Kentucky, I

14,252 feet.

14,252 feet. mines at is,912.

mta. River Ohio, Knoblillia, \& ec.

City of Chuctito at 13,025 feet.

The Lake Titicaca inliabited all around 1820. Central and Ohio, Miami, \&c.

is at 12,703 feet. The table land of 'T2- 1821. Kenticks, Oheky.

is at 12,7 182 . Central Kentucky. 'Tenneasee;

Jora

Lapaz,
$12,195$. 
1824. Central Kentucky.

Descript. A fine large tree 20 feet 1825. Ohio, Western and Northern high in 20 years growth. Bark very Virginis, Maryland, Pennsylv. Kentucky, 1826. Ohio, Lake Frie, Falls of Niag- der with a geeyish brown bark, buds ara, Canada, New-York from Buffaloe to small rufous, with obtuse scales. New-York, Pennaylvania.

Leaves like those of apricot, but

1827. New-Yórk, Massacliusetts, Bos-
. ton, \&c.

1828. Allegh, ints, Celigh, Schooles mts. New Jersey and New.York.

mts. New Jersey and New.York.
1829. New Jersey, New-York and Con necticut.

1830. Catskill mts. New Jersey, \&c.

1831. Delaware, Taconic mts. \&c.

mucin smaller, abont one inch long.

not so smooth, a little rough, but not

pubescent. Blossoms in May and

produces a profusion of white flow-

ers with a fine smell of honey. The

cherries are ripe in July, small, one

cherries are ripe in July, small, one
fourth of an inch long, elliptical

looking like small wild plumbs; but

$\theta$

23. Botany and Horticulture. Extracte of a letter fiom $D r$. John Torre of New York, 10 Prof. Rafinc'sque Philadelphia, March 1832.

I have lately received some of your new plants from Ohio, and also from Kentucky, sent by Mr. Eaton. Your Cladrastis is certainly the Virgilia of Michanx, it must be separated from the Exotic Virgilias, an your name (of 1825) is a very good one.

Stylypus has interested me very much, the stipe clianges in appearance in different periods of inflo rescence.

Enemion is listinct from Isopy mun; but the I. thalictroides of Germany may perbaps belong to it Mour E. bilernatum I suspect to be Your $E$. biternatum I suspect to be and Delessert Ic. t. 6. collected. by Michaux; but without seeds; while the seeds make this genus.

2i. Descrips psion of a netw eherry iree from the Oregon Mountains.

I noticed as early as 1829, in Washington Square of Pbiladelphia, a fine tree said to have been brought by Lewis and Clarke from the Ore gon or Rocky Mountains. I ascertained that it was a n.sp: and sent an account of it to Decandolfe in 1830 I call it Prunus (Ccrasus) rotundifolia. Arborescent, leaves rounded, base often subcordate, end obtusely acuminate, margin aerrulate. Flow ers fasciculate, berries oblong sinnll and black. bluck soft and sweet when ripe

Good to eat, but if too many are eaten causing sickness in the stomach, like all the wild cherries.

Stone oblong acute as in plumb, but

vithout the 3 keels as in cherry.

I think that I have seen the same ree in West Kentucky in hills; but I did not see the fruit there. It may

be found fiom Kentucky to Oregon.

It is now naturalized in Pennsylva-

nia, and may probably be improved yrafting. Birds and children are ond of the fruit.

C. S. R:

25. Account of $2 \mathcal{N}$. Sp. of Dionea or Tenus fy trap.

This beautful genus was supposed o consist of a single sp.; but out of many plaxts brought froin Carolina and Florida to our Philadelphia gàleners, I hive detected 2 new ones D. sessiliflora and D. uniflora. ters.

1. Dionea muscipula L. Petioles cuneate broadly obcurilate at the end; flowers corymbose, 4 to 9 on ong peduncles, biacts linear.

2. Dionea sessiliflora, Raf. 1830. Petioles winged, oblong or subcuneate narrow; acute at both ends; flowers "sessile, 3 to 5 aggregate, bracts lanceolate. Observed in the Botanical Garden of Macarran in blossum in Muy 1830. The true leaves are bilobe and ciliate as in the first, they also catcli flies. Scape terete clongate, flowcrs white with shurt concave bracts." Divisions of the calyx lanceolate acute, Capsules 
tree 20 feet

Bark very nchlets slenn bark, buds tuse scales. apricot, but e inch long, bugh, but not in May and white flowhoney. The if small, one g, elliptical, plumbs; but when ripe. oo many are 3 in the stoild cherries. n plumb, but as in cherry. ten the same in bills; but here. It may $y$ to Oregon. i Pennsylva. be improved children are C. S. R.

- of Dionea or cp.

was supposed p.; but out of roin Carolina adelphin gà)-

d 2 new ones uniflora.

ctive charac.

L. Tetioles ilate at the e, 4 to 9 on linear.

4,Raf. 1830.

gg or subcu-

both ends;

5 aggregate,

erved in the

Macarran in

The true

ciliate as in

flies. Scape

( white with

Divisions of te, Capsules

hardly longer oval acute. As pretty|Franklin tree, Gordon tree, Stewart as the old sp. and will be a fine ad- tree, Bigleaf Magnolio, and several dition to our gardens. Brought from other Southern trees. In my MediCarolina or Florida.

cal Flora several new plants were

3. Dionea uniflora, Raf. 1830. described from this garden. I now Petioles oblong acute winged, Scape propose to give periodically the deunifiore, bracts linear. Also from scription of many others, which the the same garden and place, perhaps liberal owner has allowed me to exa variety of the last; but smaller, amine, describe, preserve and draw. leaves shorter and broader. $\quad$ I may give their figures hereafter; C. S. Rafingsque. meantime I give above that of the

FRANKLIN TREF. FR.ANKLINIA ALATAMA. garden. The original tree brought by Bartram nearly 60 years ago is now nearly 40 feet high. All those in other gardens come from this tree. Their sweet white blossoms and orange-like leaves make them highly ornamental and prized.

1. Veronica precox, Raf. Stem liffuse compressed probescent. Lower leaves opposite, upper alternate, on short petioles, ovate, rounded, serrate-laciniate, trinerve. Peduncles axillary solitary longer than leaves, cspsules compressed emar. ginate. Annual Vernal in March and April, lasting only a few monthe, Grown in the garden from seeds re. ceived from a place unknown; but has spread all over the garden like a weed, and even is become sponta. neous on the banks of the Schuylkill. A pretty small vernal plant, with delicate large bluish blossoms. 2. Veronica Sparsiflora, Raf. 1880. Stem erect, simple round solid, leaves opposite sessile cuneate, oblong entire obtuse. Raceme terminal lax very long, flowers scattered, 26. New Plants from Bartram's bracts linear oblong obtuse, pedicela Botanic Garden. filiform. Capsules bilobed subcom. Br C. S. Rumsereve.

The Botanic Garden of Bartram 7 s or Texas, received from Prof. at Kinsesaing on the Schuylkill, 2 Nuttall. Stem 1 or 2 feet high. milea from Philadelphia, is the old- Flowers vernal purpurescent, hand. est establishment of the kind in N. some. Corolle rotate, segments of America, begun over 100 years ago the calix unequal oblong obtuse. A by the elder Bartram. It is yet injpretty ornamental sp.

a very fourishing state under the 3. Cotyledon marginatum, Rat: management of $\mathrm{Col}$. Carr and his Leaves crowded patent sessile spacons very rich in rare Southern tulates oblong acute thick, conves plants and shrub\%. There have been beneath, flat above, margin acute unturnized in Pennsylvanin, the brown. Scape terete with \&or $\$$ small 
leares orate acute. Flowers in pa-feach extremity in the neighbourniculate spikes naked. Corolla cain- hood of four springs of water, which panulate, 5 fid 5 gone. Fine pe- rise from the loot of steep cliffs on rennial green house plant received the North side of the Village.

from Mexico. Blossoms in sunimer, The interior particularly at the corolla acute, safiron color. Scape Eastern end contains the ruins of nearly $2 \mathrm{ft}$. high, calix 5 parted acute. Inany houses of various sizes from 10

4. Maranis obliqua, Raf, Petioles to 30 feet diameter, all of circular terete scabrous, leaves broad lan-form. Througlinut the whole Vilceolate, base oblique, end acuminate, lage graves are found in abundance, lucid above, glaucois beneath, very from one to three feet in depth, and omooth. Perennial from Florida or containing human bones of all comBrazil.

mon sizes. The bodies seem gene-

5. Iris aurea, Raf. Stem straight rally to have been buried in a sitting biflore, leaves longer broad ensiform, posture, with flat stones placed end acuminate falcate, flowers ge- around and over them. Cups and minate beardless, 3 petals obovate small ornaments composed of earth entire, 3 lanceolate undolate, stig- and shells are found with the bones. mas dilatated notched. Discovered Several small hatchets of very hard by Mr. Carrin a pond of the Pocono stone, and of various shapes have $M t$. in the Alleglanies of Pennsylv. also been found. Other sinall polVery near to Iris pseudacorus of Eu- ished stones, weighing from half a rope, which however has bifid tooth- pound to 2 peunds, designed from ed stigmas, \&c. Large Iris 3 to 4 appearances for breaking nuts, are feet high, with scentless flowers of frequent.

aright golden yellow, smaller than No metal of any kind whatever in I. pseudacorus. The 3 inner petals has been found in or about this Vil. shorter than stigmas, equal to An- lage, al though much search has been thers, casules oblong deeply sulcate. made.

\section{(To be continued.)}

$+\infty$

\section{ARCHEOLOGY.}

27. Some Antiquities of 'T'ennessee. Br M. RuEs. The following description of two
ancient towns of the former inhabibanks formed by the uprootin tants of Tennessee, was given us of other trees of equal size and age. for publication by Mr.M. Rhea, the From which may be inferred that author of the late excellent map of many centuries must have elapsed, Tennessee, with a geological section since the population of the place confirning our geological survey of ceased to exist.

Kentucky, and noticing a stratum of Oolite near the top of the Cum berland Mountains in Tennessee.

On the plantation of A.I.ong, Esn st miles South of Columbia, in st miles South of Columbia, in
Marny co. 'Tennessec, are seen the remains of an ancient town or village, containing six or more acres. The form is elliptical, extending. East and West. Surrounded on The elevation is extremely regular, the South East and West by a the height about ten feet, with a fiat wall of clay which terminates at surface, and steep, almost perpendi- 
neighbourater, which ep cliffs on Ilage.

arly at the the ruins of zes from 10 of circular whole Vilabundance $n$ depth, and of all comseem genedin a sitting nes placed

Cups and ed of earth th the bones. of very hard ahapes have $r$ sinall pol. from half a signed from ing nuts, are

nd whatever bout this Vil.

arch has been

trees grow. vere removed the last few ards of two ions. Some and growing se uprooting ize and age. nferred that ave elapsed, of the place

of Big rock oe river in see, are the rge ancient aral appearbed. Near rge mound, rectangular sides pointhe heavens. ely regular, - with a flat it perpendi- cular sides. The exterior has not/29. econoux on sciavos or wrasta yet been penetrated.

28. Somk Antrauities or Ohio. to produce and which teaches how Notwithstanding the long account carefully husbandiug and employing of the monuments and ancient towns the SAvings of Industry: whereb of Ohio by Atwater, in the Archeo-industry itself, with moral happilogia Americana, and my own sy-ness, and social comforts are also noptical account of the ancient mo-promoted.

numents of North Ameriea; there Among the many institutions to are many more as yet unnoticed, of which this art has given rise, the which I sliall now describe two. Beneficial Societies and the Savings'

1. Near Alexandersville, 7 miles Banks are the most conspicuous and S. of Dayton in the Valley of the useful; but some others less known Great Miami river, the main road are not less so, and there is room for

- from Cincinnati to Dayton, which I several new ones on improved travelled in 1826 , crosses the site plans.

of an ancient town, of about 500 Having paid peculiar attention to acres extent. It forms a perfect this gubject, written an analysis of ellipsis, nearly one mile long, from this art, and found some new imporN. to S. It is surrounded by a wall tant principles of it: we propose to or embankment 25 feet broad and 8 inyite the public attention to it very feet high, without any ditch outside speedily in a more impressive form; nor inside. It has 3 gateways to the when we have visited the new inatiEast, West and North, this last is tutions lately established in Balticlose to the River Miami, which has more; where these principles were partly washed away the embank-firat made known by us in 1825 .

ment. By its size and shape it could Meantime we merely atate now, not have been a temple; but rather that the two fundamental principles a town. I could see no mounds nor which we claim to have discovered altars near it. It is very old, the and published in 1825, are,

walls being rounded, covered with 1. That every dollar and cent soil and large trees. gaved by industry, frugality and 2. At the mouth of Grand River care, ought to be invested with the on Lake Erie, where now stands the property of accumulating at aimplo town of Fairport, stood about 50 or compound incersst, by converzion years ago, an old Indian fort, ex-into Stocks!

actly of a pentagone shape, with une- 2. That avery yullic or private qual sides, inciosing several acres. Stock cousisting of such Savings, The wall was of rough stones, partly ought to be divisible 2: pleasure into cemented,but covered with soil, and any requiren smount of tellars and trees 300 old were growing on it. cents. Whicreby any savirgs beThis account was given me by an come convertible into piriuctive old settler and is rather obscure. Stocks, and any surh Strcks converThe stone wall, with a kind of ce- tible into fractions available as moment is rather singular and doubtful. ney or remittances.

This may have been one of the forts It is evident that auch ample and of the Erigas or Erie's Nation, useful principles cannot fail to inbuilt for defence against the Sene- terest every body that can save a cas, who drove them off South of penuy out of induatrious earnings: Ohio in 16.50; but it was far more nor tail to be applied evisy where, ancient; the trees showing that it when more generally understood, ss had been left, soil formed and trees they have already partly beca apbegun to grow towards 1475 . plied in Baltimore and Boston.

C. S. $\mathbf{R}$ plied in Baltinore and (G. B. $\mathbf{R}$. 


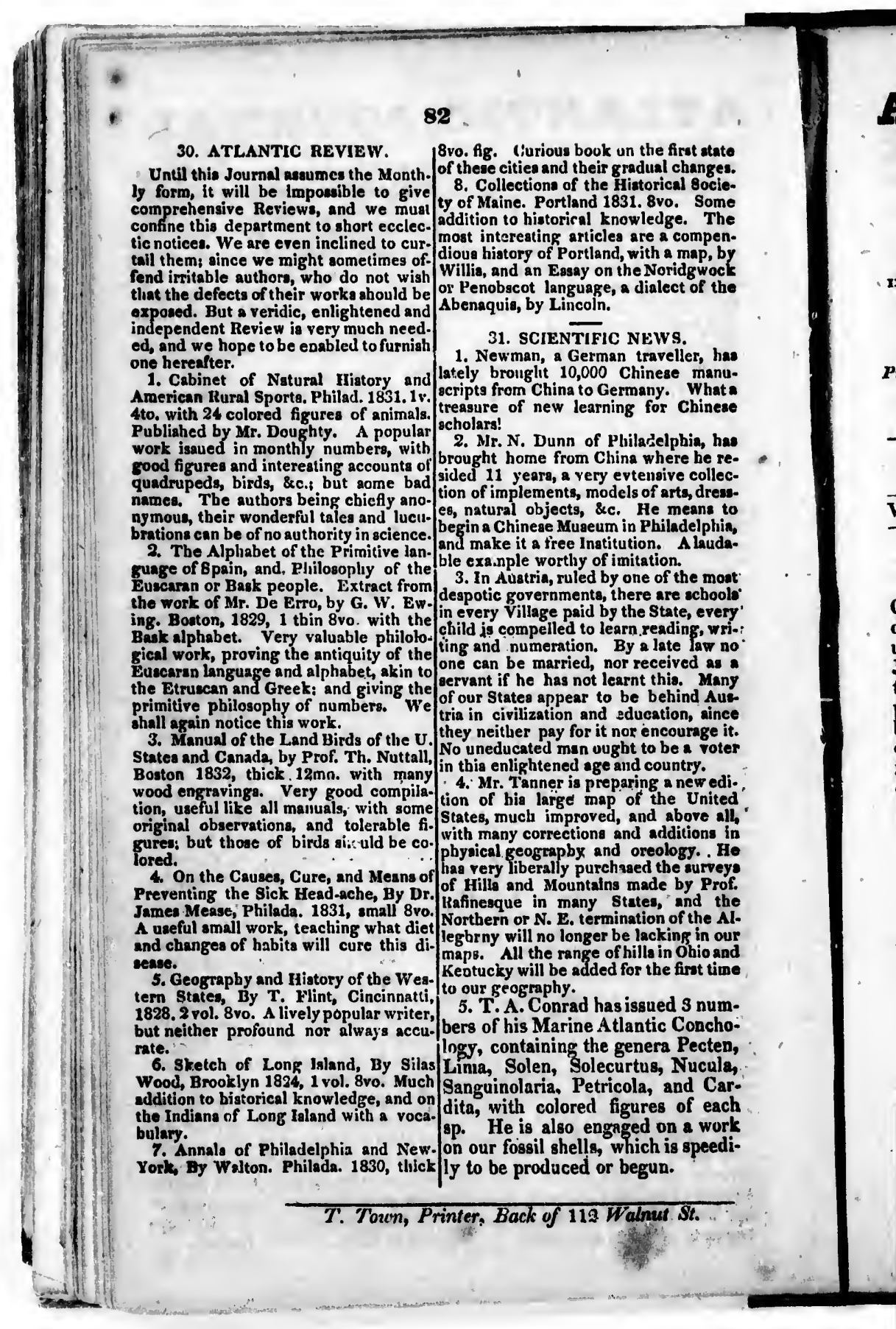




\title{
ATIANTIC JOURNAT
}

\author{
AND
}

he first state

ual changes.

rical socie-

8vo. Some

edge. The

a compen-

h a map, by

Noridgwock

alect of the

:ws.

aveller, ha

hese manu-

ny. What

ny. What

Jelphia, has

where he re-

insive collec.

fi arts, dress.

hiladelphis,

n. Alauda.

tion.

of the moat:

are achoolo

State, every

eading, wri-:

late law no

ceived as a

this. Many

behind Aur-

sation, since

incourage it.

o be a voter

country.

g a new edi-

d above

additions in

eology. . He

the urveys

de by Prof.

8 , and the

on of the $A l$.

skings in our

in Ohio and

he firnt time

led 3 num.

ic Concho-

ra Pecten,

b Nucula,

and Car.

of each

on a work

is speedi-

n.

At. St.

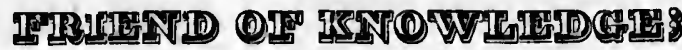

A CYCLOPEDIC JOURNAL AND REVIEW

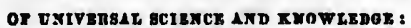

GISTORICAL, TATORAL, AND MEDICAL ARTS AND BCIRNCES

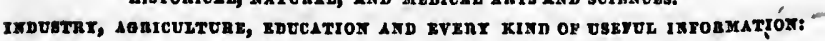

EDITOR, C. S. RתFINESQUE,

Professor of Historical and Natural Sciences, and Member of several learned Secieties in Paris, Brussells, Vienna, Naples, Bonn, New-York, Philaclelphia, Cincinnati, Lexington, Esc.

Xnowledge is the mental food of man.

Vor. I. PHILAD. SEPTEMBER, 1832. [ExTRA of No.3. NOTICE.

lit. 5 thly, We give below a list of Tre appearance of the Spramodic $\begin{aligned} & \text { agents in some places to whom the } \\ & \text { money inny be paid. 6thly, In case }\end{aligned}$ Cholera in Philadelphia, having in- of need, the agents of Stkinson's duced the Editor to lengthen Iik Saturday Evening Post, and Casket, usual Suminer Excursions, during well as of the Journal of Health July, August and September, tlie may be applied to, and the 81 paid third number of this Journal (not. them, karming our friend Atkinson printing) will only appear in the of it, whic they write to him and beginning of October, and is pre-remitting tho same.

ceded by this Extra Number. The In all those uqses, whenever we fourth Number sliall appear in De-shall hear of $\$ 1$ besug paid or secucember. Both sliall only be sent to red, the Journal shali be sent, with those who have paid or sent the the back numbers, to neve subscrismall subscription amount. This bers as long as they can be nupishExtra Number is intended as a ed. Price $\$ 1$ per annum on 4 ntrawarning to those who have neglect- bers, or $\$ 2$ for 12 numbers forming ed this, and as another sample of a volume of 400 pages and many the contents of this Journal, which figures,

will appear to deserve, as they have already partly received, the warm CONTEN'TS FOR THIS YEAR. appiobation of all the liberal friends This Journaz is dedicated to all of knowledge and science. Great the sciences and branches of knowdifficulty having occurred with sub- ledge; but chiefly all the historical, scribers in forwarding the small philosophical and natural sciences, amount of subscription, we recom- on which it contains more new mamend again to send us 82 , in which terials and details than any other case we are willing to bear the heavy Journal of a similar size, nay perpostage; or else to join five together haps as many if not more than some to send us 85 for tive subscriptions dearer and bulkier. Above all it in one place. 3illy, To send 81 by gives chiefly materials concerning: a friend coming to the city. 4thly, America, and has nearly as many To pay it to the Postmaster, and re articles on Teology, as the Ameriquept him to send it or inform us of can Journal of Geologs. 


\section{4}

In proof threof, it is sufficient to |Age of Mountains. On Crystallizanotice the principal subjects and es- tion. Origin of Sand and Sandsays contained in Nos. 1, \& 2 , or stone. Geological regiuns of North that will be found in Nos. 3, \& 4. America, \&c.

Geviral Knowlenge. Latent Ameluoas Oryctology. Vulknowlerlge. 'Táxes on Knowledge. gar names of fossils. Silicious fosCheap Books. Employment of sils. On Geodites. On Cavulites Wealth. Inpediments to Know- and Artrosites. Genera of Ameriledge. Primitive Discoveries, \&c. can Trilobites. Lamellites, N. G. Educstros. Free Institutions of Lucilites, N. G. Flexurites, N. G. Paris. Principles of Fellenberg. Nevryctes, N. G. of Encrinite. Principles of Jacotot. Institutions Odocoileus, N. G. of fossil teeth. needed in America, \&c.

Fossils of Sherman Creek, $50 \mathrm{Sp}$.

History. Of China before the Fossils of Olio and Kentucky. Fosfiood. Early Colonies. Cradle of sil Trees and ferns, \&c.

Mankind. Asiatic Negries. Po- Mastology. New Jaguars and lynesians, \&c.

Couguars. Two new Moles. A

American History. American new Otter. A new Shrew. Bats of

Nations. Atlantic Nations. Ame- North America. New Squirrels. rica before the flood. Primitive Ne- New Field Mice of Kenturky, \&c. groes of America. History of Zapo- OnNitholoax. New American tecas. Domestic Animals. Histo- Engle. Sea birds of Kentucky, \&c. ry of Shawanis. Laws of Lolloway. Expejur.ocy, 'Two Salamanders ry of Shaw History of the Iroquois. of Kentucky. Two New Lizards, Last Indians of Virginia and New- of do. Two N. G. of Turtles. SeveJersey. The Americans are nothal Snakes, \&c.

Jews, \&c.

IснтнiоLogy. Supplement to the

Amerions Antrauities. Lecters/Fishes of Olio. New Fishes of to Champollion. Alphabets of Ly- Lake Erie. Of the Rivers Susquebia and America. Anéqquities of hanna, Potomac. Delaware. Inland Tennessee. Of Ohij. Of West Fisheries of the U. S. \&c. IchthyoloKentucky. of Missouri, \&c. gical regions of N. Anerica, \&c.

Philolocy American Langua- Extomology: On 15 Mosquitoes ges. Origio ut American Language. or Culex of North America. On the Philosonity of human Speecl.. En- Ants of do. \&c.

glish Homonyms and Synonyms General Zoology. Letters to Iitters to Klaproth. Vocabularies Cuvier, \&c

of Mandans, \&c.

Meteonology, Climate of Ge- Botany. Letters of Agardh and nessee. Physical phenomena of the New Cherry Tree. New Dioneas. Cholera. Singular Meteors. New New plants of Bartram's Garden. Theory of Tides, scc. Grology. Caves of Kentucky. plants of N. Am. from my herbariStrata of Ohio and Kentucky. Geol. um. Subterranean plants, Botaletters to Rronguirst. Salses of Eu- nical Letters to Decandolle, \&c. rope and America. Licks of Ken- Agriculture and Horticulttucky. Genlugy of Alleghany Moun- ure. Plants giving Oils. Best shrubs tains. C sil Mines of North Ame- for hedges. Sulfur in Trees. Double rica. Volcanic Theory. New Cave Crops. - On the several kinds of with fosil bones. On Oreology. Es- Mulberry trees. Subterranean horsential View of Geology. Feroe ticuiture. Melissa or Balm, \&cc. Ids. Coral Ids. Great Western. Mineralogy. Gold Mines of Limestone basins. The K hills. North America. Otsidian of PennLakes of Ohio. On the American sylvania. Friable Lignites. Coal Oolites. Geology of West Maryland. Mines, \&c. 
Astronomy. New Views on So- Alleghany, and from the Potomac lar Systems. On the Galaxy. Coin- to Einitsburg. In Pennsylvania, ets and 'Tychomes. Mathematics. Principles of So- Maryland line to Sherman Creek Mathematics. Principles of So- Maryland line to Sherman Creek
metry. Nunierical numbers. Bulk and the River Juniata, and from of Bodies. Oblique Mensuration, \&c. the mouth of Juniata to Westches-

Puicosoply 'Theory of the ter in a S. F. direction. On SherMind and Will. Emanation of $/$ man creek in Perry county, we have Beirigs. Analysis of Pythagorism. found a new and very rich locality Georaphy and Iraveluens. for fossil remains, where in one

Highest Mountains of America. week we collected about 50 differRidges of the Alleghany. Ancient ent species, of which a further acGeography of America. Ascent of count will be given in No. 3. We Mount Eina. Falls of River Cum- have found new localities for Obsiberland.- Mineral Springs of the dian, Lignite, and other rare mineUnited States. The Imalaya Muun-rals. In Ichthyology we have obtains. Douville Travels in Africa. served and drawn $25 \mathrm{Sp}$. of fishes Scientific Explorers of America, \&c. from the Susquehanna, and Poto-

Healtu and Mediuine. Chi- matc Rivers, with their affluents, nese Maxims of Health. Physical chiefly new specics. In - Botany phenoinena of the Cholera. Tables we have collected 1200 specimens; of liability to Consumption. Salt chiefly in the Aleghany ridges, and in IIydrophobia. Remedies for Can-have perhaps 5 or 6 new species. cer Consumption quite curable. We have visited the remarkable Medical Botany of the U: States. Cave of Carlisle, where fossil bones Mangers of Burials, \&c. Dangers of Burials, \&c.
Industry and EcoNomr. Nex and teeth were once found, one of
which we possess. We have also Science of Wealth. Plan of a six visited the Mineral Waters of Be'per cent Saving's Bank. Principles linch Maguire, Emitsburg, Carof Economy. 'Trades lacking in the tisle, Kennedy, \&c., of which we United States. Manufactures of the shall pubreh accounts, \&c.

United States. Stereography and

Pyrography. Duties of Mankind. The Primitive Black Nations of Theory of Population. Sets of Performers, \&c.

Artantic Reviews: Short AnaIrtical Reviews or Notices of about

lrtical Reviews or Notices of about Torks
60 late American Works. Miscellany. Scientific News. moir on the Origin of the Asiatic American Drama. Fragments of Negroes, I sent them last year two Memoirs; one on those Asiatic Negroes, wherein I demonstrated the Scientific Travels of the Elitor affinities of their languages with the in 1852.

Our Excursions have been chiefly well as with the Hindus and ChiOur bxculo and Central Pennsylvania, applied all the Negroes originated in the to Geological, Botanical and Zoo. Southern Slopes of the Imalaya to logical sure, rrom have visited. Baltimore and lound par many rare objects in the Cabinets of cond Memoir was on the Negroe or Dr. Powvell, Cohen, Hayden, \&c. Black Nations, found in America We have explored the Geology of before Columbus, wherein I proved Maryland from Baltimore to the their existence and connection by 
Janguage with the Negroes of $\Lambda$ frica 7. The Migrltas of Martyr in and Polynesia.

These Memoirs have been $r$

Darien, yet ering in Choco under

warded by the learned Society of Chinos. Ses Mollien. Ugly black Geograpliy, with a gold medal of or red Negroes.

Ge0 francy, which was lately communicated to me by Messrs War- nabi, blackieh with negro features den, our former Consul in Paris, and hair. Bee Stevenson.

and Jomard member of the Institute. 9. The Guabas and Jaras of Ta-

'This gratifying intelligence will guragalpa near the Honduras. See be acceptable to all my friends, and Juaics, \&c., now called Zambos. furnish another proof of my ability 10. The Emslen or Eateros of New to unravel at last, the origines of all California, ugly blackish Negroes. the American Nations and T'ribes, See Vanegas, Langsdorf, \&c. -

in pursuing the path which I have 11. The Black Indians met by opened, by comparing all the lan- the Spaniards in Louisiana in 1543. guages mathematically und numeri- See Suto's invasion.

cally with each other. 1. many, this fact of old Black Albinos, destroyed by the Clierokis, Nations in America will be new, and seen in Panama. Barton, \&c. yet it is an important feature of Among these the Yarura language American History, as well as the has 50 per cent of analogy with the existence of primitive White Na-Gauna, 40 per cent with the Ashantions there still more numerous. To ty or Fanty of Guinea, and about furnish a kind of insight into this 33 per cent with the Fulal, Burnu aubject." I will here merely enu-and Congo languages of Africa. In merate the Black tribes of which Asia it has 39 per cent of numerical I have found evident traces and ae-affinity with the Samang Negroes, mains in North and South Awerica. and 40 per cent with the Negroes of 1. The Ancient Caracob of Hay- Andaman as well as those of Austi, reprèsented as a Natiun of Beasts tralia or New Holland.

by the Historical Soxys, see Roman All this and ntany other details and Martyr. 2. The Calyurnams of the Carib thorities and compared VocabulaIslands, caried Black Caribs or Gu-Iries, in my Memoir.

enini $h$ others, are a black branch of Curibs. See Rachefort, Herreni, \&c.

3. The Arguahos of Cutara mentioned by Garcias in the West Indies, quite black. 4. The black'Aroras of Raleigh, increase in value, possess wealth or Yaruras of the Spaniards, ungly beyond their wants.

black or brown Negroes, yet exist- Liberal generosity is for them a ing near the Oronoco, and language duty; as well as a juclicious employknown, called Monkeys by their ment of their superfluous wealth or neighivours. income. Great wealth, unless pro5. (haymas of Guyana, brown perly employed, is detrimental to Negroes like Hottentots, see Hum- the State, and possessors, becoming boldt.

6. The Manginos and Porcigis the temporal or spiritual welfare of of Nienhof, the Motayas of Knivet, indiviluals.

\&c., all of Brazil, brown Negroes It is said that Monarchies periah with curly hair. See also Vespucius by poverty, but Republics by two and Pigaretta,
Th

thy

the

of $i$

pul

tioi

ans

me

the

pro

we

mi

fie

for

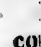

or

no

ral

w'

in

is

\section{de}


f Martyr in

Choco under or Gaunns or Ugly black a called $M a$. egro feature: son.

Jaras of Tanduras. See ed Zambos. steros of New ish Negroes. orf, \&c.

lians met by jiana in 1543 .

Negroes, and the Clierokis, Barton, \&c. rura Janguage

logy with the

in the Asliana, and about Fulah, Burnu

f Africa. In of numerical ang Negroes, he Negroes of hose of Aus.

other details roved by aued Vocabula-

W EALTH.

n the United ials, who by heritance, or irty, and its ussess wealth

8 for them a cious employus wealth or 1, unless proetrimental to rs, becoming freedom, and al welfare of archies perish blics by two idual hands.
This truism will often render weal- ptate, and whenever they become too thy men obnoxious to their neigh- rich, it may happen that to despoil bours and fellow citizens, unless them or destroy thein becoines a pubthey are known to inake a good use lic duty. No perpetuity can thiereof it. When they do they become fore belong to religious donations. public benefactors. Avarice and perpetual accumula- schools and libraries are good deeds tion is a vice, useless prodigality is and commendable. But to endow another: both extremes ought to be them riclily is wrong and pernicious. avoidecl. When chilalless, rich To help unissions and societies for men ought to cunsider the poor or tracts, temperance, peace, \&c. is the public as their children. When worthy of pruise; but must be blathey have a posterity or relatives to med if such religious societies are provide for, they must beware not to made tou rich; when something make them too rich and vicious, as wrong will always happen, and the wealth acquired by inheritance in- objects be often perverted.

stead of persoulal exertions is often True charity and benevolence connis-spent or squanderel. It is suf- sists in giving to the proor, the helpficient to providle a competence, a less, the aged, the cripple, the lame, share, ought alwnys to be set asile the blind, the sick, the destitute, for useful public purnoses.

But instead of waiting till cleath/happy-to relieve, help, feed, clothe, comes to snatch our posstexions, in instruct, support, and comfurt those order to give what cannot ine lield who are in need of nny thing. Not nor enjoyed any longer, how prefe- by giving mere trifles to beggars; rable it would be to do the good we hut by providing all the free instituintend while we are yet living: that turions of benevolence which are we may see it and receive the bless- required in a crowded society and ings of thuse we may benefit. There exuberam population.

is hardly any merit to leave by will The rich monopolizing the soil what can no longer be our own after and wealth of ye land, assunie the death. Wills besides, are sometimes duty of supporting those who canlost or set aside, or not properly com-n not acquire either. $x_{y}$ having the plied with; we can never be sure that means to do mucli good, $*$ becomes our good intentions will be fulfilled. their duty to do it. The bert gifts The best, safest and surest mode is are those which are of a permal to give while we live, that we may or perpetual nature, calculated to be see and enjoy the beneficial eftects useful not to one but to many, not of our charitable or patriotic purpo-for a day but for years or forever. ses: whereby we enjoy the reward. Although ostentation and pricle ses: whereby we enjoy the reward . Although ostentation and pricle
of good deeds by praise and esteem/may often mingle with public gifts in this world, and their eternal hea- as latent motives: yet cherity throws - veoly reward beyond this life. her veil over motives and accefis Some religious men try to buy the good intention. Patriotism dies heaven! either by wills or donations; the same and never asks for motives. but no bribe will take them there! Ostentation is only baneful when it God reads the heart. Good deeds gives with a blind hancl, to rich, alone are of any avail. What is gi- useless, fashionable or extolled instiven after death, not being our own tutions or individuals, insteail of then, is hardly a gift, but a mere le-poor, useful and meritorious ones. gal disposition. Free institutions for all usefol pur.

To pamper the church or sects is poses of the actual improvecl civilinot a good deed. - It is against the zation are needed all over the Unilaw of God that churches should be ted States. They abound in Europe rich: it is besides detrimental to the even in the most despotic countries, 


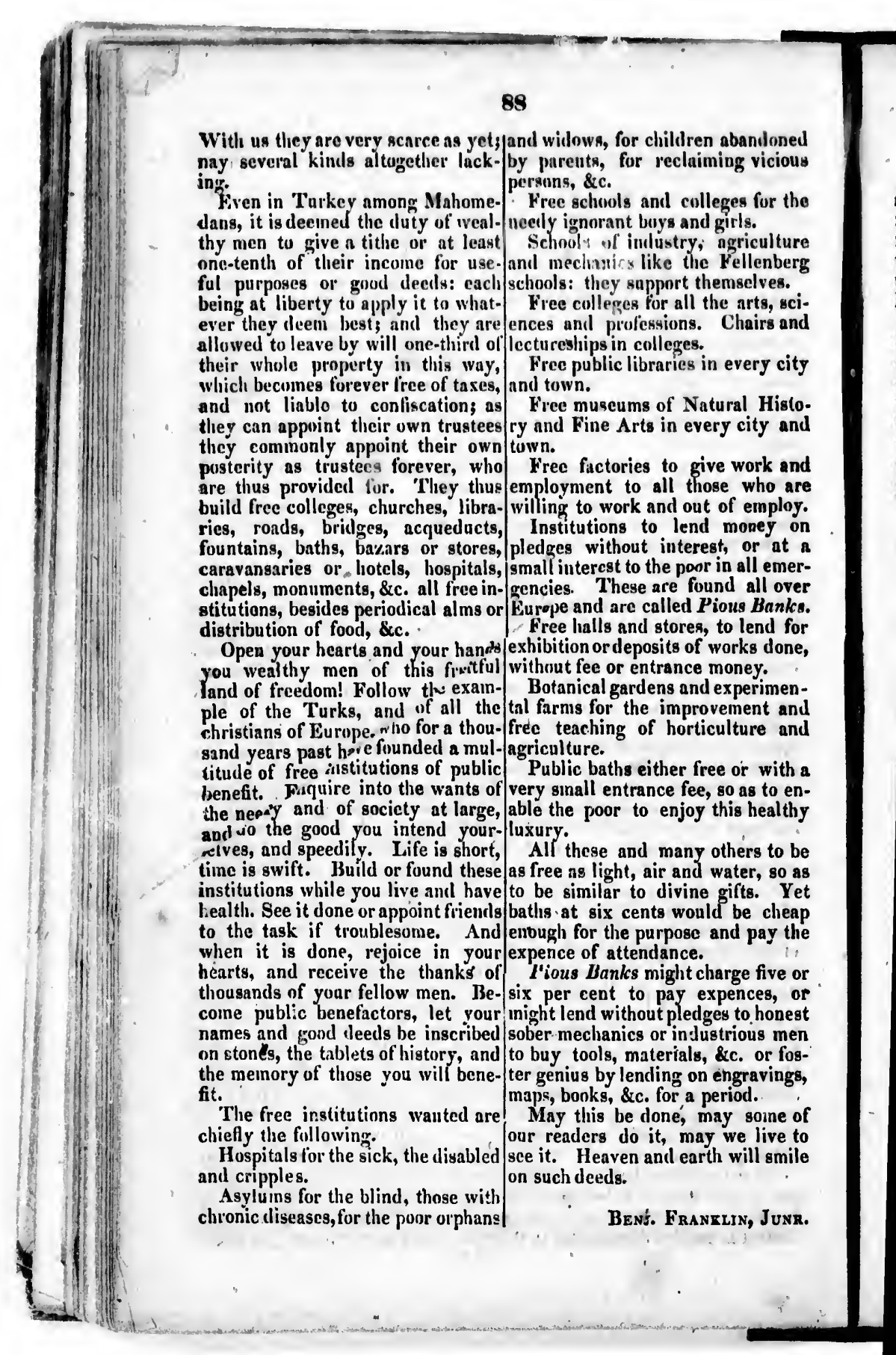


iildren abandoned reclaining vicious

ill colleges for the ys and girls.

ustry, arriculture ke the Fellenberg port themselves. or all the arts, scisions. Chairs and lleges.

raries in every city of Natural Histo. in every city and

to give work and all those who are and out of einploy.

- lend money on interest, or at a the poor in all emer. are found all over called Pious Banks. stores, to lend for osits of works done, trance money.

ens and experimene improvement and of horticulture and

either free or with a ince fee, 80 as to en. D enjoy this healthy

1 many others to be air and water, so as divine gifts. Yet nts would be cheap urpose and pay the ance.

night charge five or - pay expences, or ut pledges to honest or industrious men aterials, \&c. or fosiling on engravings, for a period.

done', may some of it, may we live to and earth will smile

Frantuin, Junr.
Savings' Banks at Baltimork. |Plan of an inpproved Savings InHaving visited these institutions, as proposed and announced in $\mathrm{Nn}$ 26, when I mate known there the Savisos Ixstrutrios or Nontu true principles of improving these $\mathrm{A}$ Maıcs.

useful establishments, several new 2. Every individual may deposit institutions liave been establislied any sum, at aly time, anil as often which are all becone more or less as wished.

Savings' Banks, allowing interest on S. 'The smallest sun received will deposits. Some have been charter-be a dollar; on which interest will ed, some have not, and two are pri- be given.

vate banks managed by individuals. 4 . Every deposit must be for a Such has been the vitility of this specilic time at the option of the desystem that nearly all the old banks positor: which may be renewed for enjoying a state monopoly have been any other time at pleasure, or withcompelled to mlopt it also. Yet this drawn with in terest at the appointed has not preventel the coinmon kinil time.

of Savings Banks from continuing 5. 'The al or shall receive at its business in the usual way. Aîl his eption a wouk where the sums are thriving and giving good divi- will be entereel, or certificates of dedends.

These Banks have all agrend to ble on demand. ?

give three per cent interest on cass - 6. Livery depositor of $\$ 10$ for al deposits and account currents, five years in his own naine, shall be four per cent on special deposits a sime holder and voter in future payable one month after demand and electiong.

five per cent for those three months 7 . Six per cent slall be given on after demand. 'They also give cer- all deposits, and compound interest tificates of those special demands, calculated after we first year. payable to order. They have there- 8. 'To pay the oxpences of the fore adopted all my views except Institution, one per cont shall be the divisibility of the certificates. deducted from the interion on the - $A$ plan similar to that of Balti- first year, but nothing on any ather more or still further improved, has year, and the odd days of the moith long been contemplated and needed nevel' calculated for the interest.

in Philadelphia; where there are 9. If this fund and the profits of many more savings of industry than the Institution exceed the expences in Baltimore. It is probable that a an extra dividend will be given yearmeeting of the friends of such an ly to those who lave kept the depoundertaking will soon be called, sits one year in the Institution.

meantime a plan is here added of an 10. The Institution shall be maimproved Savings Institution, where-nnaged by a board of - Trustees, in it is contemplated to give six per-electell by the subscribers at the first cent interest for savings; as the meetiug in the first instance; and poor ought to receive as much as the after one year by the share holders. rich for their earnings. Our Savings 11. Each share holder shall be Bank gives only four and a half per entitlecl to one vote ouly, whatever cent which is wrong, and in Newv- be the number of his shares, and he York only five, where the legal in-must vote personally or by letter. terest is seven. Therefore such im- No proxies will be admitted.

proved institution m:st ineet the ap- 12. The 'Trustees must all have probation of all the industrious and deposited at least $S 20$ in the Instiliberal members of the community. tution for five years, and give persoC. $\mathbf{s}$. 1 . 
nal bonds for performing their du-to time, according to the amount of tien.

business fix the compensation to be

13. They shall elect anong them- puill to the I'resident, Cashier, ant selves, a President, a Caslier, and book-keepers, or any other oflicer a Hook-keeper; who must give per- to be employed by the Institution. sonal bonds fur performing their' 19. 'The Institution shall be openduties.
ed at first once a week; but ss soon

14. The President shall presile as convenient twice a week or every at the Bonril of 'I'rustees, and sign day if' requirel, to receive and pay. the certificates, books, \&c.

20. Business and isvestumenis by

13. The Cashiers shall receive the 'I'rustees sliall be trunsacted only and pay the moncys deposited or once a week, unless a special call of withuliawn and keep the securities. the Board, is called by the Presi-

16. The deposits shall be invest- tient.

ed in public or private securities, 21. The Trustees and Officers inurtgages, loans on stock: anil sliall be liable pernonally for their gools; und every other safe business transactions, and the stockholilers ou the divitial plan.

may at any time meet to appoint

17. No compensation slaall be Board of Control, to oversee and given to the 'Trustees the first year. rectify their transactions.

It shall afterwards be decided by 22 . No cliarter of incorporatien the share holderis at tlie first election for this Institution ahall be asked, whether one dollar or more for every uutil it has been two ycars in suctime they ineet, being once a week, cansful operation, and it is demandought to be granted them.

18. The Irusteas shall from timelall the stuckliolders.

\section{LIST ON AGRNTS FOR THIS JOURNAL,} TC \%M BSCRIPTIONS MAY BE PAID.

They are rescisted to send thein in to' us in orders upon Exchange Brokats, or sitis and Drafts. The Names of the Subscribers must not b forgottcis ti we sent speedily.

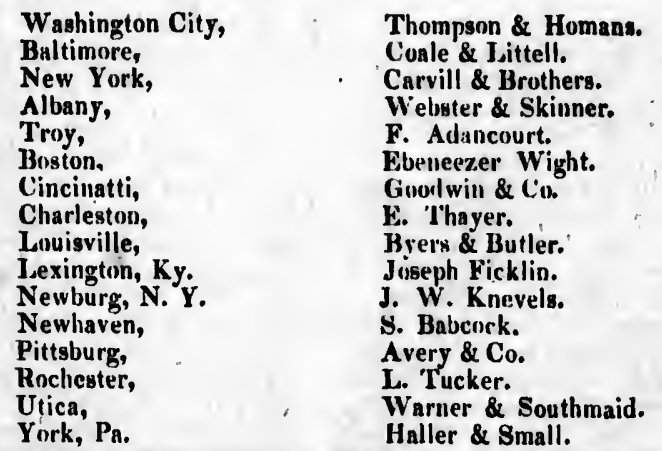

Published at No. 59 North Eighth Street, and at J. Dobson's, No, 108

Chesnut Street, Philadelphia, where Subscriptions are received. 

ensation to be Cashier, and

other oficers

Institution.

shall be open-

s; byt as soon

week or every

ceive and pay.

-vestinents by

runsacted only

special call of

by the Presi-

and Officers

ally for their

gtockholder

at to appoint a overwee and ons.

incorporntien

all be asked,

years in suc-

it is demand-

liree-fourths of

JR.NAR,

AID.

pon Exchange ibers must not

s.

id.

son's, No. 108 received.

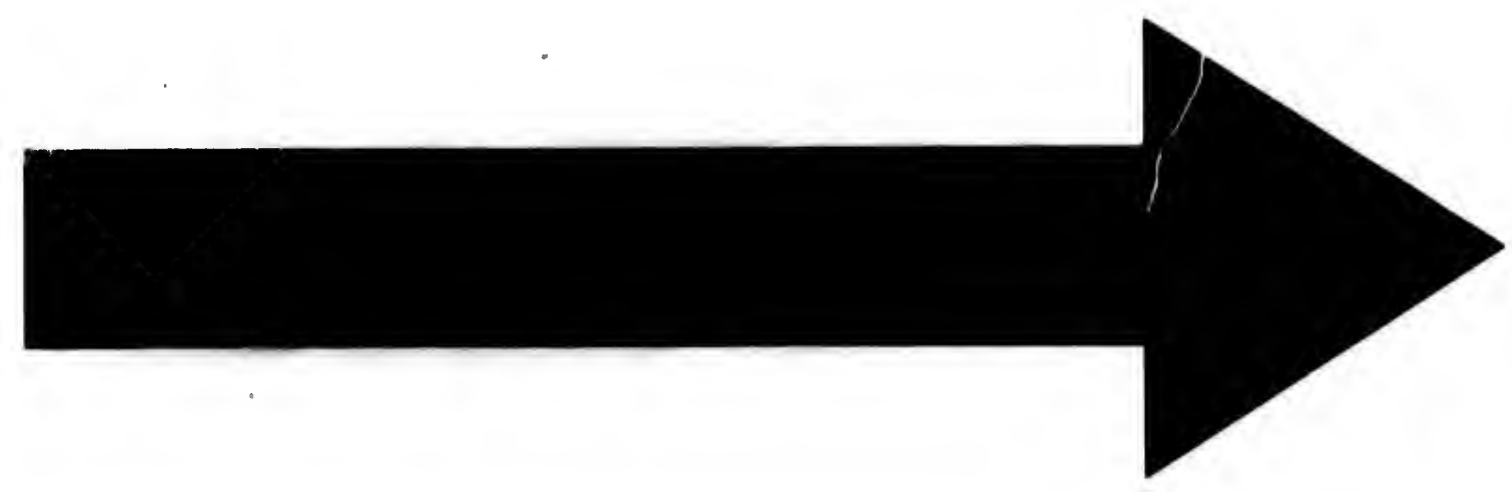




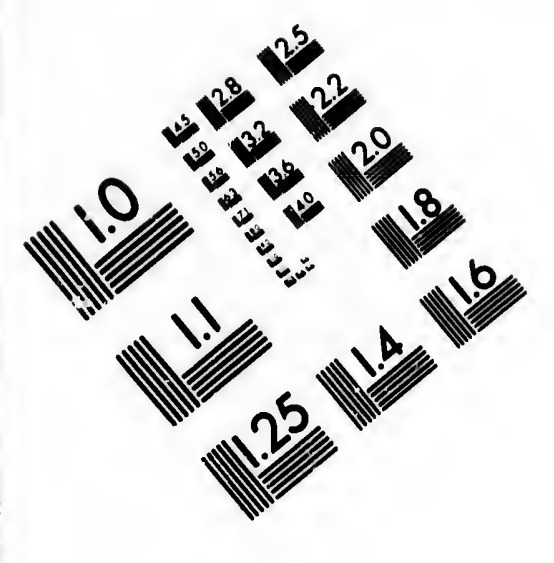

IMAGE EVALUATION
TEST TARGET (MT-3)
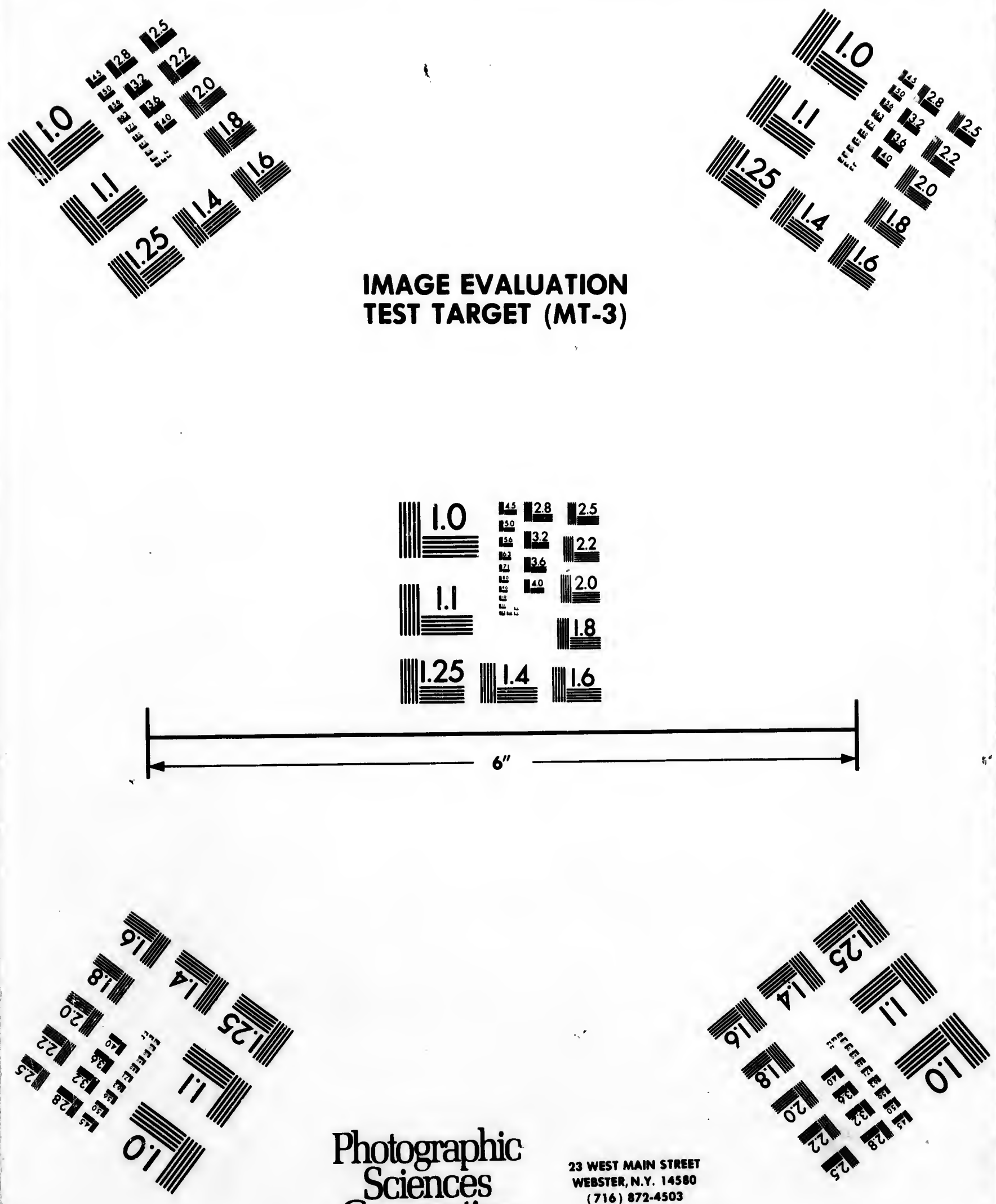

Photographic Sciences Corporation

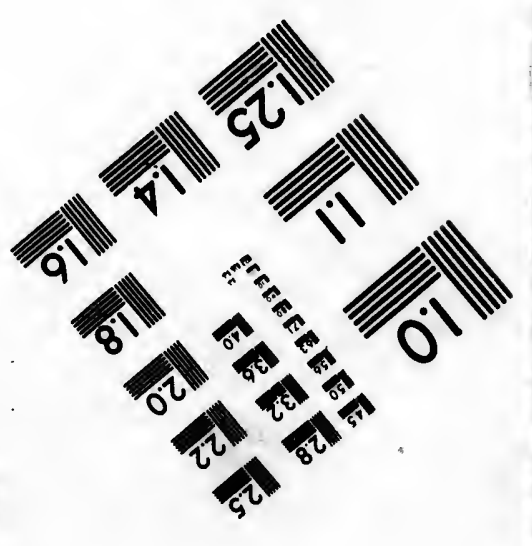




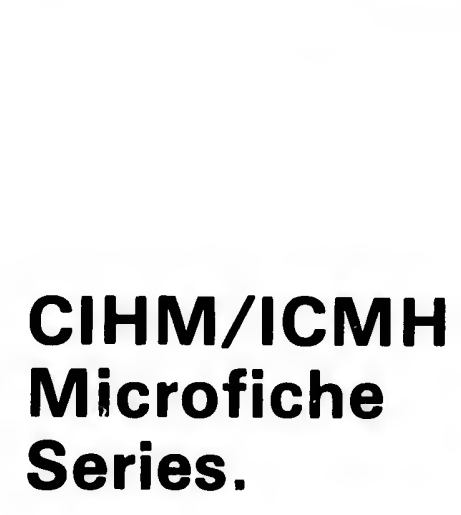

CIHM/ICMH Collection de microfiches.

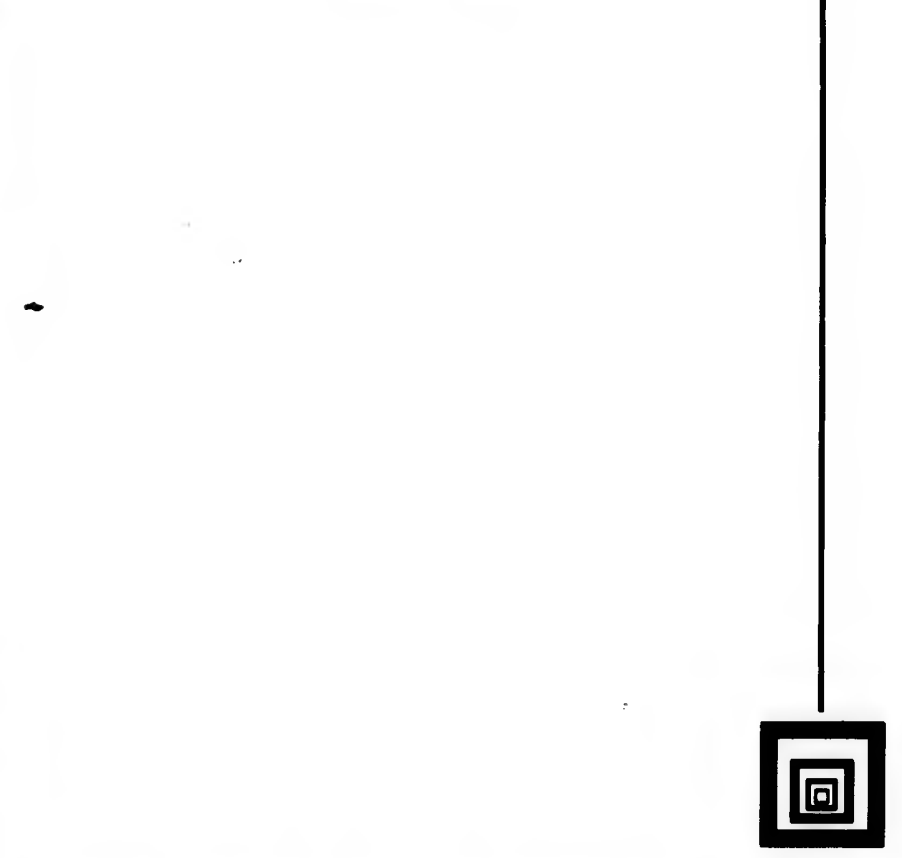

Canadian Institute for Historical Microreproductions / Institut canadien de microreproductions historiques
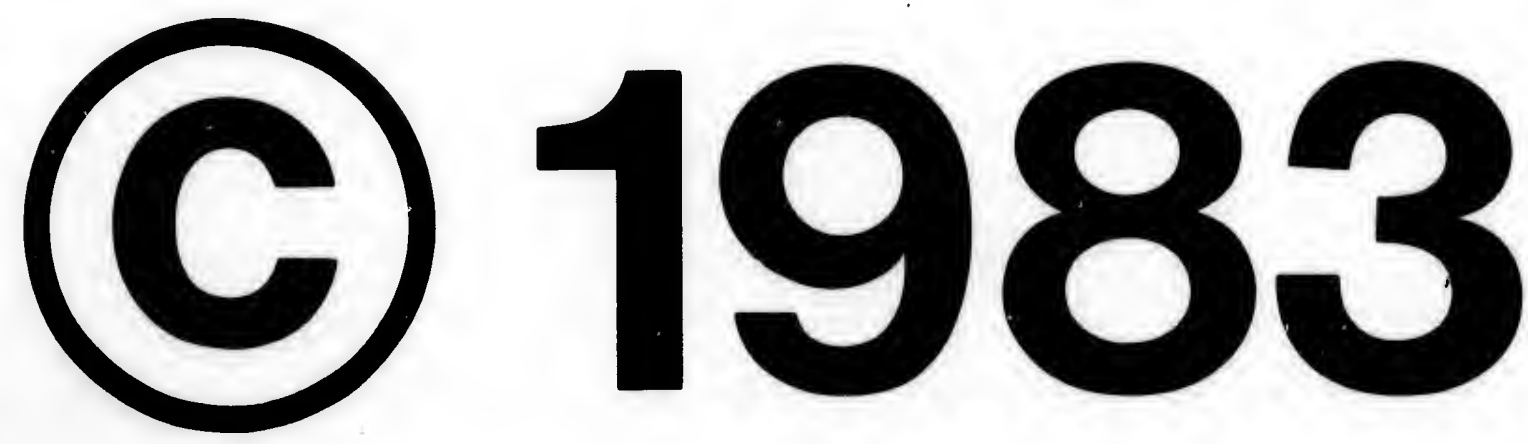


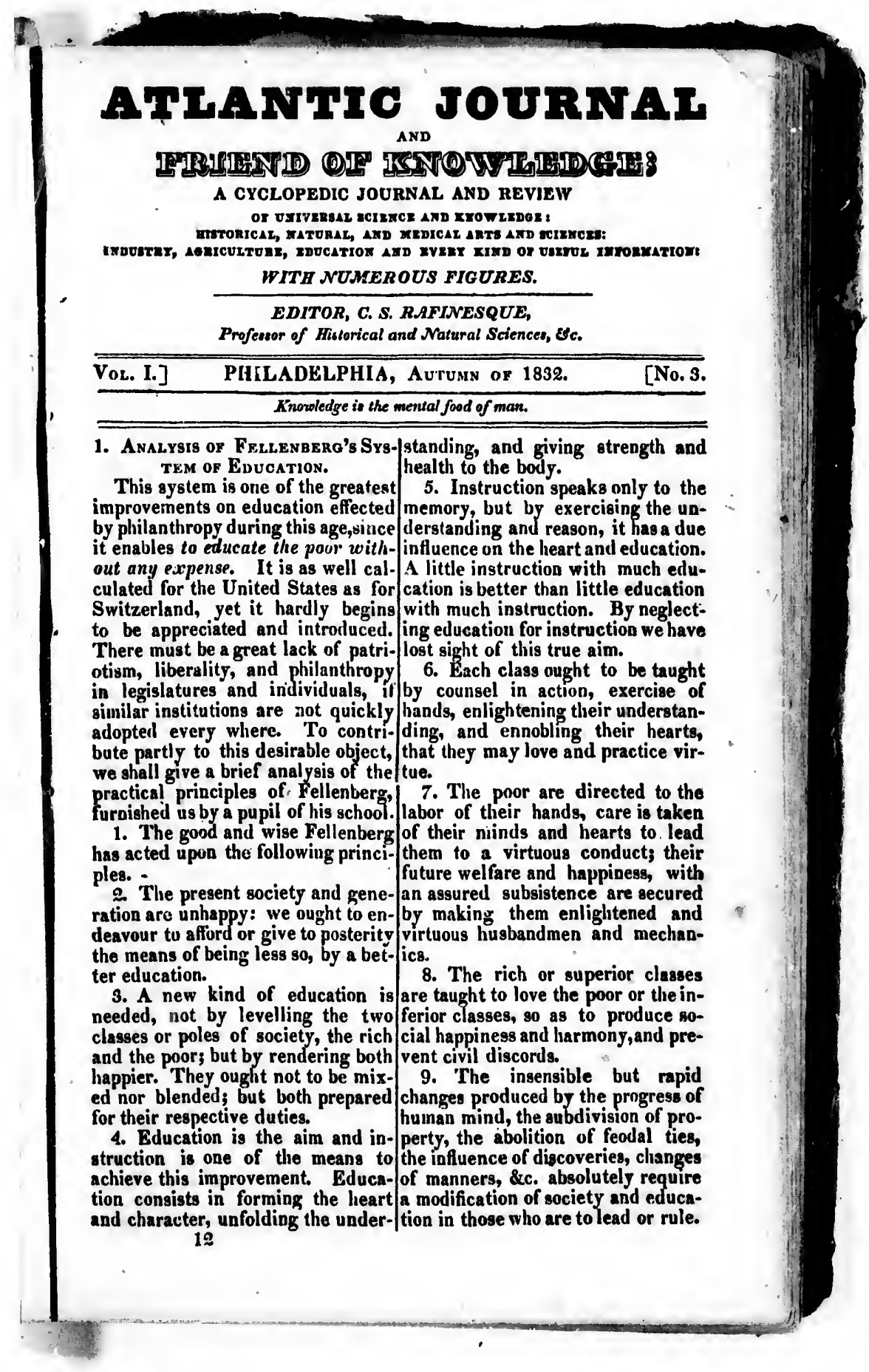




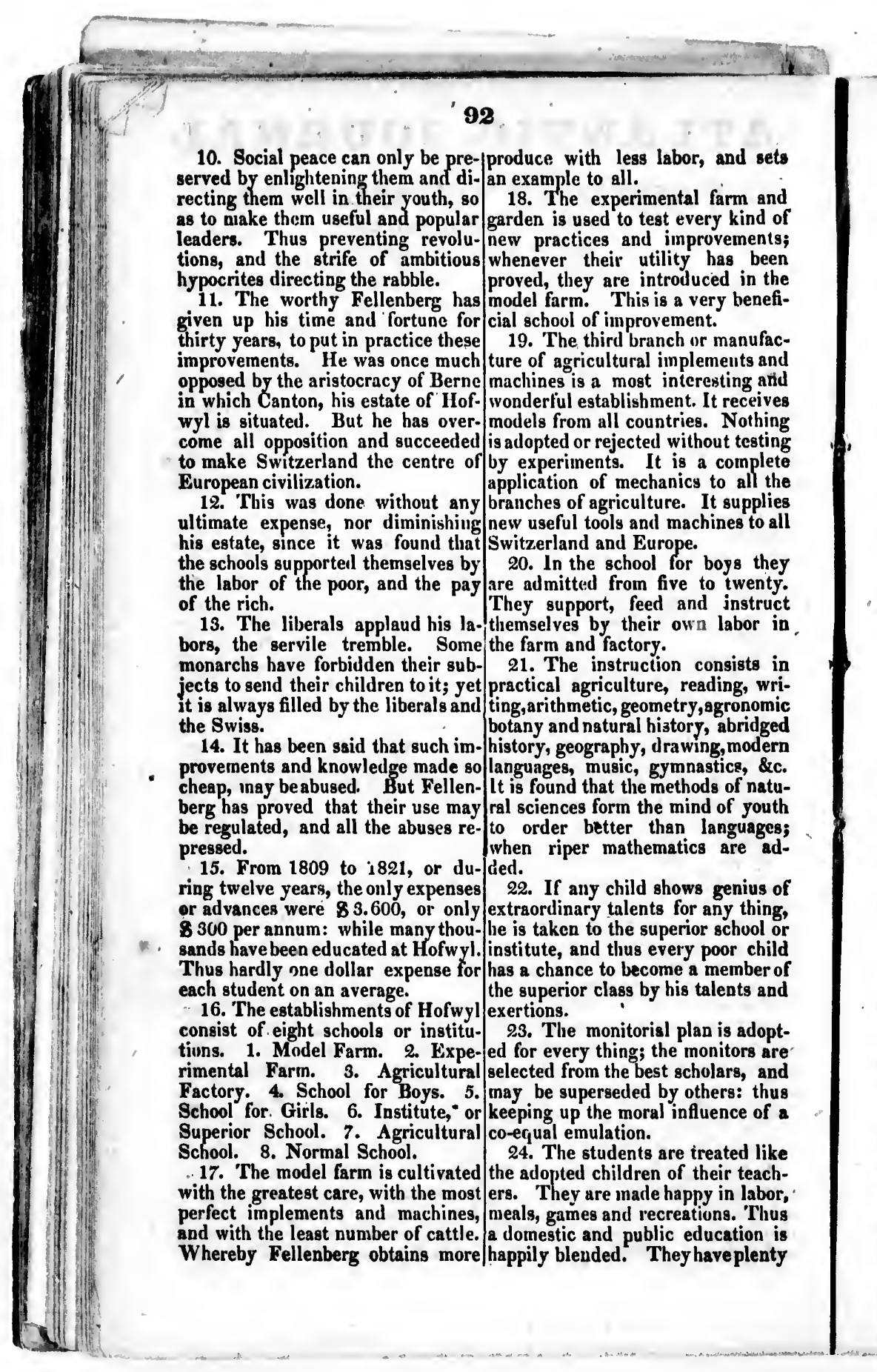


of exercise, a good healthy diet, and/eight to eighteen, will educate at eighteen or twenty they enter the child without cost to the parent nor world well prepared for every duty. the state, and make him a useful en-

25 . The teachers are selected with lightened citizen.

care; , they partake of the labors, studies and recreations, they treat the boys mildly, all punishments are One of the means employed by the lenient and paternal, yet hardly ever foes of knowledge, freedom and ciinflicted.

vilization, to check these blessings,

26. The school for girls is sepa. is to tax knowledge. It is done in rate, but similar. The poor girls many ways in different countries. are raised from the abjection of ser- The most depraved governments vants, taught to provide for them- employ censure of the press, prohiselves. They are employed in sui- bitions, printers' license tax, stamps, table female labor, taught taste and heavy duties on paper and books, skill of hands. 27. The two sexes are not intend- vent tlie circulation of knowledge. ed for the same occupations, women Even in England heavy comhave less strength, but greater skill plaints are made against stamps and in all sedentary occupations. They taxes on knowledge, excessive duare taught all what is required to be- ties, \&c. While in the United come good wives and mothers, which States we appear to follow closely has great influence on producing this example, although we boast of good husbands and good children. complete freedom of the press. This

28. The institute or superior is a kind of political hypocrisy since school, is chiefly intended for the it is not true. Without mentioning rich scholars who pay for their board here the numerous impediments to and tuition; they have somewliat ihe increase of knowledge, exceedbetter accomodations, and are taught ing those of France and England all the branches of science and lite- in some instances, and which shall rature as in colleges: but in other hereafter be enumerated, the actual respects fare and behave as in the needless taxes in knowledge will lower school. now command our attention, and be 29. In the special agricultural exposed.

school are admitted men, all stu- The heavy postages on periodicals dents are above twenty, chiefly land (not newspapers,) on pamphlets, owners, who are taught the improved books, printed circulars, engravings, agriculture of the schools and farms orders, \&c. is the most odious and and pay for it. 30. The last or normal school is obnoxious. Because quite useless,
not required for revenue, nur to aupheld in summer, when forty lectures port the post office department are given to studenis wishing to be When pamphlets were at two cento teachers, to enable them to spread per sheet, it was said that the mails and apply this education to all the were overloaded with them, and that villages of Switzerland.

Let all those who wish for the wel- was triplicated and raised to six fare of mankind and our country, cents per sleet, with the acknowlponder well on this useful, benevo- edged intention of preventing their lent; practical, and practicable plan, circulation by mail, as the tax so as to introduce it speelily with amounts to about two hundred per us everywhere. Few modifications cent on their cost, or one hundred will be needed in the United States, per cent on their usual selling price. we have in fact the two classes of This avowed shameful purpose of rich and poor already, instead of preventing the circulation of pam nobles and poor. Ten years, from/phlets and books, by giving a kind 


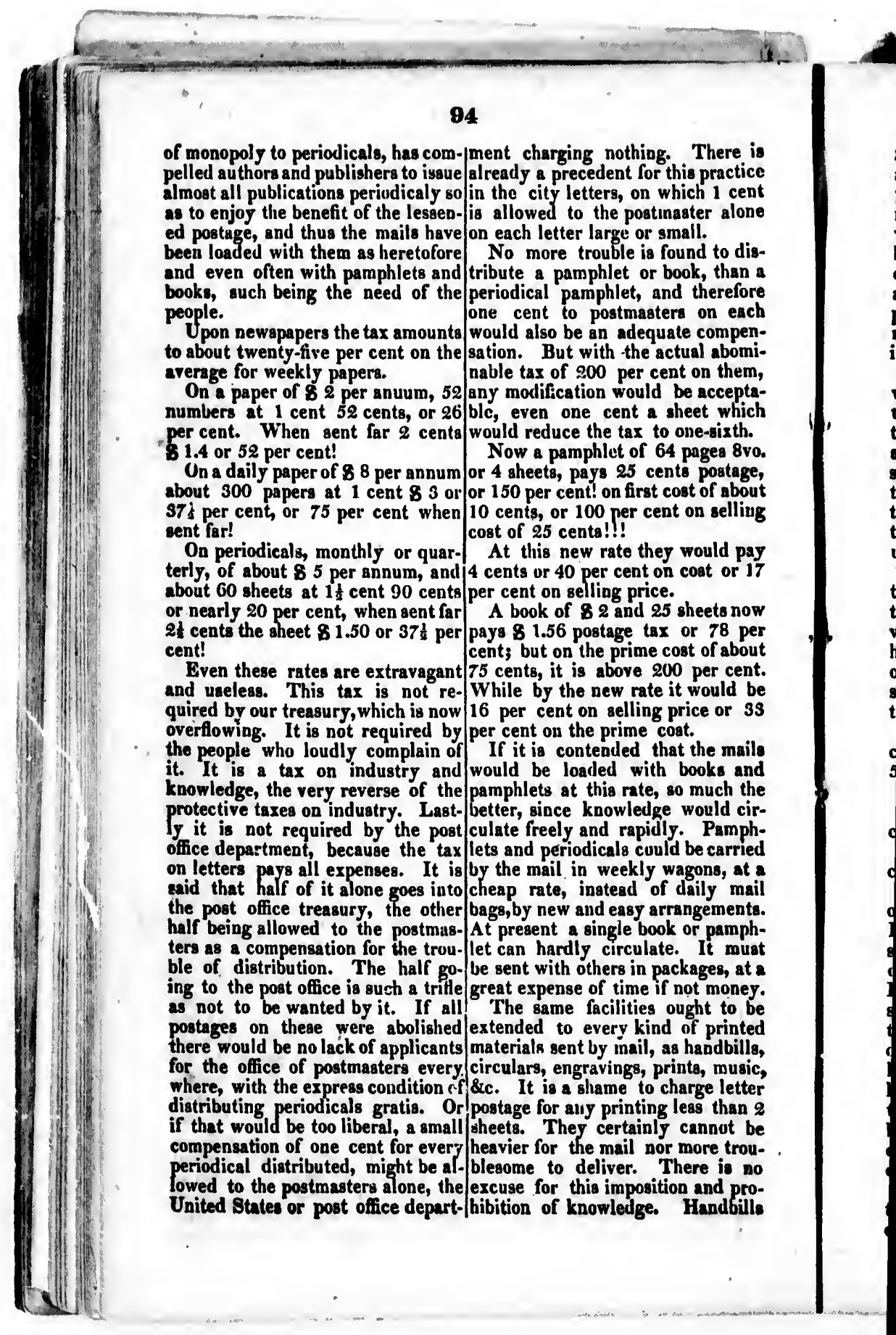


There is this practice which 1 cent master alone small.

found to disbook, than a nd therefore ters on each uate compenactual abomient on them, i be acceptaheet which to one-sixth.

64 pages 8vo. ents postage, c cost of abou ent on selliug

ey would pay on cost or 17 ce.

25 sheets now ax or 78 per e cost of about 200 per cent. te it would be grice or 35 cost.

that the mails th books and 80 much the Ige would ciridly. Pamphould be carried y wagons, at a of daily mail arrangements. ook or pamph. ate. It must packages, at a if not money. $s$ ought to be ind of printed , as handbills, prints, music, 0 charge letter ng less than 2 nly cannot be nor more trouThere is no sition and pro. Handbills
95

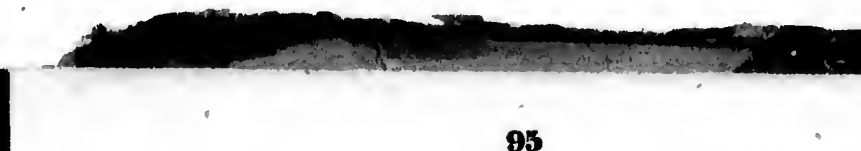

must now be sent by private convey-jes on printera and booksellers must ance or not at all. Circulars are be omitted at present. Let us mereprohibited likewise except to the ly state the fact that there are hearich. 'There is no end to the incon- vy taxes, mostly useless and obnoxveniences to which the public is lia-ious on 1 . Foreign books never printble by these illiberal and pieposter- ed here. 2. On lead and type metal. ous arrangements. A letter of half 3. On paper and inachinery. 4. On sheet pays like a sheet, but half a wood cuts, copper plates, and lithoprinted sheet pays four times as graplic stones. 5. On paper and much as a single printed sheet. Is pasteboard. 6. On skin and parchit not unjust and abominable.

They have probably originated in useful trades and the manufacture want of information in the legisla- of knowledge, journals and books. tors on the subject, and above all in Besides the charges of taxation, adthe fact that they being free of post-vertising, publishing and selling.

age do not feel all the evils of this systen. Let them be taxed too and

they then would perhaps think of 3 . Analysis of the Philosophy of the people they tax, and who pay Pythagoros as promulgated them to make good laws, neither 2400 years ago.

useless nor vexatious. Gon is One: He is within the

Another abominable and useless universe and the universe is within tax is that on double letters, or ra-GoD.

ther inclosures of drafts or money, Gop is every where and yet no whereby the rich can afford to send where! He is a circle, the centre of his large remittances, and the poor, which is every where and circumfeor whoever wants to send or receive rence no where.

small remittances, is prohibited by Gon is the soul of the universe: the following shameful taxes. the order and harmony through

To send a draft or bill or 81 in. which it exists and is preserved.

cluding the letter 25 per cent, if far Gon is the great Unit: numbers 50 per cent!!! and things emanate from the unit.

To send \& 5, 5 or 10 per cent. Gob is universal, inelable, per-

To send 810 , only $2 \frac{1}{2}$ or 5 per fect, and the principle of every cent.

To send 8100, only $\frac{1}{t}$ or $\frac{1}{2}$ per All what is, exists by number and cent!!!

Aarmony.

'I'his falls heavy on all publishers Harmony rules over numbers and of periodicals and many other trades. procluces order.

It is preposterous and intolerable, Harmony is the invisible sun of since there is no more trouble in the the world.

delivery of letters with inclosures. Beauty, good, virtue and health, It ought to be remedied. All money proceed from harmuny.

sent by mail to be free or liable to a The science of numbers is holy: tax of one per cent only, one cent it is the oniy certain one.

on one dollar, and one dollar on one The science of bodies is less cerhundred. This would be just at tain; they are evanescent and ever least. Or else the franking privilege changing.

to and fro of postmasters ought to Nature is a stream that ever be extended to editore and authors, flows.

or all the useful trades who deal and Nature is what may be seen of depend on small remittences.

These post office impositions, ex- Gov is the soul and life of na. tortione and prohibitions have awell-

ed this statement 10 far that the tax- The material part of nature is

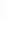




\section{6}

formed by elements: these are the other country but his family and various configurations of its parts. mankincl; he waits for the return of

The souls are particles emanated primitive equality, ere he may adopt from the universal soul.

another.
He tells the truth without fear, it They partake therefore of immor- He tells

tality: their annihilation is impossi- He deplores

ble.

He deplores and unveils the crimes

to another.

of men and uations.

What will be his rewards? perse-

Space is infinite. Time is infinite. cution, contempt or neglect.

GoD is infinite.

If he is asked what Gon he wor-

Nature is incommensurable: the ships, let him anzwer: a God whose

plurality of worlds is evident. bouly is light, and whose soul is

The smallest star is a sun similar 'Truth.

to ours, shining over planets and He believes when he has strong

worlds like ours. motives of credibility, and he obeys

We revolve round the sun; they when he sees the need of it; but not revolve round their suns.

The sun, the stars, the moon, and Let lim respect the law, when it the planets are globes. Our earth is is respectible.

also a glabe.

like on unlike those of inhabitan

The soule travel from bolies tow of universal

bodies, and from worlds to worlds. order and harmony.

This is the spiritual metempsycho- Every man is tacitly bound to presia or passage; the real palingenesy serve this law, and to contribute to or renovation and resurirrection.

Every thing is passage and renovation in nature and man.

the preservation of moral order.

Such is the birth of man, his clild-

The rulers, priests, and warriors, who disturb this order, are as many

hood and his education. Such will The tyrants and slaves sre the be his death.

The tyrants and slaves sre the
hammers and anvils of society. Let

Man will not be annilrilated at us beware to be crushed between this passage, nor die fọrever. $\cdot \cdots$ He them.

will have many lives yet to go Wicked men labor under a menthrough.

Wicked men labor under a men-
Wet us try to cure it.

Rewards and punishiments, await Wisdom is the remedy to be used.

us in these after lives, accoriling to . Let us exercise universal benevoour previous behaviour.

lence. We nust love all men even

GoD is good: men are vicked. When they are wicked.

Why so?

Let us correct the evils of human
nature: by education and instruciniperfect.

to is perfect and ment nat moral evilo and disorders. tion.

Philosophy and wistom correct

these evis and disorders.

'Happiness is 'of
let them reacli'it.'

except to those madmen who seek

Philosophy is not wistom; but it their happiness in the misfortunes of leads to it, it is the love of good. others.

Science is not philosophy; but it ". The regeneration of mankind, leads to it. Science is the knowl will never be conspleted until the edge of order:

insatiable demon of property is abol.

The plilosopher acknowledges no ished. 


\section{7}

But if we were to say to the weal-|mere appearances, nothing is more thy, put your riches in common, deceitful.

they would call us knaves. Let us study their essential and If we were to say so to the igno- real qualities and ficulties.

rant, they might call us louls. If There is ofien no better ground to rulers and powerful imen, they for an opinion than plausibility.

would furbicl us to repeat it. If a thing is pussible, it may be

What is then to be done? Let believed. To believe we must beus labor in silence and by our ex- gin by doubting. Doubt is the manample. A time will come, when it tile of wisdour.

will be safe to speak openly the T'he nature of bodies results from truth.

Real equality will then be uncler- ments.

stood, and effectually established. The elements emanate from Gov.

It consists in every individual be- The sun is the mirror of God.

ing equally enlightened, wealthy and 'T'he light of GoD shines on our

happy, according to his wish and ca. Ininds as the light of the sun on our pability.

eyes.

Natural equality is not fit for the It delights to brighten a good mind. mob nor the ignorant; they could Ignorance is the night of the mind; not enjoy it a single day without errors are its clouds.

mischiet.

But let us work to make them fit mankind.

for it in time.

Our good and bad qualities proqualities pro- happiness.

ceed from our education. Let us reform this essential branch mony of the heavens.

The same order ought to rule over

The reform of mankind is a la-men and socicties, as over worlds bor for ages, it will be subject to and things.

many relapses; but we must not de- Let wisdom unite itself to labor, spair to achieve it. and genius to strength, as the earth

Let nothing disgust us and thwart is united to the skies. us in this noble and eminent under- Nature is a republic. It is inditaking.

Those who feel a passion for the bers thereof act in eternal harmony. love of truth and wisclom will never Nations! you are all the children sink under it.

Let us transmit the means and Men! in all your thoughts and acknowledge from age to age, from na- tions, think of God.

tions to nations. When we wish to become wise Let us nurse with care in our bo- we must not be satisfied with what soms, this last loope of mankind; and is good, but ever strive to reach when its appointed time will come, what is better still.

let us present it to their eyes. This is the complement of wisdom. But let us beware to give guilty Let us improve forever.

bearings to cny eterual truths. But the past has been for us a Meantime let us improve ourselves nixture of good and evil.

and increase our wisdom and knowl- Such will be futurity. Never edge.

Let us beware of our senses, they If we expect every thing, nothing often deceive us.

Our secret senses are our intern- When danger shall threaten us, al sight and feeling. let us warn them by the brazen We must not judge of things by shield of wislom. 
If the promulgation of truth be- Let us beware of blood, money, comes dangerous, let us conceal it and error.

in our bosoms and those of our fel.

low friends.

Let us live and let us die, for

Let us in

truth, justice, equality, benevolence prescrvation of this sacred tire.

Let us become the vestals of truth,

let us preserve this holy deposit pure and unsdulterated.

Benu. Frankuin, Junk.

It is deplorable to conceal truth and happiness from

is olten needful.

AmERioan Nations AND

4. The Amerioan Nations
Triaks are not Jews.

gearly as 1829, I published in

When the time will come for un- but absurd opinion that the Ameri-

veiling the sun of eternal light it can tribes descend from the Hewill be our duty to do it.

brews or the ten lust tribes. This

Let us select with care the restals opinion based upon some religious of truth: every one is not worthy to prejudices and slight acquaintance nurse it.

Our bonds shall be union and harwith philology and sntiquities, has mony, order and knowledge; the rebeen entertained by Penn, Adair, sults wisdom and love, liealth and ficial writers, among which Ira Hill, wealth, happiness and peace.

We must unite the labor of the author of a late work, Antiquities hands to the labor of the mind.

of America Explained. Hagers.

We shall receive no salary for ad- me astonishing how in this enlightmission, nor instruction, nor under ened age, any such unfounded beany other shape; let us beware of ve- lief can be sustained; if grester abnality; must we pay to see the sun? surdities still did not prevail as yet But no one among us can hold among a few.

perpetual property; he may give it 'Two recent instances of egregito whom he pleases. ous folly based upon this singular

We shall live in common with tenet, have induced me to republish our families: our eldest men shall my letter of 1829 , which if read by be our rulers: nur wisest men our those laboring under this delusion teschers and advisers.

Our motto shall be, To do Good cannot fail to shake their belief. Il be, To do Good A new Religion or sect has been and Keep the T'ruth.

Let us be physicians of the body monites, thus called after a new and the soul.

Let us instruct, admonish, and is not a Jewish name.) Supposed Alcoran, or Book of Mormon, (which judge mankind. to be written in gold letters more Let us seek to become mediators than 2000 years ago by Mormon in domestic discords and even in leader of the American Jews. 'This public ones if we are able and call- Book which no one has seen nor ed upon.

Let us guide youth, inexperience, read but the founder of the sect, ignorance, and repentance. the probable writer thereof, has

And let us perform all this with. I have tried in vain to procure a out reivard. copy of the translation, wherein I

Let us pardon, ever before hand, could certainly detect a crowd of those who may do us some injuries, absurdities and incongruities. Meanas we pardon the staff of the blind-time a Sect of Fanatics has arisen man striking at random.

Let us remember that we must York to Ohio and Missouri: an evinot say all to all. 


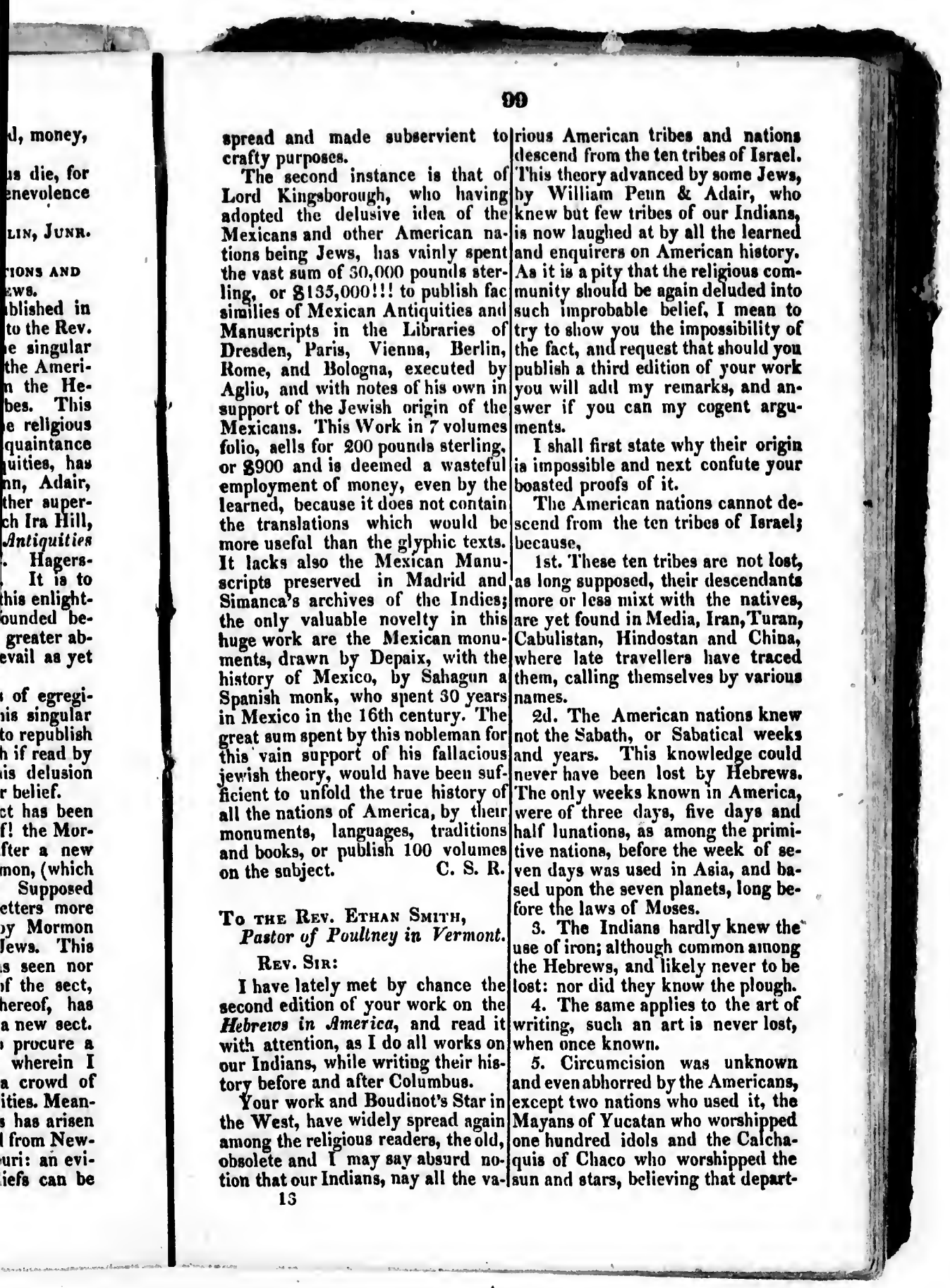




\section{0}

ed soùls became stars. These be-pmost civilized nations. All the anliefs are quite different from Juda- cient religions were found in Ameriism, and hesides this rite was com- ca, 'Tlıeisin, Sabeism, Magism, Hin. mon to Egypt, Ethiopia, Edom, duism, Sliamanism, Fetichism, \&c. Colchis, \&cc.

6. None of the American tribes but no Judaism! have the striking sharp Jewish features, and physical conformation.

uftinities with the Hebrew language, 7. The Americans eat hogs, hares, raib languages. I could show you fish, and all the forbidden animals ten times as many in the Aruac, of Moses; but each tribe abstain Guarani, \&c. but what is that, conlfrom their tutelar animals, or badges pared witl the 100.000 affinities

of families of some peculiar sort, as with the primitive languages.

we abstain from the $l o g$ and horse without any rational cause.

3. All the civilized American had a priesthood or priestly caste, and of so had the Hindus, Egyptians, Percalping, torturing prisoners, cani-sians, Celts, Ethiopians! were they balism, calumet, painting bodies, all Jews? and going naked even in very cold 4. 'Tribes are found among all the climates, are totally unlike the Hebrew customs.

Celts, Negroes, \&c. who are not 9. $A$ multitude of languages ex- Jews. The most civilized nations ist in America, which may perhaps had castes inatead of tribes in Amebe reduced to twenty-five radical rica as well as Erypt and India: the languages and two thousand dialects Mexicans, Mayans, Muhizcas, Peand sub-dialects. But they arc of-luvians, \&c. had no tribes. The ten unlike the Hebrew in roota, animals badges of tribes are found words and grainmar: they have by among Negrocs and Tartars as well far more analogies with the Sanscrit, as our Indians.

Celtic, Bask, Pelagian, Berber, Ly- 5. Arks of covenant and cities of bian, Egyptian, Persian, 'Turan, \&c. refuge are not peculiar to the Jews; or in fact all the prinitive languages many Asiatic nations had them, also of mankind.

the Forntians, and nine-tenthe of

10. 'The Americans cannot have our American tribes have none at sprung from a single nation, because all, or have only holy bags, sumeindependently of the languages, what like Talismans or Fetiches.

their features and complexions are 6 . 'The religious cry of Aleluyah as various as in Africa and Asia._- is not Jewish, but primitive, and We find in America; white, tawny, found among the Hindus, Arabs, brown, yellow, olive, copper, and Greeks, Saxons, Celts, Lybiana, \&c. even black nations as in Africa. Al-under the modification of hulili, 80 dwarfs and oiants, handsome and yululu, luluyah, \&c. other Ameriugly features, flat and aquiline noses, cans called it ululaez, gualulu, aluthick and thin lips, \&c. yuh, \&c.

Let us now examine your proofs. 7 . The mentioned traditions of 1. You say all the Americans had our Indians or rather the Algonquin the same god, Yohewah: this is ut- stock only, point to a N.W. origine; terly false. This was the god of the but the Natchez, Apalachians, TaChactas and Floridans. I have found lascas, Mexicans, Mayans, Muhiza multitude of names for it among cas, Haytians, \&c. have traditions the Unitarians. Many had triple to have come from the East or through gode or trimurtis as in Hindostan the Atlantic Ocean. It is important and with names nearly Sanscrit. to distinguish the American nations Polytheism, idolatry and a complex of Eastern origine from tho later inmythology prevailed among all thelvaders from Tartary: they are as 


\section{1}

All the andin Ameriagiam, Hincliism, \&c.

you give of w language, lan and Ca. d show you the Aruac, is that, com00 affinities rages.

merican had y caste, and yptians, Per-

s! were they

among all the bs, Berbers, who are not lized nations ribes in Amend India: the Muhizcas, Petribes. The bes are found artara as well

$t$ and cities of to the Jews; had them, also nine-tentha of have none at y bags, someir Fetiches. of Aleluyah rimitive, and indus, Arabs, , Lybians, \&c. on of hulili, other Amerigualulu, alutraditions of the Algonquin N. W. origine; alachians, Taayans, Muhizave traditions East or through It is important ierican nations $m$ the later in. I: they are as difierent as the Romana and Van-psent now to this evident historical dals.

fact, see Wells, Russell, \&c. as well

8. All the alledred customs com- as all the philosophers who are not mon to Jews and Ainericans, are blinded by their systems.

positively of primitive origine and Bishop Heber las said that the found also among nearly all the an. Inalaya mountains were the centre, cient nations of Asia, Africa, Eu- the cradle, the throne, and the altar rope and l'olynesia, nay even ainong of the earth. 'Therefore they wero the wild negros to this day; are they the cradle of inankiud, from whence then all Jews! The actual Puritans the variuus nations have spread like and Sabatarians who keep the Jew- divergent rays throurhout the surish Sabath and bear. Jewish names, rounding lands and isfands.

would be grenter Jews by far, if cus. 'The mountains and tablelands of toms alone were to settle this ques- Central $A$ sia, deserve therefore the tion.

utmost attention from us in every

You will therefore perceive that point of view, either religious, or this old notion of yours is totally in- historical, or geographical. Yet we possible and at variance with all our lo not know them completely: the knowledge of the Ainericans, when Southern slopes and sides with the we atudy all the Nations, instead of centre alone have been lately extaking as you do the Algonquin or plored, while the Eastern, Northern Lenapian although a widely spread and Western sides have hardly been family for your rule and inain exam- penetrated. However we know ple of all.

I hope you will consider again the clusions, and travellers are now atquestion with impartiality, divesting tempting their further exploration. it of your mystical problems, and Those who have already visited and studying the writers on South Ainer. described these interesting mounica with more care. You will find tains are chiefly Polo, Gruber, Goez, that Garcia a Spanish writer, had IVebb, Moorcroft, Turner, Frazer, 200 years ago, in his origin of the Herbert, Gerard, Jaqueminot, BuIndians provel that they may have chanan, Kirkpatrick, \&c.

come from many ancient Nations, Many names have been given to even before the flood, and Dr. $\mathbf{M}^{\prime}$ these central lofty regions of Asia, Culloh of Baltimore, has proved the that furnish important references.

same thing in wis researclies on Ame- Ina-loya the actual Hindu name rica. C. S. R Ariwesque means Snowy or Icy mountaing. Phadelphia August 1829. The Muz tag of the Tartars has the same meaning; 2000 years ago the 5. The Cradie of Mankind or the Gieeks called them also Iniaus.

Imalaya Mountains. This name is chiefly given to the

The learned liad long disputed on Southern range which the Chinese the locality and habitation of the ulso call Sien-shan or snow mounprimitive progenitors of mankind. tains. But every range and side has Those who believed in a single cra-peculiar names. Three principal dle as Eden sought for it in various ranges appear to run from E. to W. parts of Asia.-Others believing of which the Imalaya or Southern is through pride or ignorance in many the longest since it is connected with ouch cradles found them almost the mountains of Persia and Caucaevery where or in all the continents. sus to the West, and those of China Both were wrong; late uncontrover- in the East.

tible discoveries and proofs have The others are the Lung-shan proved that the cradle of mankind (Dragon Mts) or the Tien-shan (Cewas unique and in the central moun- lestial Mts) of the Chinese, and the tains of Asia. The best biblists as- Altay of the Tartars the most Nor- 


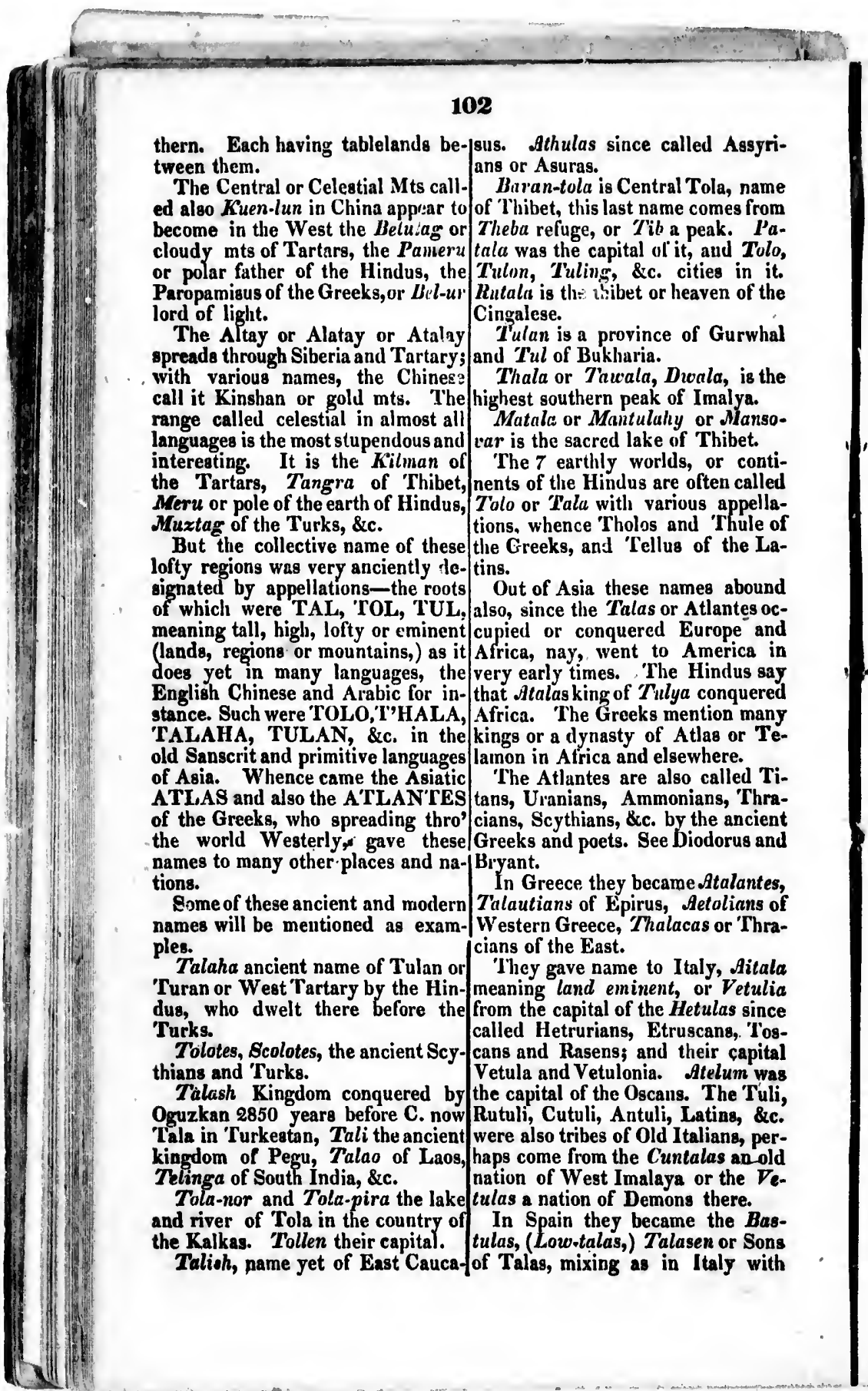




\section{3}

led Assyri-

Tola, name comes from peak. $P a$ and Tolo, ities in it. eaven of the

of Gurwhal roala, is the Imalya. or Mansof Thibet.

s, or contioften called ous appelland Thule of 3 of the La-

mes abound Atlantes ocEurope and America in Hindus say a conquered ention many Atlas or Teiewhere.

so called Tinians, Thra$y$ the ancient y the ancient
biodorus and

me Atalantes, Aetolians of acas or 'Thra-

Italy, Aitala o' Vetulia Hetulas since uscans, 'Tostheir capital Atelum was 18. The 'Tuli, Latins, \&c. Italians, perntalas an old a or the $\mathrm{Ve}$ ne there.

me the Baslasen or Sons n Italy with the Oscans or Baskans or Eskaras, 2. The origine of nearly all the dosince Cantabrians. In Europe a multitude of cities, and fruits being traced there, where rivers and districts bear their names they are founcl wild to this dlay, and from Toledo in Spain to 'Tula in hardly any where else. Russia.
Northern Africa is filled with their are the highest on earth, although Russia.
Northern Africa is filled with their are the lighest on earth, although remembrance and posterity. The the Andes of America reach very Western mts called Atlas by the near to the same height; but these Greeks, were formerly called $A d$ - are volcanic, thus unifit for a very tala or first highland, now Adla and carly life population \& civilization: Tedla. Hanteta (whence Anteus) while the Imalaya are primitive and Adala, Altara, Atys, \&c. were parts fruitful. The highest ints must of of it. Tella are yet the $\mathrm{mts}$ of $\Lambda \mathrm{l}$ - course have been the first to appear giers. Ptolemy calls the central mts above the waters of the ocean; they of Africa Thalas, and the Eastern were not then covered with eternal are Tagla. 'Those of Fezzan are snow as now, being low above the the Gontela. $\quad$ waves. Their table lands are the

Besides the true Atlantes of Afri- loftiest and largest on earth; thus ca which were said to have come likely to be the first habitation of from the Caucasus, we find there the men and animals.

Autololes, Thalas, Taludas, or $\mathrm{Da}$ - The African Atlas has been deemradas, (now Torvdos,) Getulians, ed by Jackson in 1820 to be higher Teladusi, \&c. all tribes of Atlantes; than Imalaya, because it is seen 245 besides the Atarantes, called also miles off, in latitude 82 , which he esHamantes and Garamantes. Many timates to indicate a height of 29610 cities bear their names, one of the feet; and the Mountains of Elala in oldest is Talata in the Messalata Suz lat. 30 seen at 240 miles to be hills of I.ybia neal Tripoli where is 28980 feet above the sea. But other a huge mound or altar $\mathbf{3 4 0}$ feet high travellers lessen one half or one now Zetiten.

These African and Spanish Atlan-be from 14500 to 18000 feet: we have tes gave their name to the Atlantic however no correct mensuration of Ocean and to the great Atlantis or it, and it may probably be found America! called in the Hindu books nearer than supposed to the Imalaya Atala or Tala-tolo the fourth world height. Like the Andes of South where dwelt giants or powerful America; Chimborazo 21425 feet men. America is also filled with their but lately Sorata has been found to names and deeds from Mcxico and be 25250 .

Carolina to Peru, The Tol-tecas Although the different travellers people of 'Tol, and Aztlan, Otolum who have measured the peaks of Imanear Palenque, many towns of Tula laya differ somewhat, yet they all and Toiu. The Talas of Michua- agree within a trifle, and in stating can, the Matalans, Atalans, Tulu-that the valleys, plains and table lcis, \&c. of North America, \&c. lands between them support vegeta-

Thus all the Western Nations tion and cultivation at a higher level trace their cradle to the East and than any other country.

Central Asia: while the Chinese Dhawala or Tawala (Hoary) is said trace it there also, as well as the to be the hinchest properly measured, Hindus of the South and the Tartars it is in lat. 19. Webb found it 27550 of the North.

Besides these traditional proofs, than 27000 . But Chumelari has two others concur to prove this fact. been estimated at 30,000 feet. While 1. The height of these mountains.|the Celestial Mountains and Muz- 


\section{4}

tag are believed to exceed 32000 fe et, lever all stratifled even to the highest although they have not yet been/peaks. The strata are commonly reached nor measured. But they are inclined 40 to $45 \mathrm{deg}$. but often perseen at the distance of neariy 300 pendicular, and some jumbled in all miles. kinds of direction and forms, so as

The linits of perpetual snow in to resemble marble paper! They are lat. 32 is not at 11000 feet as syste- coinmonly of Quartz,(black or white) matic calculation would have it, but Hornstone, Granite, Gneis, and at 13500 feet. Frazer found vegeta- Micaslate. Gangotri is entirely gration as far as 13192 feet, Mosses and uitic, Jumnotri has veins of all coLichens as far as 14700 feet. Against lors. Sce Frazer.

all rules the Northern side or slupe of No Volcanoes are found in ImaImalaya is warmer than the South-laya, except lake and water volcaern, owing to dryness and latent noes; Tirtaputi in Ladak is a hot heat. Gerard and Jaqueminot found spring like a volcanoe spouting sediin Thibet cultivation as far as $\mathbf{1 7 0 0 0}$ ments half a mile in circuit. Some feet, and perpetual suow only at burning volcanocs in the Altay have 20500 feet! Therefore the cliinate not yet been visited. No diluvium and soil improves inland in these is found on the mountains and peaks lofty regions, and were still milder of Imalaya, except in some valleye, once when the peaks had no perpetu- where inar.y eruptions and disrupal snow. tions of lakes have taken place.

Thibet lies between the Imilaya They have fossil remains in the seand Ceiestial Mountains, Tortary condary strata; but hardly any dibetween these and the Golden ?oun- luvial fossils. It is therefore doubttains or Altay. Both are lot plains ful whether the geological floods and table lands from 10000 vu 15000 reached that lofty land, and probafeet above the sen, fertile and popu-ble it was the THFBA of the Bible lous, except in the sandy desert of or refuge in Noah's flood.

Cobi. Imalaya and its branches $\mathbf{E}$. and

North of Casimir the Inalaya $W$. are the true native country of Mountains take the name of Vind- the Wild Ox, Horse, Ass, Goat, hyan, West of the Indus they be- Sheep, Hog, Doo, Cat, Camel, Hen, come the Hinducush meaning Dark Duck, Plieasant, \&c, and alınost Mountains, with peaks 20500 feet every other animal that las since high. Three ranges of ridges form been clomesticatel, except those pethe Imalaya proper, with peaks from culiar to America: the Yak or Thi21000 to 28000 feet ligh. "The third bet Cow is peculiar to it, and has ridge is not pentrated by the rivers, not yet been spread very far.

the Indus and Ganges penetrate the All our fruit trees, all our cereal two others.

The Geology of these Mountains plants are also found growing wild is very interesting. As you ascend in those mountains. It iwas long a them four ranges of secondary hills problem whence came our Wheat, and mountains are found on their Barley, Maize, Rice, \&c.; but they Southern slopes. 'The first from 500 have lately been found there by trato 750 feet above the plains of India vellers. They all say that there, is is of Sandstone, clay and gravel. found the climate with the producThe second is of Claystone from tions of Europe. They enumerate 1500 to 5000 feet high. The third/among the wild trees and fruits, the are mountains of Limestone 7000 Apples, Pears, Grapes, Plumbs, feet high. And the fourth of slate Peaches, Apricots, Raspberries, $\mathbf{8 0 0 0}$ feet high. See Frazer. Strawberries, Currants, Chesnuts, Beyond begin the three primitive Walnuts, Mulberries, Gooseberries, ranges of Imalaya, which are hou--Almonds, Cherries, \&c. \&c. also, 


\section{5}

highest

mmonly ften pered in all is, so as They are or white is, and rely gra$f$ al $c 0$

in Imaer volca-

is a hot ting sedit. Some ltay have diluvium and peaks e valleys, d disrupn place.

in the se$y$ any d:ore doubt-

al floods nd probathe Bible

es E. and country of ss, Goat, nel, Hen Id almost has since those pek or Thi, and has fal. ur cereal : culinary wing wild as long a Wheat, but they re by trathere, is e producnumerate iruits, the Plumbs Plumis Chesnuts, seberries, \&c. also,

\section{Pे}

1 the Roses, Oaks, Pines, Larch, Ce- Ghauts of India, also the Mountains dar, Heath, Birch. Fir, \&c. While of Persia, Dalmatia, \&c.

among the useful plants the follow- 3. Third age, Circular Mountaing ing are both wild or cultivated in va- with concentric Ridges, such as the rious parts, Wheat, Barley, Rye, Western Alps, Mountains of NorRice, Mayze, Cotton, Pease, Beans, way, Brazil, \&:c.

Lentils, Millet, Gourds, Melons, 4. Fourth age, Mountains in diCarrots, Turnips, Cabbage, Onions, vergent groups, such as the Central Fennel, Egg plant, Madder, Clover, Alps, the Balkan, Caucasus, Hina\&c., \&c.

These animals, fruits and plants, 5 . Fith age, the Andes of Amewhich have accompanied mankind in rica.

his migrations, afturd a strong proof 6. Sixth age, Volcanic Mountains, that man first knew them there, the newest.

which was their common cradle, and 'This System, like so many others where began pastoral and agricultu. in Geology, is based on observations ral life. chiefly made in Europe, and the opiMany nther proofs could be addu-nion that Mountains have broken the ced to support this truth: since civi-primitive concentric Strata of the lization, religions, governments, as- earth by rising from below by crystatronomy, the arts and sciences, nay lization or intumescence. Is it not erevery thing valued or employed roneous to suppose that the primitive by men can be traced also by us Imalaya and Caucasus are less anciEasterly to those mountains, or those ent than the Secondary Alleghany \& of Iran and 'Turan on their West Apennines? they appear quite as slope near Persia and Turkestan; inuch disposed in ridges. All Moun. Cashmir and Balk being there two tains except the Volcanic may be of the earliest seats of civilization. considered as huge Crystals; their There also points the Grecian and distinction in four series, SedimenHindus Mythologies, Chinese His- tal, Parallel, Concentric and Divertory, and every primitive tradition; gent, appears correct; but this disnay every language of the earth can position in crystalization may lave be traced to that central cradle. Ween contemporaneous, and does not C. S. RaFinesque. affurd the best clue to their relative 6. OREOLOGY. Relative Are of Mountains. Imalaya and Andes, are the oldest.

Although it is impossible in Geology to ascertain the exact age of Mountains, Strata, and Fossils, yet 8. Georogical Survey of the Al-

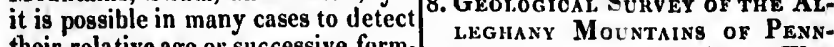
their relative age or successive form. SYLVANIS, in 1818, from West ations.

Beaumont who has lately paid peculiar attention to Mountains, thinks that he has found their relative age, and divides them into six ages or series.

\section{to East.}

By Professor C. S. Rafinesque.

It is well known that the Alleghany Mountains run in parallel ridges from North to South, therefore in

1. Oldest, the undisturbed Sedi-crossing them from East to West mental Mountains, such as those or from West to East, their strucof Saxony, Pilat and Cotedor in ture, and the component strata of France, \&c.

2. Second age, Mountains in pa-certained.

rallel ridges, sucls as the Alleghany, I have crossed or penetrated those Carpathian, Apennines, Pyrenees, Mountains in 20 places from New.

(1)

.




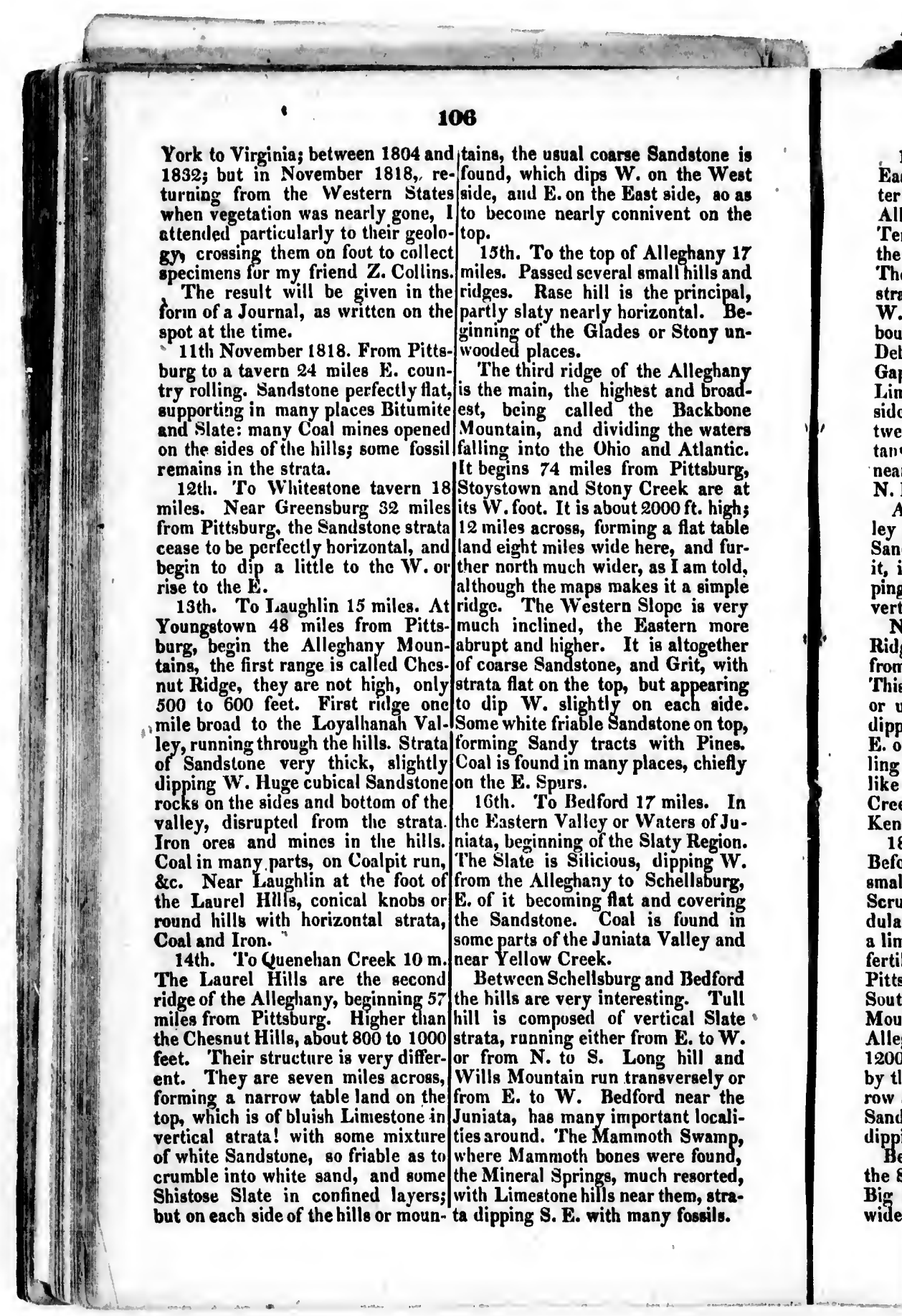




\section{7}

17th. To Licking Creek 25 miles. to the Hudson. The West side of East of Bedford are two narrow Wa- it is Slaty, the centre Limestone, ter Gaps in the fourth ridge of the and the Last side Quartzose, where Alleghany, called the 'Tortoise or begins the Prinitive Region. "These Terrase Mountain, through which three formations extend more or less the Juniata has broken and flows. through the valley, but are alwaye The first is Denning's Gap. The parallel. Here the Schist or Slate strata are of Sandstone, dipping $\mathrm{S}$. extends nearly to Chambersburg. It W. with many huge Limestone is foliated, and nearly vertical, when boulders unrolled but carried by the dipping the small dip is $\mathbf{E}$.

Debacle. The second Gap or 'Iurtle 19th. To top of South Mountains Gap, is of Vertical Sandstone, with 12 miles. Limestone nearly all the Limestone resting on it, or to each way in the valley, about nine miles side in inclined strata; while be-wide. It is a blue or white Limetween the two gaps five miles dis- stone chiefly, with veins of Marble, tant, the whole is Slate or Schist, Lias and white Spar, with a great nearly vertical, and running fiom dip to $\mathbf{E}$. but often nearly vertical N. E. to $s . W$. Along the Juniats and in the val- lose and smooth as if water worn. ley beyond the whole country is of Many sinks in it as usual in LimeSandstone beneatlı and Slate above stone Regions, soune dry, some reit, in various directions, either clip- ceiving streams that sink in it, some ping West, or undulating, or nearly cluanged into large Springs. They vertical. Next comes Sileling hill, the fifth the ancient craters of the limy outRidge of the Alleghany, 104 miles lets. No fossils seen in it.

from Pittsburg and five miles broad. At the foot of the South Moun.

This has quite a regular connivent tains begins the primitive by a coarse or undulating strata of the sane, quartzose rock, with Debris and dipping $W$. on the West Side, and Boulders of primitive rocks. These E. on the East Slope. East of Side- Mountains are here low, not above ling hill, the strata are undulating 500 feet high, but seven or eight like the small hills. On Licking miles broad, with rousded hills. Creek there are Licks like those of The whole has a granitic nucleus as Kentucky, with Clay. 18th. To Chamber 26 miles found in place. It is coverel 'with Before the Cove Valley, are two a con'se Quartzose rock resembling small ridges called Great and Little Sandstone, and the whole track has Scrub ridges, chiefly slaty and un- many diluvial Debris and Boulders dulating. The fine Cove Valley has of Granite, Quartz, Iimestone and a limestone and alluvial bottom very a curious Pudding Stone, blue with fertile. East of it, 127 miles from white oblong spots. Iron is found in Pittsburg is the Cove Mountain, a many places. Some boulders are Southern branch of the Tuscarora rolled ar worn, others are not. Mountain, and the sixth Ridre of the These Mountains improperly called Alleghany on this roacl. It is about South Mountains, are the Matta1200 feet high and five iniles across wan Mountains of the Indians, and by the winding roal, although nar- the lighest primitive ridge bordering row at the top. The whole coarse the Atlautic prinitive formations Sandstone in thick strata, slightly extendiug E. to the Schuylkill river dipping, or undulating over it. at l'hiladelphia, in wide plains with Between the Cove Mountain and low hills. The whole breadth of the the South Mountains to the E. is the Alleghanies near lat. 40, is therefore Big or Long Valley, liere 23 miles about 115 miles. wide, which extends from Virginial 20 th. 'To Gettys'surg 12 miles. 


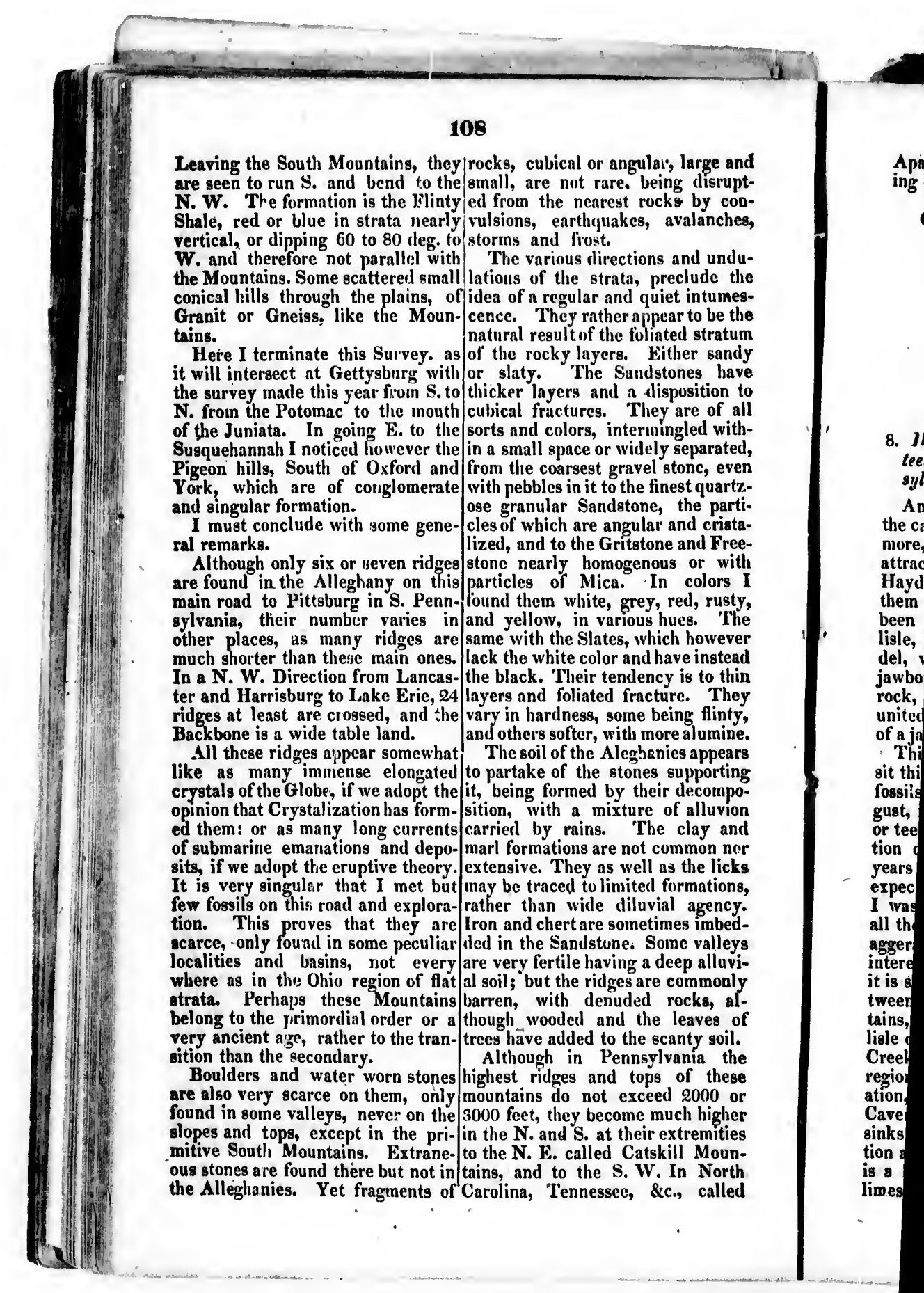




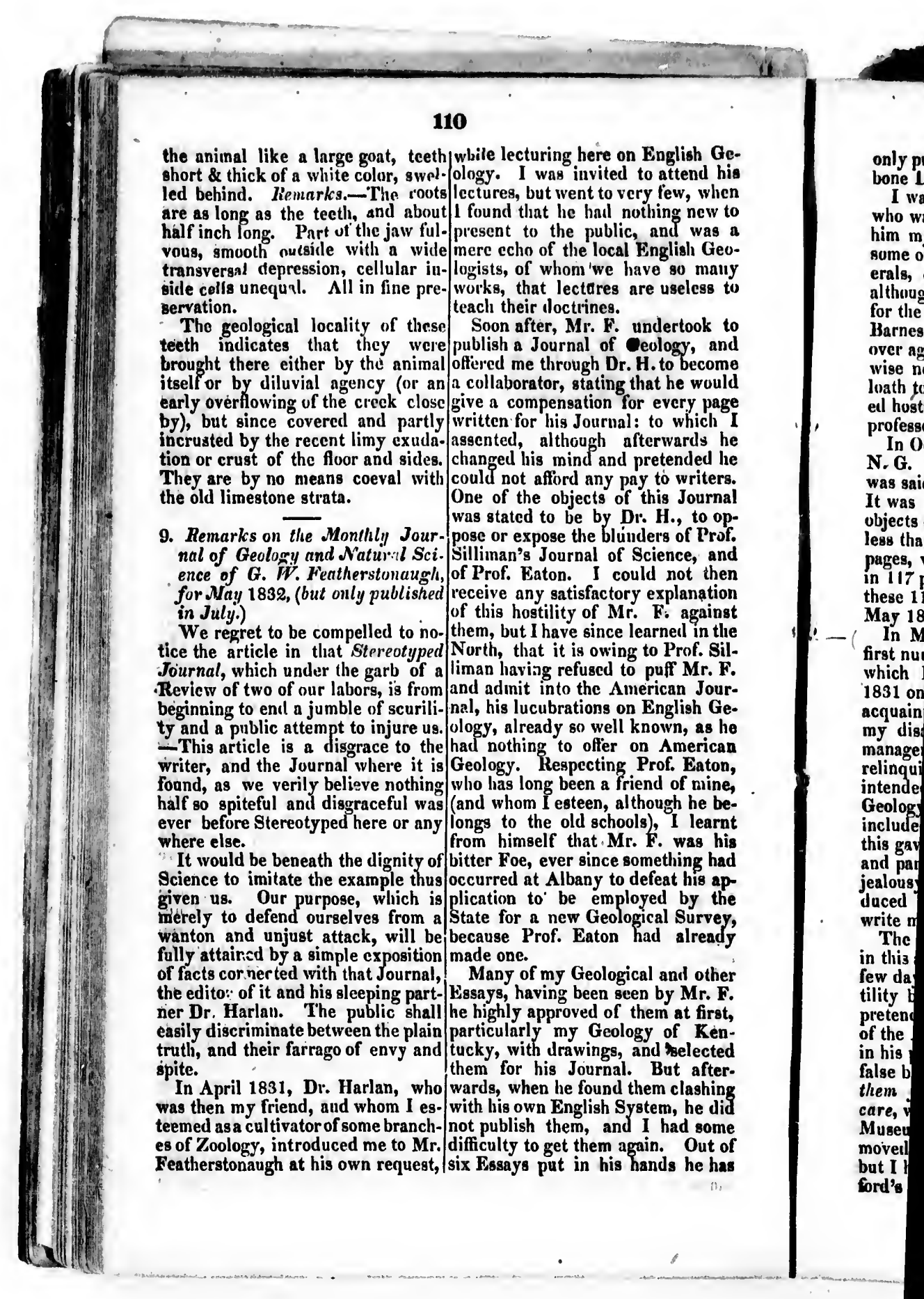




\section{1}

only published one, my Visit to Big- labels many were erroneous, as they bone Lick.

I was often urgel by Dr. ILarlan, Museum now in the Academy of who was the agent for Mr. F. to give Natural Sciences of Pliladel phia, him my remarks and criticisms on where some European fossils are some of Silliman's and Eaton's min- inixed with American, to feed future erals, \&c. but I delayed to do it, geological blumlers, and my beaualthough I conld have no partiality tiful N. G. T'rianisitrs of 1818 , is for the first, who has allowed Mr. called Tyraniles! When Dr. H. Barnes to publish my Ohio Shells, showed we again the bones, iny meover arain in his pares, and other- mory was not bent upon that subwise neglected my labors. I was ject, yet I told him that I had calloath to become an ally in the avow- led thein. Hula.rodum, from the sulel hostility against those respectable cate teetlı: but not published them professors. In October 1831, I published my published first these fossil remaius N. G. Trinectes, on which nothing as a new Megaonyx, and I gave him was said by Dr. H. till March 1832. |credit for it. While he has not done It was in iny enumeration of some the same when he published my objects of my cabinet, containing not Necturus under a new name, as well less than 117 new objects in eight as other auimals, which I overlookpages, while Mr. F. has about eight ed on the score of his personal in 117 pages of his Journal. Out of friendship. It is not true that $I$ have these 117 only six are criticised in abolished the G. Megalonyx of JefMay 1832. ferson, which is a different animal. In March 1832, I published the 2 dly. As to the fish called by me first number of my Atlantic Journal, Trinectes in Oct. 18s1, it is true that which I had announced in March the first specimen was given me by 1831 one year previous, befure I was Dr. H. who could make nothing of acquainted with Mr. F. and which it, and called it a Flounder; but he my disappointment in his editorial gave me the specimen to describe, management did not induce me to name, figure and keep, I had then a relinquish. This journal was not right to send it to Cuvier, which I intended to clash with his; but as did to have his opinion on the stri. Geology and Natural Science were king want of anterior fins, making it included in my plan: it appears that a N. G. 1 quoted the true discoverer this gave great offence to both editor M. Carr, who at my request caught and partner, which added to a latent another for me, which Dr. Harlan jealousy or envy of iny labors, in- took out of $\mathrm{my}$ hands in the preduced both to break with me, and sence of Mr. Carr, when I ghowed write me very unbecoming letters. him distinctly the want of apodal

The letter of Dr. Harlan inserted fins forming a distinct N. G. from in this absurd review is dated only a Achirus. Three other fishes unfew days after, and evinces his hos-known, to Dr. H., were lent me to tility by two false statements 1 . He describe, but returned afterwards as pretends that I never saw the bones, recpuested, , with the names given of the Aulaxodon or Megalonyx, till them. So much for Dr. H's veracity. in his possession. 'This is not only Concerning the double review of false but preposterous, since I had $\mathrm{Mr}$. F. the first relates to $\mathrm{my}$ enuthem for several years under my meration or rather only to the six care, while Curator of Mr. Clifford's first objects in it. I am accused of Museum after his death, when re- imposture, puerility and lack of $\mathrm{Ge}$ moved to Transylvania University; ological knowledge; but the reviewbut I had seen all the fossils of Clif-er has mistaken his own faults and ford's Museum, since 1818. As to deficiencics for mine! 


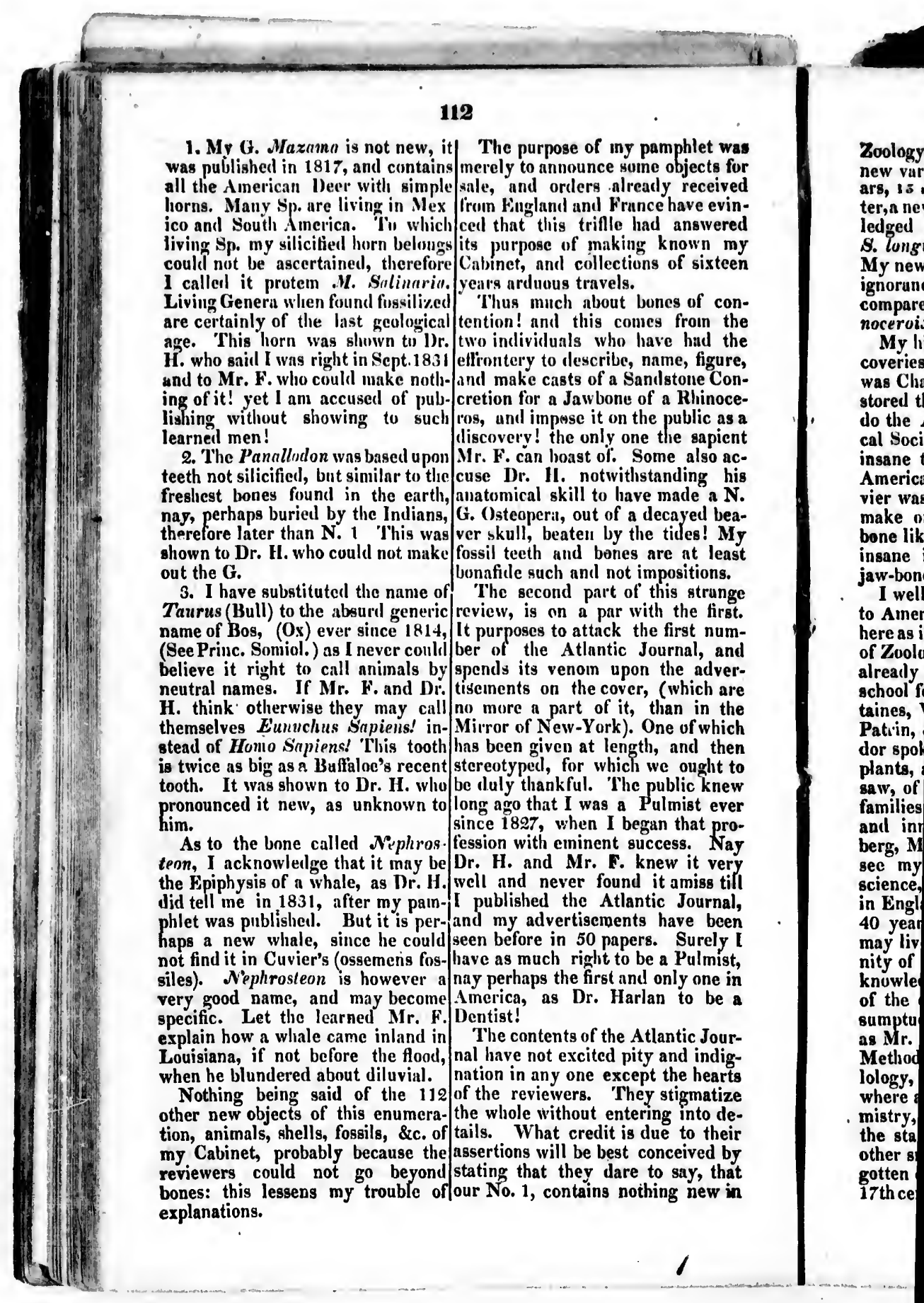


118

Zoology, while we have in it several of other pioneers and precursors of new varieties of Jaguars and Cougu- Knowlerlye will become the leading ars, is naw auimils in Cuvier's fet- doctrines of this age.

ter, a new Salinuaniler, since acknow- But l have perluapis, lestowed too ledged as very distluct from his many lines on such " tissue of abS. longricauda, by Prof: Green, \&c. surdities und false statements as this My new views of geology are called shancful rhapsody contains. It will ignorunce; but theirs is darkness recoil upon itself, ancl bring discrecompared to mine, withess the $/ \mathrm{lh}$. . lit upon the Jourual of Geology, as noceroides!

My historical and philological dis- liberal nor competent.

coveries are called insane? Thus If $\mathrm{Mr}_{\mathrm{r}} \mathrm{F}$, has been successul as was Chanpollion iusane when he le- a lecturer, and in other thingis, he stored the Eyyptian Antiquities as ! has tailed as an editor, a mun of gedo the American. Tlie Geographi- neral science, und even as a Geolocal Society of Paris must have been gist. Ile has disgusted many perinsane to reward my Memoirs on sons by his proul and overbearing American and Asiatic Negroes. Cu- sufliciency. He has been the first vier was insane when he dared to to assail in myself, one of the most make out a Gelus out of a single peaceful members of society, and a bone like myself, but $\mathbf{M r}$. F. is not dlevoted friend of science and insane in calling a rolled stone a Kowleclue for 30 years past, a Vejaw-bone, and making a gellus of it! ternn in Sicience us he once called

I well remember that when I cane ine. As he is neither a Zoulogist, to America, in 1802, Linueus was nor a Botanist, nor a Philologist, here as in England, the nec plus ullra nor an Antiquarian, although 100 of Zoology and Botany, while I who proud to acknowledge it, he cannot alreacly belonged to the French understand $m y$ labors and rails at school founded by Jussieu, Desfon- them, like ignorant men so often do taines, Ventenat, Lamark, Cuvier, at learning, or whatever is above Pativ, \&c. and in iny youthful ar- their comprehension.

dor spoke of the treasures of new 'The whole drift of his rhapsody is plants, animals and lossils which 1 to injure me in the opinion of some gaw, of new genera, and the natural distant readers, compel me to cry families; I was deemed a rash youth mercy as intimated, and cry in and innovator by Barton, Muhlen. vain! But my labors are known and berg, Mitchell, \&c. I have lived to will be known where those of $\mathbf{M r}$. see my youthful rashness become Featherstonaugh, (or Feather-Stone science, and the new school adopted as he is properly called in New Enin England and America, after 50 or grland, since all his Stones and Bones 40 years delays and struggles. I are mern Feather's, never were, nemay live yet to see my mature insa. ver will be, nor evel call be, since nity of improving every branch of he has made no discovericy! while I knowledge, become wisdom, in spite count mine by thousands, having of the obsolete doctrines and pre- been the pioneer of discoveries in sumptuous conceit of such reviewers mmin natural and historical sciences as Mr. F. and Dr. H. The French in North America and South Europe Methodic Schools of Geology, Phi- from 1798 to 1832, having travelled lology, \&c. will soon prevail every 20,000 miles, ulways collecting or where as they have already, in Che- clrawing. My illustrations of 30 mistry, Zoology and Botany; when years travels, with 2000 figures will the stale doctrines of $M_{1}$. F. and soon begin to be published, and be other snails in science, will be for--superior to those of my friend Audugotten or set aside, like those of the bon, in extent and variety, if not ifth century; while mine, with thoselequal in beauty. I shall study and 


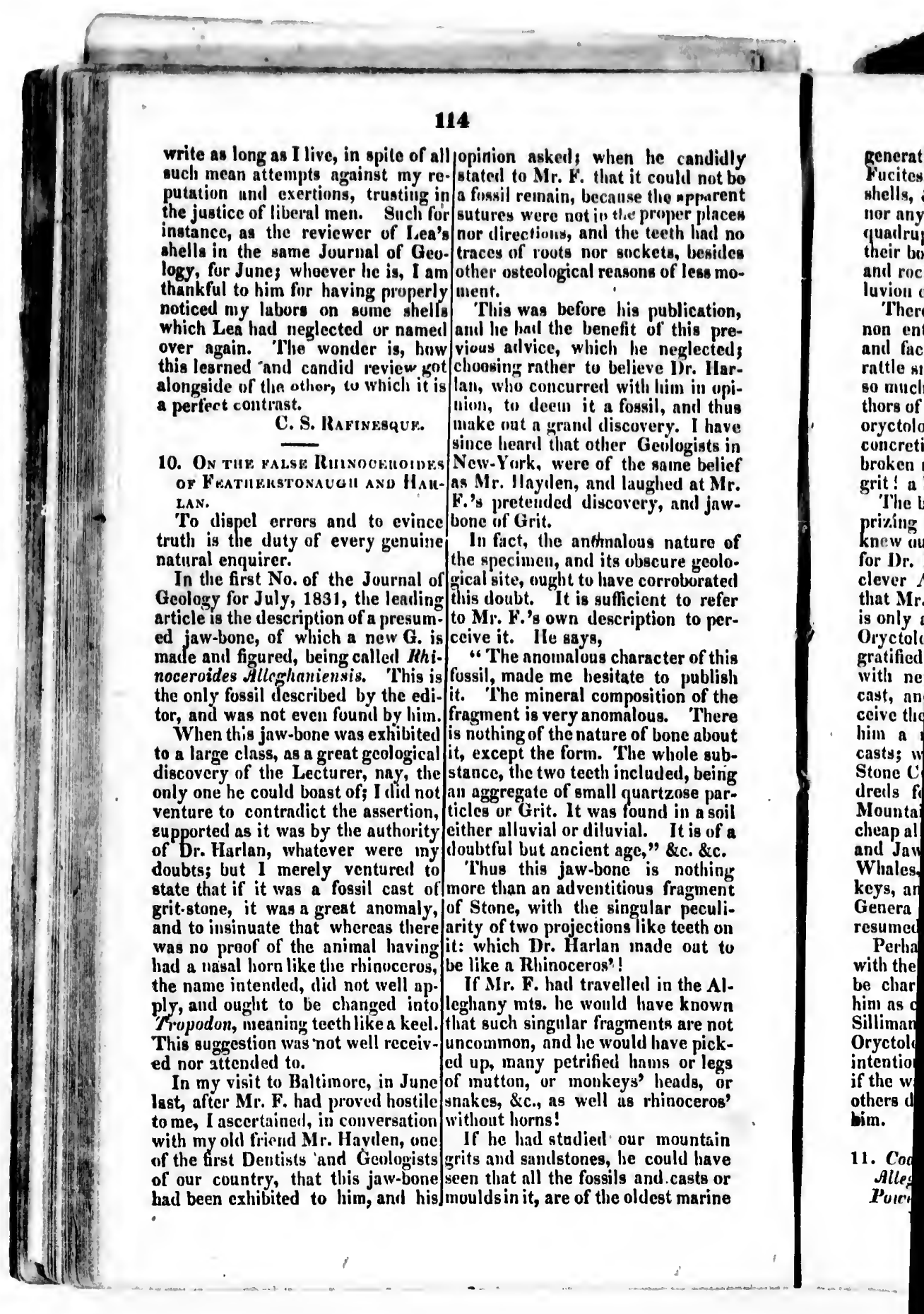




\section{5}

generation of Beings. Marine plants, Dr. W. H. P'owell, of Baltimore, Fucites, 'T'orebrutulites, nunl' other' whou is a very inteligent fisologist,alshells, \&c. 'I'herelore that no boules, thourh of the II eruerian schongl, has nor any terrestrial mimimil, unch less furrushled $11 \mathrm{~s}$ somo facts respecting quadrupells can be found there, nor (lio Conl Mlines of Pennsylvania their bones decay in it, liorm inoulds which lie deems of Chemical formaand rocky casts washed away by di- tion in concave basins, und by no luvions or allusion!

'Therefore, this Mhinoceroides is a proposes to publish in Silliman's non entity! a blumler in cloctrine Journal these results of his long reand fact, worse than t'us petrilicel searches, we shall merely give here rattle snake of Silliman's Journal, one of the facts communicated by so much riliculed by both the au. lim.

thors of this egregious geological anil $\Lambda$ t the Nantico Falls of the Susoryctologicul crror. $\hat{\lambda}$ mere cusual quehannal, near Wilkesbarre, Luconcretion of indurated sand, or zerne county, the following are the broken rolled frament of samlstone succession of formations, where Coal grit! a lusus natura like $\mathbf{M}$ r. F. Mlines are formed in a kind of conThe blumler is great, it is not sur- cave lisisin, well displayed at the falle. prizing in Mr. F. who never yet First formation, thin soil, newest knew our fossils; but it is shameful of cousse.

for Dr. Harlan, who is otherwise a Seconil, Slate, five to eight feet clever $\Lambda$ natomist. It would prove thick, newest stone.

that Mr. F. with all his pretensions, 'Third, Millstone Grit, ten feet is only a pseudo Geologist mul no in the iniddle, thicker on the sides Oryctologist at ail. Since he has of the basin.

gratified Prof. I3uckland ani uthers Fourth, Second Slate ten feet in with new easts out of his pseudo the middlle, becoming gradually 100 cast, and if he has succeeded to ile- leet on the sides.

ceive then, we venture to surrest to Fifth. First $\Lambda$ nthracite Coal, 15 him a manufacture of such fussil feet thick.

casts; we shall if he wislies, send Sixtl., Third Slate, 15 feet, 30 Stone Cutters to carve them by hun- on the silles.

dreds for him in the Alleghany Seventl, Second Anthracite Coal, Mountains, and furnis' him very seven fect thick.

cheap all kinds of Sun linume Bones, lighith, Milstone Grit, with conand Jawbones of Camels, Gilnafes, rromerate, 125 feet thick.

Whales, Lions, Manmoths, Mon- Ninth, Bluish Sandstone with keys, an!l even Men! witl $100 \mathrm{~N}$. particles of Mica in it, 100 feet Genera to grace his Journal when thick. resumed.

'Tenth, Reel Sandstone, 125 feet Perlaps lie was served in that way thick in the middle, less on the with the Rhinoceroides, \& this would sides.

be charity to him: it would prove Vileventh and last formation reachhim as credulous as Dr. Nitchell, or ed. White Grawacke, very thick, Silliman, or Eaton, and irnorant of and formiur also a basin or concave Oryctology; but would clear hisn of support to the whole.

intentional imposition on the public, This Coal Basin therefore, has if the warnings of M. Hayden and been penetrated or can be traced others did not rather operate arainst about 450 feet in the centre, and him. C.S. R. aluve 600 on the sides it aftords a bim. 11. Coal Mrines of Nantico in the connected with Coal in the AlleghaAlleghany Mountains. By Dr. nies; but other localities display difPouepll. 15

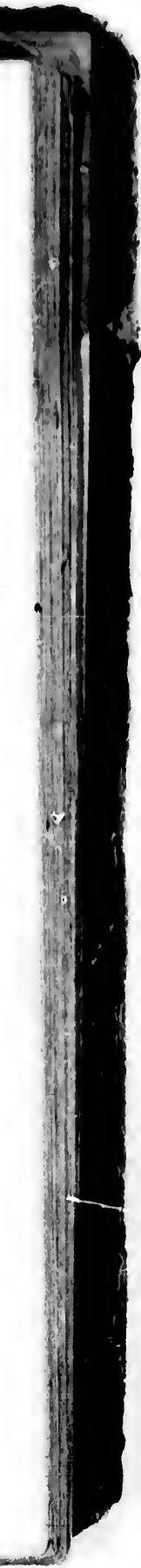




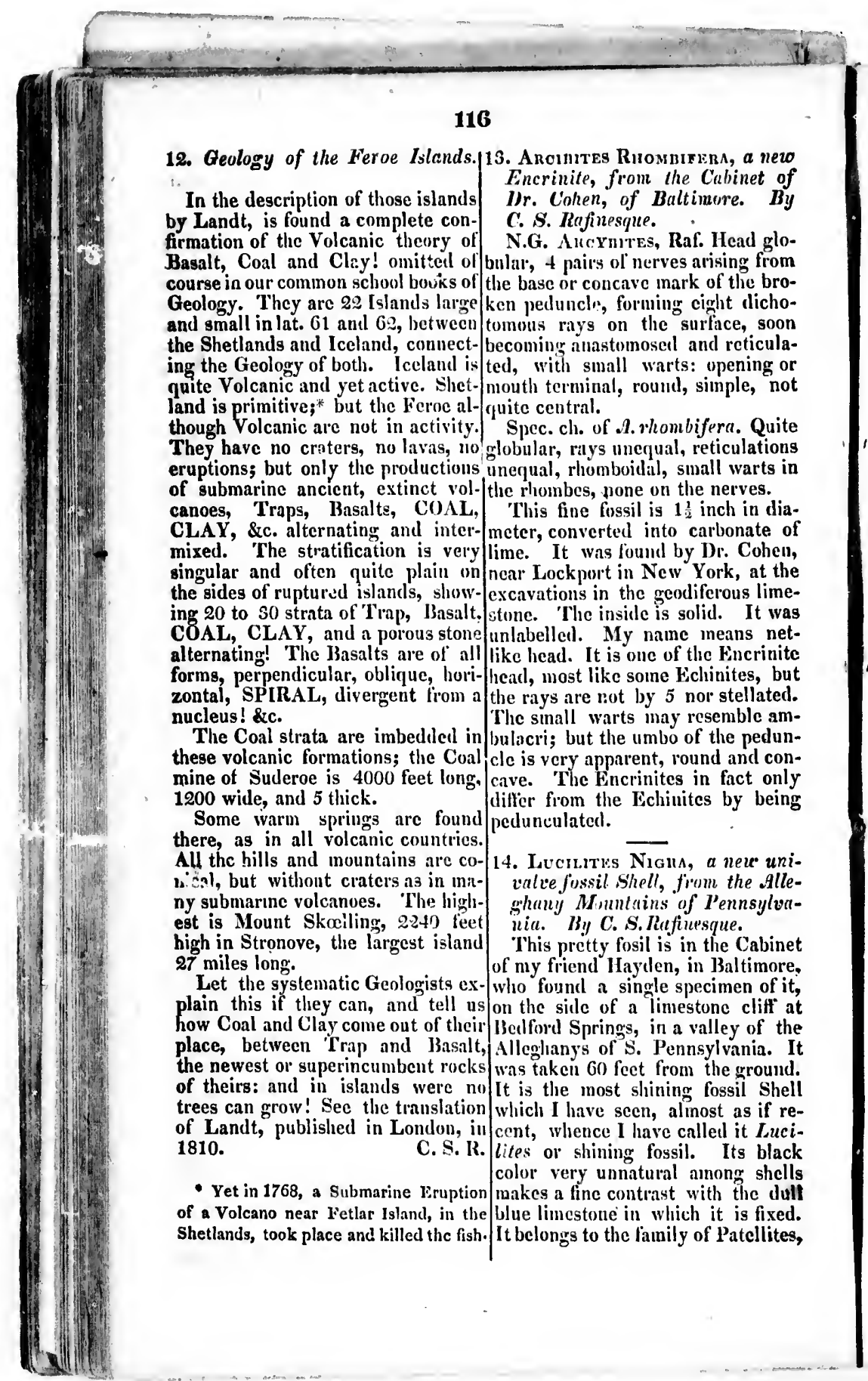

and or ing el radiati

G. outsid. outsid ations, openin sidle, b double an inc

15. A

CHy

In

las pu few d are ne tory.

A s

this ye

on the

the Ir joint $t$

s usur

Alt
vague

tentio

notice

An

wehog

meani

the la

tion.

them

now

long

ea

ters

Ame

era,

cas,

north

Donl

or 70

natic

a kin

empe

the 


\section{7}

and only differs frem Patella, by be-jarise and a war of 100 years with ing elliptical and smooth, without (lyis empire of the south, long civil radiations. wars in the north, \&c. A body of

G. Lucilites Raf. Simple univalve people escaped in the mountain of pateloid sluell. Elliptical entire, Oswego, \&c.

outside convex smooth withont rati- $3 \mathrm{l}^{\text {. }} 1500$ years before Columbus ations, inside concave smooth. No or in the year 8 of our era, Tarenyopeniners nor fissures. Sp. T..nigra. Black slining out- this people out of the mountains to side, both ends equal obtuse. Length the river Yenonatateh now Mohawk, double of the breatilı. Over half where 6 tribes form an alliance callan inch in the specimen. $\quad$ ed the liong-house Aroneaseah. Afterwarls relucel to 5 , the sixth 15. Aneucas Historr-Asciexr spreading $W$. and $S$. The KatitanChronology of rus Oscuys on ol since 'Tuscarora came from this.

Inoquors. By David Cusick. $\quad$ ka now Mississippi.

In the traditions of the Tuscaro- 4 ll. In 108 the Konearawyeneh ras published by Cusick in $182 \%$, or Flying Heads invade the 5 nafew dates are found; but these few tions.

are nevertheless precious for His- 5 th. In 242 , the Shakanahih or tory. A small volume has been printed ern tribe become Caniloals, return this year by the Sunday Sclool Union and desolate the couniry; but they on the History of the Delaware and are overthrown and driven north by the Iroquois Indians, in which their Taren yawaron II.

joint traditions are totally neglected 6th. Towards 350 Tarenyawagon as usual with oul actual bookmakers. 111. defeats other foes called Snakes.

Althourh Cusick's dates may be 7 th. In 492, $\Lambda$ totarho I. king of vague and doubtful, they dieserve at- the Onondagas quells civil wars, betention, and they shatl be concisely gins a dinasty ruling over all the 5 tention, and they shatl be concisely gins a dinasty ruling over all the 5
noticed here. Anterior to an $;$ date, the kag- yet in 1142. Events are since rewehoewe (pronounce Yaonyhuliuy) ferred to their reigns.

meaning real people, dwelt nurth of 8th. Under Atotarho II. a Tarenthe lakes, and formed only one na- yawagon IV. appears to help him to tion. After many years a body of flestroy Oyalk-guliver or the Big them settled on the river Kanawas, bear.

now the St. Iawrence, and after a 9th. Under Atotarho III. a tyrant long time a foreign people came by Soluanrowah arises on the Kaunaseh sea and settled south of the lakes. now Susquehanah $R$. which makes First date. Towards 2500 win- war on the Sahwanug.

ters before Columbus' discovery of 10th. In 602 under Atotarho IV. America or 1008 years before our the 'Towancas now Mississaugers era, total overthrow of the Towan- cede to the Senecas the lands $\mathbf{E}$. of cas, nation of giants come from the the R. Niagara, who settle on it. north by the king of the Onguys, 11 th. Under Atotarho $V$. war beDonlitonla, and the hero Yatatan. tween the Senecas and Ottawahs of 2d..'Three hundred winters after Sandusky

or 708 before our era, the northern 12th. "Towards 852 under Atotarnations furm a confeleracy, appuint bo VI. the Senecas reach the Ohio a king, who goes to visit the great R. compel the Ottawalıs to sue for emperor of the Golden City south of peace.

the lakes; but afterwards quarrels 13 th. Atotarho VII. sent embas-

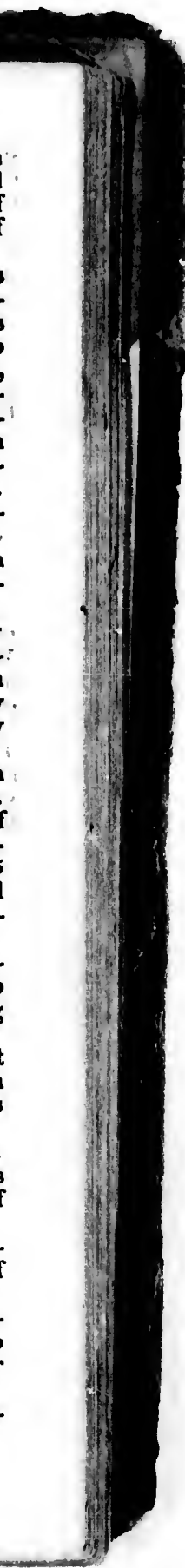




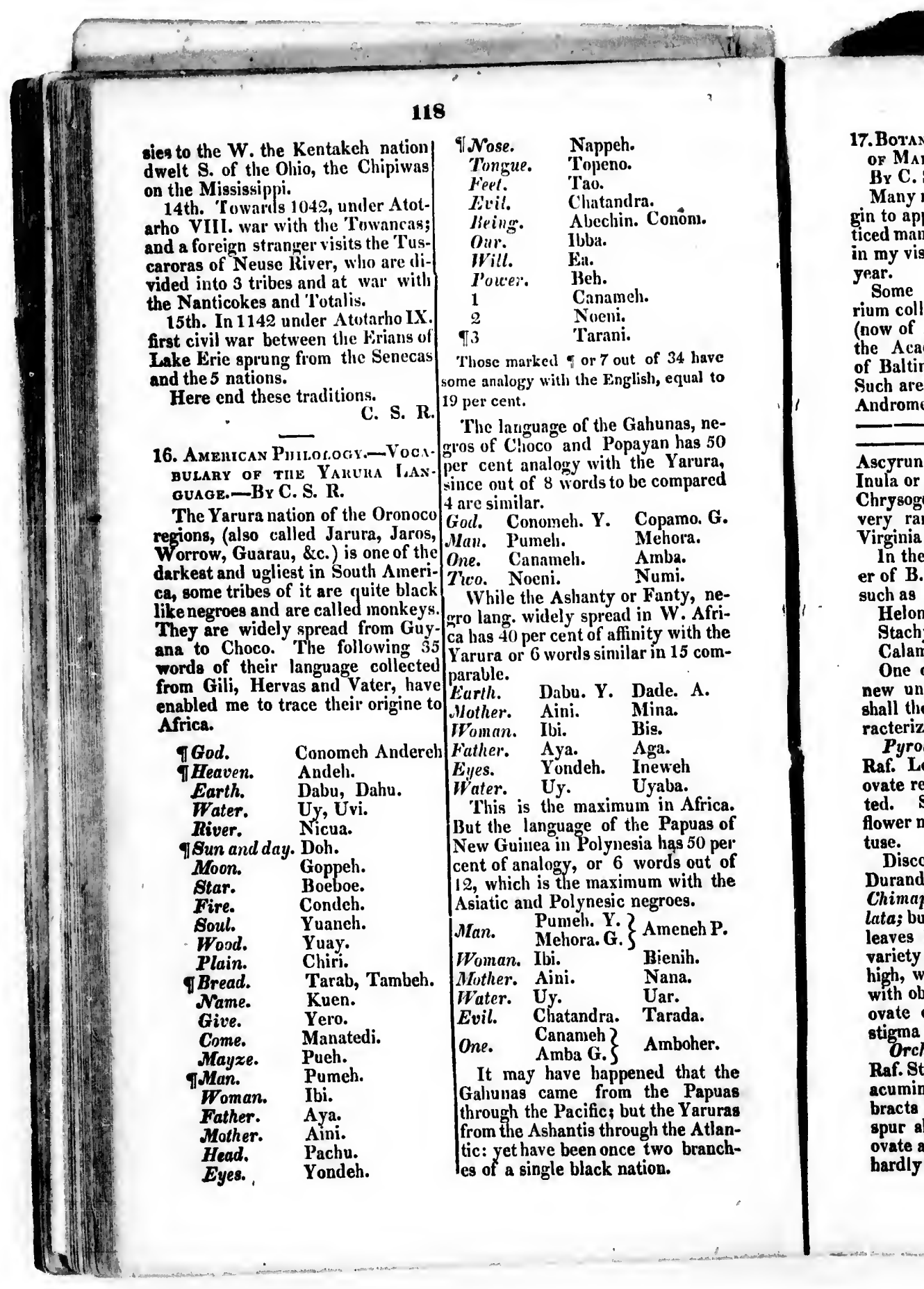




\section{9}

17.BotanY-New and manepeants Discovered and collected by $D$. of Maryband nzast Baltimone. W. Fisher. Vely different from By C. S. Rafinesque. $\quad$ O. cili"ris, flowers smaller, saftion Many rare or Southern plants be- color, not ciliated. Slender plant gin to appear near Baltimore. I no- 1.5 iuches ligh. Probably an Habeticed many in 1804 and 1819. Also naria. in $\mathrm{my}$ visit an: herborizations this in my

18. Six New Frrs of Oregon.

Some are preservel in the herba- Lewis and Clarke discoveret and rium collected by Mr. Elias Durand noticed without names, many years (now of Philade lphia.) presented to ago, several fine Fir trees of the Orethe Acadeny of Natural sciences gon or Columbia country. 'These I of Baltimore, where $I$ saw them. named and characterized in 1817 in Such are the. $\quad$ my Florula (regonensis, and since Andromeda marginata of Dulamel. sent them to Prof. Decandolle. I Acuminata? Duh. now give here my names antl speciAscydosa of Wildenow. fic characters of those 6 new spo of
the Genus sthies of Jussieu, \&c. Inula or biplogon argentcum. 1 . Abiestrimoma R. Gigantic Fir Chrysogonum Virginiaumu I. this (First Fir L. C.) bark and branches very rare plant $I$ found in West scaly, leaves densely scattered, peVirginia also.
tiolite trigone acuminate and stiff-

In the Herbarium of Dr. W. Fish- Statel to be the largest tree of North er of B. are some other rare plants, $A$ merica, some reaching 300 feet such as 4 high, 200 without branclies, and 42 Helonias angustifolia. $\quad$ feet around. Petiols trigone also, Stachys hyssopifolia. leaves $3-4$ ths of an inch long, 1-10th Calamintha caroliniana. wide.

One of both Herbals were quite 2 . Abies heterophylla $R$. Odd new undescribed and nameless. 1 leavell Fir (Second Fir L. C.) bark shall therefore name them and cin- rimose, leaves distichal petiolate racterize them as follows. very unequal, sulcate above, glauPyrola (or Chimaphila) durandi cous beneath, cones terminal ovate Raf. Leaves few, shortly petiulate. minute flexible-Reaching 180 feet ovate remote serrate, acute, unspot- high anil 6 feet diameter. Leaves ted. Stem naked above uniflore, from 1-4th to one inch long, but all flower nodding, calyx 5 toothed, ob- 1 -20th wide. Is it a variety of the tuse. Spruce Fir:

Discovered and collected by Mr. 3 . Abies aromatica R. Aromatic Durand. It belongs to the S. G. Fir (Third Fir L. C.) branches bulChimapliala very near to $P$. macu-late balsamiferous, leaves densely lata; but differs by broader unspottel scattered, forming 3 rows, sessile, leaves and uniflore stem. Is it a lanceolate obtuse, flexible, sulcate variety of it? Only 4 or 5 inches and shining above, gibbose beneath. high, with only 3 leaves, calyx short Reaching 100 feet high, blisters on with obtuse teeth, petals white ob- the branclies filled with a fine aroovate obtuse, stamens bifid short, matic balsam. Leaves very small stigma sessile thick depressed. 1-8th of an inch long, 1-16th wide.

Orchis (or Habenaria) Crocea 4. Abies microphilla R. Smalt Raf. Stem angular, leaves lanceolate leaved Fir (Fourth Fir L. C.) bark acuminate, spike short cylindrical, rimose, branches not bullate, leaves. bracts lanceolate equalto flowers, densely scattered, forming 3 rows, spur slender equal to ovary, petals sessile, sublanceolate acute-Reachovate acute, labellum nearly similar ing 150 feet high. Like the last, ovate acute, labellum nearly similar
hardly longer, entire.

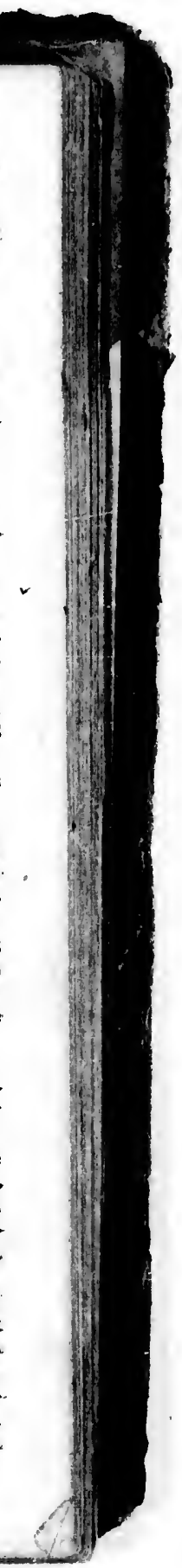




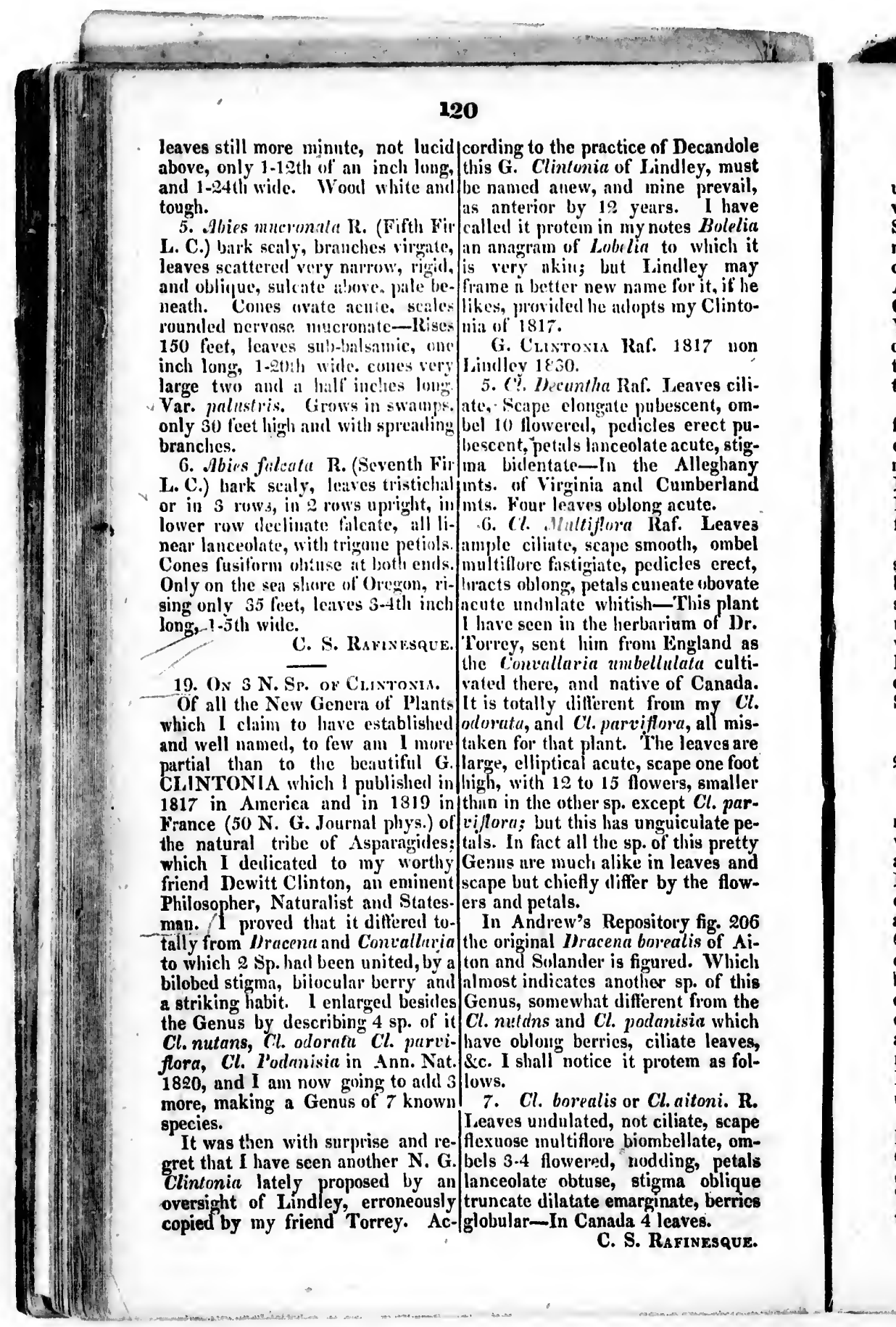


121

20. ON 3 N. Sp. of Eriocaulon. Inucronate, eyes very small round, 1. E. pumilum Raf. Leaves sub. body marbled of two shales of brown ulate recurved pelluciel acute, cour- tail one third of tutal leurrth-In the vex and striated outside, flat inside. river Kentucky. W/umle lenrth 21 Scape stift double than lenves, spi-inches.

raly striated. Capitule hemispleci- 'The $2 \mathrm{~N}$. Sp. belong to the (ix, or cal, scales black obovate obtuse-C. G. Triturus (Triton of some but Annual like all the $S_{p}$ (nn the not Lin.) or salamanders with comCatskill or Kiskanoin mts of New pressed tails.

York, on the margin of the twolakes. 1 . S. or Tr. Intescens 1R. Entireonly one inch hirh. Flowers estival. ly of a dirty pale vellory, without tricolor, base green, midslle brown, spots, tail equal to the body.-In top nearly white. West Kentucky in rocky limestone 2. E. filiformis Raf. Leaves lili- springs in the barrens or glades, 5 form elomerate striate, scape sub- to 6 inclies long.

equal round stifl, capitule hemisphe- \$. S. of Tr. mebulosus R. Blackrical, scales lanceolate olutuse.-In isls with pale or brown clouded spots New Jersey and Virerinia in swamps. on the back, tail nearly conical short Flowers estival, whitislı. Scape one one third of tutal lengtlı.-In sinall foot high. $\quad$ streams and fissures of rocks in the 3. F. Spallaceum Raf. Leaves knobs of West Kentucky, length 3 subulate very short, scape rounil to $t$ inches. C. S. Rifinisgue. hardly striate, base spathaceous,

spatha bivalve obtuse subeyual Psepumis Pamodoxa.

membranaceous. Capitule splierical white, scales ovate oblong obtuseFrom Floricla, seen in the herbartum of Mr. Halsey without a name. Scape one foot high.

C. S. Rafixesque.

21. Erperology.-ON $3 \mathrm{New}$ W TER SALAMANDERS OF KExTC CKY.

The Salamanders are rery nume- [ wis much gratified to find this rous in North America, and althongly year a new Hiviatile shell of the we know now about $40 \mathrm{sp}$. of them, simple tubular form; but the animal as many more remain undescribed. Wals not within. It was found in Prof. Green has found some new Sherman creck, a mountain stream ones this year in West Peunsylvania, "fi" Perry County, Pennsylvania, among which is a remarkable new amoner tlic Allewininies.

Genus with a tubular tongue and 'Ihis strintre shell has something callose toes, which he will describe mysterinus in it. It appears a mass by the name of Grossiplacs. I have of arivel; trourly cencuted, even described alrealy 2 land Salaman- lobliner sometimes iniunte fossil tereders, in N 1 and 2 : I will now ald biatulites atul other linsils. It is not a N.G. and 2 N. Sp. of water Sala- thereline the tulse of a Phryganoa. manders, making s from kentucky. Oince they are all brittle, arenaceous I propose to give hereafter groul lim- or membramaceous. Yet the worn ures and ample description of them. that linms it andelwells in it, as no

N. G. Ecorew Raf. Mouth vergemulusea lin'm tubular shells) is unlarge with many rows of simall fecth kn:win, and I wiss iblal none has ever Opercules a round hole on each sirle been s.en in it. A singular idea was of the neck. Feet with 4 and 5 toes suresested to ine loy Prof. Green that Tail conical carinate above-Sp. E. it might be a fossil shell! Since it is mucronata R. Upper jaw longer funnd in a ricl fossil region; and 


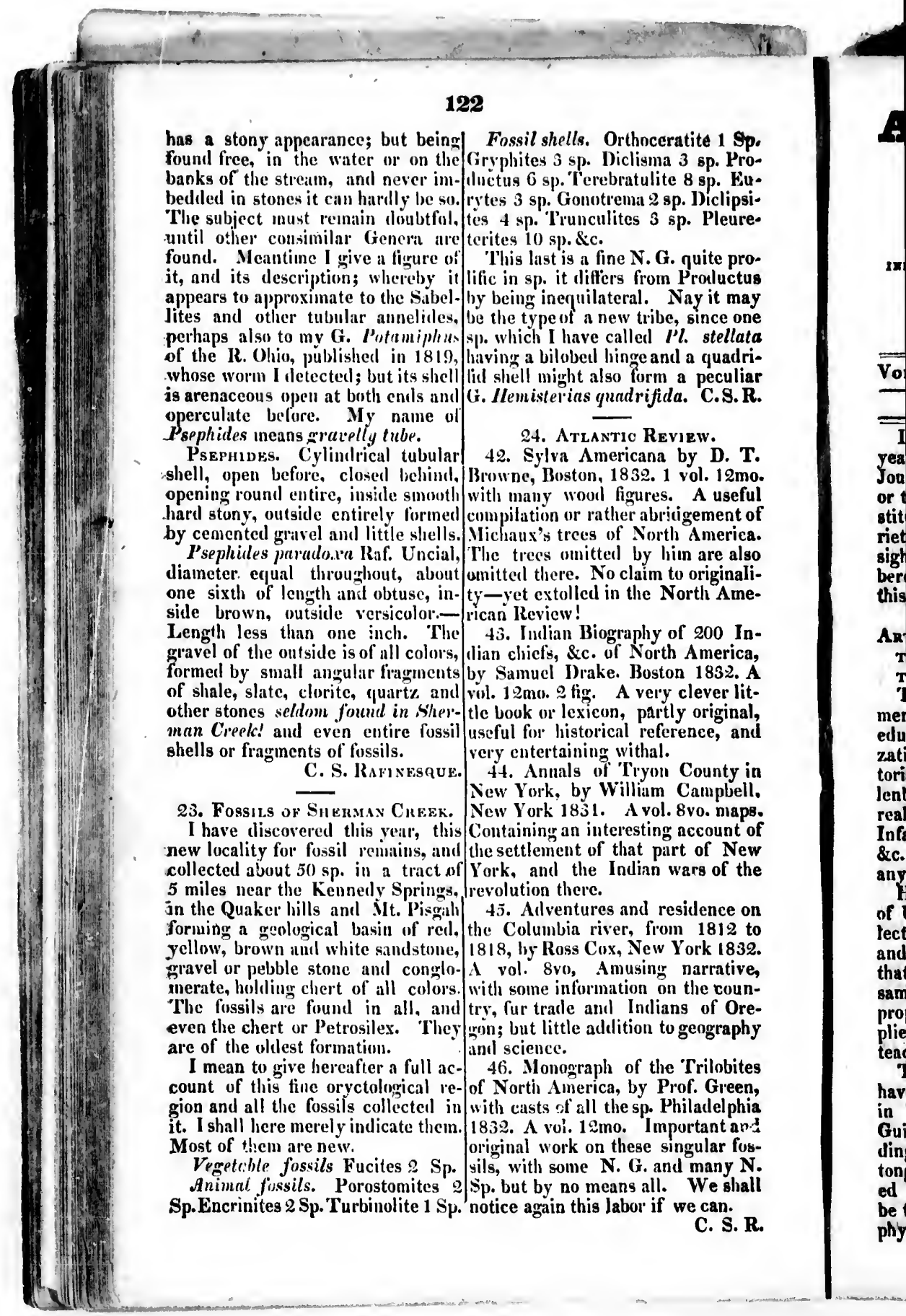


eratite 1 Sp. ia 3 sp. Proite $8 \mathrm{sp}$. Eusp. Diclipsisp. Pleure-

G. quite prom Prolluctus Nay it may oc, since one $P l$. stellata nd a quadrin a peculiar ida. C.S.R.

EVIEW.

a by $\mathbf{D}$. $T$. 1 vol. $12 \mathrm{mo}$. s. A useful ricigement of th America. him are also to originaliNorth Ameof $200 \mathrm{In}$ th America, ton 1832. A y clever littly original, erence, and

n County in Campbell. I. 8vo. maps. gaccount of art of New wal's of the residence on oin 1812 to , York 1832. narrative, on the counans of Oreto geography Ie Trilobites Prof. Green, Philadelphia aportant and singular fosnd many $N$.

We shall we can.

C. S. $\mathbf{R}$.

\section{ATIANTIC JOURNAT

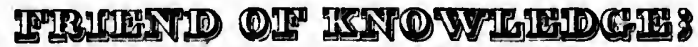 \\ $A$ CYCLOPEDIC JOURNAL AND REVIEW

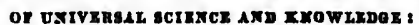

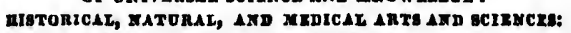

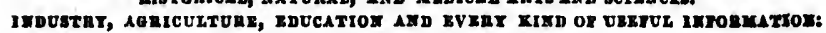 WITH NUMEROUS FIGURES. \\ EDITOR, C. S. RAFIVESQUE, \\ Professor of Historical and Natural Sciences, Es.

\begin{tabular}{ccc}
\hline Vox. I. $]$ & PHILADELPHIA, WinTER of 1832. & [No.4. \\
\hline Krowoledge is the mental food of man.
\end{tabular}

It has been impossible to give this/oratory, mathematics, drawing, nulyear all the articles prepared for this sic, dlancing!!! All this with a sinJournal, owing to the length of some, gle text book, which is Telemachus, or the nature of others; but by sub-although any other widely translated stitutions as great a number and ya-book would answer. Hamilton used riety has been given. By an over- the Bible.

sight the articles have not been num- Jacotot begun to teach on this bered in succession as contemplated: plan in 1818 in the Netherlands, this omission is now repaired here. where he contrived it in order to this the French language to the

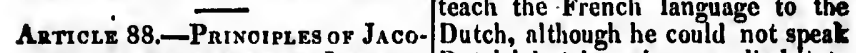
Tor on His system of Isstuuc- Dutch! but has since applied it to

This age so fecund in improve- every kind of instruction. In. I82 This age so fecund in improve- he became the subject of attention,
ments has not neglected to improve and in 1828 lis method was spread education, the great basis of civili- through France. Wonders are rezation. The intuitive and moni-lated of it, in Lyons a whole school torial plans, those of Pestalozi, Fel- was taurlit to read and write in 15 lenberg, Rensalaer, Lancaster, are days! and in 8 months the whole real improvements, as well as the course of education was completed, Infant Schools, T'eachers Schouls, by a single book! who can believe \&c. But has the system of Jacotot this? any similar claim? He calls it, the Natural Method chiefly

of Iniversal Instruction and Intel- 1. God has endowed the human lectual Emancipation, a very bold mind with the power of self instrucand assuming title; nay he asserts tion-True.

that it is entirely new, while the 2. The clild is to speak what he same principles had long ago been learns, the teacher to listen and diproposed in France, and lately ap. rect-This is clone in the Rensalaer plied by Duficf and Hamilton to school, and many others.

teach languages.
3. A constant repetition of the

The outlines of Jacotot's System first words and things learned, is have been translated and published required-This is parrot like. in Philadelphia, 1831, by Victor 4. It is needful to commit to meGuillou, diviled in $S$ parts. 1. Rea- mory the 6 first books of Telemading. 2. Writing. 3. Vernacular chus, word fur word without a bluntongue and grainmar. It is assert- ller.-Absurdity!

ed in addition that every thing can 5. Intelligence is the same in all be taught in the same way, geogra-beings, and therefore the aptitude to phy, history, languages, composition, learn-Quite false.

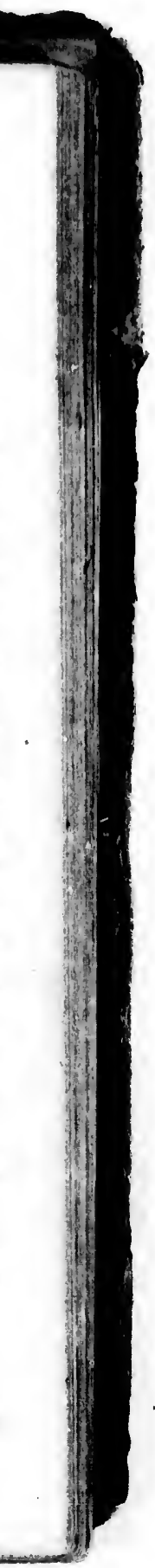




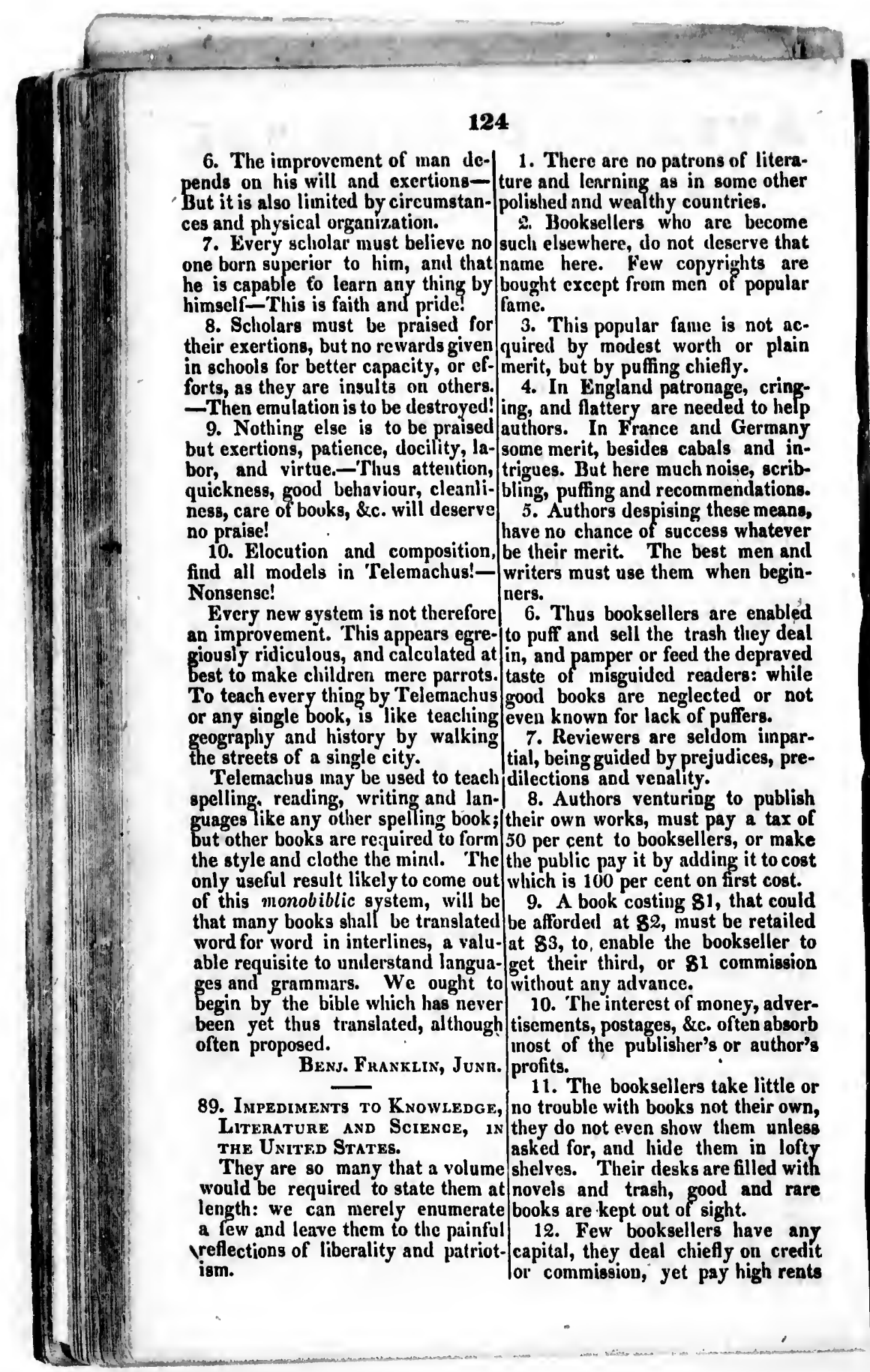

for fi

thus

tal,

tal, a

this

could

ausp

for a

quire

edito

15

almo

and

odic

amo

scrif

is $r$

mon

are $y$

dom

or $p$

well

Age

Sur

to th

seve$$
\text { ed }
$$

Uni

Uni
Lib

fess

whi

be

cha

$$
\text { edg }
$$

im 


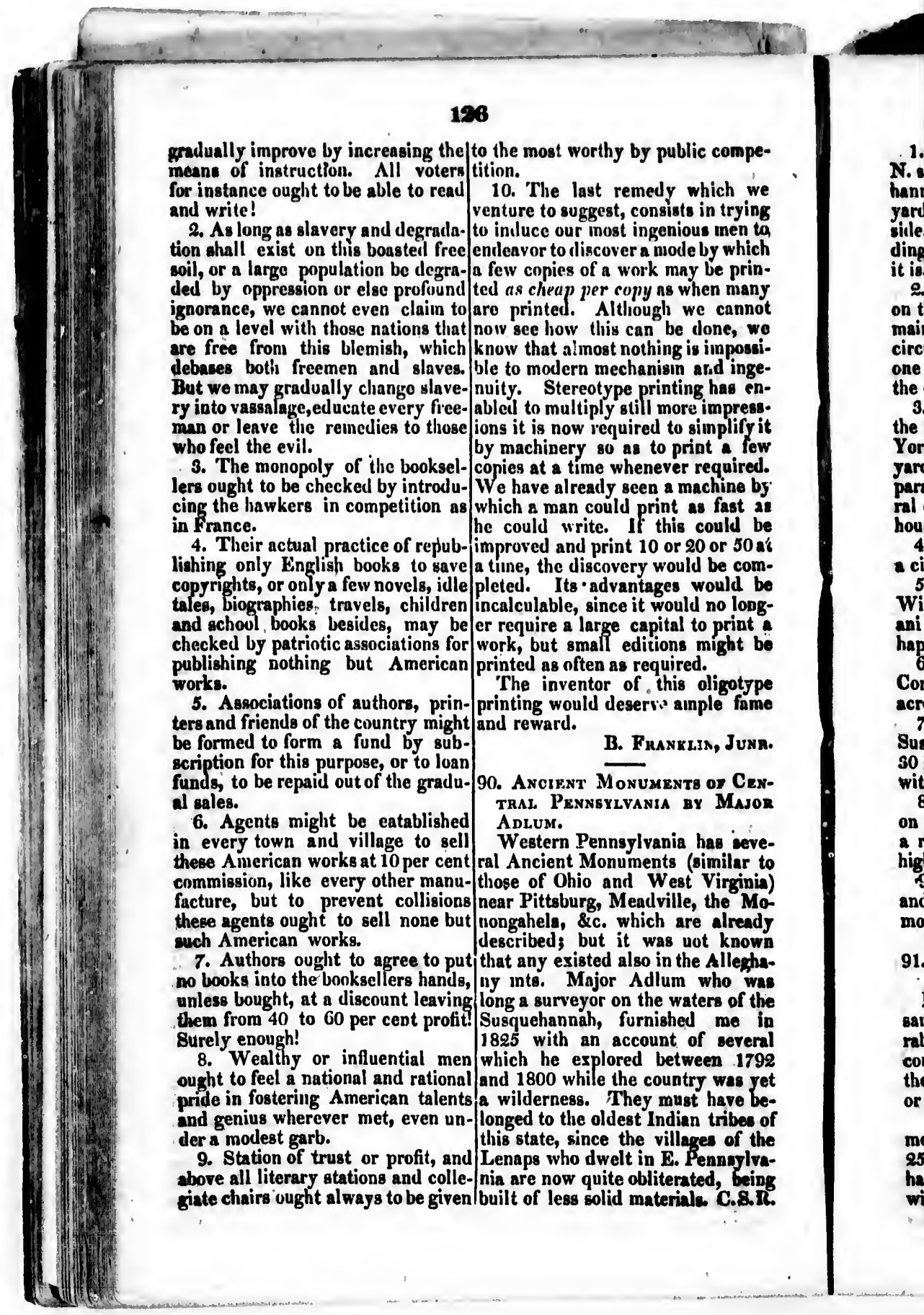




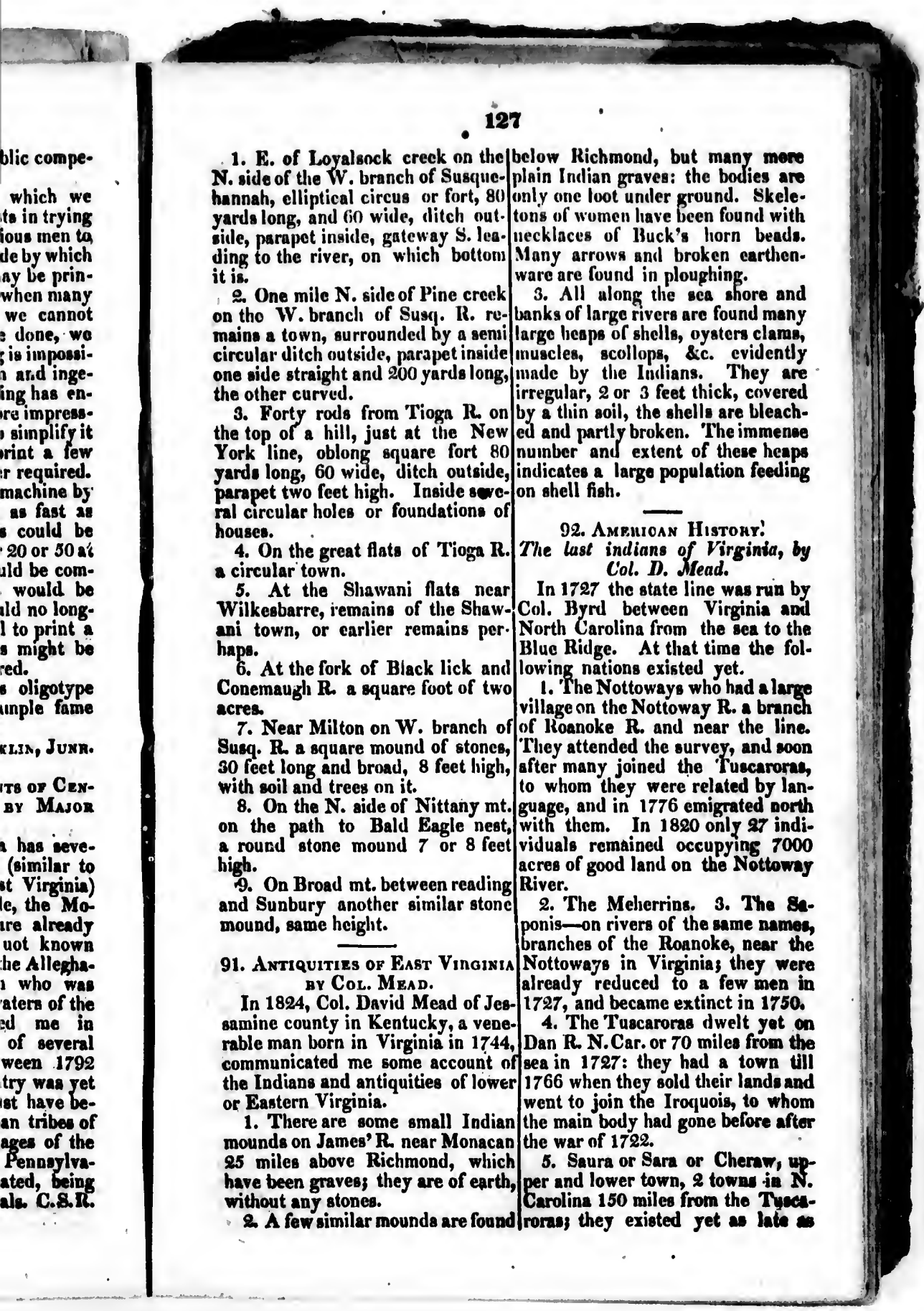




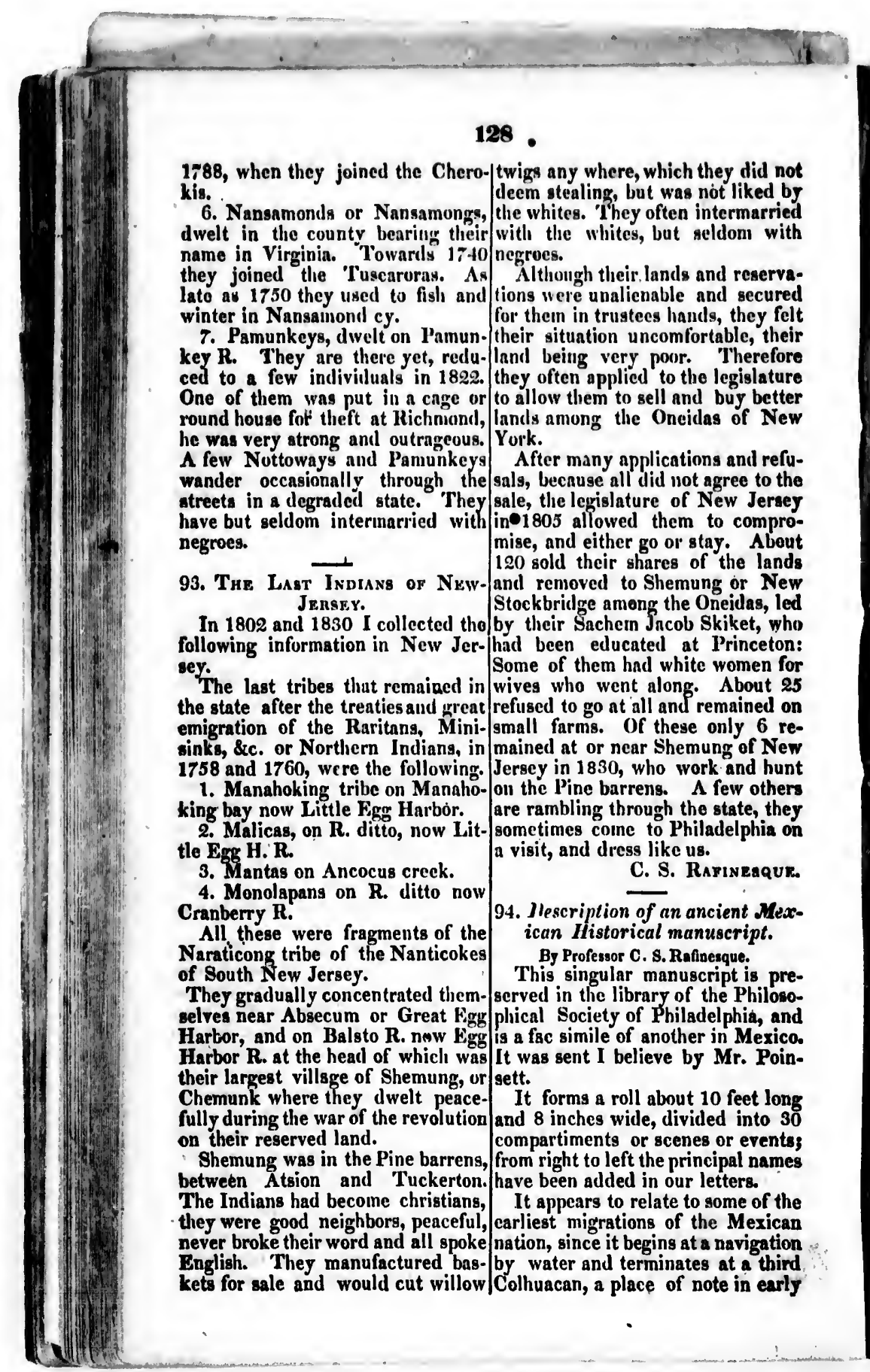


180

2 men kneeling to 2 men sitting, 5 3. Pachamama or the eartly sheaths or ages of 520 years. properly world mother.

27. Chimalazotl, 3 steps, a war- 4. Apuinti, or the sun, properrior leading a slave.

28. Huitzilihuitl, 3 steps, a warrior leading a slave to the king $\mathrm{Coz}$ coxth sitting. This is the Cuxcos of Aztecas to whom they become glaves, and therefore these annal refer to those tribes who enslaved them, under Cuxcu.c 14th king of the Chichimecas or Acollsuans.

29. Third Colhuacan, a mountain, 2 steps, 4 years, 2 men, a vase betweeti them.

soth and last scene or event.

Nameless. Three kings sitting, steps, several men, a cone below steps, several nen, a cone below diers with swords and tongues.

The whole number of computed Jears from the 12 th scene, amount to 816 years before the subjugation of the Aztecas and the building or occupation of the third Colhuacan the date of which is in 1314, therefore the beginning of these annals go to the year 498 of our era; but how much earlier in the previous ages is uncertain. It appears that they dwelt 3 ages or 312 yearsin the first dweit 3 ages or 312 years in the first
Collhuacan. If the feet or steps denote times or cycles the chronolog would be changed and increased. is desirable that this manuscrip should be engraved.

4. Apuinti,
father lord.

5. Churi-inti, or son of the sun.

6. Inti-vauqui, or brother of the sun. These 3 deities form a triad or trinity called Tarigatanga, being. 3 in 1 or 1 in 3.

7. The moon or Cuilla

8. The Iris or Alla, Illapa

9. God of thunder, air, and wind, Chuquilla.

10. The stars, Chillay, Aclla, the chief Chasca is Venus.

11. Apachitas or tops of mountains.

12. Conapas or Malquis. Spirits, Cunay or Supa is the Devil.

2d Period. Antidiluvian dynasties of Ayar. 1. Cacha. 2. Uchu. 3. Sanca. Great flood of Mamacocha (mother ocean.) 3d Period. Of legislators and conquerors.

1st Dynasty. Collas.

2d Guancas.

3d Xauxans escaped from the great Hood in the mts of Xauxe and Collao, part of the Ritisuyv

\section{PERUVIAN HISTORY.}

Table of the successive Dynastie and Incas of Peru.

or mow. $x$ auxan D. last-

ed till 1534, last king was Atoya.

4 th. Zipanas, of the Collas.

5th. Cagnas, Queens who conquer the Zipanas.

6th. Chon or Con, legislator caine from the North, with a na-

This is an extract from my tion of white bearded men, who bistery of the Americans, the built Tiahuanaco.

suthors consulted are chiefly 7. After a second flood InHerrera, Lavega, Acosta, Laet, tillapac, the last king of TiahuaValera, Gomara, Polo, Amich, naco, divides his empire into 4 Touron, Garcia. kingdoms for his 4 sons.

1st Period. Theogony. 1 God Manco, king of the North. or triad. Pachacamac (world Colla, of the South. soul) or Pachayaca (world heavenly) or Achachic (celestial creator.)

Pinaliua, of the Weat.

8th. Cara or Cari, or Pacha. 2. Mamacocha or motlicr ocean cam, who came from the South 


\section{1}

conquers 'Tialıuanaco, the Chons 5. Yupanqui I. or Yacarguabanished. $\quad$ gue or Lloque, nephew of last,

9. Tice or Viracocha I. (man in 1167. Queen Cava. Progeny of the sea,) legislatul come from Huaynana.

the south: sinco worshipped. Al- 6. Mayta Capac in 1197. cavica was king of Cosco. Queen Cuca. Progeny, Urcar

10th. Viracocha II. Another mayta. Begins to extend the legislator, came by sea and dri- empire greatly over Peru.

ven a way to sca by the Cagoas 7. Yupanqui II. or Pachuti or Canaris. . Capac in 1227. Queen Cury

11 th. Cagnas queens again in llpay. Progeny Aumayta.

E. Peru. Chapera last 1538. 8. Yupanqui III. or Roca, in Chimu in W. Peru, lasted till 1527. Queen Micay. Progeny 1408. Clıancas in central Peru Vicaquirau or Vizaquimo.

the last king Hancohuallu leaves 9. Yupanqui IV..or YahuarhuPeru in 1350. 12th. Cari and Chipana or Ca-Progeny Aylli.

panac, two kings of the Collas, 10. Viracocha in 1315. Queen begin new dynasties towards 840 Runtu. Progeny Cozco.

of our era, and are at war for 400 11. Urco in 1372. Tyrant so years till both submit to the Yncas worthless as to bo omitted by

13th. Tocabo or Royal line, many, deposed.

descended from Manco. Several 12. Pachacutec or Manco II. kings mentioned, who relgn in or 'Titu-capac, in 1375. Queen N. Peru over the Yuncas, first Huarca. Progeny Incapanaca. king Chincha Camac, a legisla- 13. Yupanqui V. in 14,25. Qu. tor, all the kings called Clinchas Chimpu. Progeny Incapanaca II. and Mancu. Rimac was one 14. Yupanqui VI. or Tupac deified. Cocapac was kiug to- Yaya, in 1450. Queen Oello. wards 1050. 'Towards 1380 two Progeny Capac.

kings, Cluqui became vassal in 15. Huayna Capac in 1481. 1388, Cuyz in 1402. 4th Period. Dynasty of the In- tu, Toto. Progeny 'Tumipampa. cas or Yuncas ol Yncas, or Ingas 16. Huascar or Inticusi huallor Inguas.

1. Guanacaure or Ayarache, Progeny extirpated. Deposed by of 'Tocaloo race, king of Pacari- 17. Ataluualpa his brother in tambo, his queen Ragua, towards 1526. Usurper, was king of 1080.

2. Aranca, king of Tamboqui- 1533 . ro towards, 1090, queen Cona. Second Series of Incas after the 3. Manco I. or Maneo Capac, brother of the two last, becomes 18. Toparpa or Atahnalpa II. king of the Quichuas, and built set up by the $S p$. in the N.1533. Cusco town 1100. His queen 19. Aticoc, set up. by the QuiOello or Colo. His posterity tans, nominal for a few days 1533. Chima. Quilliscacha, killed by
20. 4. Sinchiroca, son of $s$, in 1137 Ruminavi in 1534 .

Quee." Cora or Achiola, progeny 21. Ruminavi, in 1534, indoRaura. 17 
peedent in the Andes for scveral|longs to their lato independent

years.

2.2. Manco III. son of Huayna,

rightful Inca in S. Peru, fiom

1533 to 1555 , called Elinga by

the Spaniards.

23. Sayri tupac his son 1555

to 1561. Diego of $\mathrm{Sp}$.

24. Cuzititu his brother 1561

to 1569 . Philip I. of Sp.

25. Tupac Amaui I. his brohistory.

\section{American language.}

Walltani or Mandan.

The rocabularies of languages collected by Lewis and Clarke, in their memorablo journey to is said they never pablished. It Sp. all inclependant of Spain, in Vilcapampa; last beheaded.

26. Paullu I. Christobal of $S_{p}$ set up by them at different times in opposition till 1576, was son of Huayna.

27. Paullu II. Carlos of Sp.his spn, from 1576 to 1586 .

28. Paullu III. Melchior Carlos son of last 1586, exiled to Spain in 1602, dies there, of grief 1610 .

Interregnum, but Incas acknouledged secretly by the Peruvians. 29. Man

the Andes.

30. Torote, secretly from 1712 to 1737 , became independant in Andes till 1740.

31. Apu or Huaynacapac II. Juan Sautos of Sp. independent in Andes from 1742 to 1755 , when sent to Spain.

22.Tupac Amaru II. Cordodanqui of $S_{p}$, independent in the South from 1780 to 1782 .

33. Tupac Amaru III. his brother and successor 1782 .

34. Pumacagua, revolt in 1813

85. Manco IV. or Yupanqui VII. was Inca Protector General of the Indians appointed by $\mathbf{P a}$ triots in 1818 .

36. Lauricucha, short revolt in 1828.

The series of Spanish kings 1 and viceroys of Peru belongs to the colonial history, the series of 3 late independent inlers anil pre- 4 sidents of Peru ani Bolivia, be- 5 mado no use of them; since his
death they have disappeared, and death they have disappeared,
cannot be traced any where.

F met in Lexington, $\mathrm{Ky}$. Mr. Georgo Shannon, who was one of the companions of Lewis in that voyage, and who furnished me with some worls of the Mandans on the Upper Missouri, who he said call themselves Wahtanis, these added to a few scattered in Lewis' 'Travels, form the following 32 words.

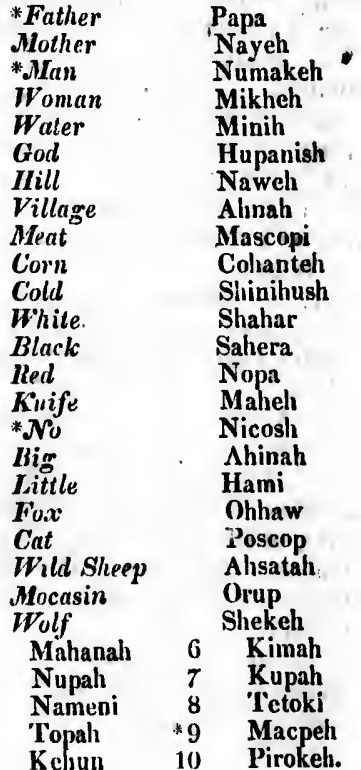

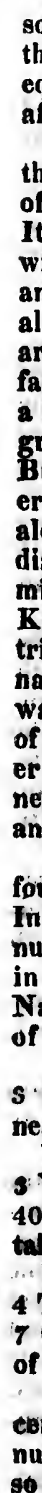


1.

independent hafinesque.

ANGUAGES.

Mandan.

3 of languages

and Clarke,

lo journey to

appear to have

pablished. It

put into the

Barton, who

cm; since his appeared, and ny whero

ton, $\mathbf{K y}$. Mr. who was one of Lewis in that furnished me tho Mandans souri, who le es Wahtanis, w scattered In rm the follow-

Papa
Nayeh
Numakeh
Mikheh
Minih
Hupanish
Naweh
Alnah
Mascopi
Cohanteh
Shinihush
Shahar
Sahera
Nopa
Maheh
Nicosh
Nhinah
Hami
Ohhaw
Poscop
Alsatah
Orup
Shekeh
Kimah
Kupah
\% Tetoki
9 Macpeh
Pirokeh.

The 4 words marked * have, or 20 per ct. in 1 Homai, 10 Pesome analogy with the English, kole; but they al'o very remote. through remote courses as usual, Mr. Catlin, who has visited equal to 12 per cent. of mutual the Mandans this year, 1832, affinity.

This language is totally new to Siposka-nukuki ineaning people the learned, it is found in rone of the pheasant! thus wo have 3 of the great philological works. names for this natiun, this is not It is stated by Lewis to differ unusual, each nation having mawidely from the Minitari, allies ny nicknames in N. America. and noiglibors of the Mandans, Ho says they are reduced to 1800 although a dialect of it; both souls, and that the Minitari are referred to the great Pakhi speak a dialect of the Upsaroka family of the Nortl,, themselves or Crow Indians.

a branch of tho Skereh or Panis group of nations and languages. But this surmiso appears to me erroneous, I can see but little an alogy with the Panis and Ricara fact that only 3 languages wem milarities with the Yancton anı met with in the Oregon mts and Konzas dialects of the Missourilcountry. 1 The Shoshonis in the tribes. The Wahtasuns or Ah-|mts, 2 Chopunislı from $m$ ts to the nahaways of Lewis, called Aya- falls of the Diegon or Columbla wahs by Slannon, are a branch $R$. 3 Chinuc from lience to the of the Otos and Ayowehs of Iow- Pacific Ocean. But they are spo. er Missouri, althongh settled ken in a multitude of dialects. near the Mandans, and speaking The Shoshoni is pretty well an akin dialect.

known to be a branch of the Alie-

The word mini for water is tan or WWestern Skereh, spoken found in all the Missouri tribes. as far as Mexico. The other two In comparing the 10 Mandan are less known. Mr. Sh. could numbers with the list of decimals only furnish me 12 words of in $50 \mathrm{~N}$. A. dialects in Tanner's Chopunish, a few mor'e met with Narrative, the greatest amount in Lewis and Cox cnable me to of analogies are found in the give 24 words of it.

Konza 1. Meakche, 2 Nonpal, 5 Sky 'Tetoh

s.Topali. Analogy nearly the same in Omawah.

Yancton 1 Wancliah, 2 Nounah Land Kaimo

5 Yahmeire, 4 Topal. Equal to †Father Pupa 40 per ct. the same in the Dako- Son Illim tSun Spokan

Minitari a Nohopah, 3 Nahme,

Nashne

Arme Tunashe

†rlead, top Chop

Flat Unish

('ut . Pakehuk

Broken Mutult

Iload Ahish

Buffaloe Cokala

Year of arialogy.

Wliile tlie Pani has only $10 \mathrm{p}$. cent of analogy by the single number 2 Patko. The Muscogih so far to the S. E. has even mure

Yahar 


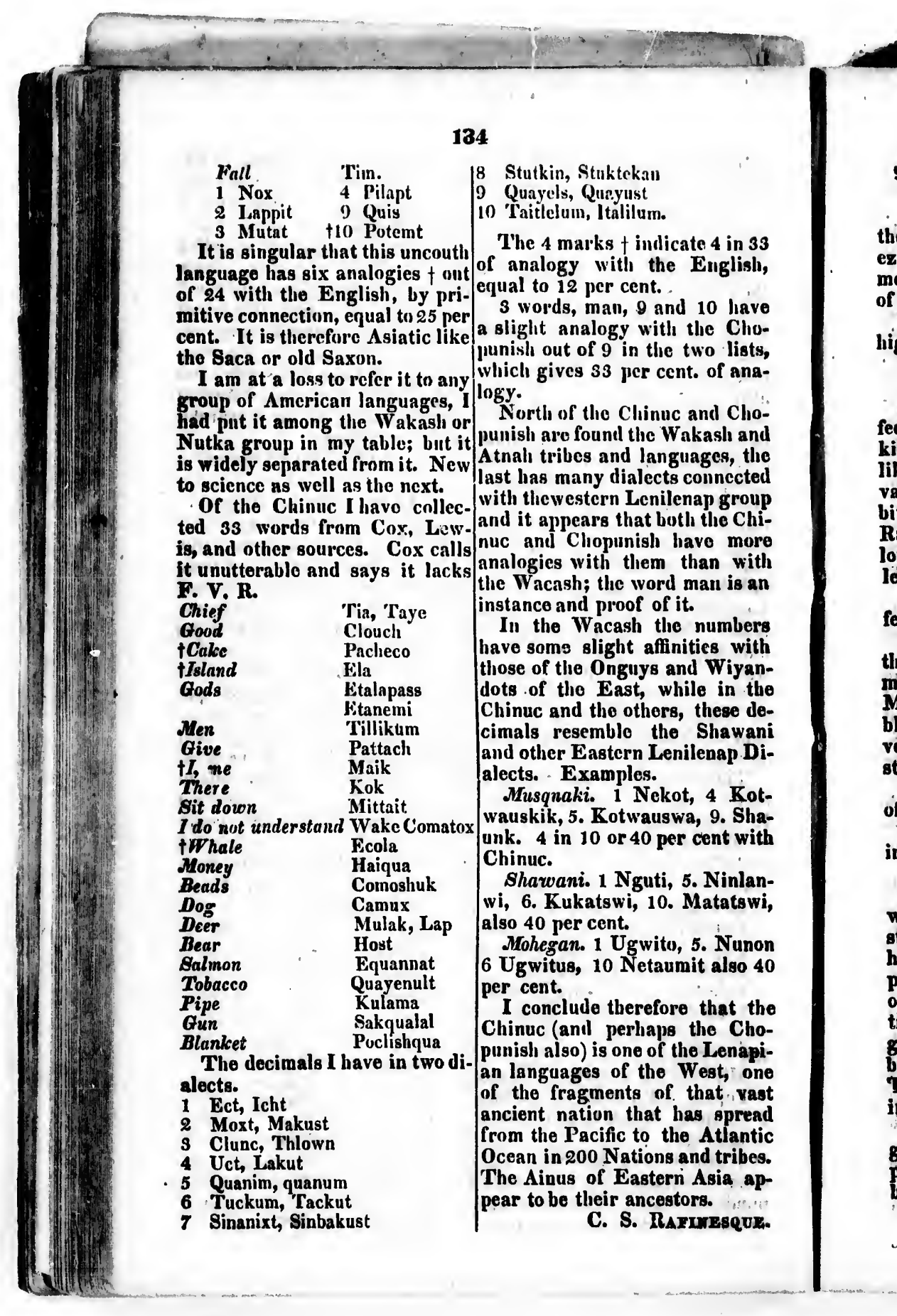


licate 4 in 33 he English, and 10 lave this the Clioie two lists, cent. of ana-

bic and Cho-

Wakasl and nguages, the cts connected ilenap group botli the Chihave more n than with rd man is an f it.

the numbers flinitics with and Wiyanwhile in the urs, these dehe Shawani senilenap Di-

kot, 4 KotIswa, 9. Shaper cent with

i, 5. Ninlan0. Matatswi,

to, 5. Nunon tumit also 40

ore that the os the Cho$f$ the Lenapi- West, one of that vast : has spread the Atlantic 18 and tribes. arn Asia apsstors. ATIMEBQUR.
99. Geulogical Remarks between Buffaloe in Nero York and Pittsburg, in Pennsylvania. Bx' Davin 'Thomas.

The following information on the cliffs of clay on which Natchez is situated was imparted to me this year by Dr. James Smitl of Baltimore.

a level rocky plainaloe creek, in ligh in 5 strata.

1. Soil 4 fect thick. Canada side whele it is more

2. Marly clay 80 feet thick. broken. The valley of Buffaloe

3. Bank of clay and shells 25 cr. is wille anil of yellow clay. feet; the shells are of several The shores of Lake Erie is Jow, kinds, chiefy a whito univalve of miry clay, mixt with sand and like Helix but larger, and a bi-gravel. Three miles from the valve, both soft not flinty. The creek the soil becomes firm, and bivalve is a new Diclisma. D.teres wells are dug under it in slate. Raf. Subcylindrical, 2 inclics The first bluff on the Lake is also long, fulvous, breadth $1-3 d$ of of this slate or argillite.

length.

At cightecn miles creek, a thin

4. Pure marly clay again 100 stratum of limestone, which once

feet thick.

5. Bank of 20 feet down to been broken into angular fragthe river shore, gravelly or clay ments with square edges to the mixt with rolled silicious pebbles. margin of the Lakc. The hills Many are of yellow Calcedony, of slate begin to become steep; black and red jasper, or some it is nearly black, resembling very curious stones, for in-coal, but in thin lamina, some stance.

Gravel stone with impression are iridescent, or a yellow subof wood on it! stance is found between the Red and yellowish chert with leaves.

impressions of shells. Beautiful pebbles decorate the Fragments of pumice stone. shore of the Lake, they are priBeautiful onyx pumice. Out- mitive fragments of many culors. ward coat like iron grey liorn- Springs of petrolcum are found stone, compact smooth without|a few miles inland, and coal holes, one line thick. Inside will perhaps be found hereafter. porose light with unequal holes, Muny bluffs project in the lake of a fine purple with shining vi- in deep water, yet it is said that trified specks. Next a band of formerly there was a passage or greenish and another rusty or/road at their fout, and that the brick color at the other end. lake has encroached there. PurThus this fine stone has 4 colors, plish ferruginous sand is found iron, purple, green, and rusty. on the shore between them. The

Fragments of pseudo volcanic bluffs are slaty and hardly 100 glass. One sumewhat like jas- feet high. Blocks of granite and per was grey inside but shining limestune of many tons are numeblack outside as if glazed. 


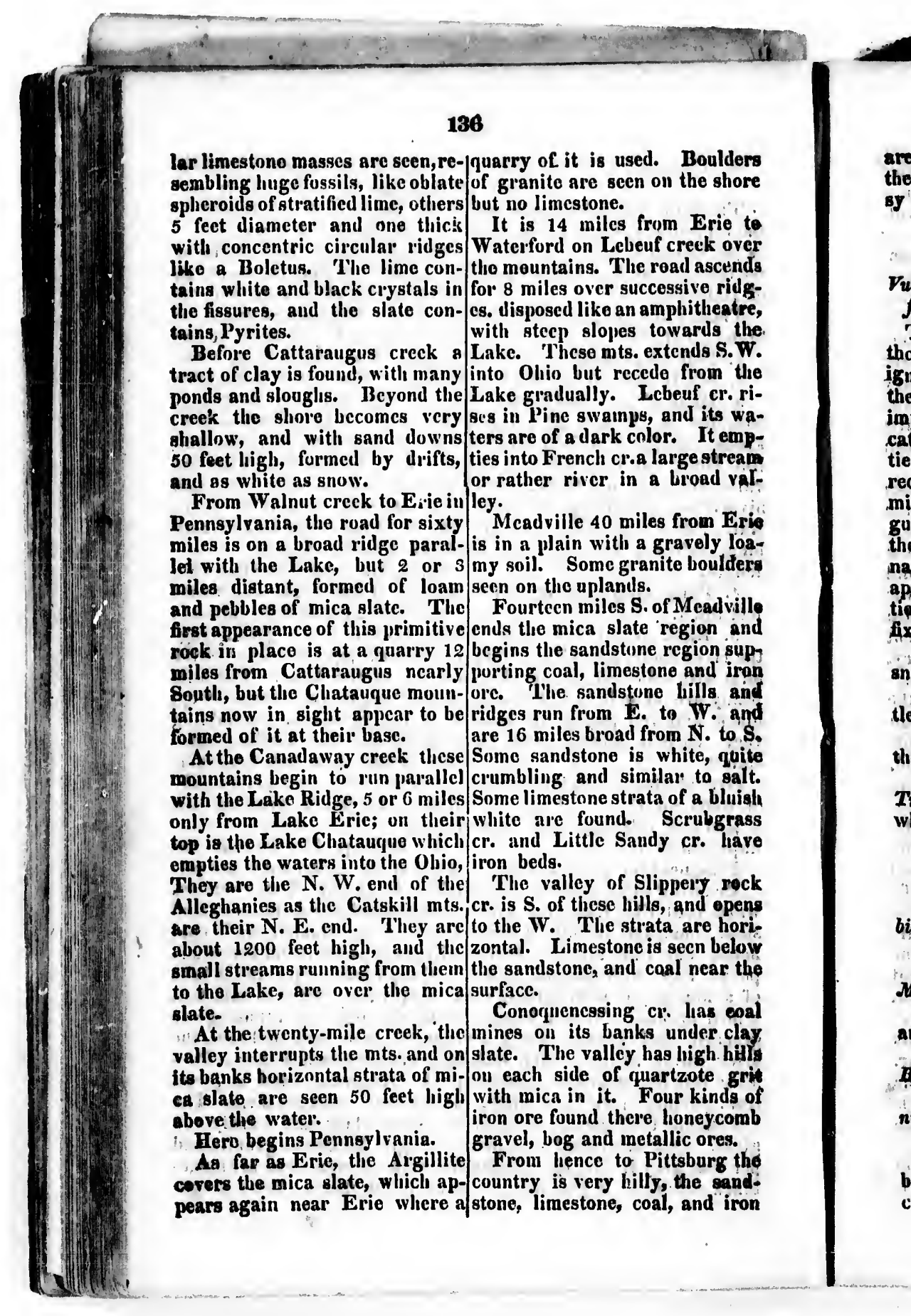


Boulders the shore

n Erie to reck over aul ascends ssive ridgphitlieatre, wards the ends S. W. from the euf cr. rind its wa- It emprge stream bi'oad val-

from Erio -avely loato boulder

Meadville egion and egion supand iron hills and W. and m N. to.S. hite, quite if: to sait. of a bluish icrulograss cr. have pery rock and opens are hori. seen below al near the Las eoal under clay high hills tzote gri ar kinds of oneycomb lic ores. tsburg the the eand. and iron are found every where, and on $P$. eyes or ringstones are $C \psi$ the top of each hill a kind of grca-- clurites.

sy ochraceous earth.

\section{ORYC'TOLOGY.}

P. stars or sca stars are Pentacrinites.

P. star's or star stones are Madreporites.

Vulgar names of fossils and petri- P. corals and thimble stones factions in North America. are Milleporites.

The common names given to P. almonds are Diclisma'and those objects by the illiterate and Nuculites.

ignorant of geology throughout P. lickory nuts are Pentremithe United States, are of some tes. importance, becausc they indi- P. acorns aro Cupulites. cate or lead to detect the locali- P. elk horns are Somarites. cate or lead to detect the locali- $P$. deer horns are Mazamites. rect the curious mistakes and $P$. snails and cockles are unimisnomers of the vulgar lan-valve shells.

misnomers of the vulgar lan- valve shells.
P. clans, muscles, oysters \&ce. guage on that scorc.

thercfore collected several of the alich I have thus seen $P$. tongucs are shark teeth.

$\mathbf{P}$. walnuts or balls are Bolac-
applied. The adjective appellaapplied. Petrified is commonly pre- tites.

fixed to all of them thus Pre sponges are Cavulites or Petrified snake, or coiled Spongites.

snakes are Ammonites. $P$. birds nests nro Antrosiles.

Rattle snakes or petrified rat- P. eggs or egg stones are Geotles are brthoceratites. dites.

Petrified fishes are the inside of P. fish roes are Oolites. the same.

Petrified crabs and beetles are tolites Trilobites, called snake heads P. nets are Tesselites.

$\begin{array}{ll}\text { P. turtles are Septaria. } & \text { P. sliecp's liorns are Spimulites. }\end{array}$

P. butterflies are Productus. P. needles aro Spinulites.

P. buttertics are Productus.
P. wasu nests are Favosites.

P. buffaloe horns are large Tur spines of Echinites.

binolites.

P. $\log$ teeth are T. cynodon. P. chains are Catenularia.

P. giants bones anil teeth are C. S. R. Mastodon and clephants.

P. men's heads aro Nodulites 101. Ancient Volcanoes of and Pithecites.

P. knives or bills or penis are Belemuites. and bark are Alcyo- the theoretical doctrines of Eunites.

ropean Geologists, and so will

P. screws are Encrinites. P. The highest mts. were said to buttons the same when the arti- be of granit every where; but culations are loose. the lighest in the world, those of

Nonth AMEhica.-Bx C. S. RaFinesque. 
South America ate of Porphiry, Volncy was the first to call Lake those of Central Asin still highier Ontario a volcanoe! and to notice are of stratified primitivo rocks our ancient mountain lakes now jumbled like marble papel.

dricd up, by eruptions or convul-

The grcat geoiogical question sions, cach having a breach or of the igneous or arueous origine water gap. I am induced to amof the globe and the primitire plify his views by deeming nearformations is now pretty much at ly all our lakes, as many volcanic rest. It is become more impor- outlets, which have not merely. iant to ascertain the origine of thrown waters in later periods the secoudary formations, with but in more ancient periods have their immeuse stores of lifo and formed nearly all our secondary organic remains, thercin entomb- strata by cruptions of muddy waed. ter, mud, clay, liquid coal, basalts

The theorists once sustained trap. 'I'his was when the ocean that all the limestone had been covered yet the land.

made up of shells by compression Submarine or oceanic volcanoes although we have primitive and cxist as yet every where in the volcanic limestone without shells. ocean, \& their effects are known. Now they maintain that all the They must of course be hollow coal formations are made up of outlets under water, that would wool by compression, because the become lakes if the ocean was lignite is thus formed, but thic pri- dried up. Wo can form an idea mitive and volcanic anthracite of their large number and extent and bitumito without any trace by the late but natural discovery, of wood upsets this theory also. that all the Lagoon lds, and clir-

No one cau be a good geologist cular clusters of Islands in the without having seen volcanoses, Atlantic, Pacific, and Indian or at least without having studied oceans aro volcanic craters! This well their actual operations is now admitted even in England, throughout the globe. After see- and the coral reef often crowning ing the liugo volcanoes of Suuth those cluster's are later superinAmerica throwing yet streams of cumbent formations by animals. water, mud, clay, sand, marl, bi-Tho Bahama Ids in the Atlantic, tumite, pichstone, \&c. instead of the Maldives near India, and melted stones, whilo the same the Coral Ids. all over the Pacific happens also in Java, Spain, $\mathrm{Si}$ - aro the most striking of these cily, Russia....Humboldt could singular volcanic clusters, nearwell account for many ancient ge- ly at a level with the ocean. Some ological plienomena, and he was of tl.em are of immense extent even led to surmise that the great from $60 t_{1}, 150$ miles in circuit, Asiatic flood was caused by a vol-- or even more.

canic eruption of waters from the Some circular bays and gulfs Caspian Sea. If this should be of the sea appear to be similar, corfirmed by inspections, we may differing by having only one well surmiso that our great flood breach. The bay of Naples is of North America, tracell by our one also, an ancient crater, with diluvial formations, was also can- islands in front.

sed by eruptions from our great The analogy between lakes and Northern Lakes. volcanic craters is obvious. Al- 
o call Lake nd to notice lakes now or convulbreach or uced to amming near. ny volcanic not merely er periods riods have secondary muddy wa. oal, basalts $n$ the ocean

c volcanoes lere in the are known. be hollow that would ocean was rm an idea and extent I discovery, ds, and cirinds in the nd Indian aters! This n England, n crowning er superiny animals. 1e Atlantic, India, and - the Pacific If of these sters, near cean. Some nso extent in circuit, and gulfs be similar, only ono Naples is rater, with n lakes and vious. Al. \\ 13}

most all ary craters become laikes i, 'To trace all these formatipns Alled with water, when thoir ig- to, their sonrces, delineato their noous activity is spent. All surings are smaller out- ages und ravage on organized lots of viater, while the fuma- beingw, will require time, ansidurolos and holes of igneous volca- ity, zeal, and accurate observanoes, aro small outlets of amoke th fire, air, gazes, hot mud, \&c. I What connection there is be can jerccive no essential difro- tween lakes ordry basins of primirence between them or any other tive regions, and their formations oruptivo basin, excopt in the de- is not woll ascertained. Some gree of caloric or kind of mat- are evidently the produce of cryster which thoy emit. They may tallization; but others forming both be quiescent or in activity. streams, veins, banks and ridges Springs vary as mucli as rolca- may liavo bcen ejected in a fluid noes. We have feiv puro springs ir soft state before organic lifo they commonly hold mineral sub- had begun, and thus spread jutto stances? they are cold, warm, their actual slıpes. Many hot, salt, bitter, saline, bitumi- streams of primitive limestone, nous, limpid, colored, muddy; anthracite wake, guit-are properpetual or periodical, flowing bably ac formed and expanded. or spouting. Just like volcanic Hollows in the primitive, acean outlots. must have been the outlets of Therefore volcanoes are pru- theso substances, now become perly igneous springs, and lakes after the land becamie dry. springs or lakes are aqueous vol- The pewer which rises and canoes! ejects out of the bowels of the Under this viow, we bave no earth, watery, muddy and oolid lack of volcanic outlots in North substancos, either cold or inAmerica, since one half of it, the flamed is ono of the secrets of nawhole boreal portion, from New ture; but we know that such England and Labiador in tho power or cause exists, sinco wo Fast, to North Oregon and Alas- seo it in operation. Water rises k2 in the West, and from Lake in lakes and springs much aboro Erie to the boreal ocean, is filled the level of the ocean, while tho with them, being eminently a re- Caspian sea is under that level. gion of lakes and springs: cov- There is then no uniform lovel ered with 10,000 lakes at least. for water on the globe, nor uni-

To these as well as to the diry form aerial prossure over them. lakes of our mountains, tho limo-Another causo operates within stone craters and ginks-may be the bowels of the earth to genetraced as the original outlets of rate and expel liquid and solid our secondary formations, in a substances, porhaps many causes liquid state under the ocean, im- and powers are combined there. bediling our fossils. The basal- Galvanism is probably onie of the tic trapic and carbonic forma- main agents. A living power of tions have the same origine, since organic circulation, would cxthey are intermingled. But some plain many earthly phenomena. kinds of sands and clays liave Tho great astronomer Kepler been ejected since this continent and other philosophers; surmised becamo dry land. $\quad$ that tho earth was a grcat living 


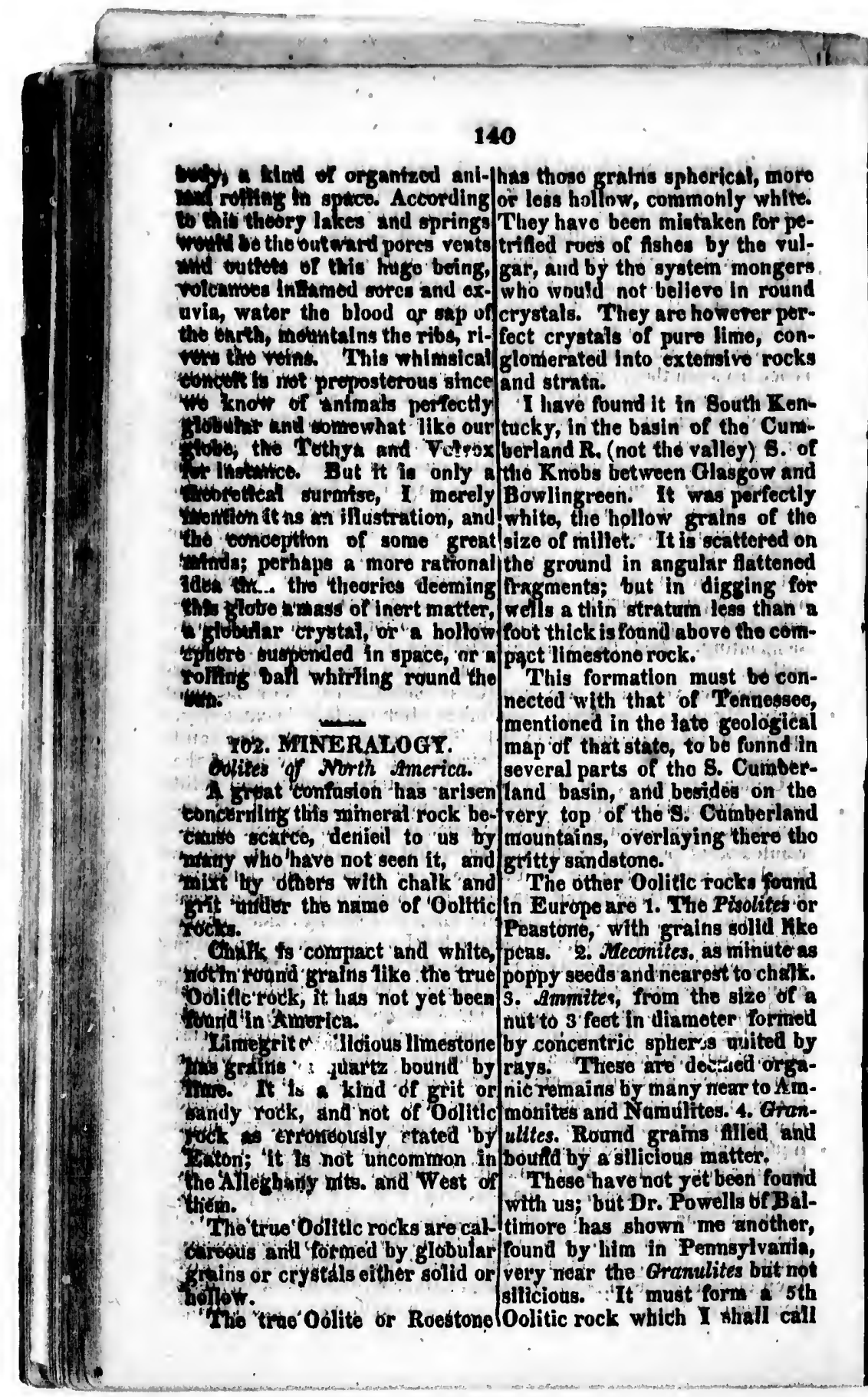


ical, moro ils white. :en for pe$y$ the vulmongers in round vever porine, conive rocks outh Kenthe Cuntloy) 8. of asgow and periectly ins of the affered on s flattenod gring for eas than' o the com-

st bo conTonnossee, geolöjlcal - funnd In Cumberes on the timberland 5 there tho

ocks found Pxolites or i solid Rike i minute as it to chalf. size of a or toritivet nuited by vied orgthear to $\mathrm{Am}$. 1.4. Granfilled and atter.

seon found dls of Bal- another, nsyivariia, tes brit not in 5 th thall call
Pantolices or Poweletone. It ia/aion, and Lako Erio and othen, grey fillod with minuto bluish lakes, the Atlantic Qcenn de. round oolitic spots not larger In Auguat 18s1, in my ans than millet, theso round graing Zoological letter to Curler od are solid: the general fracturo ia nories, I informed him that wa. angular as uswal. It occurs near had about 1000 spocice of libes Milton above the Red Shale, in in our atreams and lakes of which large nodular masses in place, 700 arn yot undescribed, and and also nisar Easton but in frag- determined their statlons as foln mente out of place probably di- lows, dividing them into $10 \mathrm{lch}$ Juvial. Dr. Powell thought this thyological regions of freah wathe true Oolite, iut it is quite dif- ter, each having a peculiar geneforent from it. ration of Ann t tribes.

Oolites are also indicated as 1. Regino. Of the Gmet Likes found in New Jersey, New Xork|St.Lawroace \& allmantetrinas. and Ohio, but unless properly 2. North Atlontie itrion, described it is not possible to from Malpo to the Chacents, aver which kind is meant.

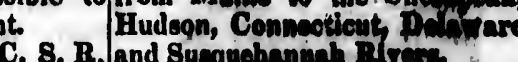

3. Bouth Atlantion thin the

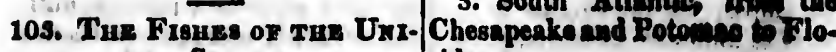
rida.

Many aplendid works have 4. Floride atrename and Inkea. been published on our birds; but 6. Moxican gulf, drums and none yet on our beautiful and rivers of Alabaing

valuable fishes. I havolo:'g had 6. Loniniane or Iown Mlicin contemplation a general histo- sissippi, Red R. Artsanaes ac. ry of uur finny tribes, after do- 7. Obio and branchen. Trancescribing $100 \mathrm{~N}$. Sp. of fish in the sec, Cumbortand, ecc.

single river Ohio; but such works 8. Uppar Minaledpeh Inimole, are not yet sufficiently patroni-land branches.

zed Lesueur. who had collected 9. Missouri \& afillnont wtrame. 0 many beautiful drawings of 10, Region of Oregon, in the cur lake fishes, has never been $\mathbf{R}$. Oregon and branches. able to publish them. Dr. De- All these Regions have each at kay of Now York once told me least 150 species of fistes, and that be liad begun a natural his-deducting 1-Sd from each for tory of cur fishos, which has those fer common to severnal ro. never appeared. I am told that gions, $1000 \mathrm{sp}$. will remain in the Dr. Holbrook of Charleston is whole. The regions 4, 3, 6, and writing the history of our South- 10 , are entirely unexplored by ern fishesh Much remains to be scienco.

done in this branch of Natural To these 10 regions of frees History, and to prove it, it will water fishes, we must add threo we auficient to etate that I have regiuns for sea fishes.

discovered and figured already 1. Atlantic Region.

800 N.Sp and many new gemera 2. Southern Region.

of finen frem the river Ohio and 3. Mexican gulf.

branches, Misaiesippi; Potomac, Each must afiord 200 or $\$ 00$ Susegehannab, Delazare, Hud-|sp. many of which mugt bo now, 


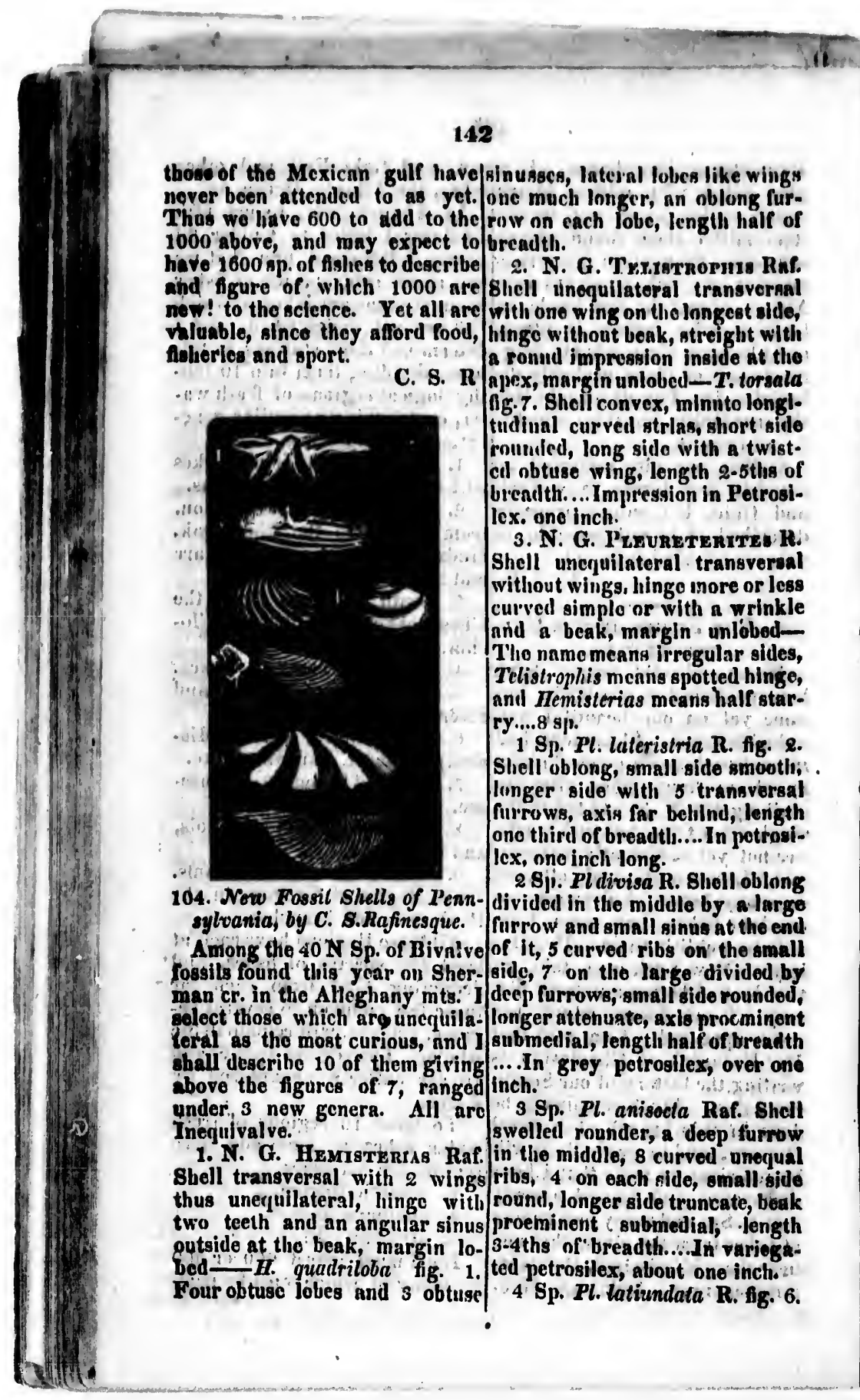

Slicl

or 4

flext

larg

6

long

hing

equa

of $b$ near

Shel

Shel
with

or, w

Jong

inch

$\therefore 7$

She

stris

rour

…I

oval

obli

side

pros

silos

ap.

not

105.

$\mathbf{T}$

poly

are

whe

latel

bilic

Bas

sites

top

equi

eacl

Ver

gen 
wings ing furhalf of

11. Rne.

avoraal

est slde,

fint with

e at tho

torala

- longi-

ort side

a twist-

- 5this of

Potrosi-

TTES $\mathrm{h}$

nsverual

e or lese

vrinkle

llobed-

ar sides,

a hinge,

alf star-

fig. 8 .

smootli:

insversal

1; Iength

potrosi-

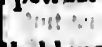

Il oblong

a large

to the end

he small

vided by

counded,

ceminent

foreadth

over one

thatitis.

f. Shell

if furrow

unequal

iall side

ate, beak

- length

Parieg

inch.:

R. fig. 6.

\section{0}

Sliell ohlong both ends obtuse, 3 the internul structure of Milleor 4 broad wared ribs, margin pore tribe.

Alexuose, benk aulimedial, length Bp. Strutipori brectissioma Raf. 2-5th of breadth.... With the Inst Basultic pillars not striated comlarger. monly liexagoni, 2 opposite siden 5 Sp. Pl. striuta R. Shell ob- longer, even st top, but unequal long, swelled both sides rounded, in jength beneath, forming an linge floxunse by nrched benk, extended fluttened level mass. equal longitudimai strias flurougiı- From Ionisiana near the River out, beak submediul, length lialr|T'eche, spreciuen 4 inches by 3 , of breadth..:In white sandstone, pillars from 1.4 to 1-2 linching nearly two inches. only, of a giecyislı color, inarly

$6 \mathrm{Sp}$. Pl. bifasciata R. fig. 4. smelling of cliny but very haril, Sliell roundel swelled, smooth ceded to me by Professor Green, with two falnt transvel'sal bands who decmed it wrongly a T'ubior wrinkles, beak round Interal, pore.

longth 2-3ds of bicendth...In yel- \&. Fiexurites Raf. Body low sandstonc, small, half an fixed obconic, outside will a inch.

thin tegument covered with flex-

$7 \mathrm{Sp}$. Pl. concentrica R. fig. 5. Hose wrinkles, inside solid flied Shell ova:, minute concentric with minuto transversal flexuose strian, beak obtuse ut $1-3$, sicles fibres or strias.... Another very rounded, length $2.3 \mathrm{ds}$ of breadth singular and anomalous $\mathbf{N}$ : $\mathbf{G}$. ..... In petro?ilex. . akin to the Madreporites, but no 8 Sp. Pl. obliqua R. fig. 3. Slicll stellatel mputl, insile not radioval oblique swelled; 8 curved ated, but irregularly flexviose. oblique furrows, 3 antl 4 on the Perhaps it is a fossil Porostome sides of the iniddle one, beak or animal without month as Teproeminent at 1-3, length 2-3 of thya, \&c.

breadth.... In grey clicrt or petro- Sp. Flexulites haydeni Raf. silox, small half an inch, near to Body obconical truncate, subagaj. 3, but lese decply furrowed regate, outside flexules transvernot truncato belind. "sal, each ralscil and with a fur220 row on it internal ficxiles 105. Stratipora axd Frexu- termixt becoming less near tho IITEs N. G. surface.... Specimen 4 inches long

These are two N. G. of fossil clianged into a silicious grey polypites of my. cabinct. Both slate, upon a rusty slate, from are from the fine fossil regions the region south of the Apalachisouth of the Apalachian mts. an in Alahama. Ceded to me where so many new shells liavo by Mr. Hayden to whom I have lately been found. They are not dedicated the sp. $\quad$ C. S. R. ilicified.

1. Stratipora Raf. Mass of 106. New Lizarn from KenBasaltic angular cells like Favo- Tucrr.

sites, but short not concamerated, It was observed in 1823, on top with several regullar rows of the Knobhills of West Kentucky equal round pores like Miliepore not far from the Mammoth cave. eacl corresponding to a tube.... It is called scorpion and errone. Very singular $\mathbf{N}$. G. with the ously deemed poisonous, like general form of Favosite, and most of our Lizards. It is ra- 


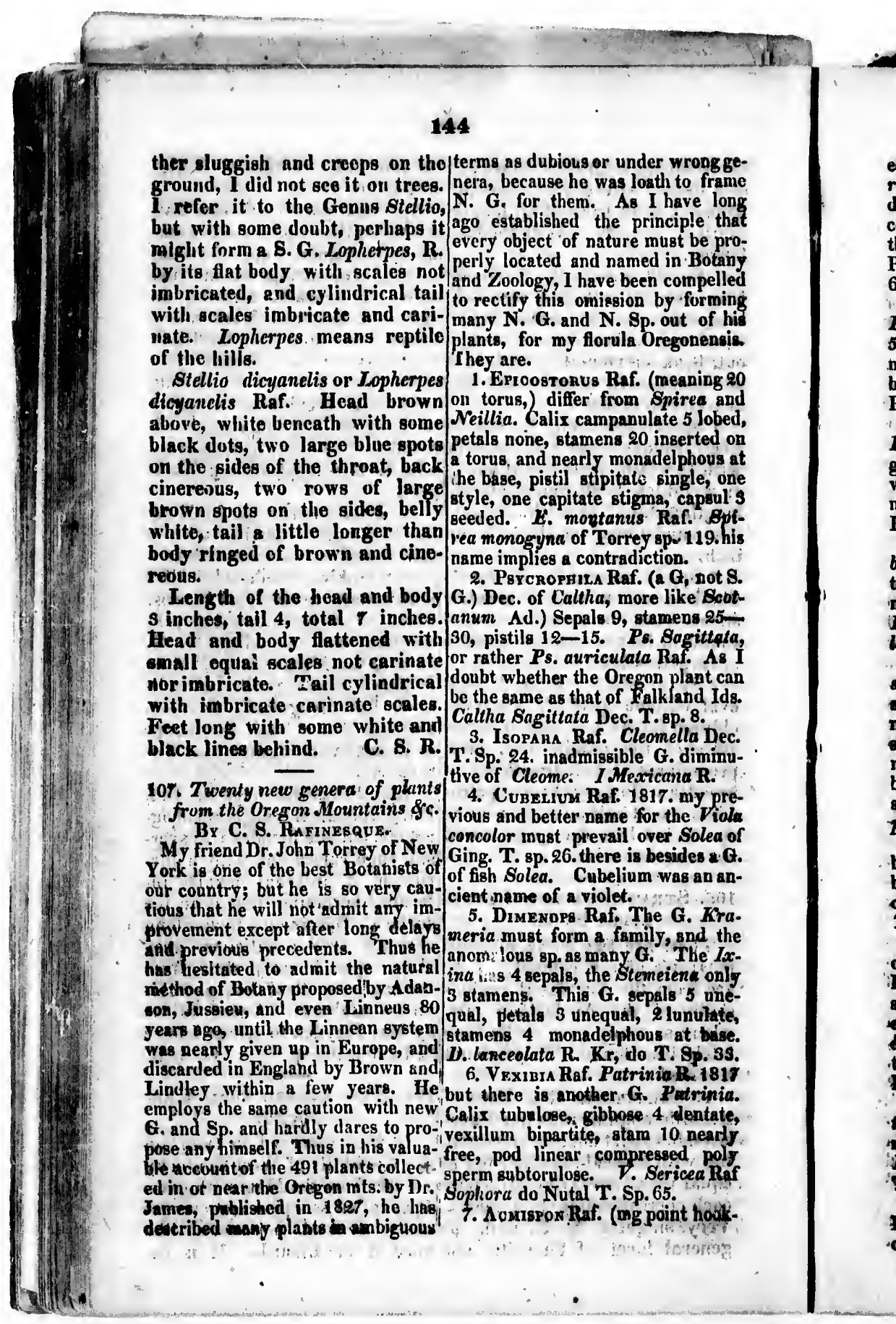




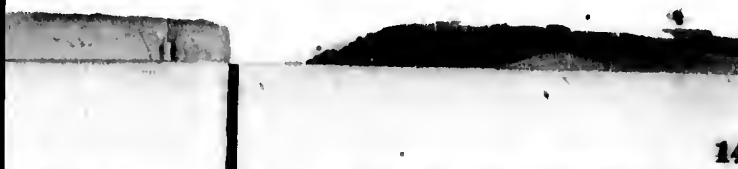

er wrongge-

th to frame

I have long inciple ths nust be pro.

d in Botany compelled by formin - out of his regonensis.

(meaning 20 Spirea and ate 5 lobed. inserted on delphous at single, one ha, capsul's Raf. Bpt-

sp. 119. his tion.

(a G, not $\mathrm{S}$.

- like Ecot-

amens 25 -

Sagittqta.

Raf. As I

in plant can

lkland Ids.

8p. 8.

mella Dec.

G. diminu-

icana R.:

17. my pre-

$r$ the Viola

er Solea of

vesides a $G$.

was an an-

e G. Kra.

ly, and the

The Ix.

reiene only.

ils 5 une-
¿ lunute.

at báse.

T. Sp. 33.

Iia. 1817

Patrinia.

4 dentate,

10. neardy

seed poly

vericea Raf

65.

145

ed) Difier from Trigonella, Duce-|tire yellow. Antheras mutic, style rates and Platycarpos. Calix large glandular, stignin bilobe. Beeds deeply cleft, pod stipitate, straight smooth 5 toothed. Phoranthe naked. compressed, swelled and hooked at St. angustifolius R. Pectis 'P. 228 . the point "A. sericeus R. Lotus do 16. Butuntress Raf. (mg amiable P. Trigonella Americana N.'T. Sp. flower) Dif. Cantua. Calix 5 gon. 5 69.

flower) Dif. Cantua. Calix 5 gon. 5
fid. Corolla hypocrateriform s lobed

8. Jamesia Raf. differs from entire. Stamens 5 unequal incluse. Psoralea, calix not glandular, hairy, Style filiform, stigma trifid. Cap5 subulate clefts nearly equal, sta- sule 3 locular, 3 valve polyspermous mens monadelphous, pod acuminate seeds angular. $1 \mathrm{~B}$. agregata $2 \mathrm{~B}$. by style; stigma smooth. J.obovata longiflora $3 B$. pungens Raf. CanRaf. Psoralea jamessi T. Sp.75. tua Sp. Pursh and Torrey.

9. Orbexilum Raf. differs from 17. Quincula Raf. Dif. Physalis. Psoralea, calix campanulate not Corolla campanulate 5 lobed, with glandular, emooth, teeth ciliate, 5 opaque spots. Capsules 3 celled 3 vexillum rounded expanded (sta-seeded. Q. lobata R. Physalis do mens diadelphous.) O. latifulia Raf. T. 302.

PB. do T. Sp. 76. 10. Physompra Raf. differ Oro-tostemon. Calix 5 leaved equal imbus, Phaca and Psorclee. pod stipi- bricate. Cor. bilabiate tubular, uptate swelled membranaccous, 12 re--per lip bilobe, lower trilobe. . Staniform seeds. 1 Ph. lonmifolia. 2. mens smucth, sterile filament smooth Ph. dispar R. Orobus N. T. Psora-jobtuge shrubby. I. purpureum R. lea Pursh.

11. Dasiogrna Raf. differs Pro- 19. Ozodyous Raf. (mg fetid sopis. Cal. camp. 4 dent. Petals 5 gourd) Monoical, perigone campacubequal. Stamens 10 free decli- nul. rugose, 5 external subulatc teeth. nate subequal, (hypogynous!) Pistil Stamens 3 monadelphous singenesris atipitate villose, style filiform, stig- stigmas 3 bipartite. Fruit glolular ma simple. Pod linear compressed smooth 4 celled, partitions spongy. bivalve torulose, pulpy within 12 Seeds on double rows oval smooth, bivalve torulose, pulpy within 12 Seeds on double rows oval smooth, pis. T. Ip. 110.

margin acute. O. perennis Raf. Cu-

12. Oreotres Raf. Dif. Tiarella 20. Funezonia Raf. Perigone 6 by 5 stameris only, from Heuchera sepals, 3 external trinerve, 3 interby 2 styles, cal. camp. equal, capsul nal narrower enerve. Stamens 6 coalescent at base. 0 . bractsata $R$. equal, filaments linear.narrow smooth Tiarella do I. J. 168.

13. Onzoxis Rif. Umbel invol tusely triaugular, style clavate subo, partial 5-5 phyllous, linear. triangular, stigmai capitate trilobe. Nlowers polyg. mixed. Calix 5 teeth Scape bracteate uniflare. 1 F. subulate, petals 5 yellow equal acute, bracteata Raf. Ornithogalum do T. and incnrved. Stamens and styles 443, very different Genus.

divaricate, pistil orate sulcate, fruit I sent an account of many of those tricostate on the back. O. humilis N.G. to Decandolle in 1830. I wish Raf. Anomymo! T. J. 179.

14. Prtonia Raf. Dif. Prenan- forming and naming these N. G. himthes by rappus sessile, plumose, pe-self or making iS. G. of them; but tianthe'sflore 1 Pt. pauciflora. 2. now I hope he will nothesitate many IIt. tentrifolia R. Prenanthes do years to adopt them.

He has done the sarne with 9 doubt-

15. Hesceseos Raf. Dif. Pectis, ful sp. throughout this otherwise Perianthe campanulate 8 phyllous, clever labor; he has however several corivoevis. Thes 7 or 8 oblong en-lnew ones, but not a single N. G. Ha- 


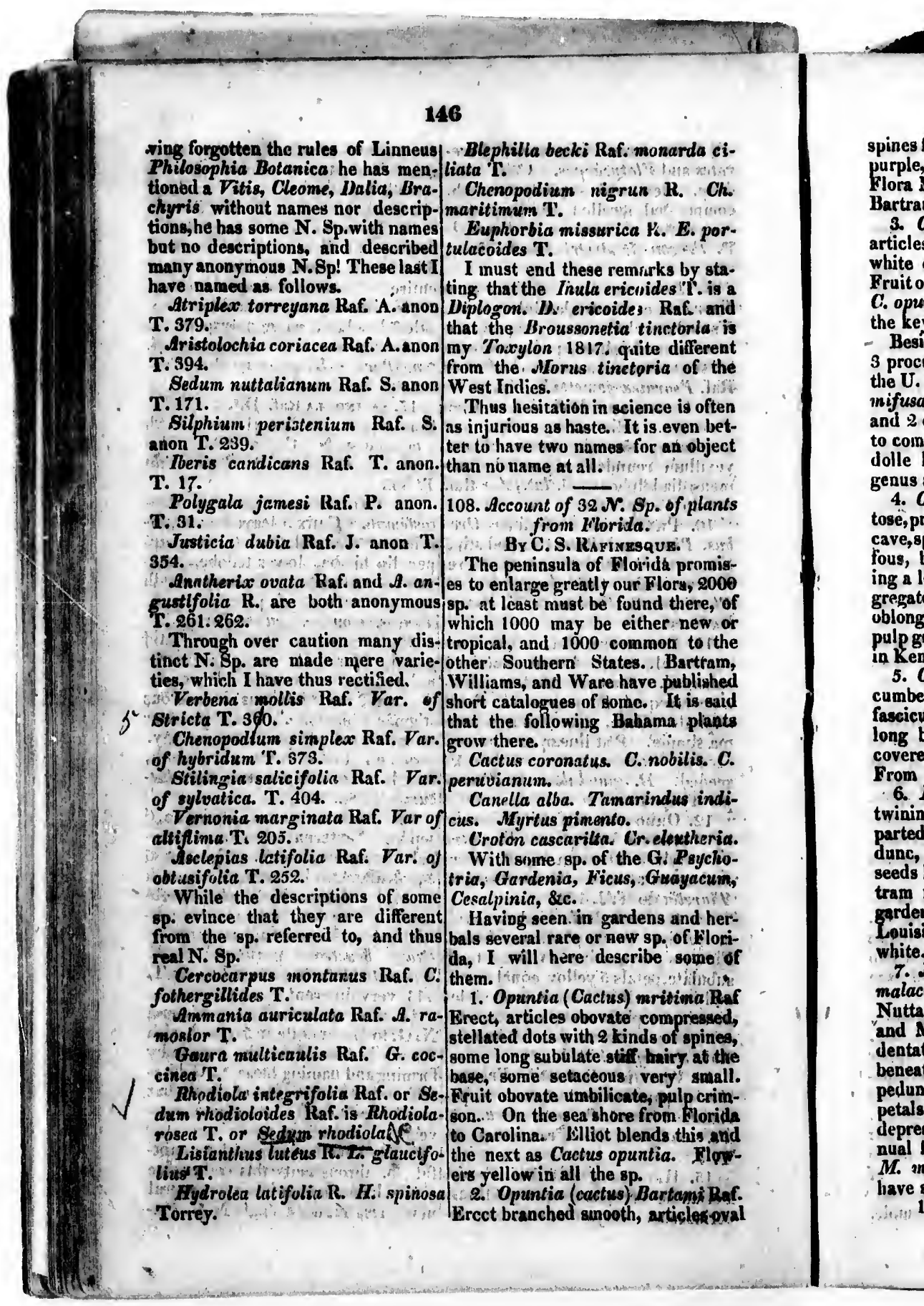




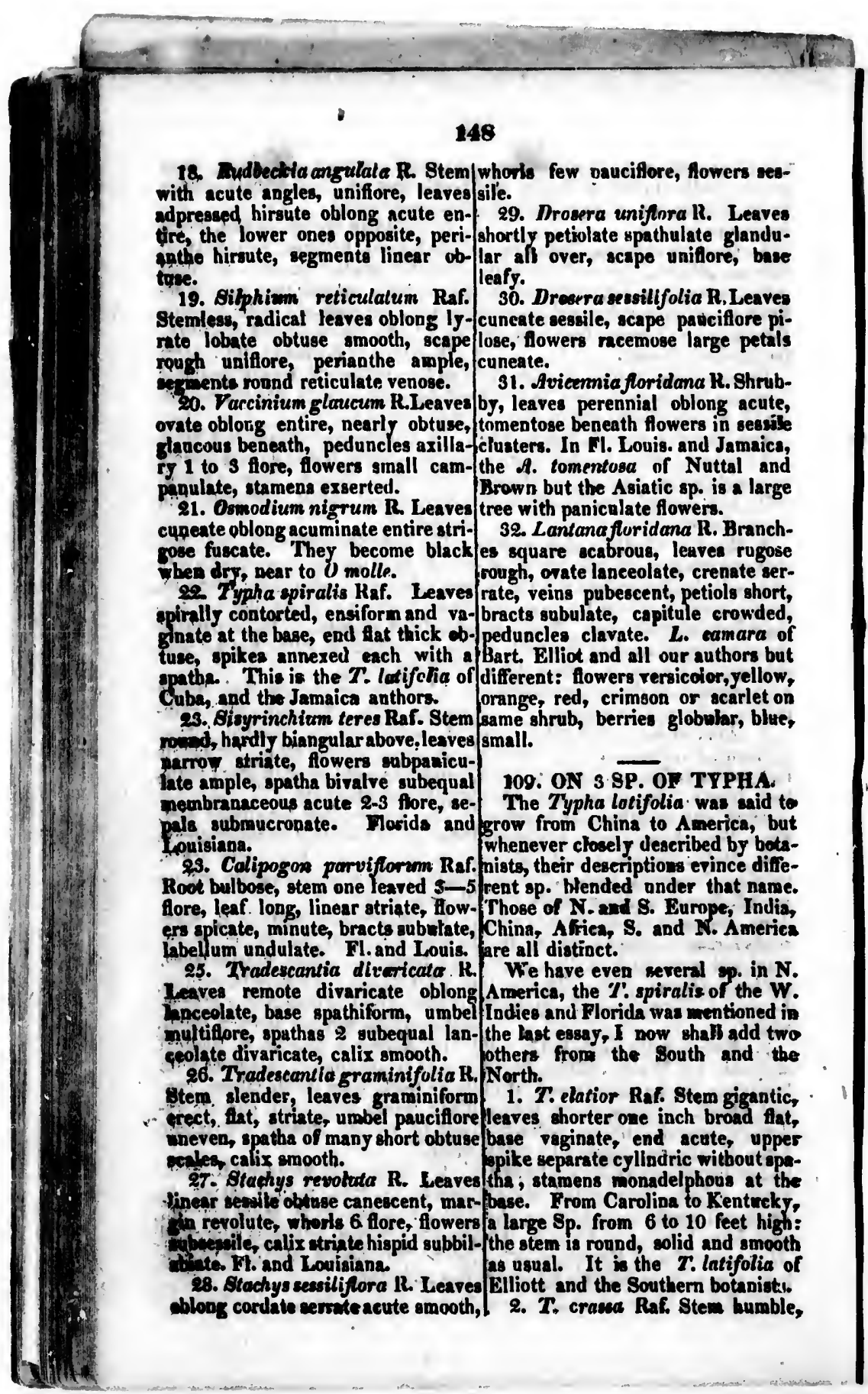

foliose

meath

obtuse

upper

ducou

brana

North

4 feet

one in

very

Anoth

110. I

LIF,

The

discov

is near

leaves

near

leaves

inear

Calix

base $w$

pit, en

inside.

subses

small.

lous:

folioles

dichot

entire

Ori

Slifor

ed, 16

acute,

tuse $t$

umbel

qual,

In

Kenty

ens w

lucre.

by the

of the

neric

2.

4-5 pl 


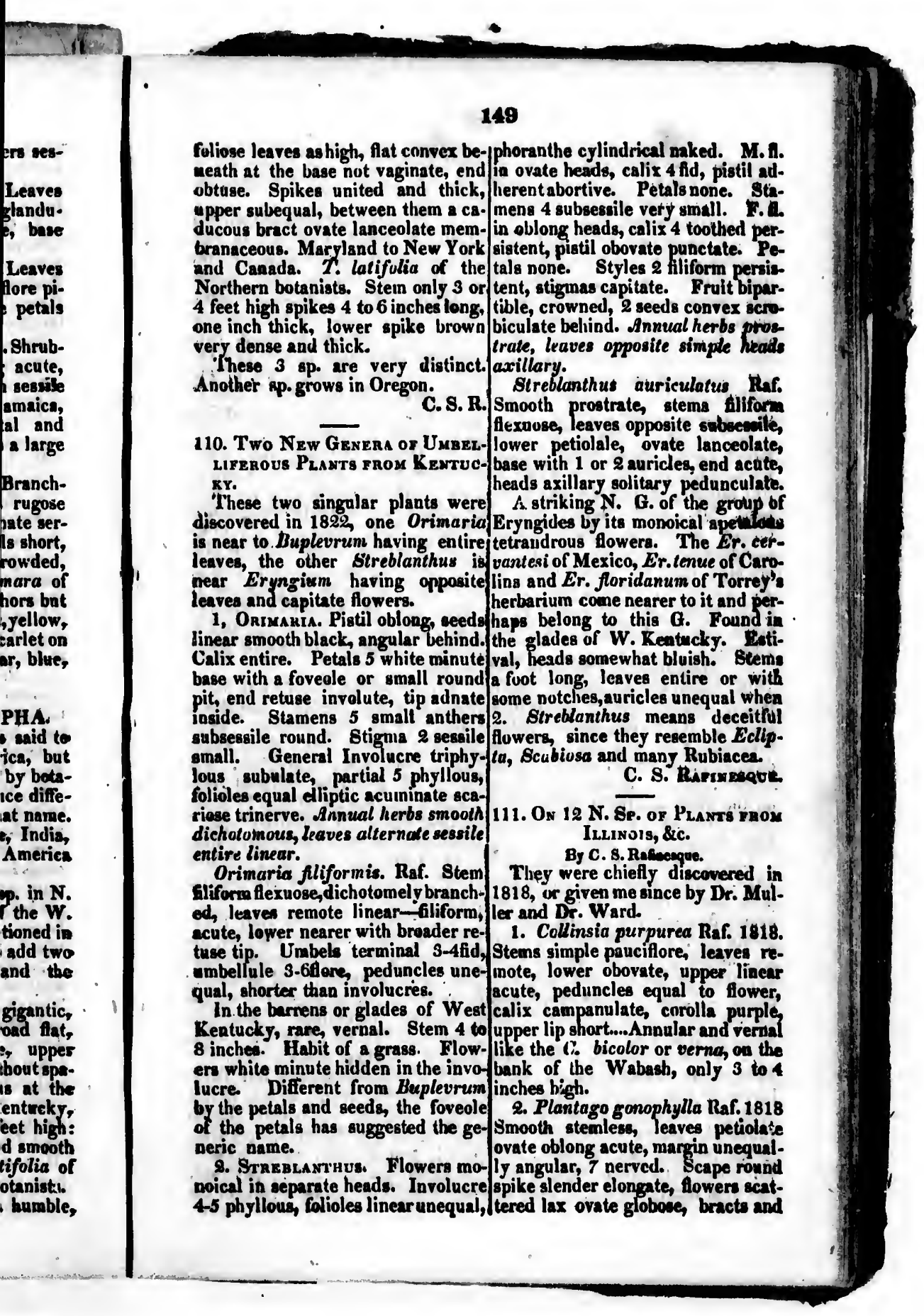




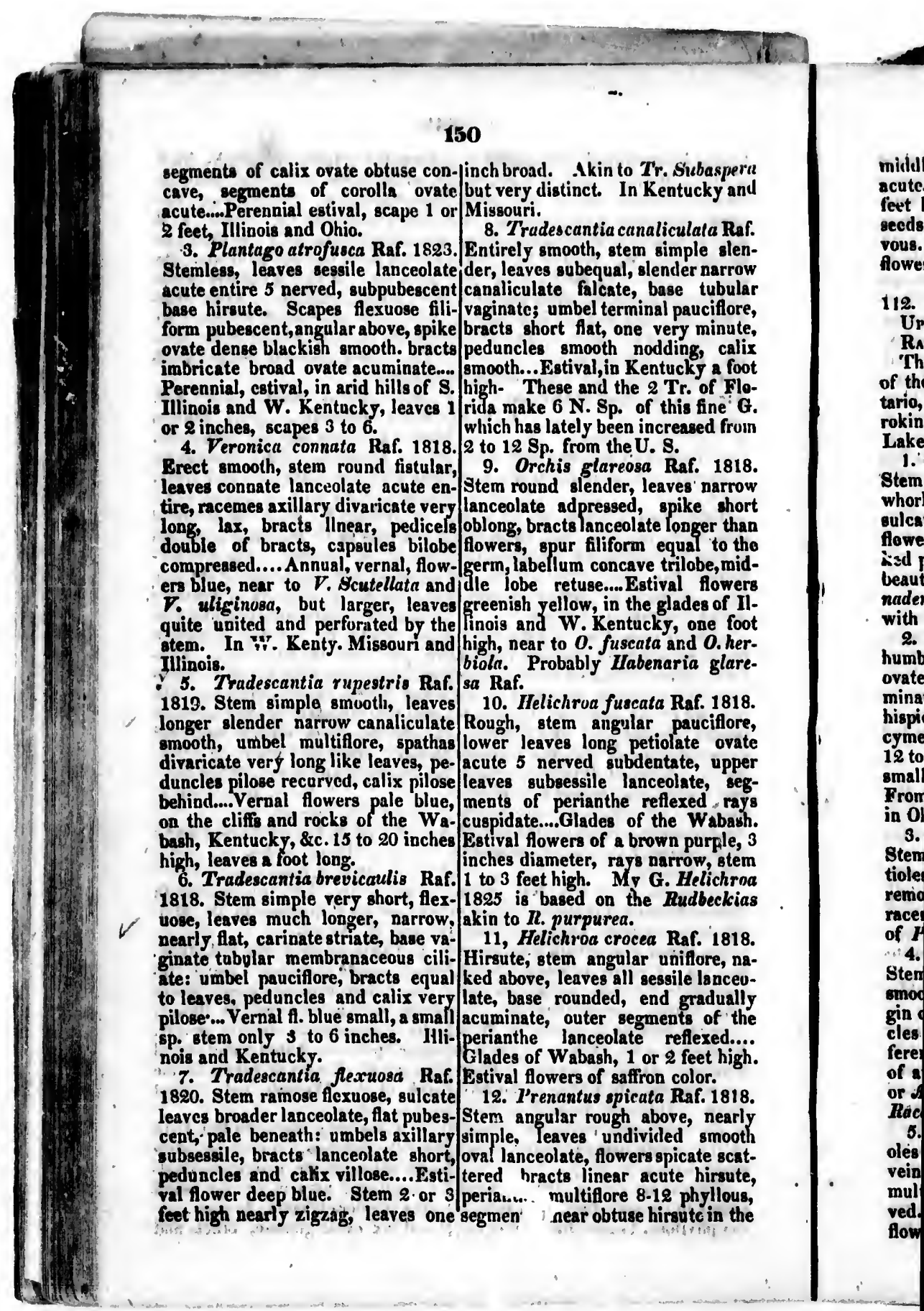




\section{1}

midllle, calicule hirsute Innceolate 6. Iysimnchin ('T'ridynia) sessili: acutc....Glades Illinois and Ohio, 2 folia Raf. Icaves opposite seasile feet high, estival fl. ochroleucous, uvate lanccolate obtuse, punctate, seeds compressed oboval pappus ful-pale beneath, flowers opposite or vous. Near to Pr. rucemusu, but whorled, peduncles short, petals en flowers sessile. tire.... Near to $\mathbf{L}$. revoluta. Flowers 112. ON 17 N. Sp. of Prasts mom ycllow with 5 unequal nionadelphous

Utper Canada, \&c. hy C. S. nia.

RAFINEsque.

They are chiefly from the islands Dioical, leaves biternate, folivles of the St. Lawrence, near Lake On- ovute acute entire smouth, pale betario, seen in the herbal of Mr. Ha- neath, terminal petiolate subcordate rokins in 1816, or collected near trifid, panicle terminal pauciflore, Lake Erie and Niagara falls in 1826. filaments filiform... Near to $T h$. dioi-

1.' Cornus cyananthus $\mathrm{Kaf}$. 1816. cum, but different, stem 15 to 18 Stem herbaceous angular, leaves 6 inches flowers white estival. On L. whorled sessile obovate acuminate, Ontario, \&c.

sulcate above, glaucous beneath, 8. Arenaria flexussa Raf. Stem flowers blue capitate subcymose na. flexuose subramose erect, $2-4$ flore, isd pedunculate, berries oblong.. A leaves ovate oblong acute trinerve beautiful atriking sp. near to $\boldsymbol{C}$. ca- pubescent, flowers terminal, pedunnadensis, same size, but flowers blue cles long, segments of calix ovate with a long style: very rare.

2. Cornns suffruticosus Raf. Stem ands, small $\mathrm{fl}$. white, very different humble shrubby, leaves petiolate from $A$. laterifiora.

ovate, base acute, end obtusely acu- 9. Aremaria connata Raf. Stem minate, margin cartilaginous, above erect aimple slender biflore, leaves hispidule, beneath smooth glaucous, connate cuneate oblong pubescent cymes pedunculate. A small shrub acute, flowers apetalous, cal. seg12 to 20 inches high, with red twigs, ments lanceolate....The apetalous sp. small leaves, white flowers estival. of this G. must form a S. G. MoniFrom Lake Champlain to Lake Erie lix.

in Ohio.

10. Orchis (Platanthera) rotundi-

3. Pyrola flexuosa Raf. 1816. folia Raf. 1816. Two opposite Stemless, radical leaves on long pe- leaves orbicular emarginate multitiolea, elliptical, both ends subacute, nerve, very smooth lucid, flowers remotely denticulate, scape flesuose racemose lax, bracts oblong lanceoraceme oblong dense.... Is it a variety late longer than peduncles, germ of $\boldsymbol{P}$.dentata? angular clavate curved reflexed,

4. Bigillaria ciliola Raf. 1816. spur filiform longer than germ peStem terete flexuose leaves clasping tals broad ovate, labellum filiform smooth ovate oblong acuminate, mar- obtuse.... Fine sp. stem 18 inches, gin ciliate glaucous beneath pedun-flowers white. It appears different cles uniflore, berries red....Very dif. both from O. macrophylla and Orbiferent from the Convallaria ciliata culata (nearer the last) by the raceof athors which is not a Sigillaria mose flowers, \&c. Leaves in all or Axillaria, but a Mayanthus or large nearly radical. Racemaria.

11. Caprifolum dentatum Raf.

5. Jathyrus incururs Raf. Foli-Leaves connate oblong acute remoteoles 8 ovate or obovate acute smooth Iy toothed, glaucous beneatl, last veins longitudinal, racemes axillary pair united in a campanulatc biacute multiflore incurved, peduncles cur- form, flowers sessile ternate, berries ved....On Lakes Erie and Ontario, reel.....Near C. flavum.

flowers blue amall. 


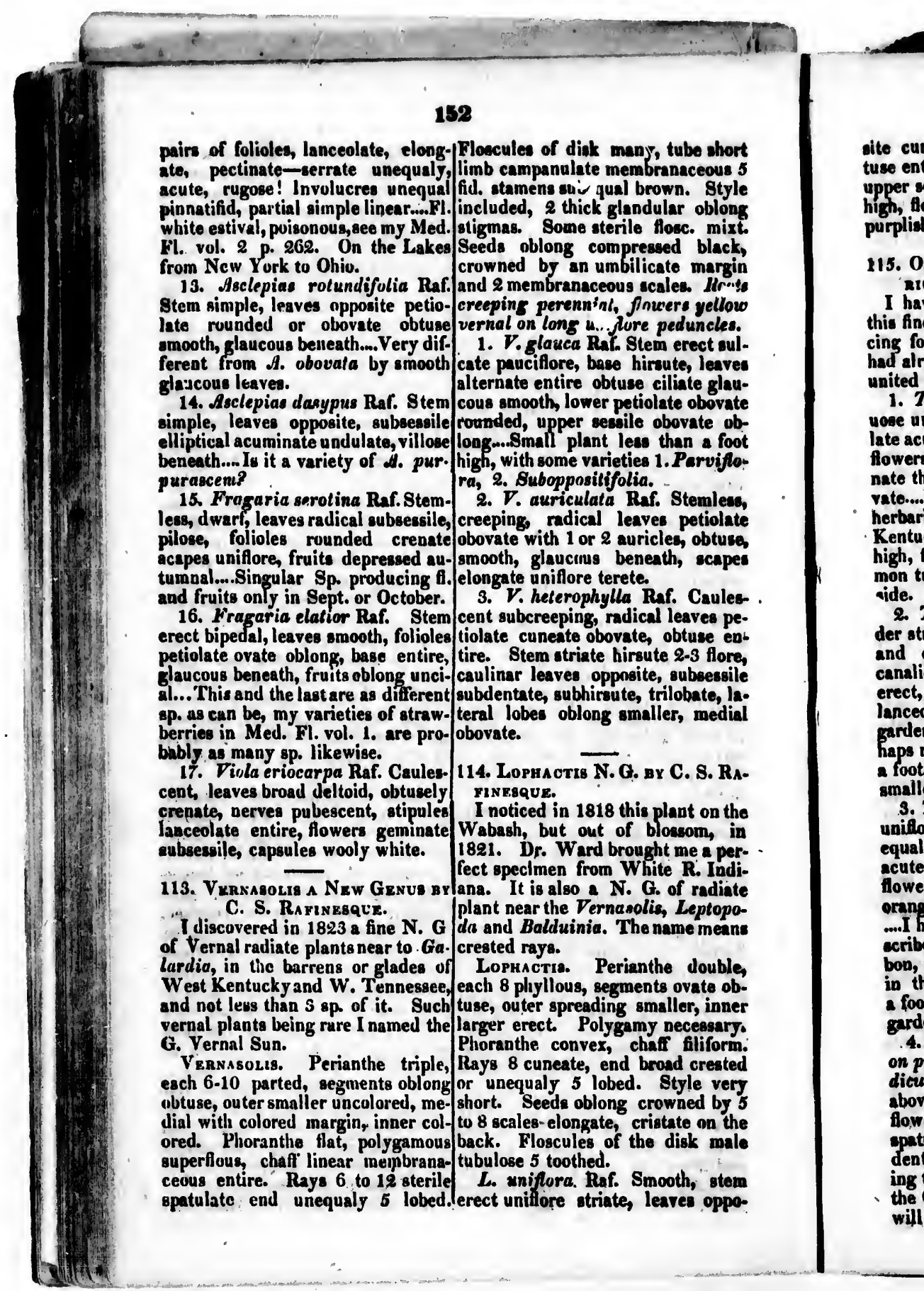


site cuncate lanceolate remoto ob-leuliar G. between Twlipa and Frl. tuse entire rugose, lower petiolate, tillaria. From the Oregun country. upper sesvile.....Stem 12 or 15 inches

high, tower estival, rays yellow, disk 116. Naw Plants or tha AlLy. purplish black.

ohant Mts. Br C. S. Rayizmsqur.

115. Ox 4 N. Sp. or Nontr AME. Among 30 rare planta collected atons Tulum ar C. S. R. this year in the Alleglanies of Ma-

I have the pleasure to introduce ryland and Pennsylvania one apthis fine G. into our Flora, by noti-pears to me a $\mathbf{N}$. G. and half a docing four N. Sp. of it; but Pursh zen are N. Sp. which I shall conhad already one, which he wrongly cisely designate.

united to Lilium or Lily. Perianthe

1. Tulipa bicolor Raf. Stem flex- polyphyllous in a double series. Phouose uniflore leaves that oval lanceo. ranthe flat. Chaff membranaceous late acuininate subundulate glaucous subtridentate, lateral teeth 1 or 2 onflowers erect, petals shortly acumi- equal. Kays 12 tot 5 narrow entire. nate the outer ovate, the inner obo-seeds compressed bidentate, teeth unvate....Native of Arkanzas, in 'my qual membranaceous. 'This $G$. has the herbariums seen alive in a garden of perianthe of lludbeckia, and the reKentucky in 1821. Stem one fout mainder as some sp. of Heliant/iun, high, flowers half the size of com-fout the rays as in Jianisteris ( $H$. mon tulips, white but lilac color out-pristatus) which has phoranthe hemiide.

2. Tulipa aurea Raf. Stem alen- Sun.

der streight uniflore, leaves radical 1 1. O. sulfurea Raf. Stem erect and caulinar slender graminiform, smooth atriated, leaves opposite or canaliculate, end falcates liower terriate, upper alternate, all sessile erect, petals yellow acuminate outer lanceolate rough, bsse acute, end lanceolate, inner ovate....Seen in acuminate, margin subserrates fowgardens, native place unknown, per- ers terminal, periantlie segments lihaps not American. Stem lesa than near lanceolute ciliate.... In meadowe a foot, flowern of a golden yellow, of mts. Stem 3 to 6 feet high, flowsmaller than the lant.

3. Tulipa montana Raf. Stem 1. Uniflora. 2. Paueiflora. 3. Muluniflore one leaved, radical leaves tiflora. 4. Ternifolia, \&ce. Probaequal to atem, elongate narrow flat bly a Helianthus of authors, which? acute, stem leaf ghort vaginate, 2. Sanouisorba palustris Raf. flower erect, petals lanceolate acute Stem virgate, folioles petiolate uneorange color, stamens equal in length qual elliptic, pectinate serrate, base .... I have not seen this sp. but I de. cordate, very smooth, lower leaves ecribe it from a drawing of Audu- on long petioles, upper leaves subbon, who discovered it in May 1809, sessile, spikes on long peduncles, in the Alleghany mountains. Over cylinilrical, bracts subulute, stamens a foot high, flower as large as the filiform clavate exserted....In a single garden tulip.

4. Tulipa pudica Raf. (Ambliri-feet high, entirely amooth, flowers on pudicum Raf. 1816.) Lilium pu. (white in a spike 3 to 5 inches long. dicum Pursh. Stem uniflore curved 3. Impatiens montana Raf. Stem above, leares lanceolate linear acute, flexuose very branched, leaves small flower pendulous petals obovate ovate oblong, acute at both ends, spatulate very obtuse, yellow....Evi- mucrouate, remotely mncronately dently a tulip by the habit and lack- serrate, peduncles so'itary 2-4 flore, ing the groove on the petals forming galea longer than the petals, spur the G. Lilium....If it has a style it resupinate short....In rocky streams will form a 8. G. Amblirion or pe- of the mts. stem 2 or 3 feet high, 


\section{4}

leaves and flowers sinall, t1. safiron|117. Coxchosoor. 'Two Nkw $B_{1}$ color with fow red upots: distinct from $I$. fulva.

4. Eryalmum angustifolium Raf.

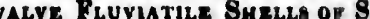
Amenion, Br C. S. Rafingiqu. These two fine shells are froin the leaves lincar oblong, base attenuate, end acute, very entire, racemes na-

permitted Peribo last March. They are style persistent....Probably the $E$. Ayres.

cheiranthoides of Pursh, Nuttal \&c. quite different from the European ditto which has large lanceolate den- hind and slanting, very smooth and tate leaves. Found in Marylund, dark brown outside, quite gaping annual, stem 3 to 6 inches, Howers belutv, iridescent white inside. Length mall yellow.

and diameter $\frac{1}{4}$ of breadth, axis at $\frac{1}{4}$.

5. Gerardin rupestris Raf. Very...Fine large sp. 6 inches broad, shell smooth, stem purplish fistuluse, /rather thick, beaks proeminent, not leaves sessile bipinnatifid, seginents gaping at the ends but below; hinge deep remote acute, sinusses rounded streight slanting ending in 2 sinall upper leaves oblong pectinate, bracts angles, no wrinkles on it, but slightlanceolate entirc, racemes often $\mathrm{rn}$ - ly Hexuulate beneath.

mose, secundiflore, peduncles short

2. Unio paphos Kaf. Oval, flexucalix 5 fid.... Fine Sp. siear $G$. glatc- use and subtruncate behind, with au ca, probably the real Khinantinus obliqual ridge from the beak, brown $V$ irginicus of $\mathbf{L}$. Stem 2 or 3 feet uutside with many minute concentric high, flowers yellow rather small. strias, inside purplish white. Length On the rock of the Alleghanies and $-3-3$, diameter $7 \cdot 18$, axis at $1 \cdot 3$ of Tuscarora mts.

the breadth....Pretty Sp. 2 inches

6. Verbena incarnata Raf. Stem brond, sliell rather thin for Unios, branched, leaves ovate lanceolate lanellar tooth slightly curved, carcerrate rough, flowers in simple slen- dinal tooth sub-bilobe crenate. Beaks der short spikes.... On the Juniata R. not prominent. one fuot high, llowers llesh colored,

difiers from V. urticifolia by narrow 118. ODATELIA N. G. of N. American Jeaves, spikes nut paniculute, nor Bivalve fuviatile shell. by C.S.Rqfinesgue. lowers white.

One of our Ohio abella, which has been

7. Arenaria sperguloides Raf. put with the writern it was unknown to me till I Stem procumbent diffuse very ramose otserved it in Prof. Green's cabinet, and leaves filiform setaceous in opposite I immedialely ascertained that it must fascicles smoith, flowers. in naked form a N. G. or group betwreen Anodonta panicles, calix acute....Akin to $A$. and Sulcularia.

glabra and st icta, but not erect and imperfect teeth. Cardinal tooth imper-

lesves like those of asparagus. On fect like a calloaity, with a large desinense a single rock in Pennsylvania.

us in Alawodon, becoming an imperfect

8. Glycine montana Raf. Stem lamellar tooth angular as in Lasmigona.... suberect flexuose angular pilose This G. must belong to the seriea of Anoback wards, leaves ternate, folioles Honta, but forms the passage with Alasmaoval acute, lateral ones oblique or subcordate at the base, stipulcs subuate, flowers solitary subsessile, pods/ed elongate, broader behind with sub. oblung Hat pendulous 2-3 seeded, truncate end, outside olivaceous brown, seeds lenticular.... On the top of the Alleghanies, annual, habit of $A m p h i$. carpa, but calix acute at basc, por sessile although attenuated at base, as in Glycine. wength 1.3 , diameter 2.9 , axis at 2.9 of the length.

Unio Oriens, Les.

Unio dehiacens. Say,

Anodontd prelonga. Green.

Breadil over 2 inches, shell rather thin

both cends rounded and brown.

trave

rica \&

Amer

norar

cient 
$\mathrm{Jew} \mathrm{B}_{1-}$

1.8 of $\mathrm{S}$.

NEPQUk.

irosn the

n, who

and de-

ire both

Buenos

- Oval

ader be-

soth and

gapings

. Lengtl

xis at $\frac{1}{3}$

ad, shell

ient, not

v hinge

$\mathcal{Q}$ sinal

t slight-

I, flexu-

with au

¿ brown

ncentric

Length

at 1.3 of

2 inches

$r$ Unios,

red, car-

to. Bealss

American

eqfinesque.

I has been

by diffe.

o me till I

binet, and

$t$ it must

Anodonta

a meaning

th imper

desinense

imperfect

migona....

es of Ano-

th Alasma-

ut it with

al flatten-

with sub.

us brown,

ridescent.

at 290 of

rather thin

\section{5}

FIFTI NUMBER FOR THE SPRING OF 1833.

Price 50 cents each number, or ONE Dollar per annum.

ALYANTHC JOTIRIAT

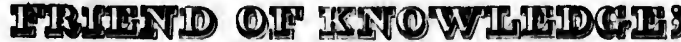

A QUARTERLY JOUIVAL OF

HISTORICAL AND A RUARAL SCIENCES, USBFUL KNOWLEDGE,\&O. WITII FiGullFs.

IjY C. S. RAIINESQUE

Professor of Historical and Nalural Sciences, Member of many learned Societies in America and Europe, Autlior of many Works, \&c. \&c.

Knowledge is the mental frod of man.

Vol. I. Philadelphia, Spkixg of $1833 . \quad$ No. 5

119. Ambrican Travelceis. Daiby, 1820. From New-

Who have written their tra- York to Detivit.

vels? The Americans are great Dunn, 1826. Guatimala.

travellers at home and abioad Dwight, 1828. Northern

for pleasure, licalth, or busi- States and $C$ - rada.

ness, as settlors, traders, sur- Flint, 1826. Western States. veyors, agents, missionaries, Hall, 1828. Ditto.

navigators, adventurers, \&c.; Hunter, 1823. Among Westbut few are qualified to write ern Indiaus.

their observations, fower still James \& Long, 1823. Miswrite them.

$I$ have sen to the society of Keating, 1824. To N.West. Geography of Paris, a long Mackenny, 1827. Lake Sucritical account of all these last perior.

from 1820 to 1832, dividing Morse, 1822, Among Indian them into 6 series. In general tribes.

travels at home or in N. Ame- Nuttall, 1821. Arkansas.

rica are the best, abroad the Poinsett, 1822. Mexico.

Americans are supercicial, ig- Rafinesque, 1818 to 1830.

norant of languages, and defi- Fragments of his travels in 18

cient in high acquirements. I States-1831. The Mexicans give here an abridgement of it. in 1830 .

First Series. Travellers in Schoolcraft, 1821. MisgisNorth America.

Astley, 1824. Opper Missou- Silliman, 1820. Canada,-

ri and New Mexico. Many excursions in his Jour-

Atwater, 1831. To N.West. nal.

Audubon, 1831. Florida, \&c. Smitl, (Jed) 1827. New

Catlin, 1832, On Missouri Mexico.

to Mandans.

Stanbury, 1822. Gr. Lakes. 


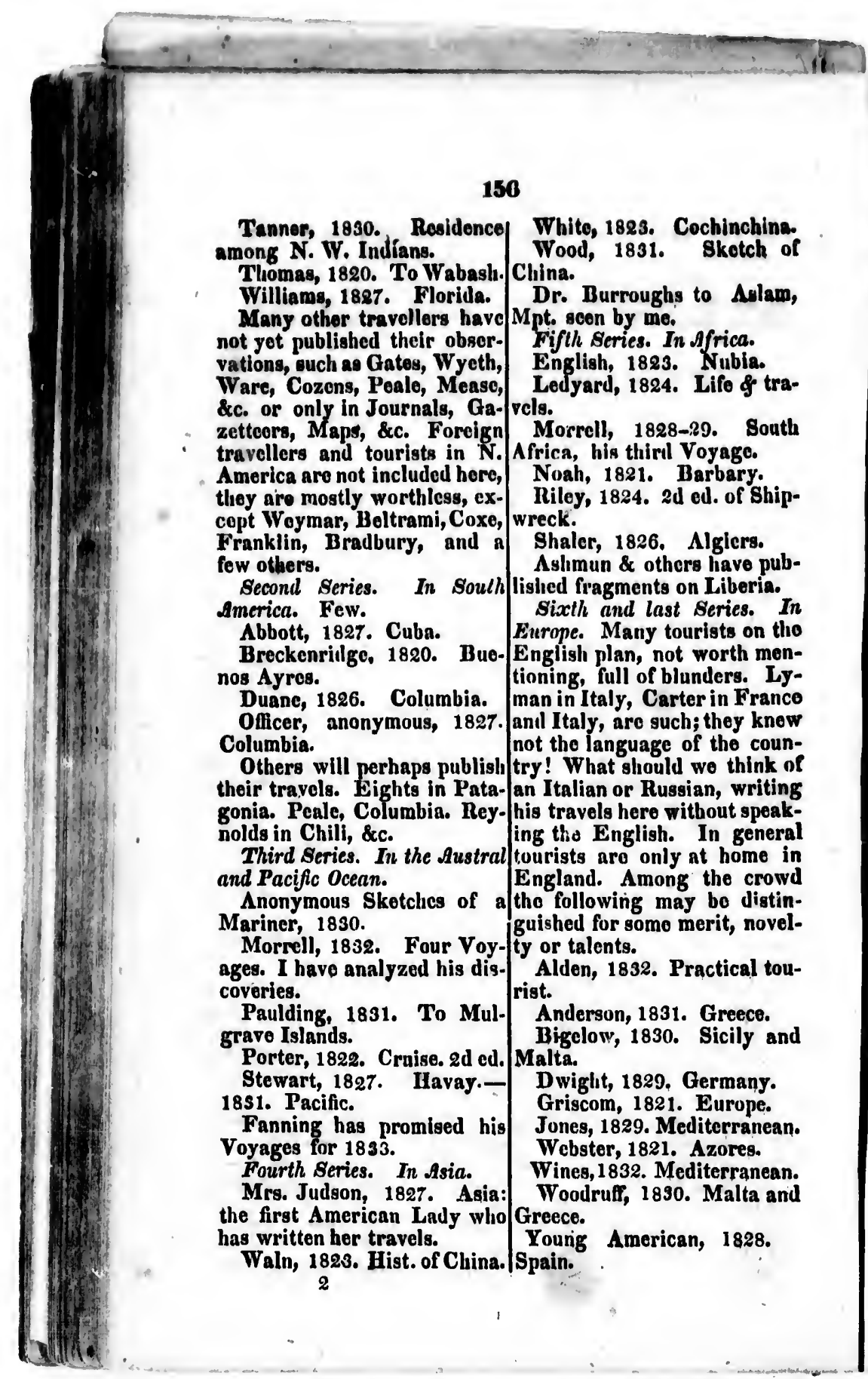



achins.
tch of Aulam, ca. ca. bia. \& traSouth ge. of Ship-

ers. tve pubberia.

ies. In $s$ on tho th menrs. LyFranco

ey knew

10 counthink of writing it speakgeneral home in - crowd - distin. $t$, novel-

ical toureece. cily and

many. urope. srranean. ores.

rranean. Ialta and

1828.
Willis is now writing vapid/somo periodicals havo refused Letters from Europe.

Dekay jromises a Voyage fact!

to T'urkey, but he spoke ucither Greek nor 'Turkish, ns 121. Aldeaninieg Modrusunl.

The dates aro tliose of publication. C. S. R. neglected in thic U. States; lakes and streams must be sur.

120. Rervarl of Merit. laped nud laid out in maps, The beautiful gold Medal harded to Prof. lRafinesque, hills are often nltogether omitby tho Geugraphical Society of tell or incorrectly delincated. Paris, has bcen received with Our fir'st Surveyors began their a Diploma of Merit. It bears surveys in tho level atlantic on one side the heal of Miner- region, when they camo to the va and on tho other a suitable hills and mountains they cominscription.

This Socicty is composed of ning lines near them, reducing tho most eminent and learned all elcvations to flat acres of men of Finnce. 'They have de- aerial surface instead of terrescided that tho question of the trial surface, thus three acres orlgin of inankind, and the in mountains aro often 4 or 5 in black nations is as yet insolin- reality. From these erroneble, owing to our imperfect ous survoys our maps are made. knowledgo of many languages; In some maps lofty mountains but they have appured and aro not even Inid out; thus the rowarled the memoirs and la- Catskill mountains 4000 feet bors of the writer, as one step high, are not'found in many towards such a solution, by inaps of $\mathbf{N}$. York. Tablelands connecting tho languages and and hills were altogether netraditions of all the nations of glected. Thus we bad no corthe world with the primitive rect delincation of our soil, cradle of mankind, Asia and slopes and elevations of land. the Imalay

It is believed that this is the trodnced in maps, they wero first instance of such an honor put down at random, at first being awardel to any Ameri- in heaps, laterly iu ridges. can citizen, by one of the most Thus was formed the opinion eminent learned Societies; for that all our mountains wero a labor at least of erudition in in parallel ridges. Yet notithe highest branches of histo- ing is more erroneous: rical knowleilge, philology and nearly all our mountains are ethnography.

But this kind of merit and Traux, rising by successive lofty knowledge is so littlc un-steps or in somo instances abderstood and valued hore, that ruptly, with some ridges and 
158

peaks in var:ous places, or in|tains, formerly called Talega. chains or groups.

wi, except in the S. \& $\mathbf{S}$. W. . I

Valleys are also neglected, was the first to trace their conand it is not sliewn whether tour or limits to the North, N. streams run in plains, basins, W. and West. Darby and ancient lakes, narrow valleys Thomas had long ago spoken or gullies. As early as 70 of the N. W. end of the Aleyears ago, Hntchins surveyed ghanies near lake Erie, 2000 the river Ohio and noticed feet high, but as late as 1832 some features of the valley they were not in our maps! where it flows; but later geo- yet they are there as in $\mathbf{N}$. E. graphers have not even attend- an abrupt rise of the Aleghany ed to his map, trusting to new tableland, 360 miles wide from flat surveys. In 1818 I sur-- lake Eric to the Catskill, and veyed again topographically quite connected in the North; that valley with all its hills, as the rise of the Delaware, gaps, bluffs, lakes, \&c. for Susquehanmah, Ohio and GeCramer and Spear of Pitts-Inessee streams ouglit to have burg, who paid me $\$ 100$ for indicated. Through N. Yor'k this labor; but have since re- this tableland sends many sold it to somebody else, and it hilly spur's between the minor has not yet appeared in our lakes, and has a broad apron general maps.

or tableland step forming the

Mr. Tanner, desirons to im- falls of Niagara and Genessee; prove his great map of the $U$. while at the falls of the MoStates, purchased from me last hawk a spur runs out to join year, my surveys of mountains, the Canadian and Primitive spurs, hills, knobs and table- mts of the North. At the N.E. lands, chicfly in the States of end they are called Kiskanon Kentucky, Indiana, Ohio, N. or Catskill mountains, and rise York and Pennsylvania. He abluptly 4000 feet.

has inserted them in his map of The Mattawan mountains 1832, which if compared with vulgarly called Highlands are the former map of 1830 , will primitive, and form a narrow evince a vast difference in phy- bioken tableland, cut up by sical geography. He has also the Hudson river, and tideinserted the tablelands and water, with peaks of 1500 feet; mountains of 'Tenuessec, from they run W. and $E$. and soon the late map of Rhea. And after become the Taconic mits. quite lately the Gold Mines running from S. to N. between Region has called forth a new the Hudson and Connecticut map of Peck, (in Silliman's basins, to become further off Journal) which delineates the the Green mts of Vermont South East slopes of our mts. and the White mts of New

We have then now something Hampshire and Maine, 7000 like a correct outline of the feet high, the highest of our contour of ourAlleghany moun- mountains, and the primitive 


\section{9}

Talega.

3. W.I

ir con-

rth, N.

by and

spoken

ic Ale-

e, 2000

is 1832

maps!

N. E.

leghany

de from

ill, and

North;

laware,

and Ge-

to have

N. York

many

o minor

d apron

ing the

enessee;

he Mo-

to join

rimitive

he N.E.

iskanon

and rise

ountains

ands are

narrow

$t$ up by

nd tide-

500 feet;

and soun

mic mits.

between

unecticut

rther off

Vermont

of New

ne, 7000

$t$ of our primitive nucleus of all the New England|Kitaniny mountain, which are mountaius anil hills. from 5 to 10 miles broad and

But leaving these Northern properly paralell spurs of the mountains to return to the Al- Alleghany separated by narleghanies proper, we find them row valleys while the 5 th or forming a broad tableland in most easterly is scparated by a North Pennsylvania, which broad valley, is of a different gradually becomes broken into and more primitive formation, ridges by the valleys and forming a tableland from ten streans. But the main or' to twenty miles wide; it is a middle branch dividing the long spur of the primitive Eastern and Western Waters, Mattawan mountains, called called the Backbonc mountain Sclooley mountains, in Newis yet a broad tableland in cen- Jersey, South mountains in ter county, and gradually, ta- Pennsylvania, Bluc ridge in pers to 20 and 10 miles breadth Maryland and Virginia; but at the Pittsburg and Cumber-- it is continuous only broken land roads; although our maps through by 5 River gaps, alrepresent it as a mere ridge, I though primitive it is much pointed out this error to MIr. Iowel than the second AlleghaTanner, but it could not be ny, averaging only 1000 feet conveniently corrected in his or one half of the average of the map, and thus is there yet! Alleghanies, yet it must be re-

The Delaware, Susquehan- collecterl that at the N. E. it nal, Juniata, and Potomac ri- rises to 7000 fect in the White vers rise in this tableland and mountains, and at the $\mathbf{S}$. E. to break through these ridges in 4500 feet in the Apalachian many places, forming many momntains, uniting these two successive watergaps, which distant groupe by a long narwere ancient outlets of moun- row band or chain.

tain lakes according to Vol- Beyond it easterly are two ney's theory, but as no fossil or thice smaller ranges of hills remains of fresh water animals forming as many steps and are found therein, it is very chiefly primitive; they bear probable that they were inland many different names from $\mathrm{New}$ seas and gulfs of salt water Jersey to Georgia, Pigeon hills when the Atlantic States were West of Susquehannah, Monunder water. The hudson ba- ocacy in Maryland, Bull hills sin above Newburg was also in Virginia, Yeona and Hope such an inland sea. All the fos- hills i:I Carolina and Georgia, sils of these inland seas are ma- yet they are consimilar forming rine exuvia of very ancient date chains broken by the streams, with a few diluvial remains. and average 500 fect in leigbt,

The principal ridges skirting but more to the $N$. anil $S_{\text {. at }}$ this Aleghany tableland are to the ends.

the east, 1 Turtle $m t$, 2 Side- In a $\mathbf{N}$. W. direction from ling $\mathrm{mt}$, 3 Tuscarora $\mathrm{mt}$, 4 Philadelphia to Lake Erie, 


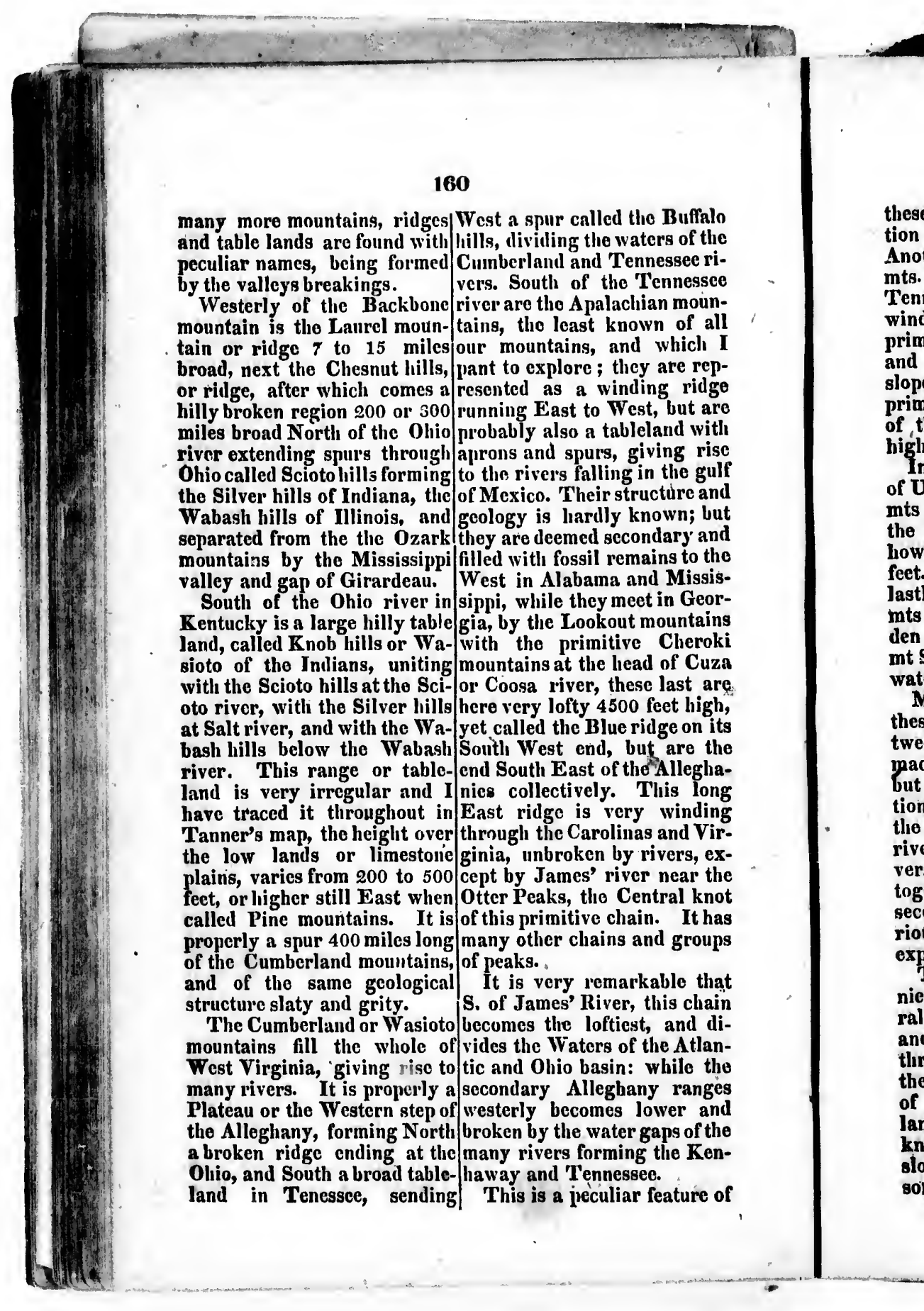


these $\mathrm{mts}$ in direct contradic- $1500 \mathrm{~m}: \mathrm{l}$ ? long from $\mathbf{N}$. E. to tion with the northern features. S. W. an! very unequally Another is found in the Unaka wide, with all the geological mts. (dividing $\mathbf{N}$.Carolina from formations among them.

Tennessec) forming a narrow There is nothing exactly winding ridge 4000 feet high, like elsewhere in the world: primitive on the eastern slope the Pyrenees, Apennines, Carand secondary on the western pathian, usually compared are slope. The Cowita mts also totally different in structure primitive are $\mathbf{E}$. of it and $\mathbf{W}$. and configuration. Therefore of the Blue Ridge, 3000 feet these interesting mts demand high. In east Tennessee or west geographer, geologist, minerof Unaka mts are 3 ranges of alogist, botanist, and philosomts between the branches of pher. I mean to explore them the Tennessee river. 1. Chil-levery year over again. Their howi 2500 feet. 2. Bay 2100 valuable mines of coal, iron, feet. 3. Clinch 2200 feet. and gold, \&c. begins to draw the atlastly comes the Cumberland tention of many; but I will seek mts 1800 feet, which by Wal- there the unexplored fossils, den $m$ t to the $N$. and Lisokout flowers, animals and precious mt S. form the great Tennessee stones which I know thcy conwater gap. tain: trking maps and surveys

Many names are given to of remote valleys and ranges these ranges in Virginia, be- to add to general knowiedge. tween the stream of the Poto- Is it not strange that while mac anil Kenhaway branches; our political geography (which but they are mere continua- is fluctuating every year) is so tions. 'Tlie Unaka mts become much attended to, altho' new the Iron ints, and S. of James maps are needed every ycar to river head, connecting trans- sliow new courties and towns: verse cliains, bind and blend physical geograplyy, which if together the primitive and once well drawn, would be secondary ranges in a very cu- forever "permanent, has been rious way not yet geologicaly so utterly neglected, or so long explained.

Thus far from the Alleghanies being a mere bundle of parallel ridges as geographers and geologists have supposed The nations dwelling in Authrough falso surveys, we find stral America were thus nickthem a vast and lofty mass named by Magellan, in 1520, of mingled mountains, table- from two Catalan words meanlands, peaks, hills, groups, ing hoof paw. For 312 years knobs, spurs, steps, aprons, past, they have been the subslopes, winding chains and ject of romances, fables and some parellel ridges: nearly systems. All the nations S. of 


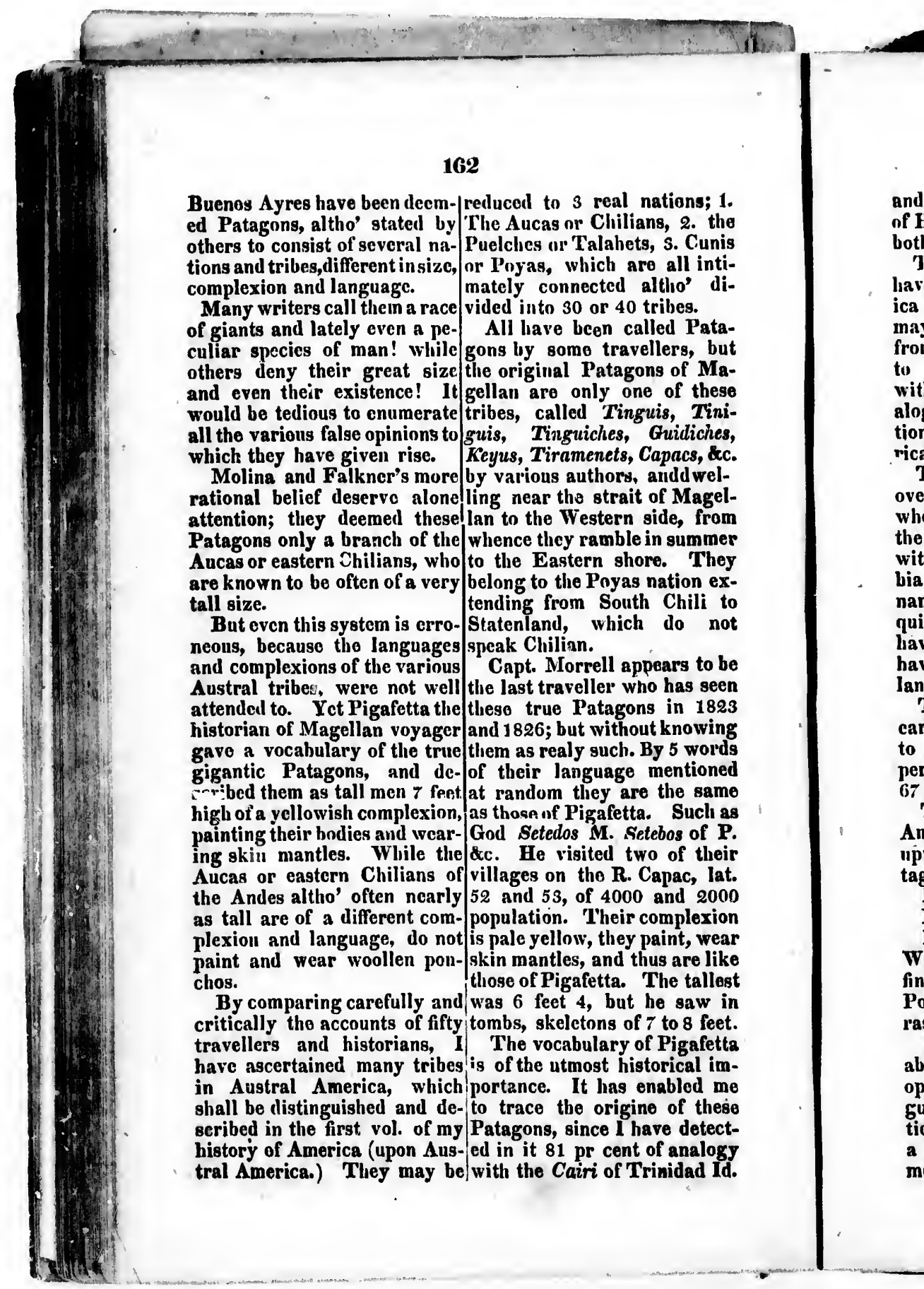


and 77 per cent with the Taino 123 . N. G. Catroma. Raf. of Hayti in the 16th centiry, This is a fine $\mathbf{N}$. G. of radiboth spoken by $\Lambda$ ruac nations. ate plants, discovered in 1818

This fine nation seems to in the barrens of West Kenliave overspread South Amer-- tucky, decmed then doubtful, ica to the very end, altho' it seen again in 1823 and ascermay be one of the last come tained to be a peculiar $G$. near from the East. since nearest to Rudbeckia and Sarcheta: the to the Atlantic shores, and/name means edged stem.

with striking philological an- Cauroma. Perianthe in doualogies with the ancient na-ble series 12 parted, Phorantions of Europe and North $\Lambda f$ - the convex, with biform chaffs, rica.

cxternal flat inembranaceous,

The Aruacs were spreal intcrnal linear carinate, amover all the West Indies, cxcept plectens, thick above. Rays 12 where driven off by their foes bidentate. Seeds oblong comthe Caribs, they were mingled pressed naked, no tectl.

with them in Guyana, Coluns- C. tomentosa Raf. Stem virbia and Brazil, under many gate simple, angular winged, names; even the Taos or Chi- wings tomentose; leaves sessile quitos of Claco appears to remote decurrent, lanceolate quitos of been a branch, since they rhomboidal, tomentose, end serhave 80 er cent analogy in rate acuminate: flowers termilanguages with the Taino. nal glomerate subsessile tomenThe famous Mulizcas so toes, perianthe lanceolate acute, carly civilized were also a kin rays yellow lanceolate.

to them, since they have 62 A singular plant 1 or 2 feet per cent analogy with the Tao, high, entirely wooly, blossom67 per cent with the Patagon. ing in June and July.

The other nations of South America with 50 per cent and 124. Principles of the Philosonpwards analogy with the $\mathrm{Pa}$ - phy of ucw Genera and new species of Plants and Ani-
tagons are,

Darien 68 per cent.

Mbaya 64 per cent.

Lule and Vilcla 50. mals.

Extract of a letter to $\mathrm{Dr}$. $J$. Torrey of New Fork dated 1 st While in North Amcrica we Dec. 1832.... I shall soon come find t' e Mayan, Cliontal and out with my avo wed principles Poyais each 60 per cent. 'Ta- about G. and Sp. partly anrasca 50 \&c.

Thus becomes evident how of Somiology, anil which $\mathrm{my}$ absurd and erroneous is the experience and researches ever opinion that American lan- since have coufirmed. The guages have no mutual affini- truth is that Species and pertics, and that the Patagons are haps Generu also, are forming a peculiar species of gigantic in organized beings by gradual men.

C. S. R. deviations of shapes, forms and 


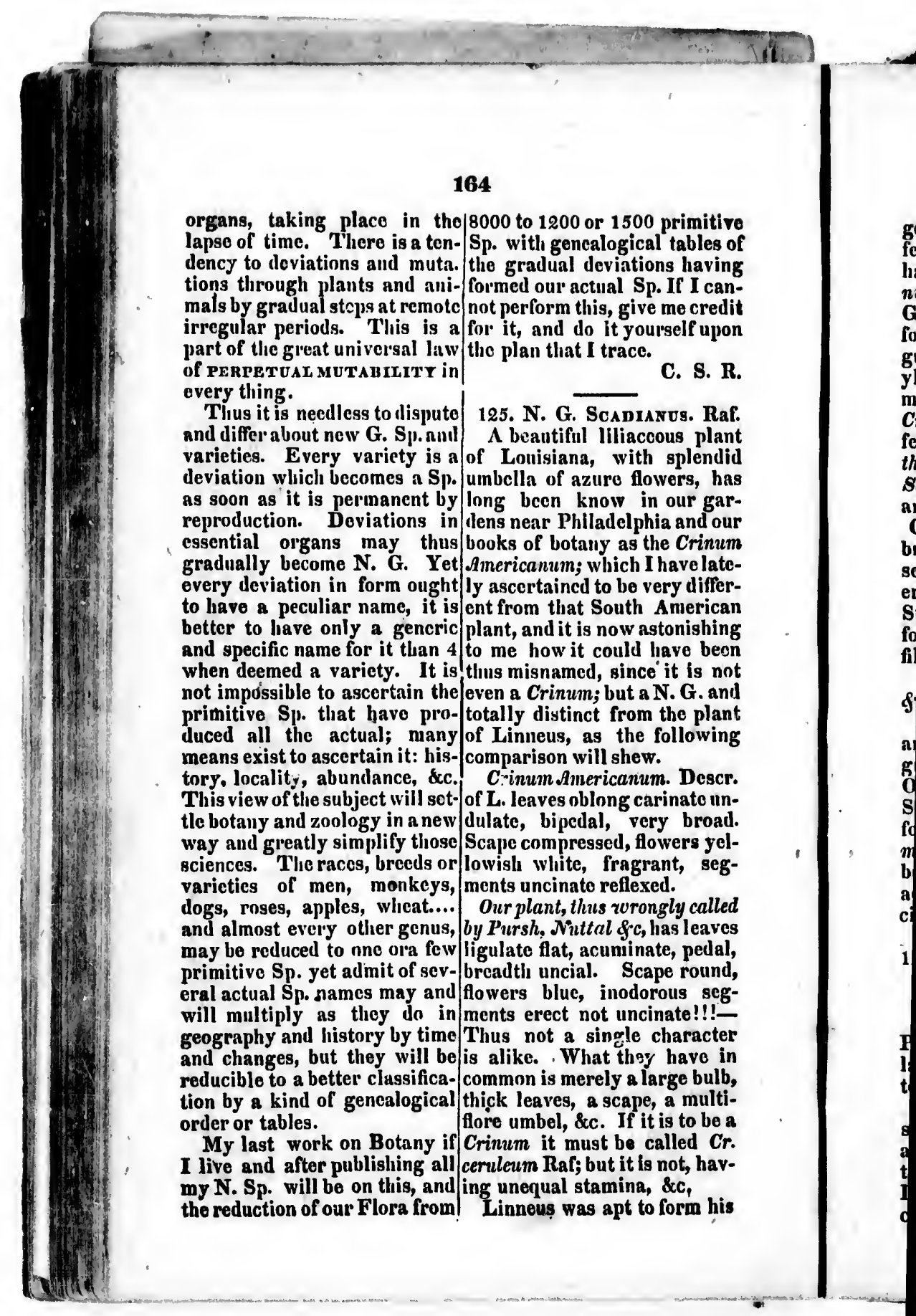




\section{5}

imitive

ables of

having

I I can-

e credit

If upon

S. R.

Is. Rat.

s plant

plendid

rs, has

ur gar-

and our

Crinum

ivolate-

y differ-

merican

nishing

ve been

$t$ is not

. G. and

e plant

llowing

Descr.

nate un-

broad.

ers yel-

it, seg-

ly called

is leaves

, pedal,

e round,

us seg-

ate!!!-

aracter

have in

ge bulb,

a multi-

$s$ to be a

lled $\mathrm{Cr}$.

10t, hav-

\&ic,

form his

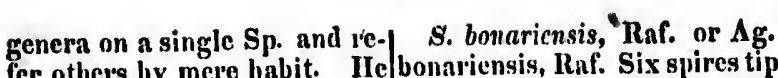
fer other's by mere habit. Ire tonerly obtuse, first spire with a has done so here. His G. Cri- transversal angle-shell about G. The $C$ nervosum must one inch long, whitish semiform the G. Stemonix by un- transparent, brittlc.

guiculate filaments and polypl/- 2. Stegomplix, Raf. N. G. yllous umbel. L'Heriticr has shell oval opening nearly round mado the G. Agapanthus with lips not quite joined, the inter-

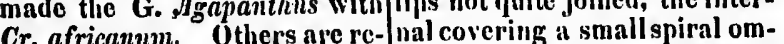
fered to Amarylis and IIcman-bilic.--'Therefore different thres. I propose to call this from Cyclostoma and Paluelina. Scadianns meaning bluc umbel, St. clegans, Raf. (or Cyclosand thus define it (toma) oval with 5 spires, white, Corolla with tube oblong, lim- enil nearly obtuse yellow,spires bus equal campanulate, six fid, witl many small prominent segments canaliculate, 3 broal- transversal strias.-One inch er obtuse, 3 narrower acute. long or less very pretty.

Stamens, 6 unequal curvel fili- 5. Diplicaria. Shell oval, form. Pistil oblong, frec. Style opening oval, columella broadfiliform streight,stigma simple. Iy plaited with 2 folds or thick

Compare this with Crinum oblique ribs.-Near Voluta 8. Amapanthus. and Torticella, but not marine.

This plant gave rise to D. bonaricnsis, Raf. Oval obanother singular blunder. It tuse sinooth olive color with 2 grows in the marshes of New spires only-small shell of half Orjeans, and is called Blue inch.

Squill, whence it was mistaken for the true Squill or Scilla 127. On 5 New Fresh Water maritima and collected as such! Shells, of Bengal and Assam but was found more suitable to in Asia.

adorn gardens than pharma- They have heen collected by cies.

Dr. Burrouglis and are in my cabinet.

126. On 3 N.G. of Land Shells 1. Planorbis albescens, Raf. from Buenos Ayres in 4 South ncarly smooth whitish flattened America. ByC.S. Rafinesque. on the riglit side with 3 raised

They are from the cabinet of spires, only 2 on the left in a Prof Green, where they are not hollow, opening hardly oblique. labelled, and who permitted me Size above half inch.

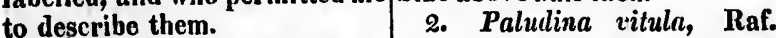

1. Siphalomphix, Raf. N. G. oval conical acute, 5 spires, shell conical, opening oval swelled before, olivaceous acute, end rounded, columella with narrow spiral brown twisted with a tubular ombilic. bands:-Size about one inch It differs from Agathina by the long. columella and ombilic. 


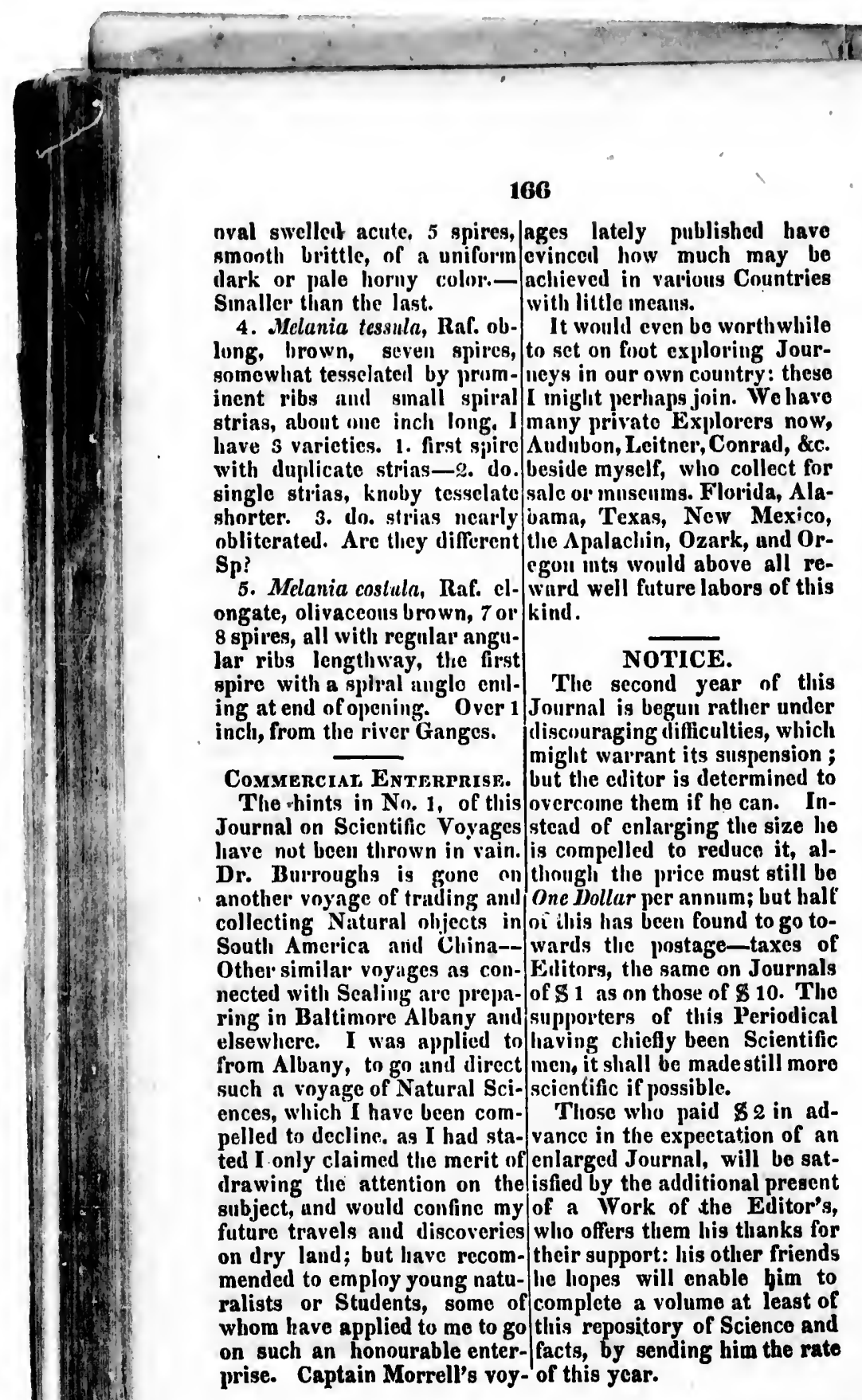




\section{7}

Account of the Botanical Collections of Professor C. S. Rafinesque.

$I$ began to herborize and collect plants in 1795, when a child. In 1815, 1 lost by my shipwreck all my early herbals of Europe and America, made during 20 years, among which a superb herbal of Sicily of 2000 species and 20,000 specimens. In 1816 I began over again in N. America, and have collected in 18 States and Canada during 16 years, have received besides, plants from all the States and Territories, from Missouri, Oregon and Texas, to Florida, explored our botanical gardens and public herbals, and exchanged with European botanists.

My own berbals contain now about 4200 N. American species, 5000 varieties, and 25,000 specimens, nine tenths of which have been collected by myself, and after exchanging or selling already 10,000 specimens. My foreign herbals contain about 3,000 species and 8000 specimens from Europe, Asia, Africa, Polynesia, South America aud Mexico. I have travelled for this nearly 15,000 miles, of which 5000 as a pedestrian botanist over N. America. My plants are chiefly plenogamous.

Those who have added to my N. Amer. herbals, are

1. Ladies: Miss Jane Šhort, Mrs. Mary Holley born Austin, Mrs. Wallace, Martin, Betton, \&c.

2. Professors and Doctors. Drs. Torrey, Short, Miller, Wal' " Crockatt, Hart, Macwilliams, Brereton, Mease; Brickell, Mitchell, Eddy, Crawford, Locké, \&c.

3. Botanical Authors. Bradbury, Lewis, Beck, Elliot, Conrad, Halsey, Eaton, Muhlenberg, \&c.

4. Gentlemen or Gardeners, \&c. Graissen, John C. Short, Ridgely, Hingston, Robert and John Carr, Steinhauer, Booth, Macarran, Knevels, Shultz, Waterhouse, Adlum, Forrest, .Iurand, Walton, Limner, \&c.

Those who have added to my exotic herbals, are

Decandolle, Moricand, Trattenick, Sieber, Bory, Hooker, Swainson, Sheperd, Romer, Shultze, Carr, Lesueur, Biyona, \&c.

Those who have bought or received some of my plants are, Decandolle, Moricaud, Torrey, Collins, Elliott, Maclure, Radi, Savi, Swainson, Bory, Vandermalen, Agardh, Schreber, Arnott, Hooker, Bastard, Lanthois, 


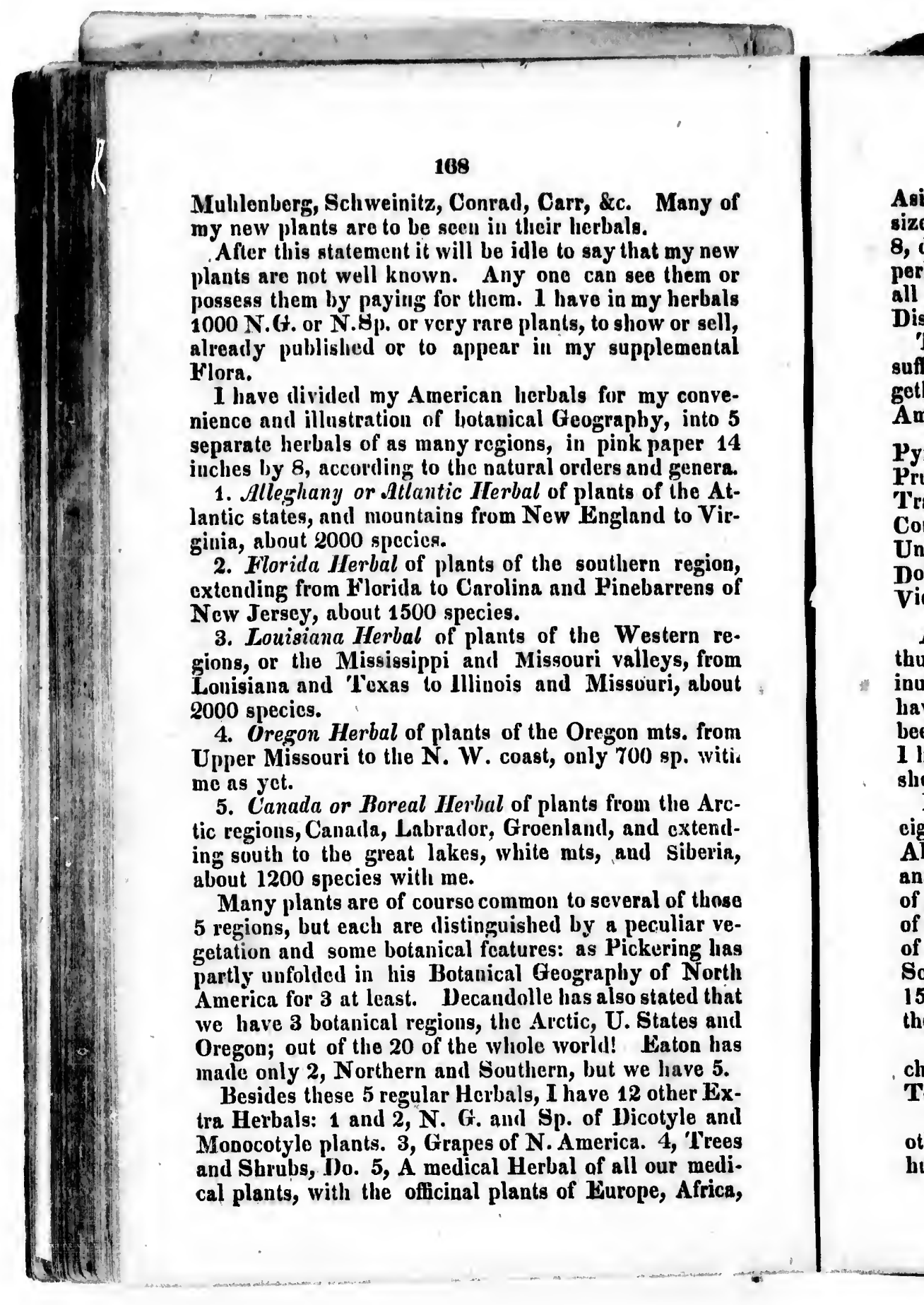




\section{8}

Asia, \&c. 1000 sp. 6, Extra herbals for sale, gigantic size to please those who like those. 7, ditto, good size. 8, ditto, Portable herbal of small plants. 9, ditto, Superb Herbal of beautiful showy flowers and plants, of all parts of the world, 800 sp. 10, Marine Herbal. 11, Diseased plants and monsters. 12, Agricultural lierbal.

'To show the rich contents of these herbals, it will be sufficient to state that of somo genera which 1 keep together for monograplis and peculiar stuily, 1 possess $\mathbf{N}$. American species of

Pyroln, 15 species. vitis, 36. Gentiana, 20.

Prunus, 32. Rosa, 24. Clintonia, 7.

Tradescantia, 15. Viburnum, 22. Pavia, 7 .

Conmelina, 10. Lobelia, 18. Anychia, 10.

Unisema, 9. Heuchera, 9. Onoclea, 5.

Dorlecatheon, 8. 'Trillium, 25. Iris, 12.

Viola, 40, \&c. Mesadenia, 10, Samolus, 5. \&c.

And in the same proportion with many other genera: thus have I increased 50 gencru of our Flora, like Fraxinus, Oarex, Quercus, Salix, $\Lambda$ ster, Kamunculus, \&c. have been by others. Whenever one of our plants has been deemed by any botanist similar to a Europeau one, 1 have tryed to put alongsido tho European plant, to show the difference or similitude.

Besides these $27 \mathrm{~N}$. American herbals $I$ have 15 forcign or Exotic herbals. 1, Of England anl France. 2, Alps. 3, Germany, Hungary, and Kussia. 4, Jtaly and Sicily. 5, Greece and Candia. 6, Asiatic herbal of Palestine, Syria, Persia, and Caucasus. 7, Plants of India and China. 8, Polynesian herbal. 9. Herbal of Egypt. 10, Crpe of Good Hope. 11, Africa. 12, South America. 13, West Indies. 14, Mexican States. 15, Mosses and confervas of all parts.--Of many of these I have but few species, altogether about 3000 .

As I travel every year I hope to add yet many sp. chiefly of the Southeru States. I shall perhaps visit Tennessee, Carolina and Alabama this year.

I offer to sell, buy or exchange such plants or any other. My price for my N. G. and N. Sp. is $\mathbf{\$ 1 0} 10$. per hundred, the same for gigantic plants. Other American 


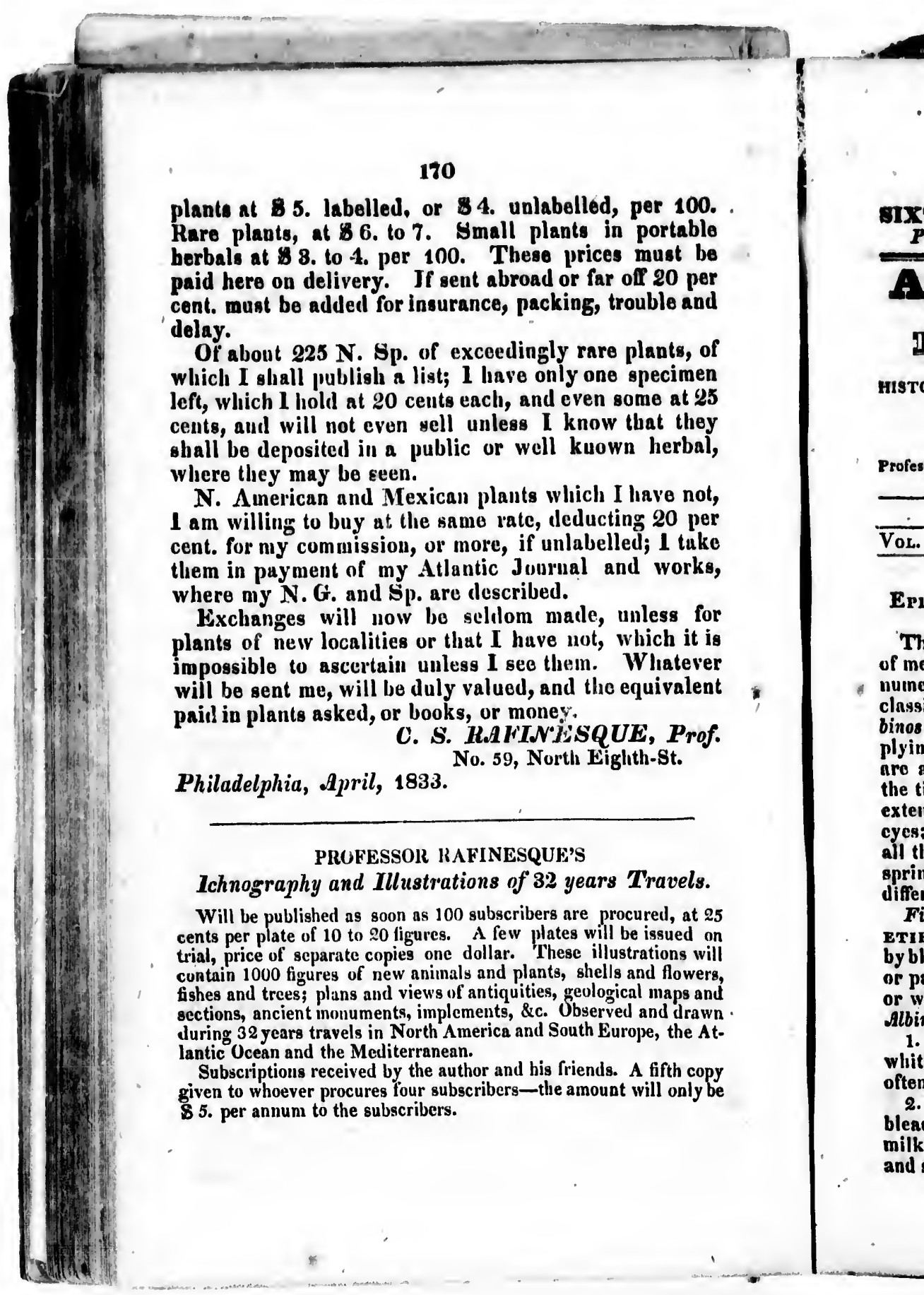




\section{Nr. 6.}

00. . blo

be

per

and

, of

nen

25
+25

hey

bal,

not,

per

ake

rks,

for

it is

it is
ever

lent

rof.

ls.

at 25

d on

s will

wers,

$s$ and

rawn

e At-

copy

ly be

DIXTH NUMBER FOR THE GUMMER OF 1889. Price 50 Cents each number, or ONE Dollar per annum.

ATHANTIC JOURINAT

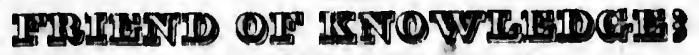

A QUARTERLY JOURNAJ, OF

HISTORICAL AND NATUKAL SCIBNCES, USIFUL KNOWLEDGE, WQ. WI'TH FIGURES.

BY C. S. RAFINESQUE

Professor of Hintorical and Natural Sciences, Member of many learned Bocie. ties in America and Burope, Author of many Worka, \&cc. \&e.

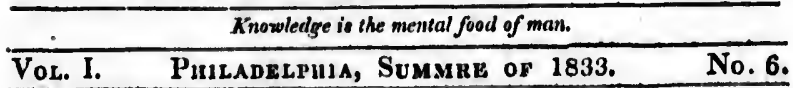

\begin{tabular}{l|l}
\hline Article 130. & 3. Var. Palins. Skin pale
\end{tabular}
\begin{tabular}{l|l} 
Article 130. & 3. Var. Palins. Skin pale \\
Epidermic Variestes of & or i,rownish (like cofiee and
\end{tabular} Mus misu.

Theso rarieties in the skin slaty or redish.

of mell are now known to be so 4. Var. Scalins. Skill white numerous, that they rerguire a scaly, cheeks torid, hair palo classification: the name of Al-silky, cyes blue and weak. In binos often givent them, not ap- Polynesia.

plying excent to a few. They 5. Var. Quimos. Skin pale are all Natural deviations in tawny, hair pale, short, wooly, the tissue und color of tho skin, eyes pale, dwarfish body, long extending also to the linir and arms, \&c. In Madagascar.

cyes; occasionally evolved in Second Series. Maradro all the parts of the world, and VARIETIEs, or Natural Devi. springing from parents of a ations by mixture of dark and different hise.

First Series. Ambinio vant- 6. Var. Meladins. Skin half ETies or Natural Deviations, white or pale, and half brown by bleacling the skin and hair, or black, hair and eyes variaor passage from dark to paler ble, little deviated.

or whiter complexions. True 7. Var. Pintados. Skin with Albinos. brown or black spots in the

1. Var. Lactins. Skin milk white race, pale or white in the white, hair white, silky, eyes black race, hair silky, and often red and weak. often small eyes.

2. Var. Albins. Skin white or 8. Var. Lividins. Skin with bleached, neither florid nqr irsegular spots of a Jivid red milky, hair bleached or grey color, called birth spots, or and silky, eyes blue or whitisl. bloody spots; not a disease, 


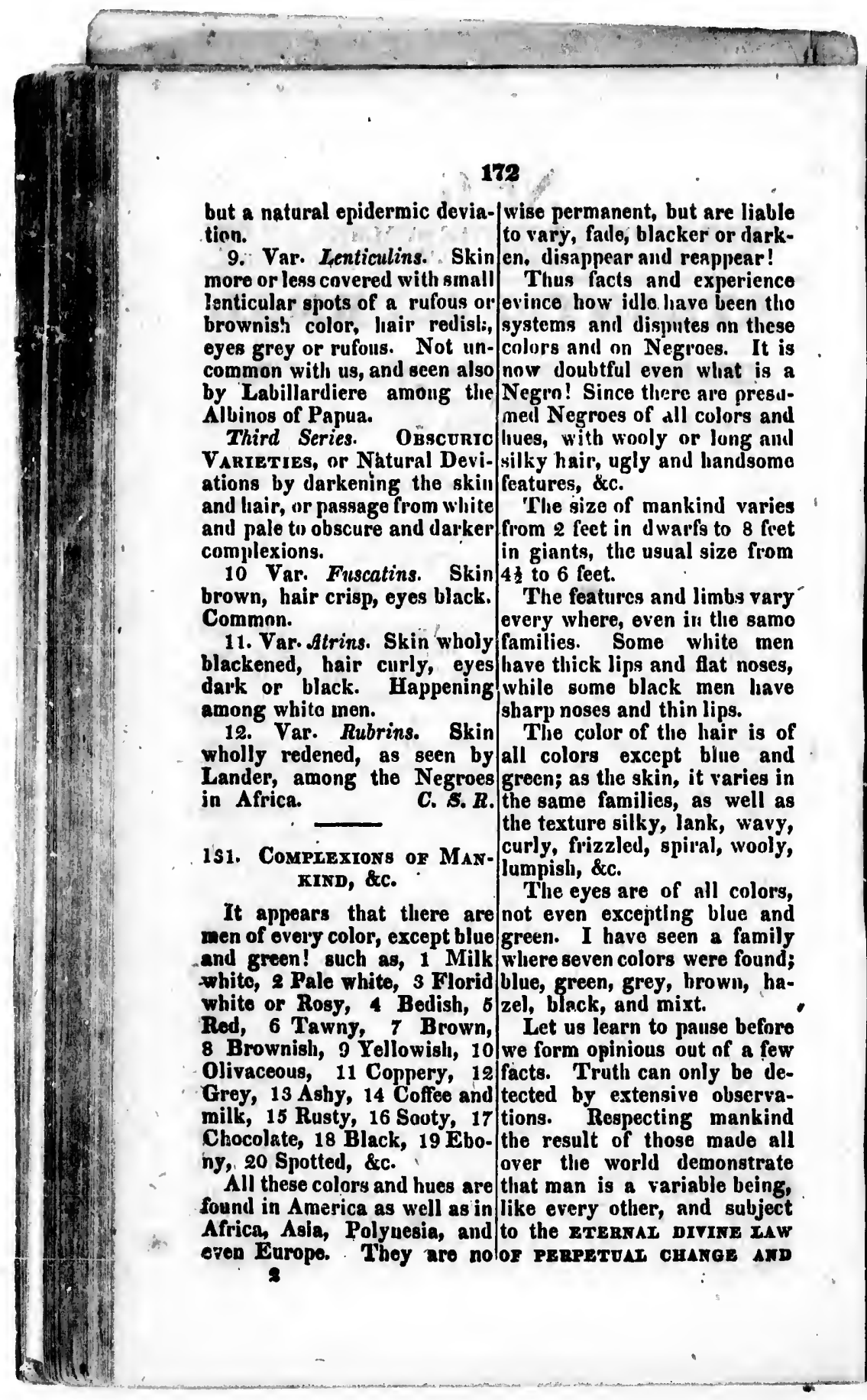

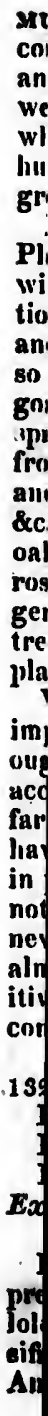




\section{8}

Muratror, in form size and know but few of the primitive complexlon as well as manners languages of that continent; and in provements. Whence but amnng the modern we find we ouglit to love each other dialects of several langiages whatever be our sliape, bulk anil willely spread across the whole hue, as brothers of a single of Africa, and each offering great family.- Atriking analogies with the

Each Genus of Animals and English, evon among the NePlants is also a similar family, gion nations.

with few or many old devia- I shall enumerate the Afritions which we call species, can languages under $s$ classes. and varie!ies, at random! It is 1 Ancient African languages. 80 with the dogs and cats, 2 Languages of the Brown goats and mice, hawks and mations. 3 Of the Black or iparrows, ducks and guills,- Negro nations.

frogs and turtles,-lierrings I. Ancient Languages of Afand carps,-flies und moths, rica.

\&c. among animals. - And Tliose of which I can ofier oaks, vines, apples, clierries, coinparative tables are merely roses, lilies, rice, barley, wheat, 1 Coptic. 2 Ammonian. 3 Lygentian, spunges, \&c. ainong bian, and 4 Guanche.

trees, slı'ubs, flowers, and 1 Lang. Egyptian or Coptic. plants. $\quad$ This was the language of

Whence genera are of more anclent Egypt, al reacly spoken importance than species, and 4500 ycars ago, and which beought to be closely studied or came extinct only towards uccurately fixed; but we are 1620 . But we have many books, far frum this as yet; species ioscriptions, and manuscripts have been too much attended in tliat langnage. It has conin preference. But genera are siderable analogies with the not few, inany thuusands of Pelagian, Scythian, Sauscrit, new ones exist as yet, since ancl primitive dialects of Asig almost every genuine or 1 rim- and Europe. It extended to itive species will be found to Nubia, Abyssinia, and part of constitute a peculiar genus. Lybia, in many dialects, 3 of which prevailed in Egypt. 1 132. Affinities of the English Tlio 'Theban, 2 the Memplitic

Language with the African or Northern. which changed P

Languages and Dialects of into $P H$ or $F$, and $K$ into $K h$

Egypt, \&c. Extract from my Philosophy of ing $\mathbf{R}$ into $\mathbf{L}$.

the English Language. The primitive Phonology of In Africa a great obscurity Coptic, was very simple. It prevails on the subject of Phi-had only 12 lettera, which Jological and ethnological clas- were often diphnnous or polysification, nearly equal to the plinnous -3 vowels, $\mathbf{A}, 0$ or $U$, American perplexity. Wo E or I, the simple consonants 


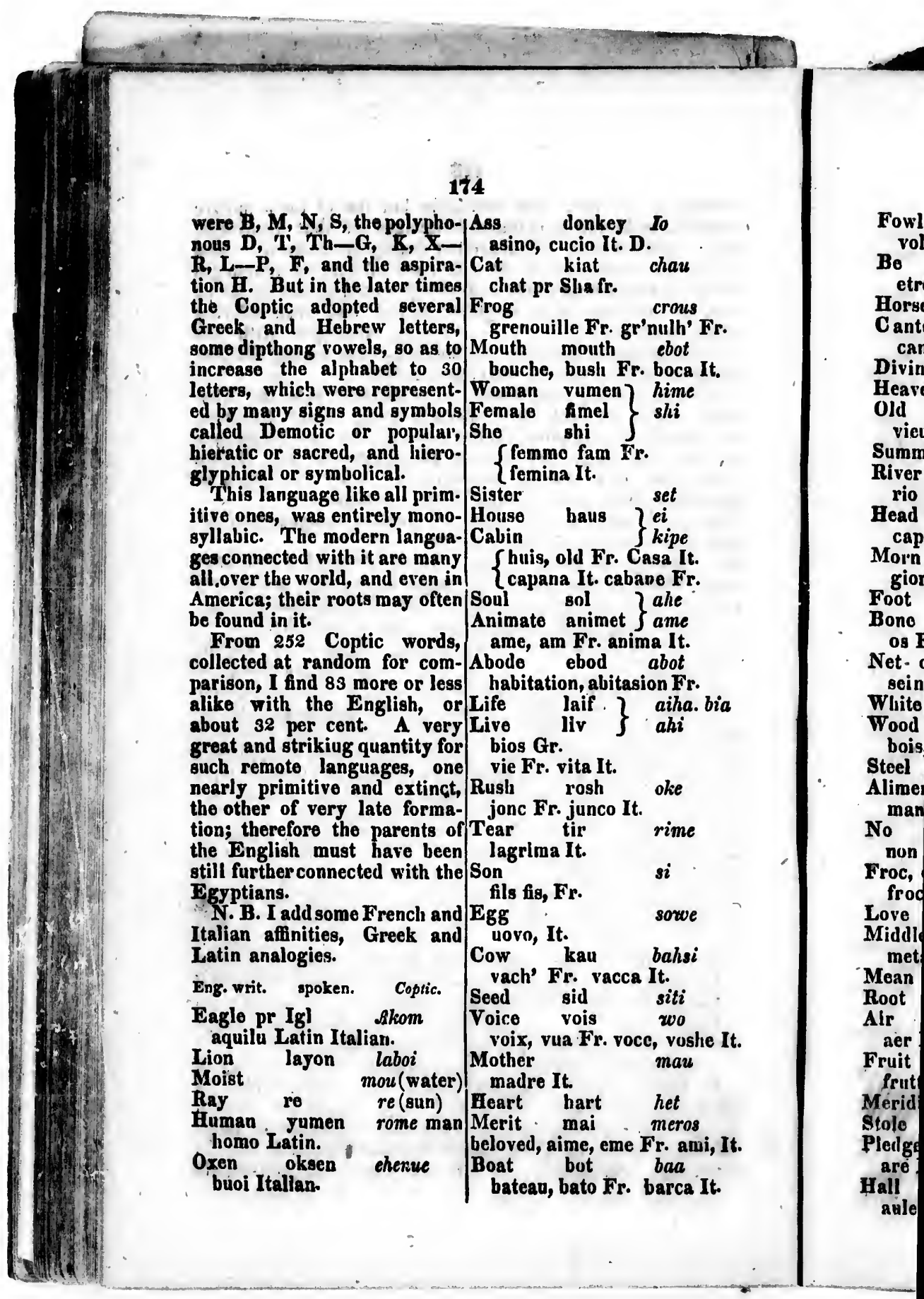


Fowl faul halet

volaille, volalb' Fr.

etre $\mathbf{F}$.

Horse hors

Canto, or song canto It.4

Divinity, deity

Heaven hevn

Old

neifui

hello

vicux, vielle, viœ', vielh' $F$

Summer, somer som

River

iaro

rio It. Sp

Head hed

capo It. Sp.

Morn

ape

giorno, djiorno It. day.

Foot fut

Bono kas

os Fr. costa It rib

Net- or seine, sen' chne

seine Fr. pr sen'

White vuait wouah
Wood vud woh

Wood vud

Steel stil

stil stali mange, mang' Fr.

No

nun Fr. an Gr.

Froc, dress

froc $\mathrm{Fr}$.

Middle midl

meta It.

Mean min mini

Root rut ruti

Air er aer

aer Lat. a ria It.

Fruit fruit utah

frutta It.

Meridional, south, meri

Stole hol kohl

Pleilge pledj dreb

are $\mathbf{F r}$. capara It.

Hall arle Gr.

Yet
eti Gr.
One

Sow

Swine

Tall

Dumb domb thom

muto It.

Cott, cottage kot

Lick legh

. . mim

mhav

Wish wesh
Free fri

eremos Gr.

Sapient (wise) sabe

Six siks sohu

sei It.

Save sev sot

sauve, sov Fr.

Frost (winter) fro

Shift, change shibte change, chanj $\mathbf{F r}$.

Four fuer Ftohu

Enough enof enouff

Job, work hob

opera It. obra Sp.

Calm kiam gham

Camel ghamul

Royal raoh

Cave (kev. tabernacle)-thebi caberna Sp.

133. Borex dichrurus. N. Sp. of Shirew.

I discovered this new small quadruped, in 1826, at the falls of Niagara; it had been caught even on Coat Island, in tho

middle of the falls, and preserved in the Museum of the Falls. It must dwell both in

Canada and New York, but

is rare, not having seen it else-

where. - The specific name,

means tali bicolored. 


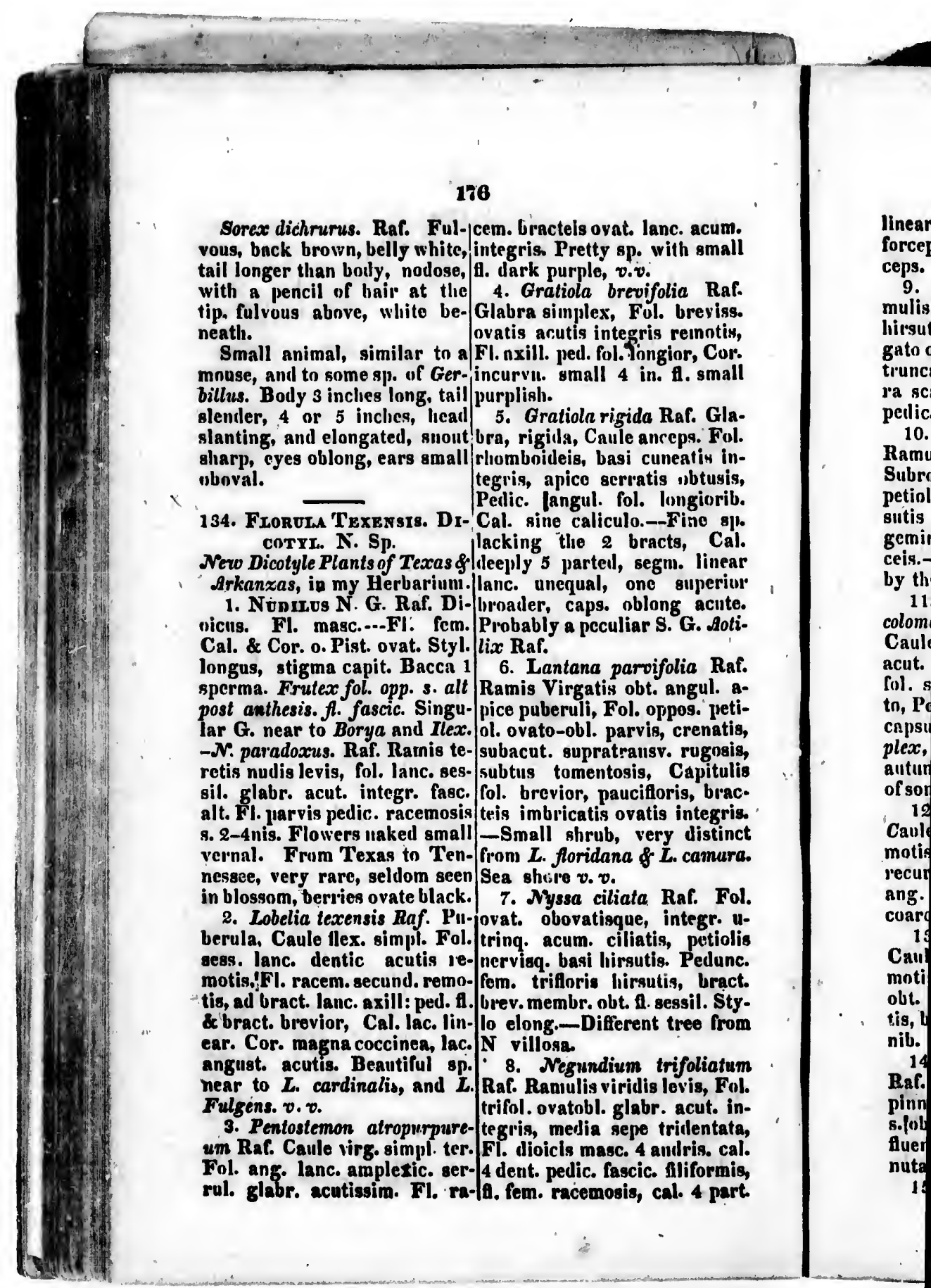


eviss.

notis,

Cor.

small

Gla-

Fol.

is in-

tusis,

giorib.

$108 \%$

Cal.

linear

iperion:

acute.

Aoti-

Raf.

cul. a-

g. peti-

enatis,

ugosis,

ipitulis

, birac.

itegris.

distinct

:amura.

f. Fol.

egr. U-

petiolis

edunc.

bract.

il. Sty-

ee from

oliatum

is, Fol.

cut. in-

lentata

ris. cal.

iformis,

4 part.

177

IInear. pist. bipart, incurvis|Raf. Repens, hirsuta, fol. Jonforceps emulans, stylis in fur- gepetiol. subrotundis ovatis, ceps. $v$. v.

repanto crenatis.

9. Celtis longifolia Raf. Ra- 16. Didiph1s N. G. Raf. Cal. mulis gracilis verrucosis, a pice camp. 4 fid. Cor. o. stam. 2. hirsutis. Fol. distichis, elou- stigm. 2. capa. biloc. polysp.gato oblongis acum. basi obliq. D. linearis Raf. Caule erecto, truncatis, eigual. serratis, sup- fol. oppos. lincar. elongatis inra scabris, subtus reticulatis, tegris, fl. axill sess. solit. - Pepedic. solit, 10. Fagus rolundifolia Rnf. Quite a distinct G. from Peplis Ramulis fuscatis levis. Fol. Gandr. G.

Subrotundis repandis acutis, 17. Eutmon N. G: Raf.Cal. petinlis nervis marginiq. hir- 5 phyl. eq. cor. 5 pet. stam. 5 sutis sericeis. Capitulis sepe alterna styl. 1, stigma 3 lob. geminatis, ped. bracteisq. seri-l caps. 1 loc. 3 valv. polysp. sem. ceis.-Differs from $\boldsymbol{F}$. sylvatica centralis. $\boldsymbol{E}$. napiforme Raf. by the round repand leavcs \&c.' Rad. tuberosa, fol. rad. teretib.

11. Euploorbia (Esula) len- carnosis, cyma corymb. dichocoloma Raf. 1820. Glabra, toma, Talinum s. PhemeranCaule crecto fol. sessil. obov. thus napiforme Dec. My speacut. integr. Unib. trifi:! bract. cimen from a garden Is imperful siunilis marg. albo colora- fect, but cridently sliows that to, Periantho apice albo 4 lobo, it is a N.S. $v$. $v$.

capsulis villosis.-Var 1 Sim- 18. Convolvulus g iseus Raf. plex, 2 Elatior, 3 Cuneifolia, Volubilis, fol. longepetiol. corautumnal plant. $\boldsymbol{E}$. marginata datis subtrilobis, 3 nervis, denof some Bot. not of Kunth. v. v. tieulatis, acutis, puberulis fur-

12. Achillea gracilis Raf. furaceis griseis. Pedic. bievis Caule gracile striato, Fol. re- unifl. Cal. griseus, bracteis bimotis angustis, infimis petiol. nis lanceol. caliculans. Near recurratis, pinnatis, foliol. S. G. Calistegia.

ang. pinnatif. corymbol parvo 19. Desmonema N. G. Raf. coarctato. Semipedal, fl. white. Perianth. ext. tubul. 5 dent. s.

13. Fedia brevifolia Raf. ó phyl. segm. connivens. PeriCaule gracile furcato, fol, re- antli-intern. petaloid. 5 segni. motis paucis brevia, spatul. obl. membr. ad ext. brevior, cuneat. obt. integr. FI. paucis gemina- emarg. Stam. plurima ad bas. tis, bracteis ovatis acutis, semi- gynophoro inserta, equalis, nib. 4 lentatis - semipedal. Piascicul. albis filif. vix articul. 14. Polemonium quadrifiorum persistens, simultaneis evolvRaf. Caule erecto ramoso, Fol. ens, interdum castratis, anth. pinnatis, foliolis 11-17 ovatis parvis deciluis. Gynophoro pilobl. acut. integr. ultimis con- centrale elongato trigono, stam. fluentibus, Fl. term. sub 4 nis. \& cal. longiur. Ovar. glabr. nutans pubescens blue." glob. apice trilobo; stylis 3

15. Glechoma rotundi folia simpl. brevi. Caps. levis 3

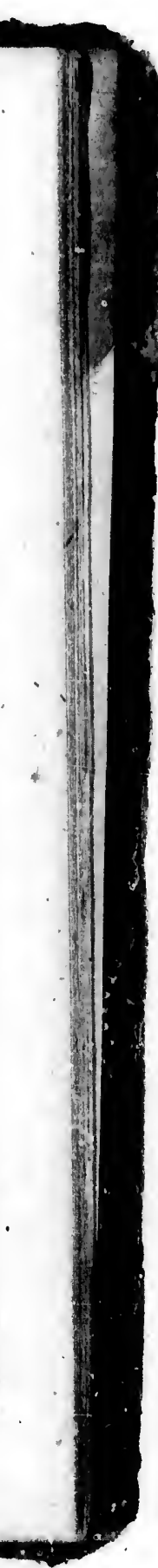




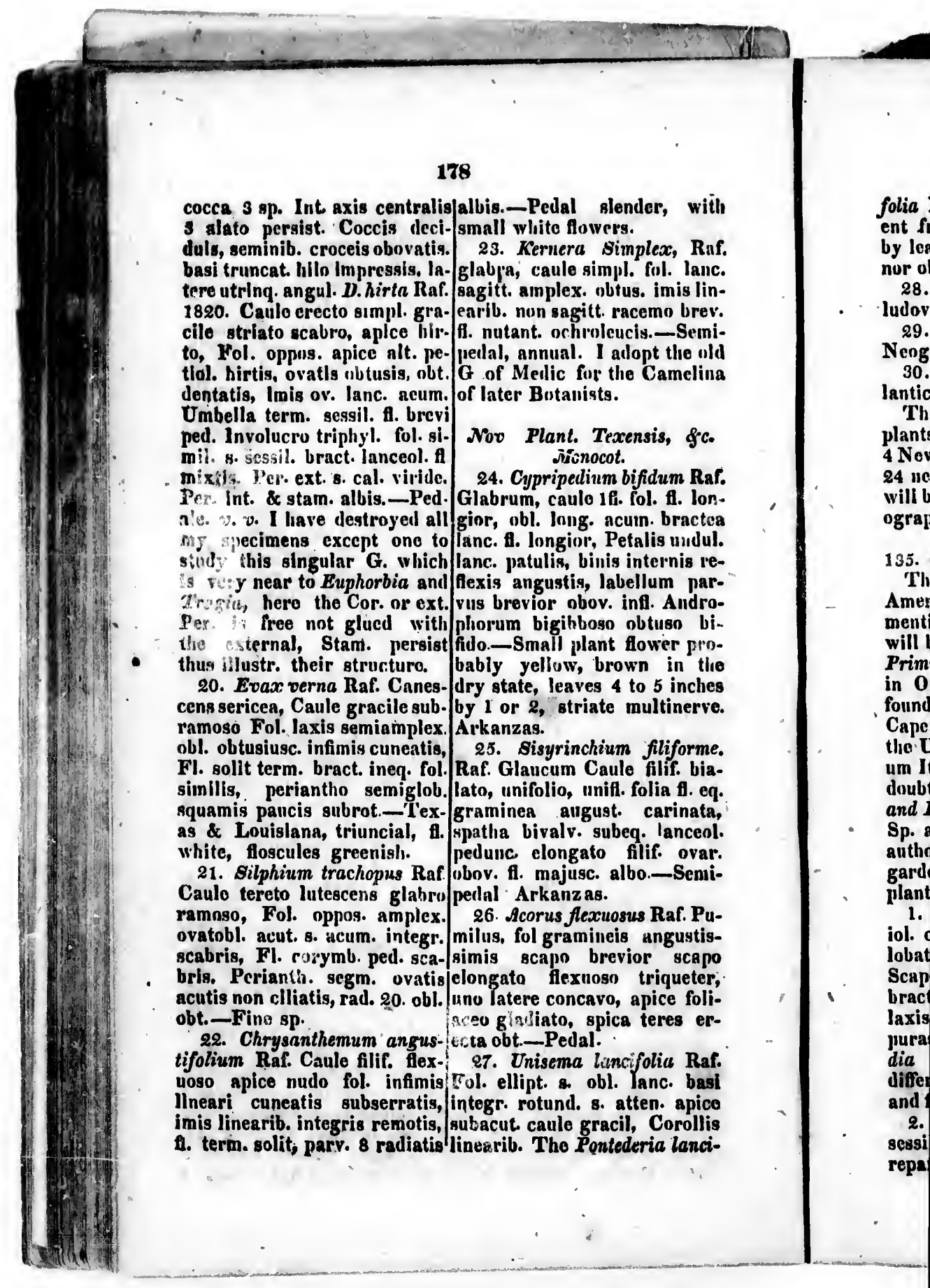


vith

Raf.

inc.

lin.

mi-

(1)

lina

ic.

Raf.

lon.

ctea

dul.

re-

lar-

bi-

rin-

the

hes

rve.

$m e$

ia.

(a)

ata

eol

var.

mi-

Pu-

itis.

ape

apc

oli-

er.

(1)

Raf

basi

ice

ilis

nci-

folia Mg. and Elliott. differ-lapice anceps, umbolla paucifi. ent from my U. Leterophylla $8 \mathrm{f}$. bract, lancenl pedic laxis by leaves never cordate at base curvis, cor. planis. obt. albis. nur obt. at end $v$. $v$.

28. Iris brevicaulis Raf. fl. $v$.

ludov. sp. 56.v.v.

3. D. ovatum Raf. sessil.

29. Etheosunthes ciliata Raf. ovitis obtus. basi attenuatis,

Neog. 1825. v. v.

30. Tulipa bicolor Raf. At- umbella inultifl. 20H. bracteis lantic Journal $\mathbf{N} 4, v \cdot v$. miniuis lanceol. pelic fastig,

This fascicle of rare S. W. rectis. Col. acutis undul. anplants contains 4 N. G. 1 S. G. gustis purpureis.-Mountains 4 Now trees, 2 ncw shrubs and Unakaand Apalachinn. $v$. $v$, in 24 new plants. Several otlieis garl. as $D$. meadia. vill be mentionel in the Mon- 4. J. obovatum Raf. Fol. ographs of revised Gencra.

petiol. obovatis obtusis vix repandis, scapo tereto apice 135. G. Dodecatheon or Meadia. compr. Umbella laxa multifl. r. This beautiful G. strictly N. 206. ped curvis. Cor unilul. Amer. although Langsdorf obtus. purpureis -Virgiuia. mentions one seen in Siberia, $v$. $v$.

will be found as numerous as 5. D. Serratum Raf. Fol Primula! there are many Sp. petiol. ubl. lanc. obtusis hasi in Oregon and one has been cuneatis subserratis, apice rein Oregon and one hear the Icy note denticul. Scapo tereto, Cape; the following $12 \mathrm{Sp}$. of unn latere sulcato, Umb. pauthe U. St. are in iny Herbari- cifl. 8fl. fastig. bract, ov. lanc. um It may now be a matter of Cor. undul. albis. Illinois. $v$. doubt which is the true Meadia $v$.

and Integrifolium, many of $\mathrm{my}$ 6. D. parvifolium Raf. Fol: and Integrifolium, many of my netiol. cuneatis obl. obt. intean. gardens; although different reto, Umb. paucifl 8f. bracplants! All rare vernal plants, teis oblongis obtus. ped. cur-

1. D. cordatum Raf. Fol pet- vis, Cor. planis obtus. albisiol. cord. ovat. obliq. sinuato mts. Cumuertand $v$. $v$.

lobatis, obt. lubis iner. dentat. T. D. unditum. Raf Fol. sub. Scapo angulato, unbella $20 \mathrm{f}$ petiol. cuneaiis obtusis undatis. bract. ovat. pedic. ineq. flex, scapo tereto umbella paucif. laxis, Cor. planis obtus. pur- bract. ovato lanc. Cor. unilatis purasc. Sent me as D. mea- purpureis.-Mts. Alleghany. dia frem a garden, totally 8. D. Cuneatum Raf. Fól different, beautiful, large leaves sessilib. cuneif. acutis vix reand flowers. pandis, scapu tereto, Umb. 2. D. ellipticum . Raf. Fol. fastig. paucifl. 5.7ff. bract. sessil. ellipt. obl. acutiusc. sub- obl. acut. Cor, undul. purp. repandis, scapo tereto striato -Allegh. mts. of Maryland,

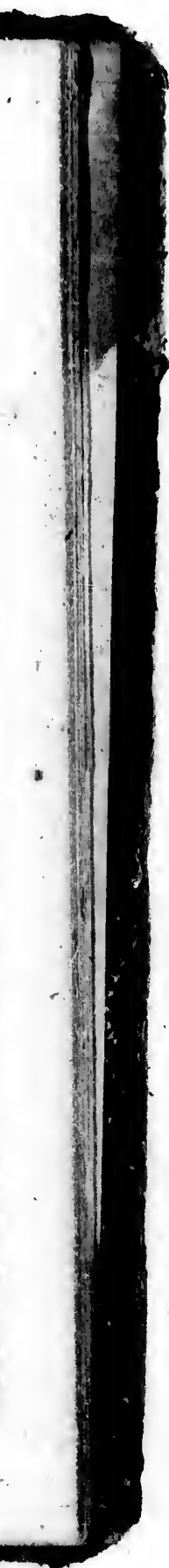




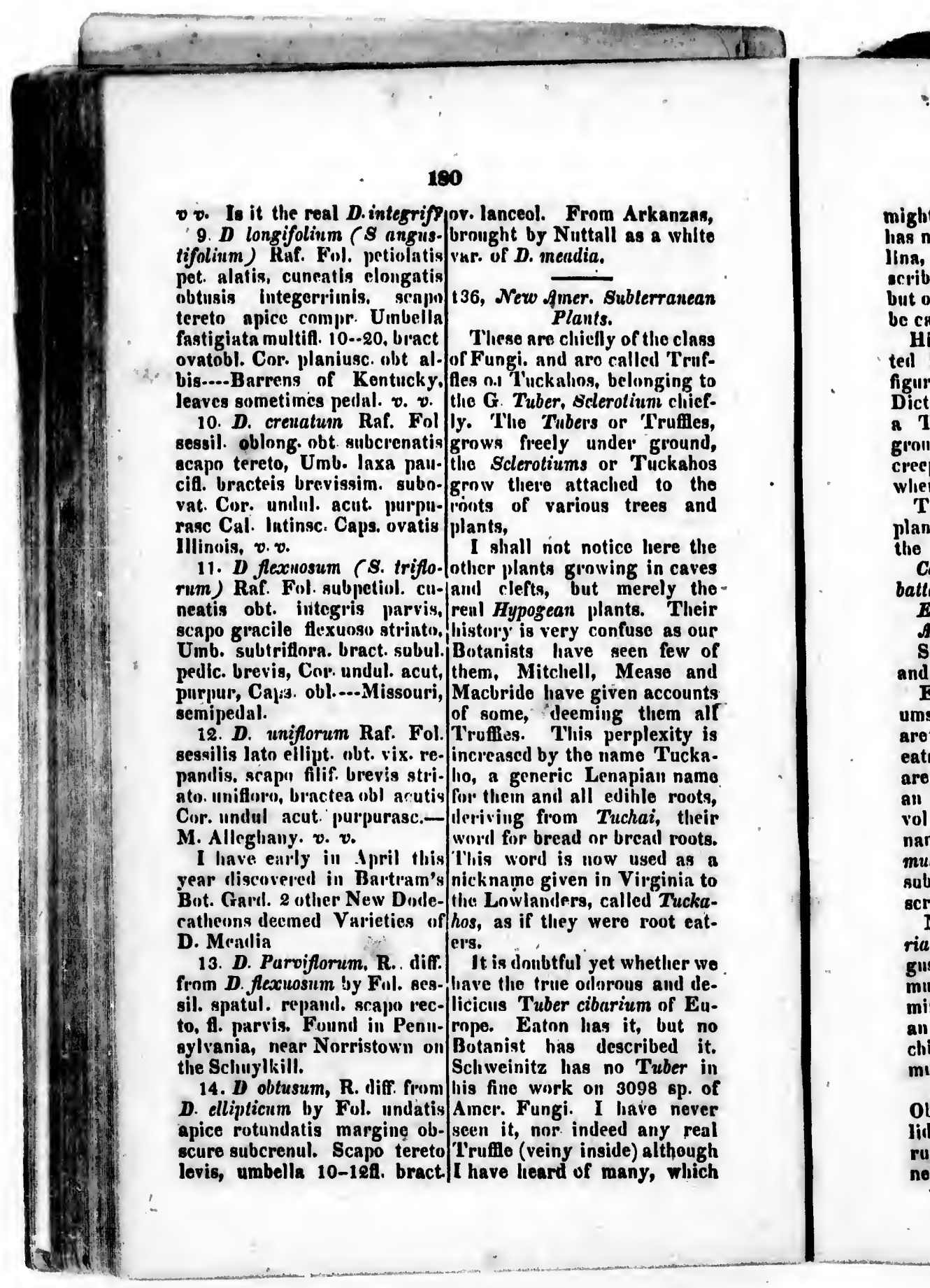


181

might be of different G. Bosc, synon. Lycoperdoides of lias mentioned onte frnin Caro. Claytou arcoidling to. Maclina, which he lias liarilly ile. lurifle, in $\Lambda \mathrm{m}$. M. Mag. N. Y. Jina, which he ithite, inollorous. No. 3, 1. 149, who guve a long irriber, it ls white, hond may account of it. He snys. that be called $\Gamma$. caroliniana. it grows from $S$. Cavilina to His N. G. Uperhiza, omit-Maryland, In all kimls of tell by all our Botanists! is grnunil except Swamps; In figured and described in the N. Fich grounds it grows from 15 Dict. Hist. Nat. It resembles tn 40 llis weight. When young Dict. Hist. Nat. It rews alowe it is nttarlied to the roots of ground. and has the roots Onksand Hickories, but when groming on tho surfuce, wld is quite free. The inside crecping on tho surfuce, wat is quite free. The of modified whence the name. The ronts of the rollowing infibrine! The Indians eat it, but plant.s are calleel Tuckahos inf it lias no smell and little taste.
the Soutliern States.

Convolvules panduratus, C. I saw it in 1817 at Dr Mitbattatas and C. macrorhiza. Erythrina herbacea.

Apios tuberosa.

Raf. oblong knobly mass, Several Sp. of Sagittarialinside white fungose with and Belianthus. chinks, nutșide fulvous smooth. Eaton has only 2 Scleroti- In Carolina, 6 to 12 inches ums, Schweinitz has 22, they long. epiderm thin, gemmules are all Tuckalios, although not small roumled nrticulated in eatable; but the new Tuckahos the hollows. Edible good, ineatable; but the new subterranc- oulorous, scen alive.

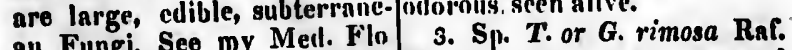
ail Fungi. See my Mel. Fis Mass oblong cuneate nne cud vol ii. N. G. Tucahus. The attenuated, inside white solid name is too barbarnus, Gem. attenuated, inside white solid mularia or Rngosaria, mere de- thick longitulinal flexuose substituted. Ihem.
scribe 4 of them.

N. G. Tucahus or Gemmula. Virginia anil N. Carnl. lately ria. Raf. Subterranean Fun- cominunicatel by Dr Mease, ria. Raf. Souterrats, shape, who received it from Mr Garguitiform or amorphous, for-- net of Jerusalem. First menming a solid mass, coverel by tioned as a nameless Truftic ming a solit mass, wrinkles or by Dr Mitchell Mell. Repns. ais epidermis which sprout gem-1812. It grows in ricli swamps, las no smell nor taste, but mules reproducing the plant. has 1 Sp. 'T. or G. rugosa, Raf edlible, when fresh a little acrid
Oblong mass. inside white, so- and astringent, usell by Indiany licl, with chinks, outsile brown for diarriea. The interual rugose by anastomoted promi- substance has a flexuose breakrent vierves.

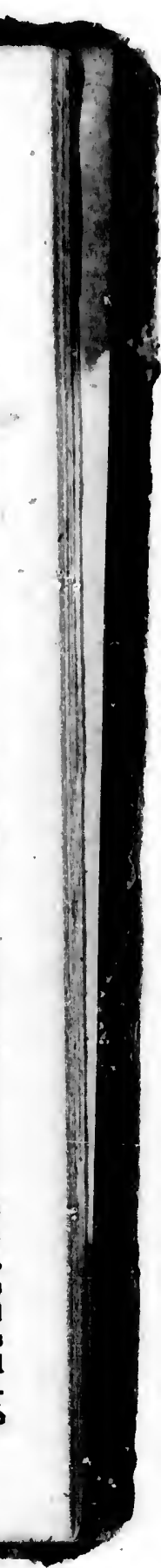




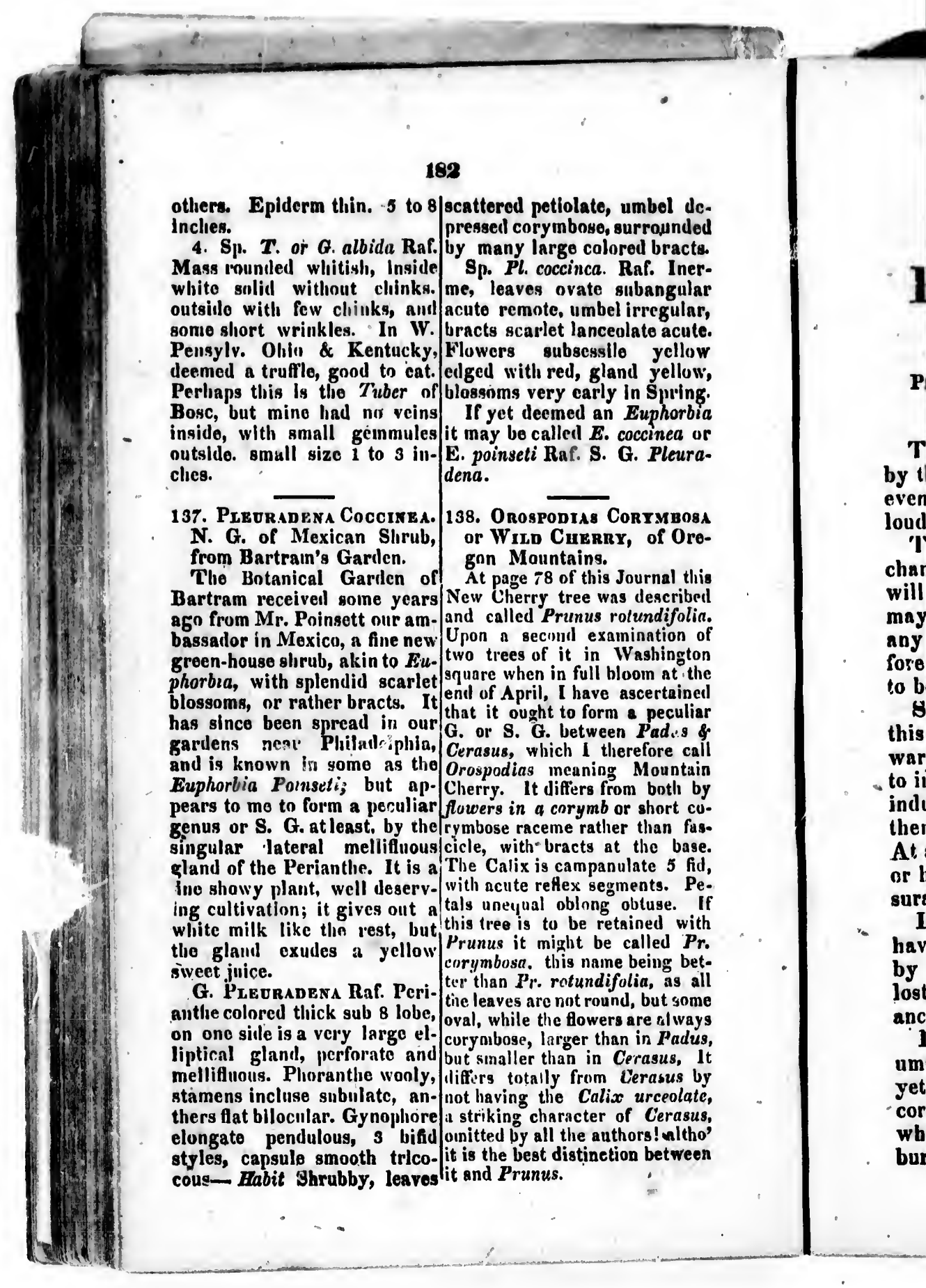




\section{3}

INCOMBUSTIHLE AROHITEOTURE, Ur Fire Proof Buildings of all Kinds,

\section{BUILT AS CHEAP}

\section{AS ANY COMBUSTIBLE BUILDINGS.}

BY C. S. RAFINESQUE,

Profesgnr of many Sciences, Architect, Draftsman, \&cc.

The constant ileplorable loss of property and lives by the conflagration of public and private buildings, nud even whole towns all over the United Stutes, ralls loudly for a remedy or a change in our stylo of louilding.

'This remedy is foumd, and the only ohjection to $a$ change by the greater expense of fire-proof huildiugs will be obviated by the discovery that such buildings may be constructed on a new plan quite as cheap as any other common stone and brick buildings. Therefore this new style of Incombustible Architecture ought to be immediately adopted for all our new buildings.

Several additional advantages are connected with this new style of Architecture, such as enabling to warm the buildings at one third the usual expense, and to insur's then for a mere trifle. Nay, these additional inducements are of such importance that they might of themselves decide to employ this new way of building. At any rate, I am reaily to contract to build any edifice or house, for the payment of the saving in fuel and insurance, besides the actual cost in the usual style.

Let us reflect that ever siuce 1800, the United States have suffered a loss of fifty millions of lohars at least by conflagrations, besides several thousands of lives lostalso; with many millions for wasted fucl, insurances against fire, keeping engines, hoses, and firemen.

Let us reflect that all our colleges, libraries, museums, public offices, stores, factories, theatres, \&c. are yet liable to be destroyed, with all their contents, records, books, wares, machinery, \&c. and julging from what has already happened, they are all doomed to be burnt down in succession, and the contents lost. 


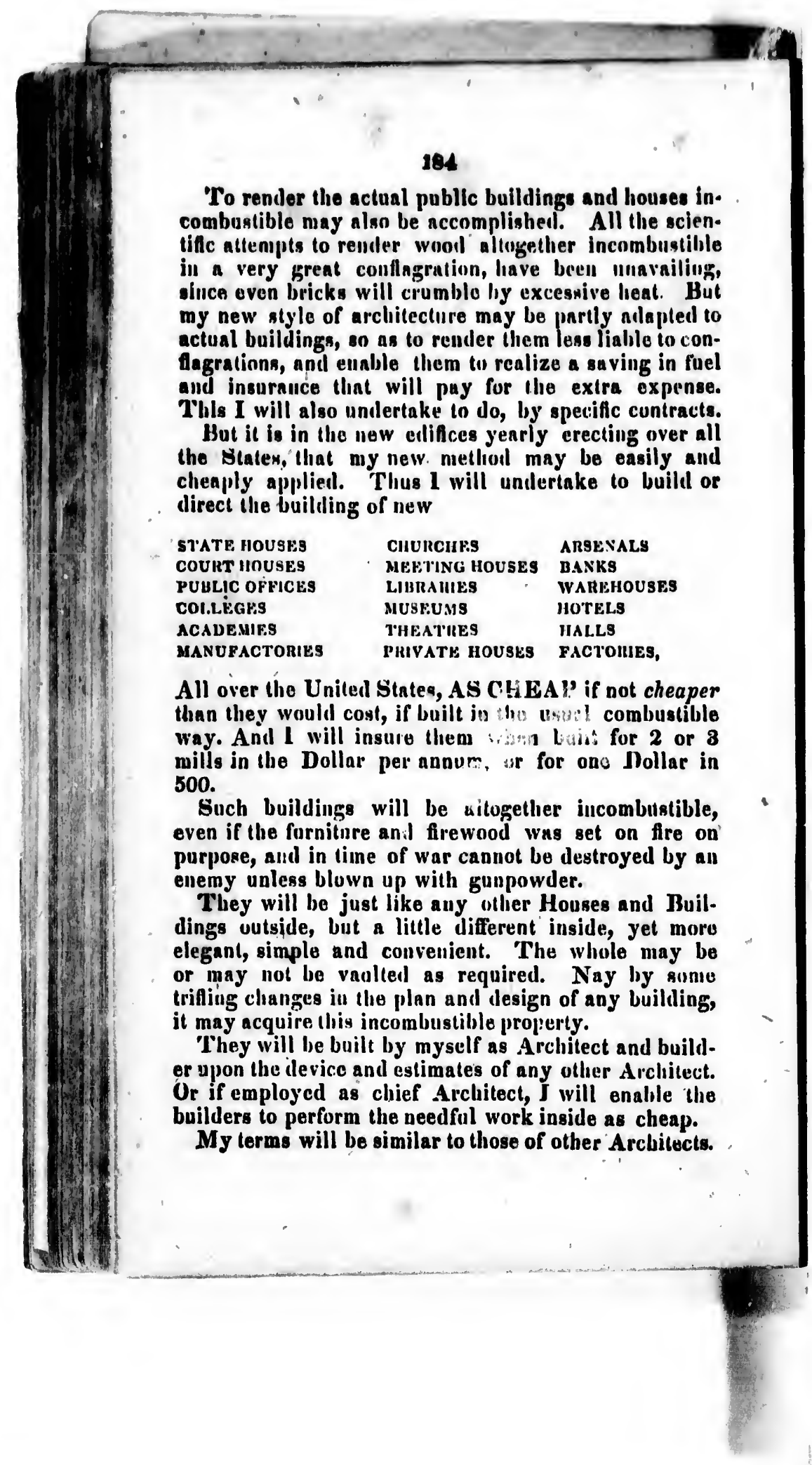




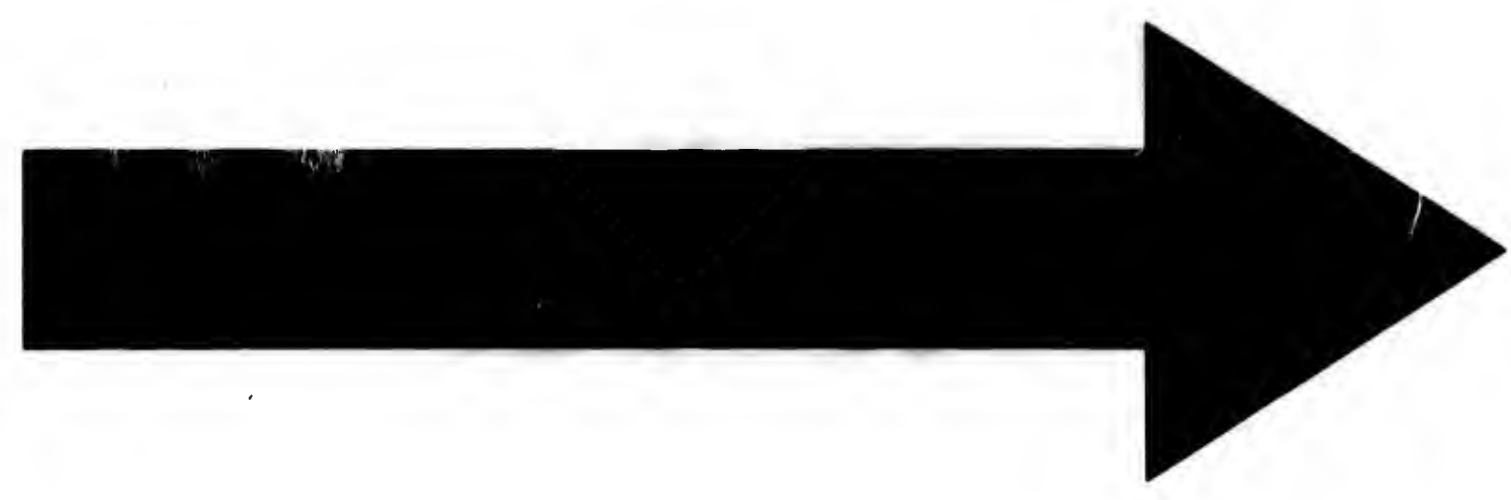




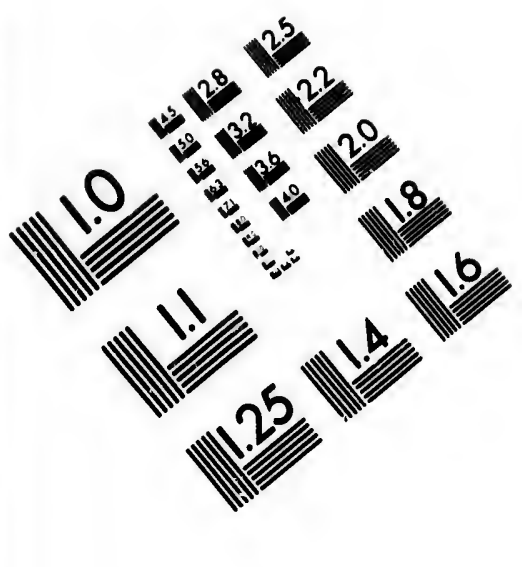

IMAGE EVALUATION
TEST TARGET (MT-3)

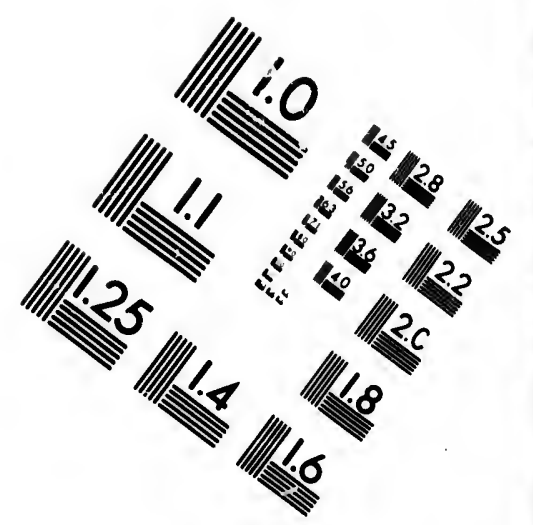

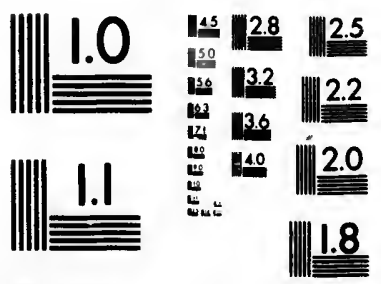

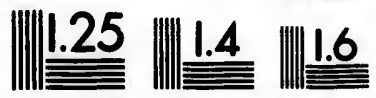
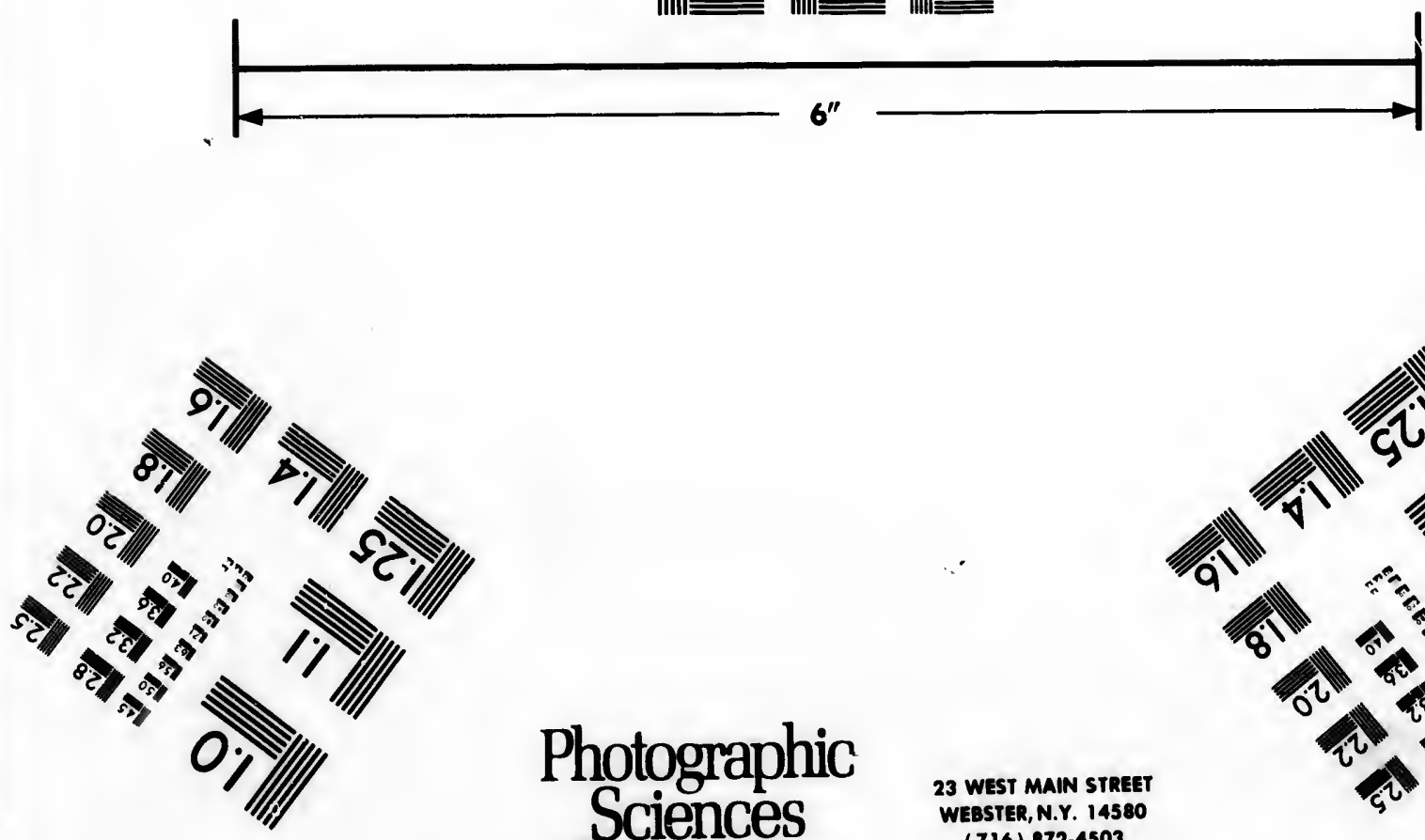

Photographic Sciences Corporation

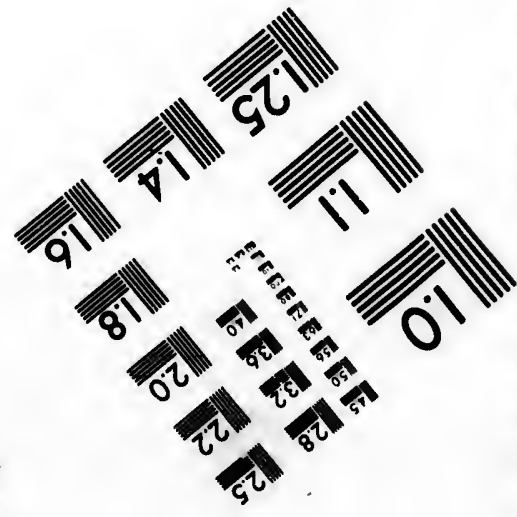




\section{CIHM/ICMH Microfiche Series.}

\section{CIHM/ICMH Collection de microfiches.}

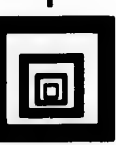

Canadian Institute for Historical Microreproductions / Institut canadien de microreproductions historiques
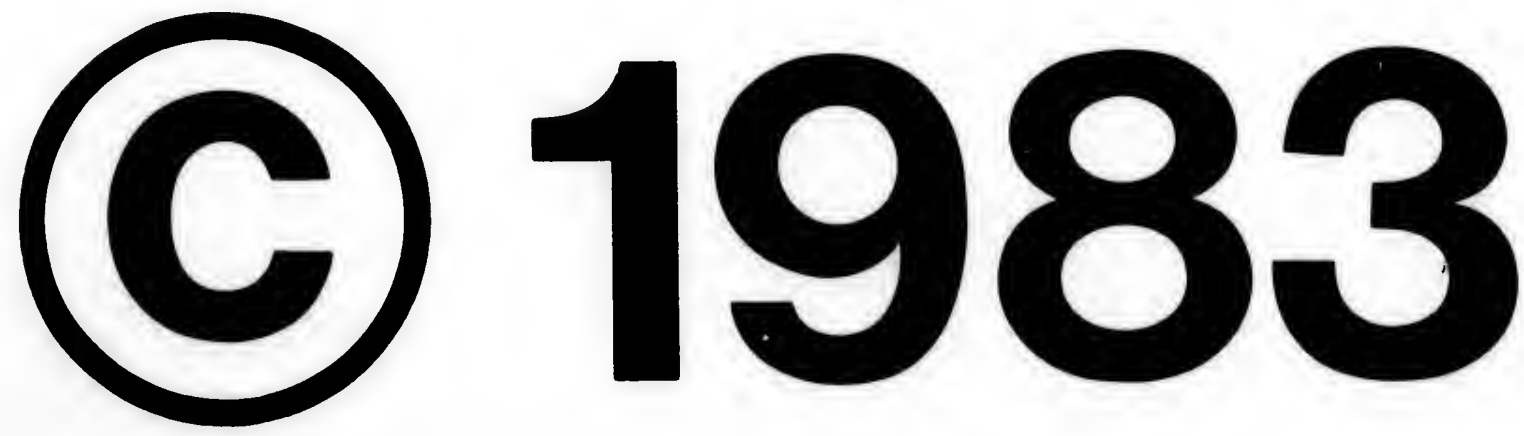
I wi if en and

adve

If

bric

fuel

$\mathbf{T}$

this

neei

the

in a

II actu

suit:

very

by

also

ada

Arc

Let

$\operatorname{tanc}$

tion

peri

pla

and

coo

'] 
$I$ will charge 5 to 10 per cent and travelling expenses if emplnyed as chief architect, but nothing for drafts and estimates. Uf this 2 per cent must be paid in advance.

If enployed as builder I will build at the sane rate as any other builder would for combustible (stone or brick) houses, receiving for remuneration the saving in fuel and insurance for 25 rears, one fifth in advance.

To alter any standing liouse or building and give it this incombustible property, I will cliarge the actual needful expences to change the inside and roof will the saving in fuel und insurance for 10 years, 2 years in advance, or lialf of tlee saving for 25 years.

I have not taken a patent for this discovery, hecause nur nctual patent laws give no security against vexatious law suits and heavy expenses, while by keeping secret a liscovery it may be made more profitable. 'This 1 lanve found by experience. The difficulty of making models would also be tongreat. But I will use this discovery : Macadam used his roadmaking in England, and I will teach the art to any architect or builder for $\$ 1000$.

Apply personally or by letter to $\boldsymbol{C}$. S. Rafinesque, Architect, \&cc. No. 59 North 8th Street, Philailelphia. Letters ought to be post paill unless enclosing remittances. I will not answer any letter asking idle questions; uuless a fee is sent; but will immediately attend to orders in the line of this business.

\section{S. RAFINESQUE,}

\section{Philadelphia, 1833.} Prof. of Hist. \& Nat. Sciences.

\section{Directions how to proceed for Applications.}

Any house owner who wislses to render his pro. perty fire proof, must furnish mo with an account or plan of it, with statement of value, fire insurance, age and cost of fuel in it. Whereupon I will furnish the means (or do it myself) to render it incombustible, and at the same time much warmer in Winter and even cooler in summer.

'Those who wish to put op new buildings, public or 


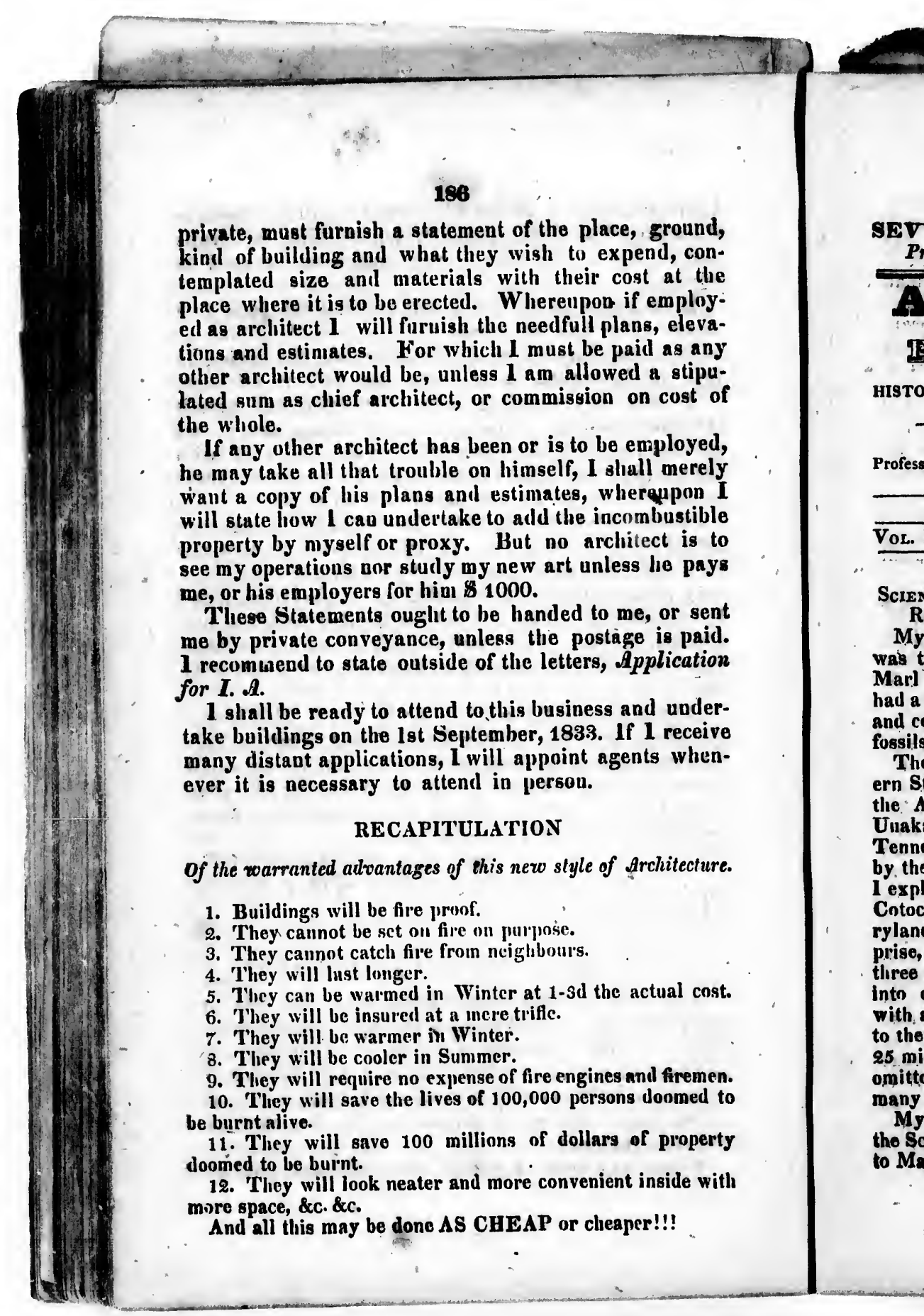




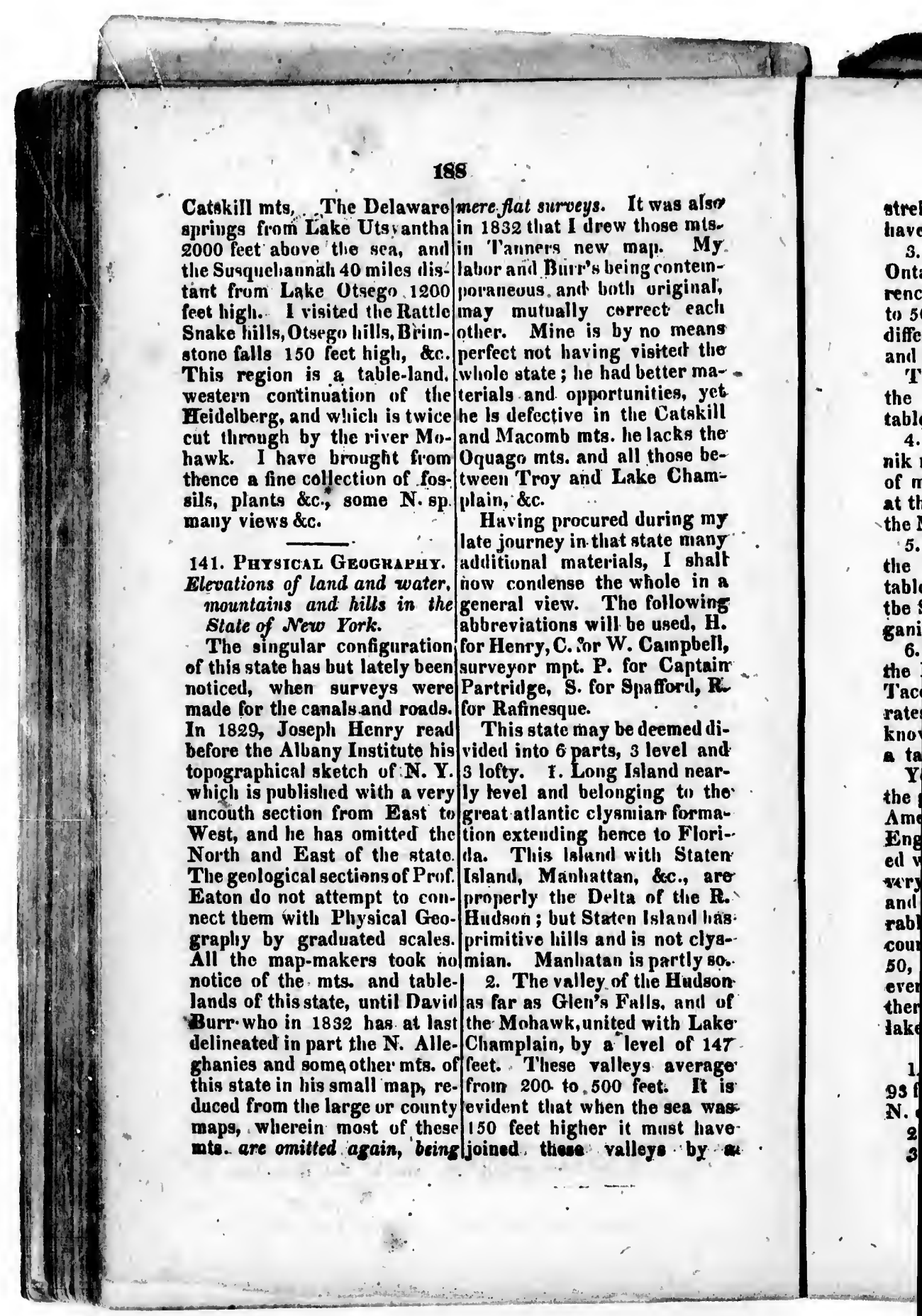


189

strelght, and all E. of It must/ The Lakes of the Alleghany. have been a large island. $\quad$ 1. L. Otsego, head of river 3. The plains along Lake Susquelianah 1200 feet, $\mathbf{R}$. Ontario and the R. St. Law- 1193, H.

rence, which average froin 300 . 2 . L. Utsyantha small, head to 500 feet also, but are of a of Delaware 2000 feet, $R$.

different nature, mostly organic $\quad$ 3. L. Chatauque, head of Alanil liny.

Those 3 level tracts divide 4. 'Tlie two lakes on Catskill the other 3 high regions or $\mathrm{mts}$. $2200, \mathbf{R}$.

table-lands of the state.

nik regiou to the East, a range 7. Beaver L. 1704, H.

of mts. running N. and S. but 8. Lime L. 1623, $\mathbf{H}$.

at the end turning W. to form 9. Cronked L. 718, H.

the Manhattan highlands. 10. Canandaigua 668, H.

5. The Alleghany Region, 11. Seneca L. 447, H.455, C. the largest of all, forming a 12. Cayuga L. 387, H.415, C. table-land 360 miles wide in 13. Skeneateles L. 752, H. the S. of the state, and of or-'These 5 last lakes are on the Nanic formation. slope of the Alleghany.

6. The Saranac Region, to 14. Tully Lakes, 1194, H. the North, primitive like the The lakes of the 3 low reTaconic. L. Champlain sepa- gions have no great elevation, rates them. It is the least except Oneida, 375 , and Ononknown and explured, but also dlagua 361 . Cross L. 370, $\mathbf{H}$. table-Jand. Those of the Taconic region

Yet the whole state lies in are all small. Those of the the great Lake region of North Saranac region are numberless America, extending from N. but unmeasured, except Lake England to Alaska. It is filk-George 336 feet, $P$. those at the ell with lakes, of which 3 are head of R. Saranac and Hudson very large, 20 of middle size, are about 1000 feet.

anil the small ones are innume-- 1. Region, Insular, highest hills. rable, perhajps 2000. A single Hempstead hills L. Id. 319, $P$, county that of Delaware has Tompkins hill, Staten Island 50, another 100. 'They extend $307, P$.

even to Long Island. I will Closter mt. Mandattan Id. therefore begin with those $539, \mathrm{P}$.

lakes.

The 3 Great Lakes. $\quad$ Cepitol of Albany $130, \mathbf{H}$,

1. Lake Champlain lowest, 126 , C. West Poinx 188, P. 93 feet above sea at head, 50 at Kingston 188, H. 198, C, N. end.

Warwasing 31, C. C.

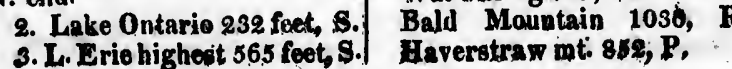

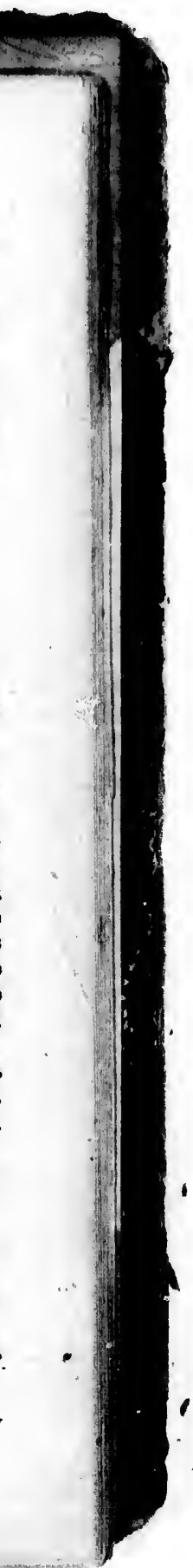




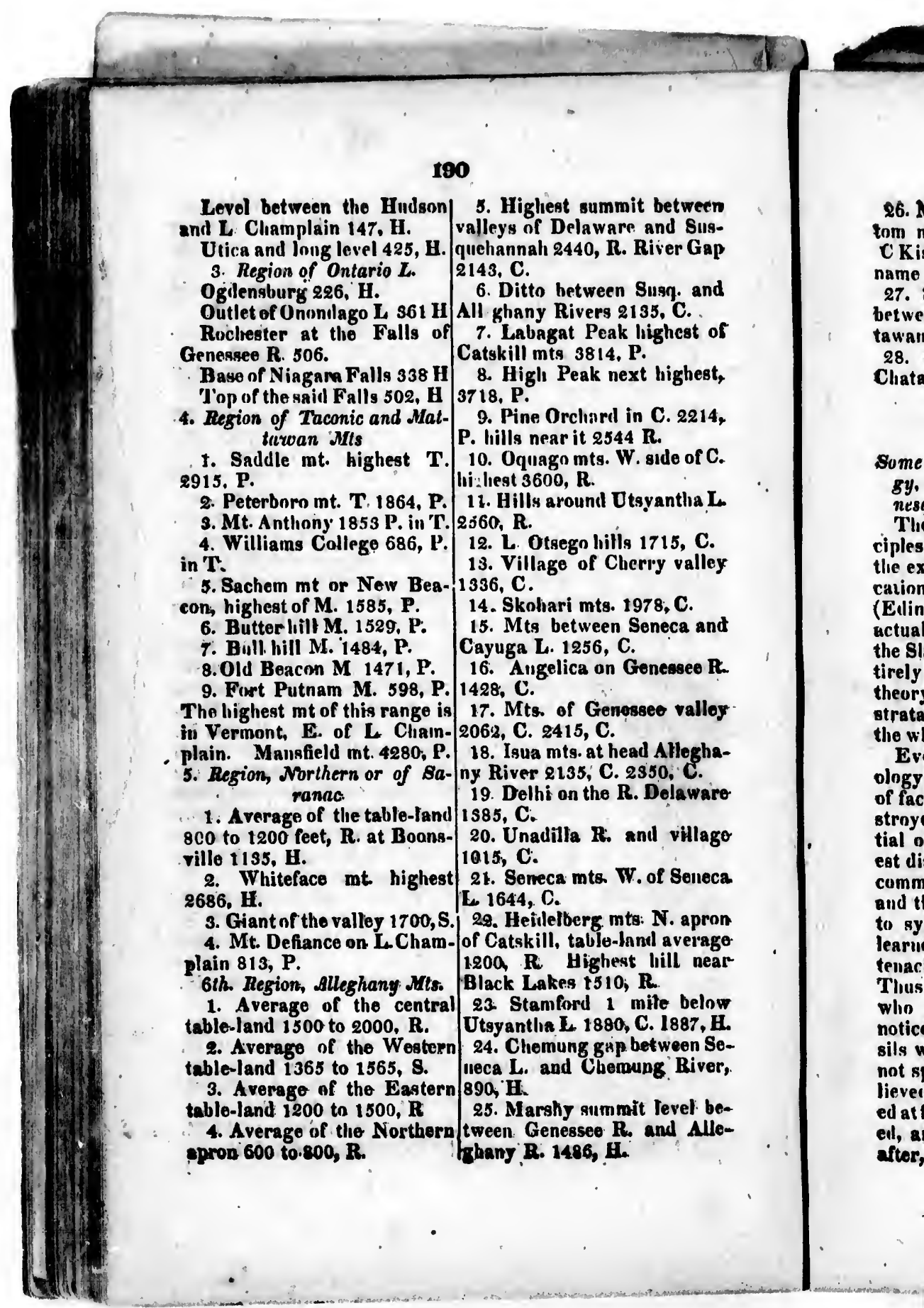




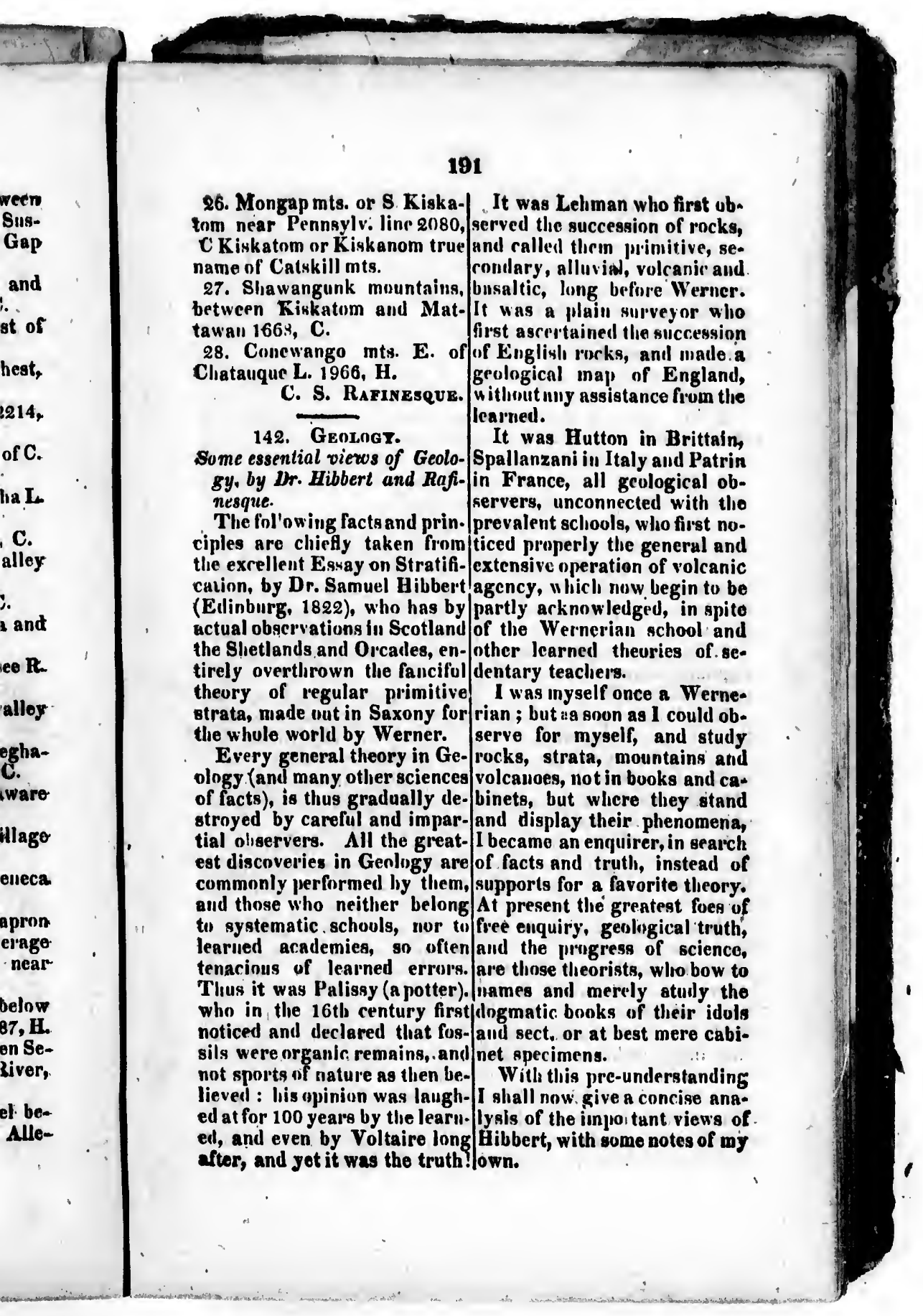




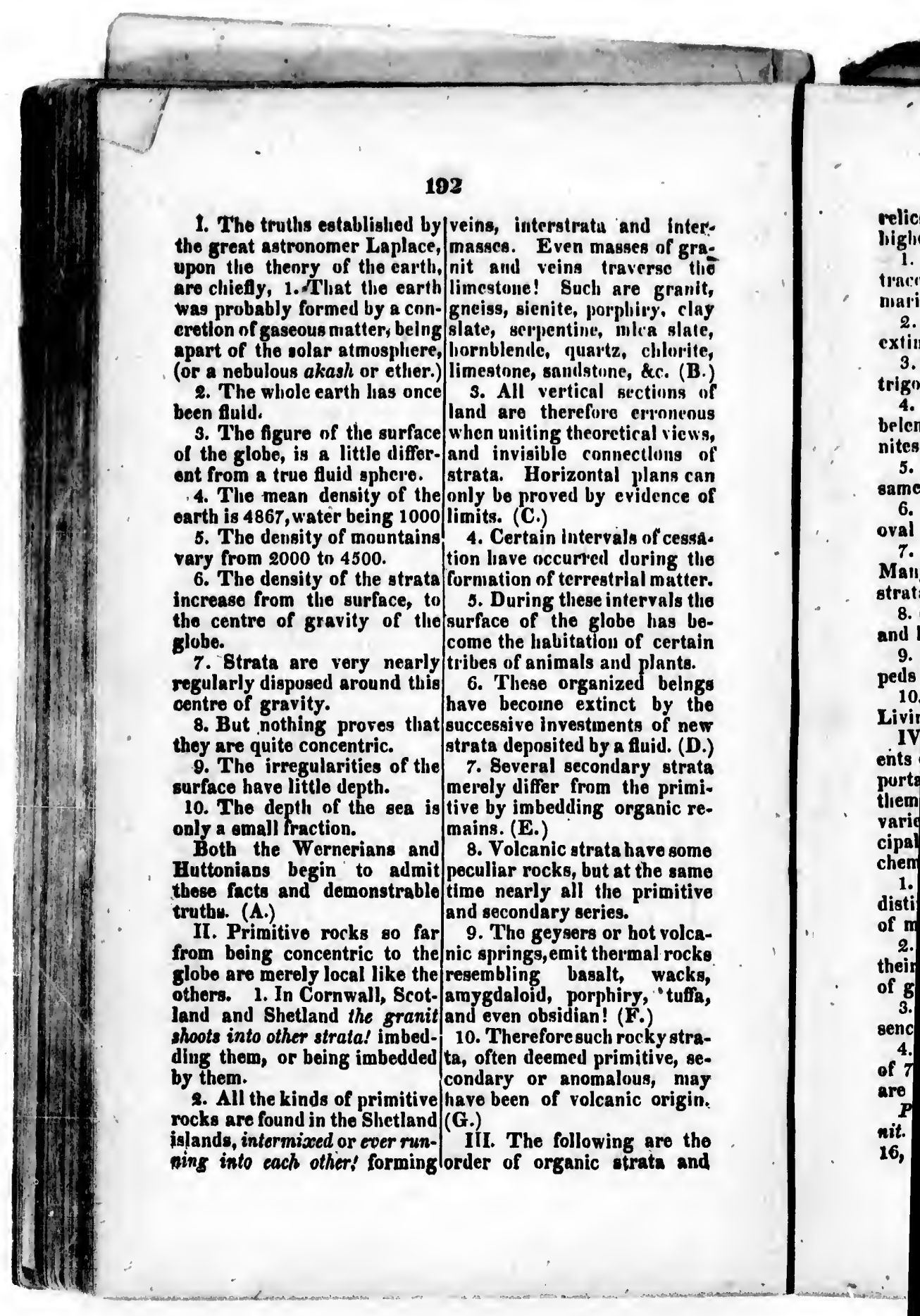


193

velics, from the lowest to the 2 , adventitious 4 parts out of higliest. 100.

1. Oldest or lovest. With coal Primary transition. Silex 58, traces of vergetation and a fow lime 16, aluninc 14, magncsia marino animuls. (II.)

2. Cubscal limestonc. With gypsum, bitumen. \&c. 8.

extinct encrinites. (I.) Secondary. Silex 56, lime 24,

3. Lias. With ammonitcs, alumine 12, adventitious, gyp-

trigonites, pentacrinites, \&a. sum, salt, iron, \&c. 8.

4. Sundstone and Grit. With Tertiary. Silex 52, lime 32,

belennites, ummonites, trigu-alumine 10, adventitious gypnites, \&c.

sum, \&c. 6.

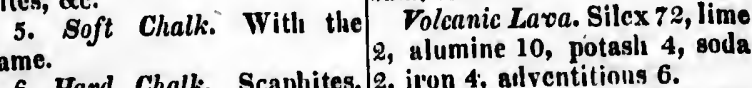
same.

6. Hard Chalk. Scaphites, 2, iron 4, aulventitious 6.

oval ammonites. Blue Clay. lex 60, lime 2, alumine 24, so.

Mainy sliells not found in older da 8 , iron 2, adventitious 4 .

Maily sliells
Basalt. Silex 48 , lime 8, al-

8. Gravel. With recent sliells umine 8 , iron 18, soda 4, ad-

and lanil animals.

9. Gypsum. Extinct quadru- V.-The natural ingredients

9. Gypsum. Extinct quadru- of rocks and strata : or sucpeds and birds.

10. Diluvion and Alluvion. lessive arrangemed and matter, may be comprized un-

IV. The cliemical ingredi- der 6 series.

ints of rocks are of great im- 1st Series. Molecules. They portance in distinguishing are the chemical ingredients them. Although liable to some enumerated above.

variety and anomaly, the prin- $2 d$ Scries. Particles or granvariety and anomaly, to agree in ular parts. They are of 4 kinds, cipal series appear to agree in 1 crystaline, 2. porphyritic, chemical composition. 1. The primary rucks arentaline, 4. arenaceous. distinguished by the presence 3 3d Scries. Concretions. Of 8

of magnesia and potash.
2. The organic rocks by kinds, 1. crystaline, 2. porphytheir absence, but the presence ritic or cricical laof gypsum and excess of lime. crystaline, 4. concentrical 6 . ir3. The volcanic by the pre- minar, 5. amygdaloid, 6. sence of soda and iron. 4. The arerage ingredients fragmentary or conglomerate,
8. organic, containing imbedof 7 scries of important rocks, $\begin{aligned} & 8 \text {. organic, containg } \\ & \text { ded organic remains. }\end{aligned}$ are as follows.
Primary Series, chiefly gra- 4 th Series. Masses or Masmit. Silex 60, lime 8, alumine sive portions. Of 9 kinds, ac16, magnesia 6 , potash 4 , iron|cording to structure, 1. lami-

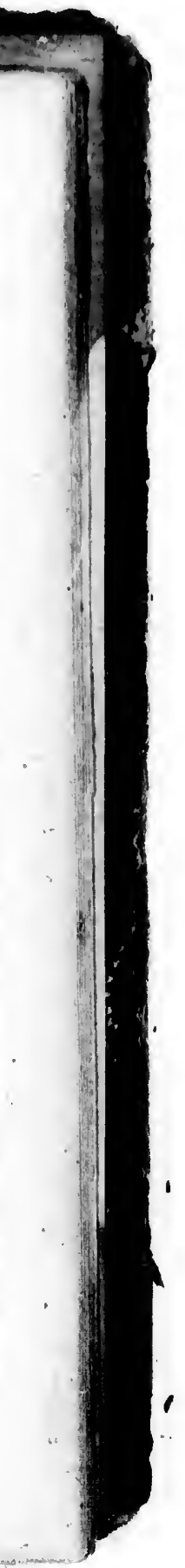




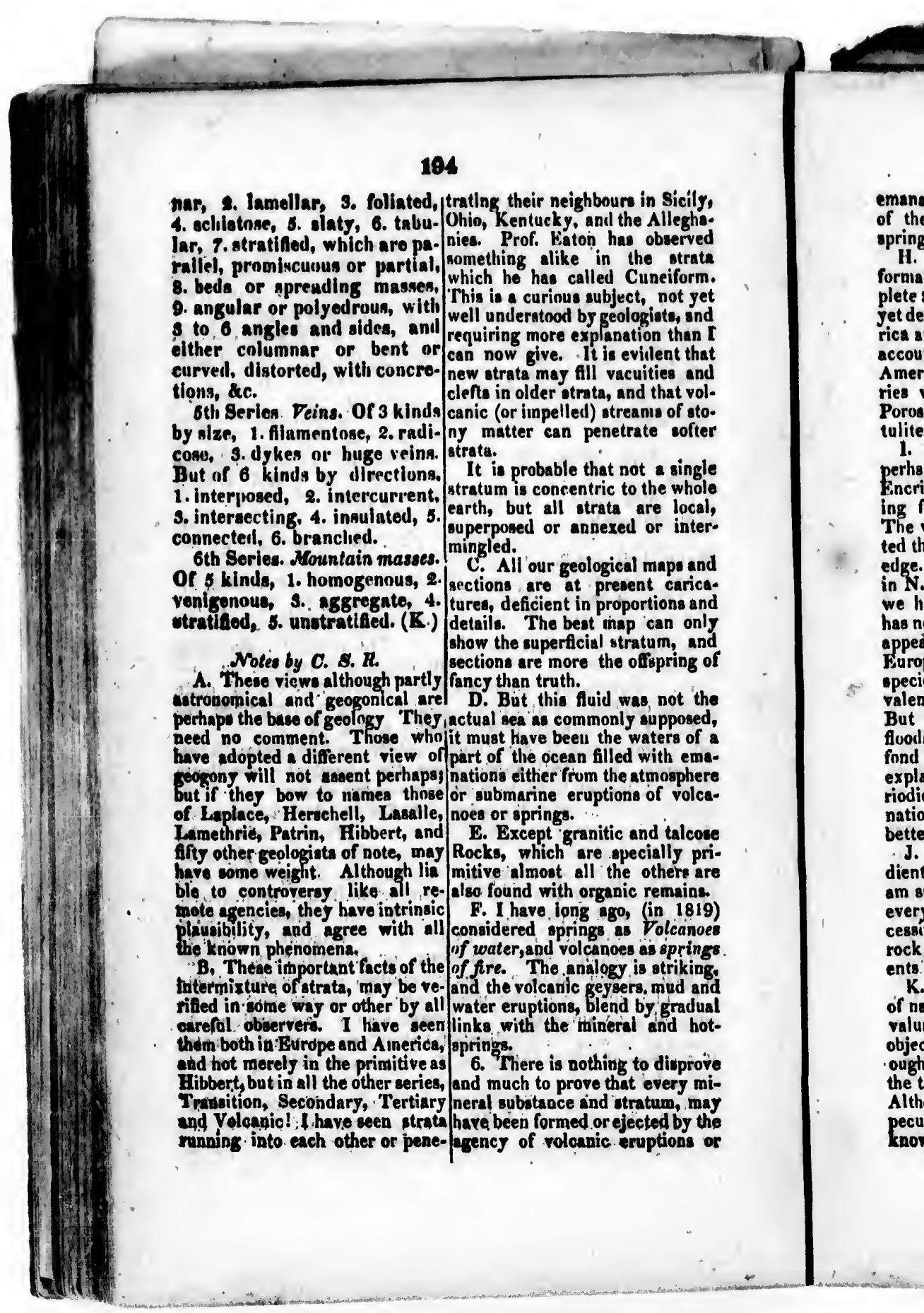




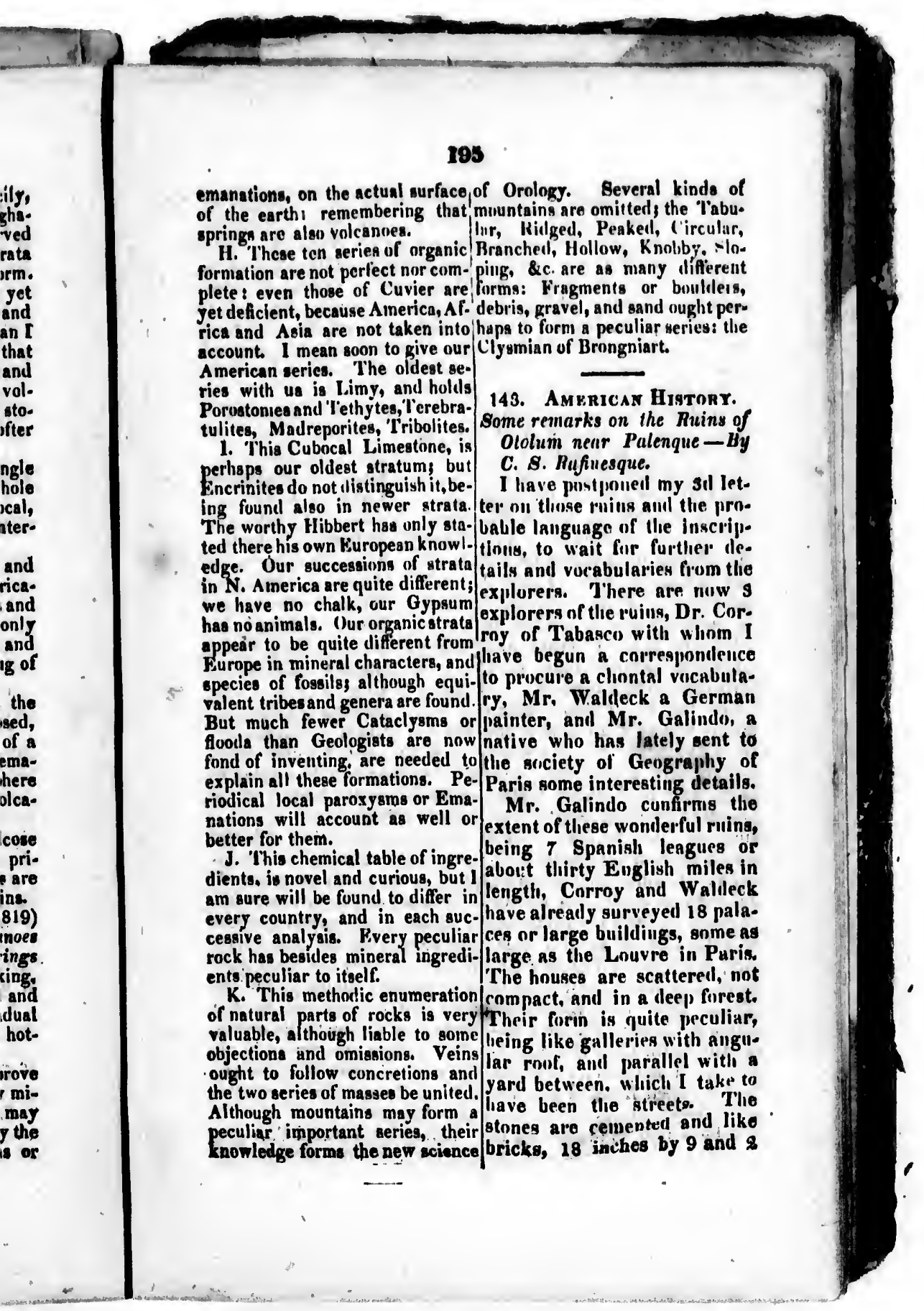




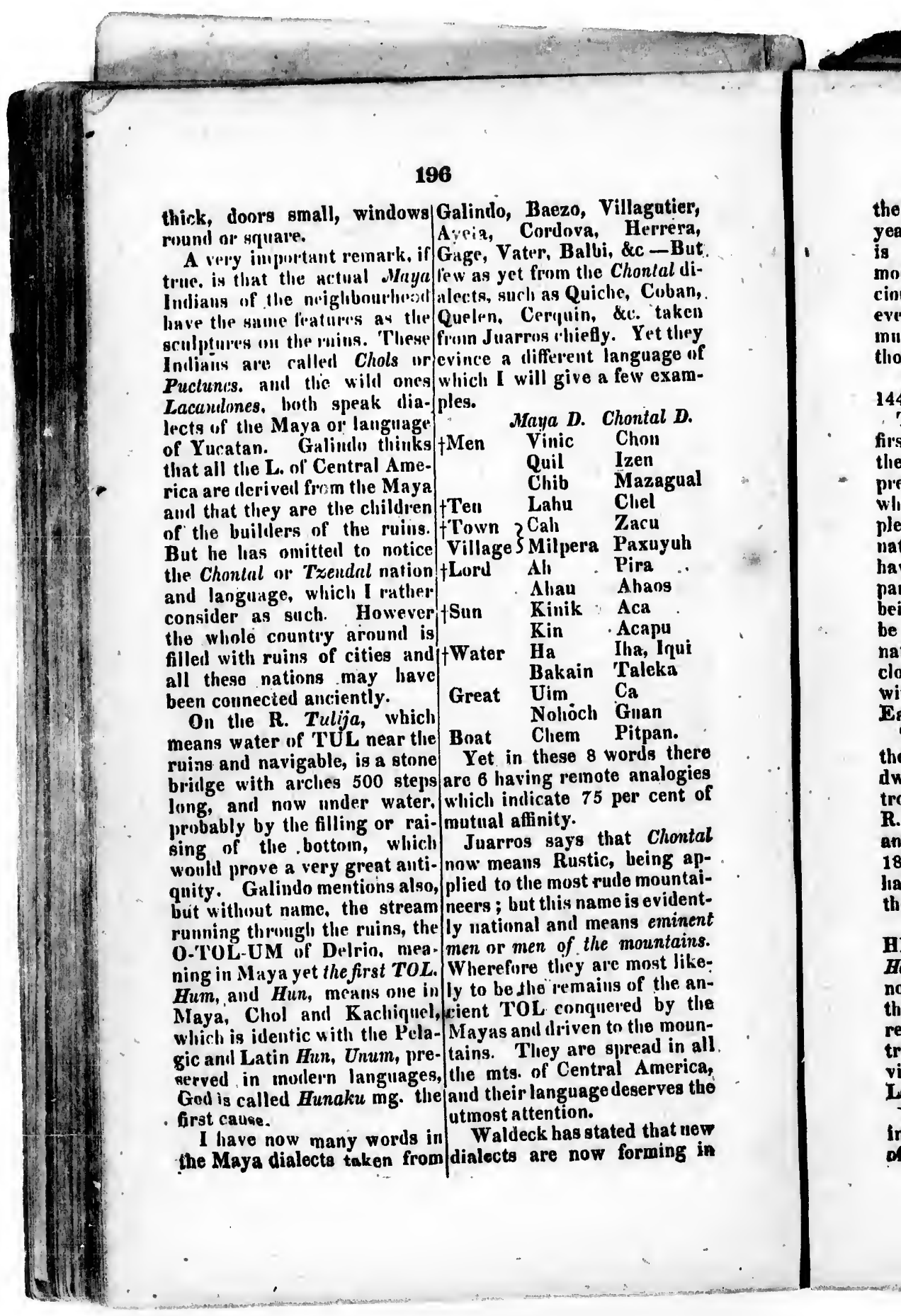




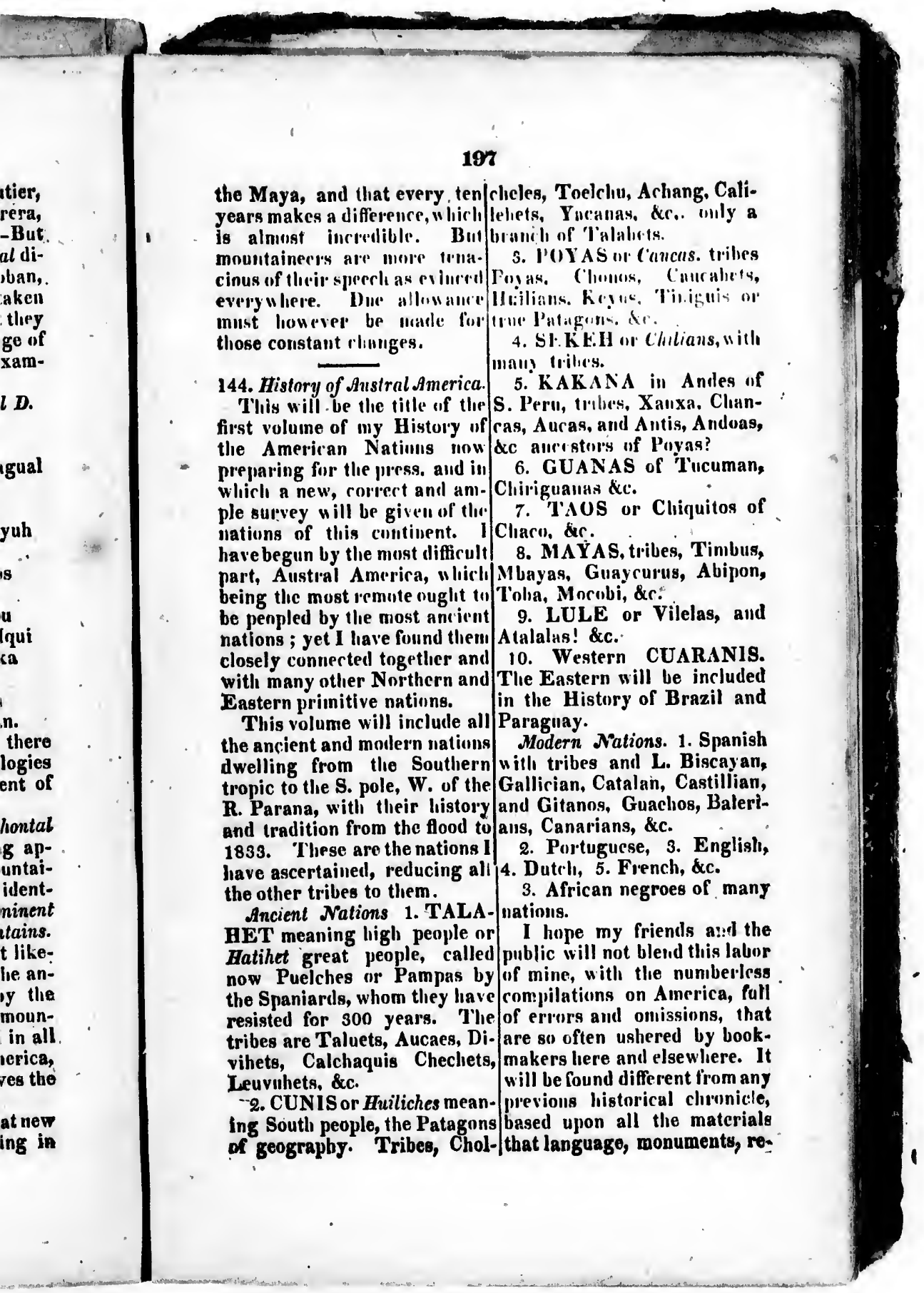




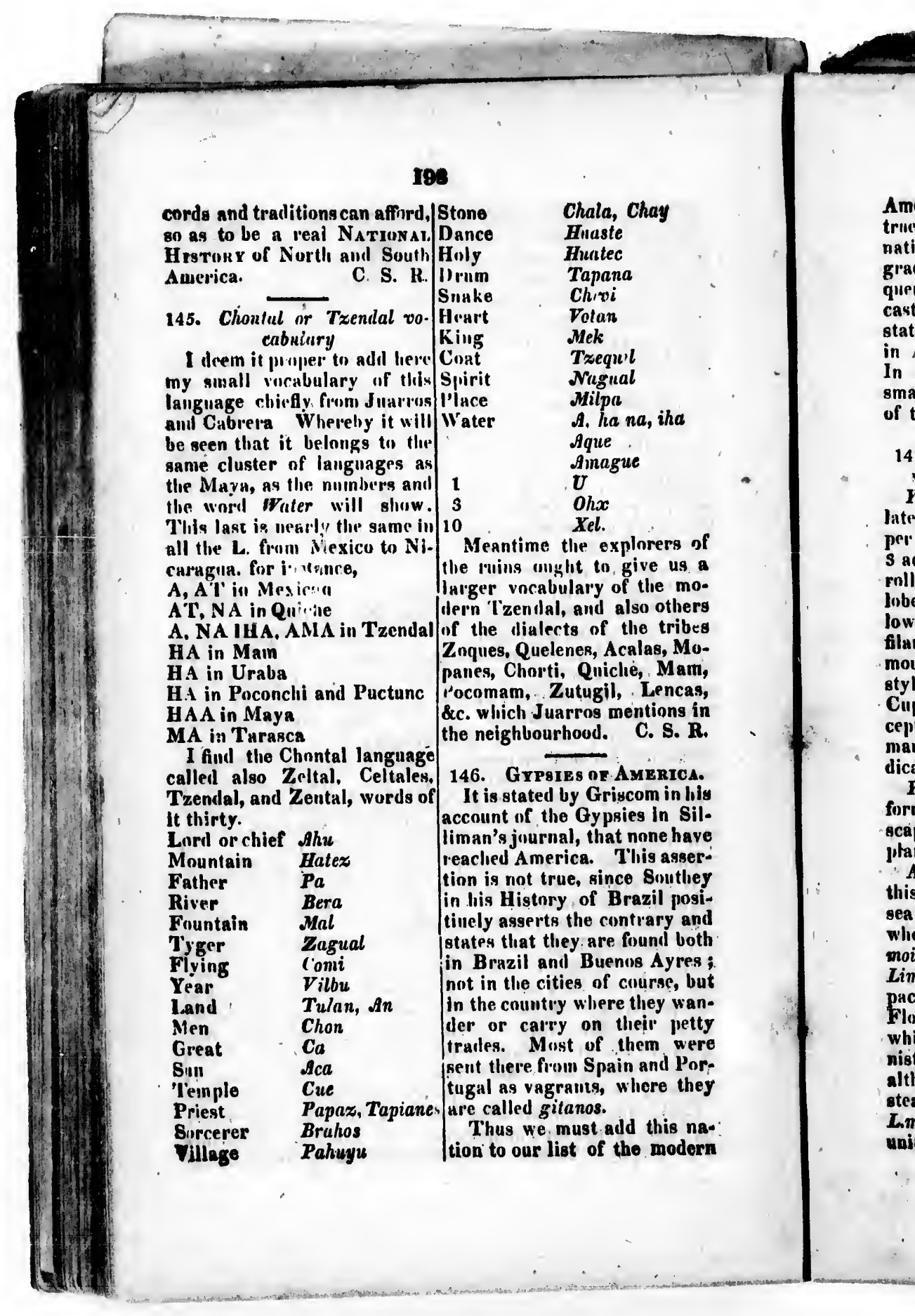




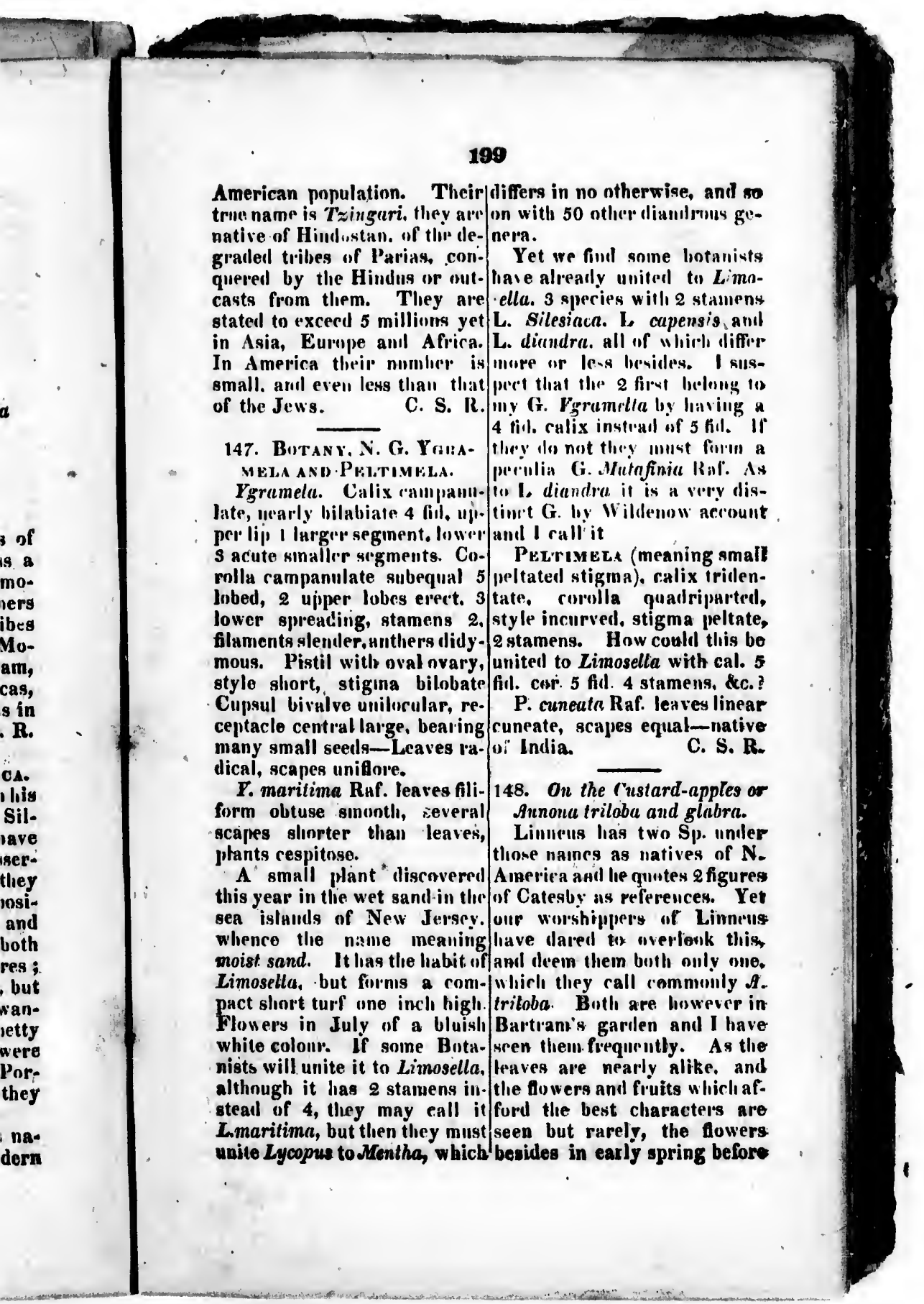




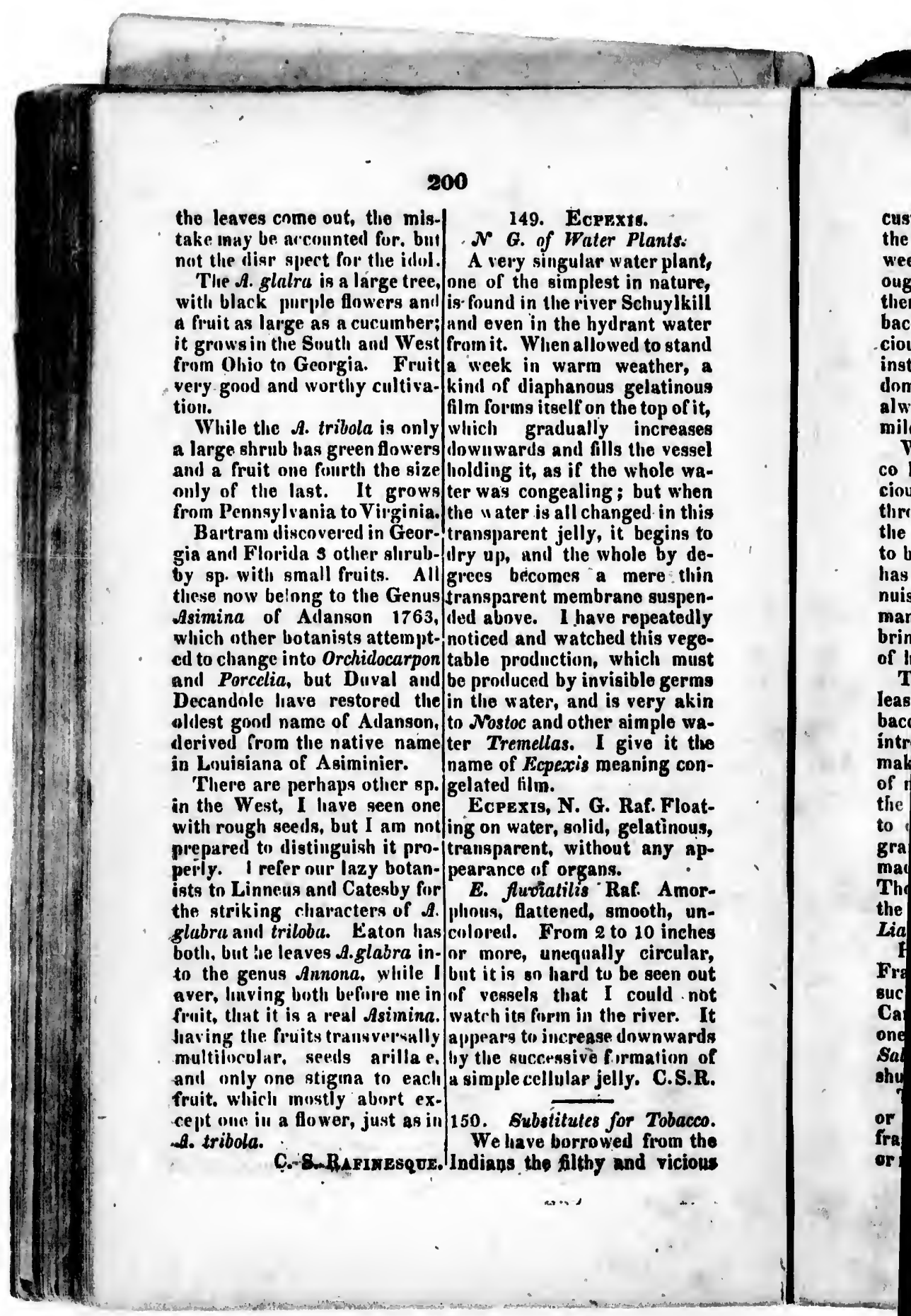




\section{1}

custom of smoking, or inhaling in cigars. Many other leaves the hot vapor of a pernicious are cqually good, such as sweet weed, a narcotic poison. We fern, wintergreen, and many ought at least to borrow from more which I shall indicate if them the mode of making To-any disposition is evinced to bacco milder and less perni- leave off the strong stinking cious, and above all fragrant tobacco. This fragrant substiinstead of stinking: they sel-tute could be afforded so cheap dom smoke pure tobacco, but that the present smokers would, always mix it with fragrant or no longer be complled to milder substances.

smoke coarse rank cigars.

Whoever smokes pure tubacco habitually, is a selfish vicious man, particularly if he 15t. Huge Water Vulcano. throws the stinking sinoke into One of the higliest volcano the lungs of whover chances throwing water instral of fire, to be uear him; which no onc is found near Guatiunala. It has a riglit to do as it is a leal is a perfect cone 14,500 feet nuisance, as much so as if a high and 72 miles in circuit. man was to throw dust or Dunn who ascended it in 1828 brimstone smoke into the noses gays that the crater which once of his neighbors. threw a fluod of water, is a

Therefore let them adopt at rocky concave hullow, only least firagrant tobacco, the to- 140 by 120 yards; it has now bacconists who will devise and mosses and grasses in it. The introduce them will probably Spanisli call it Volcan de Agua make furtunes and deserve well oir water volcano. The Indian of mankind, as it will Iessen village of $\mathbf{S}$. Maria is $7500 \mathrm{ft}$. the evil done to themselves and high on it. It is divided in 4 to others by smokers. - Fra-lregions. 1. Cultivates or trogrant cigaps might lhus be pical till 9000 feet. 2. Wovily made better than Havana rregion or forest of oaks, witl Those are marle fragrant by canes and the rare tree Cheiros. the leaves of Piqueria or of temon. 3. Naked region of Liatris odoratissima. Here is a recipe for making crowning the top, whele liere Fragrant Tobacco for the pipe is a sublime and extensive view, such as used by the Indians of the two oceans Atlantic and $\mathrm{Pa}$ Caniada, 1-3d tobacen leaves. cific can be seen fiom it. Thie one third leaves of red willow. thermoneter stoond at $42 \mathrm{lleg}$. Salix purpurea, and one third when it was 72 degrees at the shumac leaves. base.

The leaves of the sweet gum It was called $\boldsymbol{U}$-hatez-mal-ha or Liquid-amber, make a very by the Chontals, nieaning the fragrant tobacco by theinselves mpyntuin throwing water, and or mixt, and they can be rolled/has thus been known as such

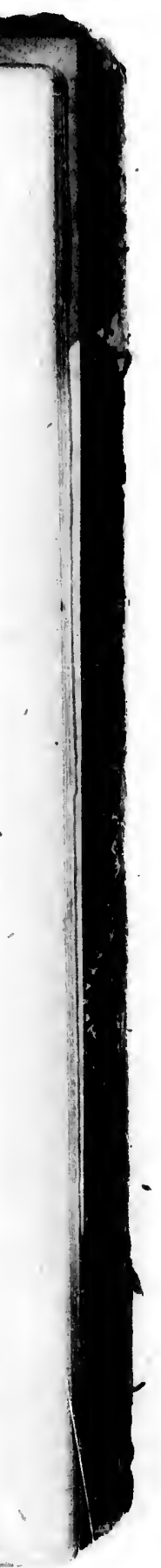




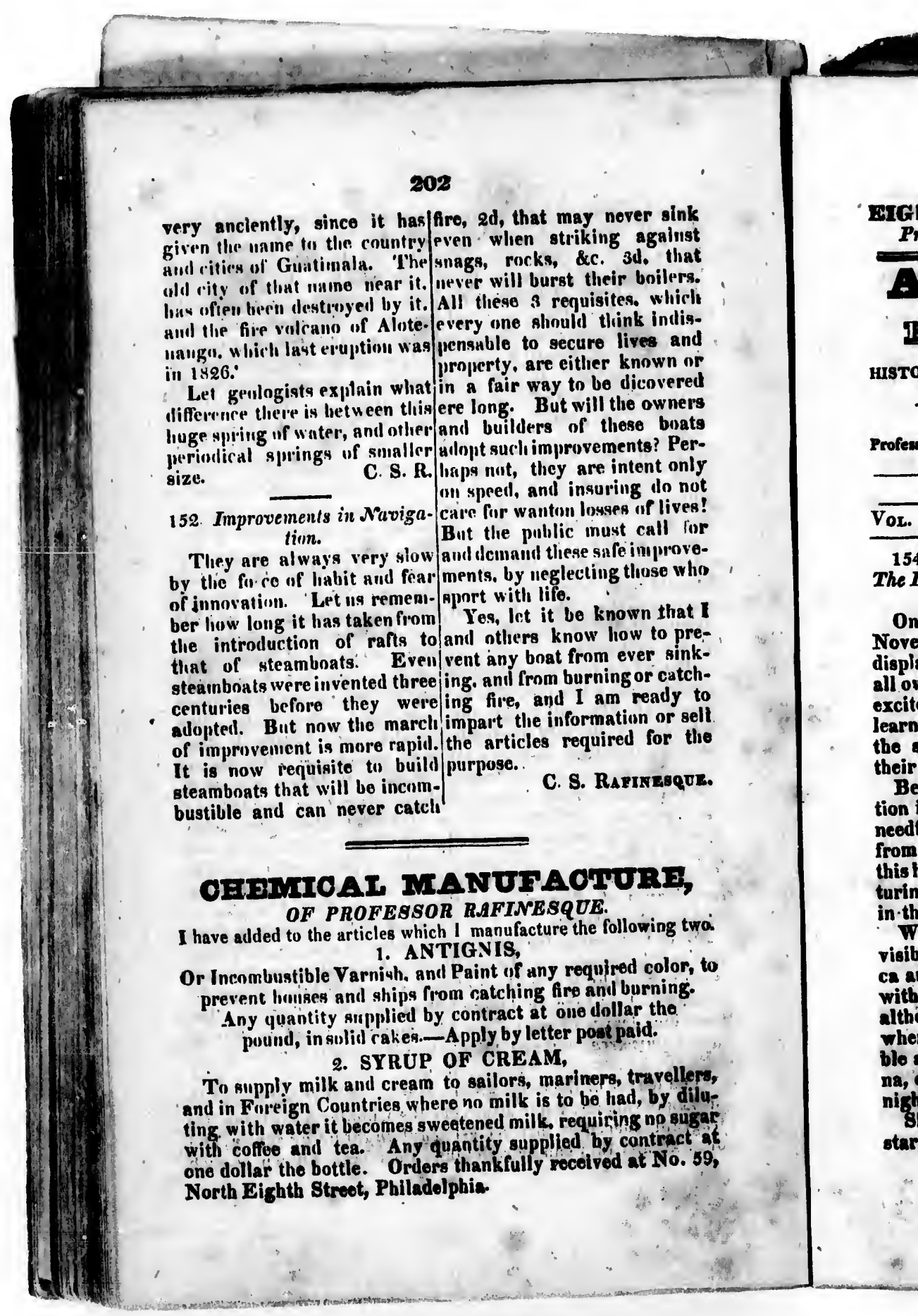




\section{Nr. 8.}

MGHTH NUMBER FOR THE WINTER OF 1833.

Price 50 Cents each number, or ONE Dollar per annum.

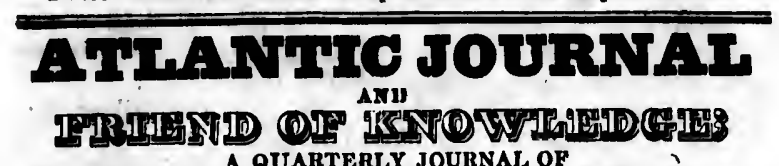

HISTORICAL AND NATURAL SCIENCES, USEFUL KNOWLEDGE, \&C. WITH FIGURES.

BY C. S. RAFINESQUE,

Profeswor of Historical and Natural Sciences, Member of many learned Societies in America and Europe, Author of many Works, \&c. \&ce.

\begin{tabular}{lll}
\hline \multicolumn{4}{c}{ Knowledge is the menta! food of man. } \\
\hline Voi. I. Phicadelphia, Winter of 1833. & No. 8.
\end{tabular}

154. METEOROLOGY. Inon at night, particularly in The Luminous Meteors of 1833. vnlcanic countries; they are By C. S. Rafinesque. probably as common in thie day On the night of the,12 to 13 time, but unseen. The meteors November, 1833, a wonderful of Novembcr (which have again display of metcors was visible appeared partly in some nights all over N. America, which has of Nov. and Dec.) were not the excited the curiosity of the same thing, being compared to learned and unlearned, alarmed a shower of fire-works, falling the superstitious, and baffied rockets, and luminous snakes; their inquiries. clouds, suns and streamg of Before any correct explana-fire, diverging from a circle in tion is attempted, it would be the Atlantic Ocean towards the needful to wait for the accounts horizon all around on our from all parts of the world; Atlantic shores; and in Calithis has proveuted me from ven- fornia as directed towards the turing to write on the subject North.

in the nowspapers. It will be needful for whoever

We know already that it was will attempt a rational explavisible from Canada to Jamai- nation of this phenomenon, to ca and California; but attended have before him the accounts with different circumstances, from all parts of the world, and although simultaneous every to compare them carefully as to where. It may have been visi- time, directions, and appearblo also in Europe and in Chi- ances. If unseen where it was na, or at least, wherever it was daylight, it does not follow that nisht: nighooting stars and flying also, but they may have been stars, are a common phenome- hidden by the solar light. 


\section{6}

It will be needful to ascortain 3. Many moteors were com1. If the moteors were above minglod, come oxploded with the clouds or beneath them, if noise, others did not. sny reached the ground, whore 4. The general motion wae and how? Common thooting radiating from a cirtlo In tho stars reach the ground in Atlantic Ocoan. oblique phoephoric streams.

5. No Aerolites fell or was

2. How high was the region seen to fall.

where they started, or where 6. The eurore borealis apsome exploded? this may bo peared along with them on ascertained by angles.

3. Was their light phospho- $W$.

ric, electrical or enfiamed?

ake Erie or towarde the N.

4. Did not their general mo- the northern hemisphere of the tion move contrary to the eartli.

earth's actual motion at the 8. They did not set sre to time?

any thing, like thunder bolts

5. Was the whole a sidereal and bolides.

or an atmospheric plienomenon? Did it begin out or at the contact of the atmosphere?

Arter this we must discuss what connection there may be between these moteors and the

155. $\mathrm{BOT}$ Chronological Index of the principal Botanical "Works and Discoveries published by $C$. S. Rafinesque.

aurora borealis, al comets, 3 Sous botanical rriters have electricity, 4 the hydrogene of been loath or prevented to renthe atmosphere, 5 volcanic der justice to $\mathrm{my}$ botanical laemanations, 6 arolites and bo- bors and discoveries since 1802; lides, 7 other luminnus moteors they pretend that they do not

trabes, zodiacal lights, \&c. 8 know all my works; yet when common flying stars, \&ce.

Therefore, correct scientific gleet them. Idlciless or jealexplanations will not be easy ousy would be a better pretext. nor speedy. Whatever may be Some European botanists, and said or conjectured, without Decandolle, the first among reference to these needful en- them, have done me better jusquiries, will be mere conjecture tice.

and rain theories.

I will give here a complete

The following facts may be index of nearly all my publica-

1. They were not similar to American plants, in order of common flying stars.

American plants, in order. of

2. They were seen at 4000 discoveries and improvemente miles distance, N. and S., E. They are mostly to be obtainand W. or occupied that im- ed from me, and are embodiod mense space. in my smenitice of Nutive or

coll

say

cap

ro

7

my

trac

dep

\section{cult}

scie

Im

yea

will

time

176

Jone

riva

1

and

firve

Ben

Mu

1
$\mathbf{A m}$
1

Pro

${ }^{1}$.

No

in.

Ob

tar

Pa 
collection of my. tracts and es- 1811. Naturalized plants of says. My N.American botani- the United States, in N0. 56 of cal discoverios will also be re- Medical Repository.

capitulated In $\mathrm{my}$ Additional 1812. Monograph of the G. Flora of N. America. Callitriche. On the Tuber

This index does not contain rufescens of Sicily. On some my works on Zoology and Ani-- new plants and animals. Reform mals, nor some few botanical of some Genera. Pamphlets. tracts, of which I havo been 1814 . Compendium of $\mathrm{my}$ deprived by shipwreck. zoological and botanical disco-

Few botanists have so long veries, 63 N.G. and 116 N.Sp. cultivated and improved the Pamphlet, Palermo. Principles science, since I began in N. of Nomenclature and classificascience, sico America in 1802, and I find my tion, ditto. Panphyton section of 1.25 zeal unabated after above 30 of Cupani, section

years of exertions. My labors plates in folio, Palermo. will be duly appreciated in Cyclopedical Journal of Sitime, those of Adanson of cily, \& vols. 4to. with several 1763 and Necker of 1790 , so botanical essays, $20 \mathrm{~N}$. G. of 1763 and Necker of 1790 atic exotic plants, 15 new Sicilian rivals, begin at last to be, after plants, 14 new spunges, 2.N. 70 years and 40 years delay! G. Cryptogams, \&c.

70 years and 40 years daware 1815. Analysis of Nature, and District of Columbia, my with new orders and families, fret essay, suppressed by Dr. Palermo, 1 vol. 8vo.

firot essay, suppressed by Dr. Palermi, Etnensis or 4 florulas Benjamin Barton. 1804. Botanical letters. Mublenberg, Brickell, \&c.

1805. Discoveries in North nia.
Prodromus of New Genera.

America, Leghorn.

1807. Panphysis Sicula, Pamphlet. Prodromus, Palermo, 4to. fig. 1817. Florula Ladoviciana, 1808. N. Genera 10 and 60 containing so N. G. and 169 N. Sp. of American plants in N. Sp. 1 vol. 12mo. N. York. No. 44 of Medical Repository nensis and Oregonensis. Pam$\rightarrow$ re-printed in Pesia, 1809, and phlet.

nal of Botany, Paris, 1809,ares. Reviews of Pursh, Eaton, in Archives of Discoveries. Reviews of Pursh, In Am, Observations on American Bo- Barton, Bigejow, occ. in Am. tany in ditto.-Icones Nov. Monthly Nagaza, Ne Sciences Pantarum Americ. $40 \mathrm{pl}$. 1810. Now animals and or N. animals and Now York plants of Sicily, 1 vol. 4to. ditto, 3 decads of Ne plants. with 78 fig. Palermo.

Monograph of the $G$. Berto- 1818, Review of Nuttall and lopic. Elliott, in ditto.

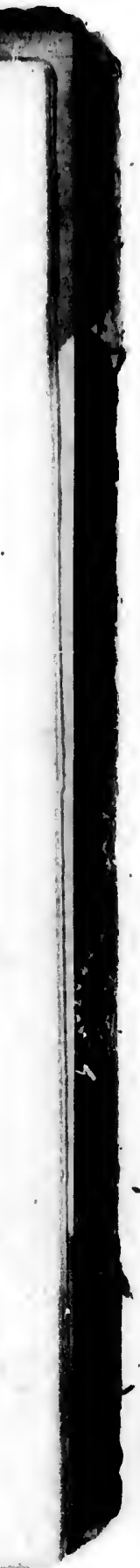




\section{8}

Discoveries in the Western 1830. American Vines-BoStutes in ditto.

1819. Remerks on American 1832. The American Forist

Geners of plants, 50 N. G. of 36 figs. 12mo. Fhiladelphia.

American plants and $70 \mathrm{~N}$. Atlantic Journal, Philada.

G. of animals. In the Journal 1832 and 1833 , containing 150

of Physlque, Paris.

N. $\mathbf{G}$ and 8 p. of plants from

New plants, spunges and ani- Alleghonics, Florida, Illinois, mals in Silliman's Journal, Canaila, Kentucky, dec.

Now Haven.

1839. Herbarium Rafinesqui-

1820. Annals of Naturc or anum or Prodromus of the now 25 N. G. and 124 N. Sp. of Sp. yet undescribed in his Heranimals and plants. Pamphlet, bal, 1 vol. Philada.

Lexington.

1815 to 1833. Autikon Bo-

Sketch of the Flora of Ken. tonikon or sclf figures of 2500

tucky, and several Tracts, in new or rare plants, chiefly col-

Western Review, Lexington. Plected in North America. Index

Monographs of the Genera to ditto, in three parts.

Rosa, Houstonia, Eustachya,

Iysimachia. N. G. Enemion.

1833 to 1835. Additional

-Order of Rubiaces classed, Florn of North America, or the

and soveral other botanical orders and families, Genera, tracts in ditto. Species and Varieties, omitted,

1821. Western Minerva, se- misnamed or misplaced by Linveral N. G. \&cc. suppressed by neus, Wildenow, Persoon, Demy rivals! candolle, Muhlenberg, Mi-

1822. The Cosmonist, 20 chaux, Lamark, Walter, Bosc, numbers, Lexington. Adanson, Necker, Agardh,

New plants of Kentucky. Lindley, Pursh, Nuttall, Elli-

1823. Prenanthes opicrina ott, Leconte, Marshall, Dar. and other plants, Cincinnatti. lington, Torrey, Bigelow,

1824. Florula Kentuckensis Beck, Eaton, Hooker, Schweiand Prodromus N. Sp. Lexing- nitz, \&c.

ton.

1808 to 1838. Amenities of

1825. Neogenyton or $66 \mathrm{~N}$. Nature; or collection of the

G. North Am. plants, pam-principal essays of C. S. Raphlot, Lexington.

Neocloris or N. Sp. of West- ces, \&c.

ern America.

1826. School of Flore, with figures, Philadelphia.

1828. Medical Flora of the

155. GEOGRAPHY.

U. States, 1 vol. 50 plates, $12 \mathrm{mo}$ Discovery of Linderby Land in the Aiustral Ocean.

$2 d \mathrm{rol}$. in 1830.

$\mathrm{T}$ had long been suspected that

large tracts of land existed near plants of N. America.

the South pole. In February 1831, Capt. John Biscoe, of

the 1

Mess

se.

undes

skirt

from

Lat.

Long

wich,

name

Cape

it. I

than

vente

at la

como

Bisco

Island

Shetlo

Adela

der $t$

near 1

land 0

1599,

many

Greer

Palm

deemi

cover

it ros

due $\mathbf{S}$

S. $\mathbf{S .}$.

Thi

has be

altho'

ers, ti

Capt.

plore

miral

belp 1

ograp

given

to $\mathbf{C a}$ 
the Brig Tula, belonglng to 156. GEOLOGY, Mese. Endorby of London, on AND PHYsical TEATUary a sealing voyage discovered Of the Atlantic plains of Drorth under tho Antarctic Circlo a America, by C. B. $\boldsymbol{R}$. large extent of hlgli-land, They form great natural ekirted by Ice, which runs features of the physical gongfrom $\mathbb{N}$. F. to 8 , W. between raphy and genlogy of North Lat. 65 and 70 8. and between America, which have herdly Long. 43 and 57 E. of Green-been properly noticed as yot. wich, to which he gave the The plaine along the atlantic name of Enderby land, and ocean, skirting the hilly primiCape Ann to a large cape on tive region, begin iu New-Jerit. He could not come nearer sey in Lat. 41, and extend than 20 miles of it, being pre- 8 . to Florida, thence W. to vented by a field of iee. Thus Texas, thence all around the at lant the Auatral lands be- gulph of Mexico to Yucatan, come gradually known. and even beyond to Veragua

In the samo voyage Capt. and Panama: forming thua Biscoe discovered a chuin of level litoral region nearly 4000 Islands to the 8 . W. of tire S. miles long, and from 100 to Shetlands, "which he called 150 miles wide oll an average, Adelaide Islands. they are un- the superficial Area exceeeding der the Antarctic Circlo and 400,000 square milea! the near the west side of the great whole of which is lovel, witl land of Gheritz, discovered in the exception of a fow scattor1599, which has receired so ed and insulated hills of amalt many names lately, South/elevation.

Greenland, South Spitsberg. A volume could be writton Palmerland, \&ce. Capt. Biscoe on the geography, geology deeming this west sliore a dis-and natural history of this vast covery called it Graham land, region: my limits compel me it reaches as far us Lat. 68 to give meroly a reciapitulation due S. of cape Horn, running of the principal features and S. S. W. phenumena of it.

This voyage of discovery 1 . Theso immenes plains has been deemed so important, rise only 50 feet above tide altho' unprofitable to the own- water on average, or from 25 ers, that they have sent again to 75 feet.

Capt. Biscoe to survey and ex- 2. The surface is hardly unplore these lands, and the ad- dulated, the streams lave exmiralty has sent Capt. Rea to cavated broad and shallow valhelp him. Thie Society of Ge-leys and beds, with vide estuography of London have also aries at their miouths.

given their gold medal for.1832 3 . They may be divided into to Capt. Biscoe as a roward. several tracts, 1. the Northern as far as the Chesapeak bay.

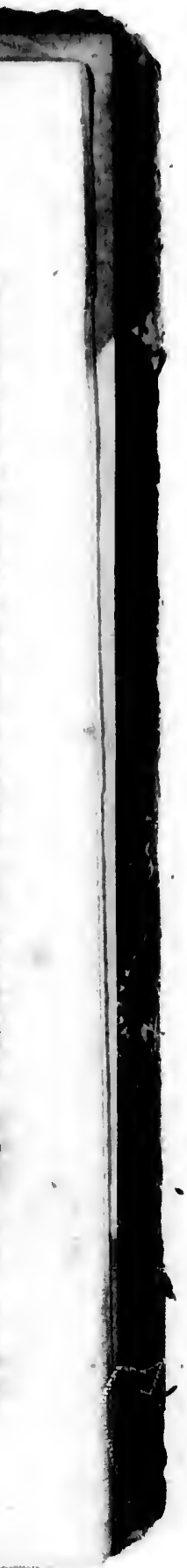




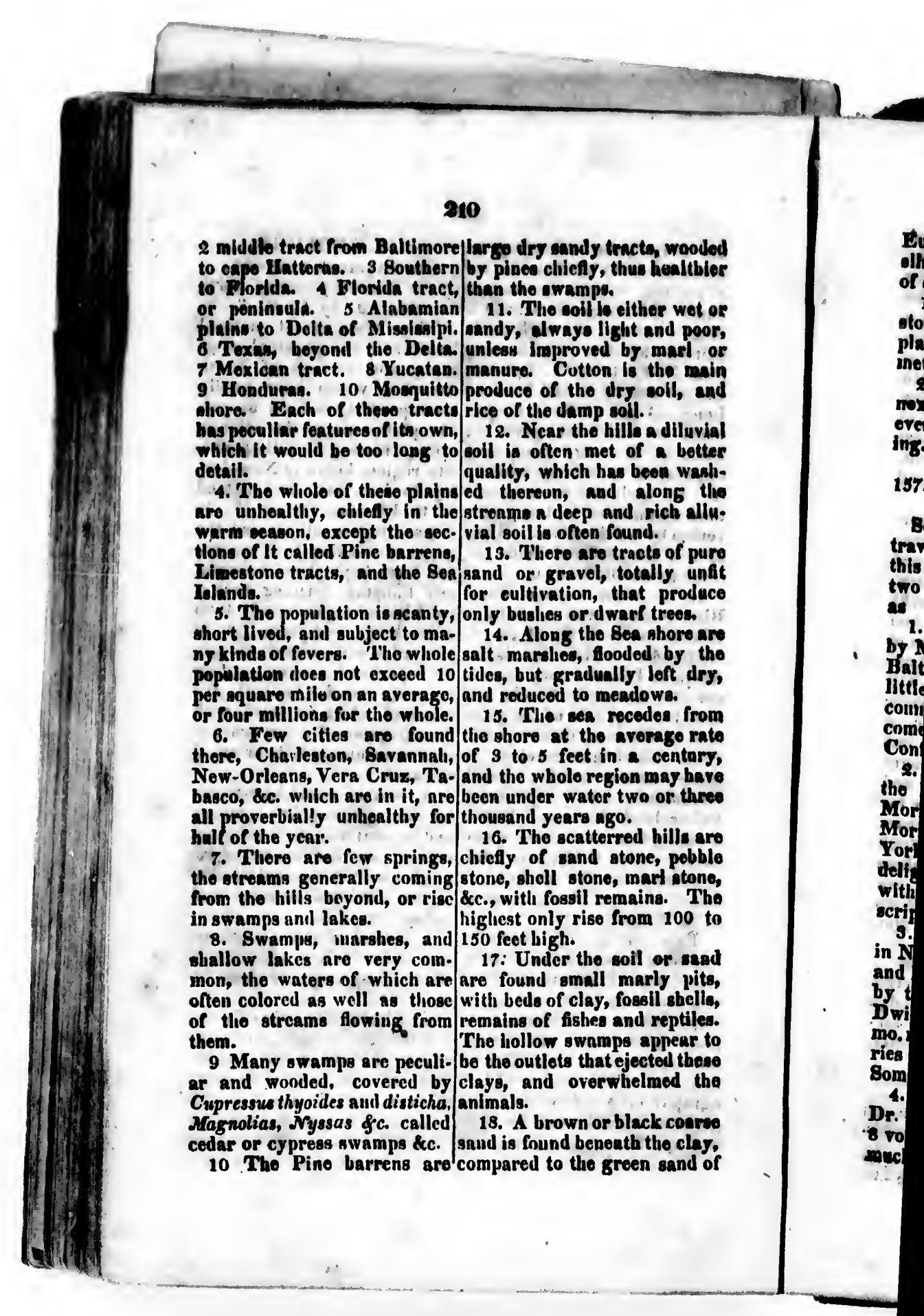


turope, but holding other fos-ftinople, althongh he was only alh. Then come other mtratas a few munths there. Ho praices of clays. 19. Bog Iron and Iron Groeka.

stones are found in many 5. Voyage of Capt. Fannia placea, but hardly any other round tlie world dec., 1 vol. \& ro. New Tork, fic. Important,

20. Mosquitoes, Alies and it embraces over thirty yeare of moxious Insects aro common travels and discuvories by himovery whore, and very annoy-aelf and others. ing.

6. Travela in Now Mexico and California, by Opattio 157. American Travels publish-Cincinnatti, vol. $12 \mathrm{mo}$. ff. ed in 1833.

Very interesting journal of a

Beveral important original trapper and trailer.

travels have been published 7. Account of un expedition this year In the United States, to the Oregon or Rocky Mts. two of which by ladiea! such by Wyeth. Pamphlet, Boston. as

1. Observations on Texas, by Mrs. Holloy, 1 rol. 12 mo. Baltimore, majl. Very clover As cally as 1827 . I proposed count of that country, now be- nale, weekly at one doliar por come a State of the Mexican annum, dally at five dollars, Confederation. and proved the possibility of

2. Tarrative of a voyago to these useful undertakings for the Pacific Ocean, by Mrs. the diffusion of knowlodge. I Morrell, the wife of Capt. was not believed then, as often Morrell, 1 rol. 16 mo. Now liappens with my useful pro. York, with her nortrait. A jects, and no one would join delightful little bonok, written me to begin the experiment.? with feeling and graphic de. In 1831 . I issued proposals, acriptions. and in 1832 began the publica-

3. Travels and researches tion of this Atlantic. Journal on in Natolia, Armenia, Georgia my individual means and exerand Persion in 1830 and 1831, tions. If I had been sustained by the Rov. Eli Smith and H. in my endeavours to blend sciDwight. Boston, 2 vola. 12 entific with popular knowlmo. man. American missiona- edge, I would have furnished ries sent to explore Armenia. the cheapest periodical in tho Bomo useful and curious facts. United States, twolve number

4. Sketchea of Turkey, by yearly of nearly 400 pages \& 24 Dr. Dokay, New York, 1 vol. figures for one slollar! But this - vo fig. "Well written, and required a greater number of much information on Constan-subscribers than I was able to 


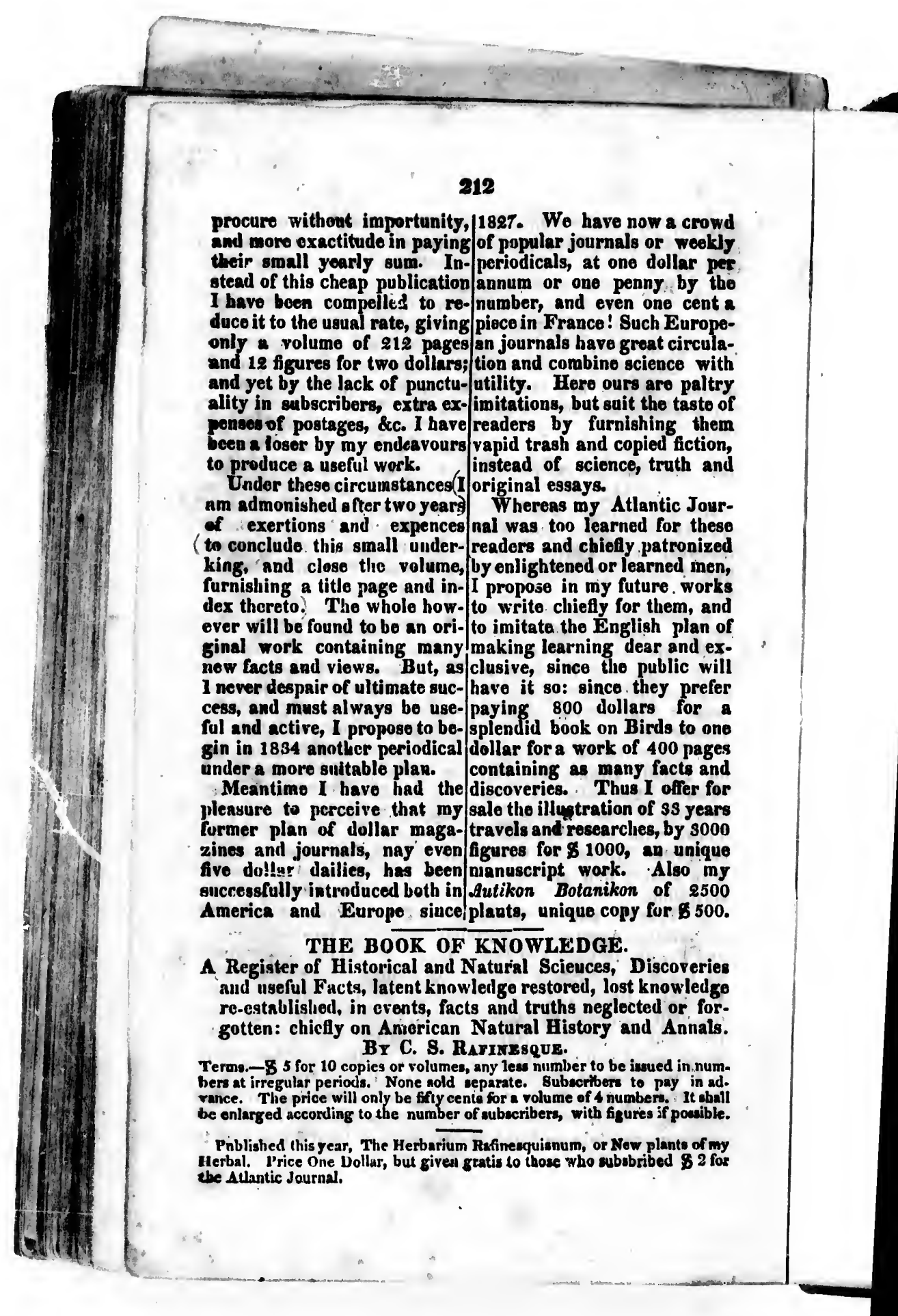




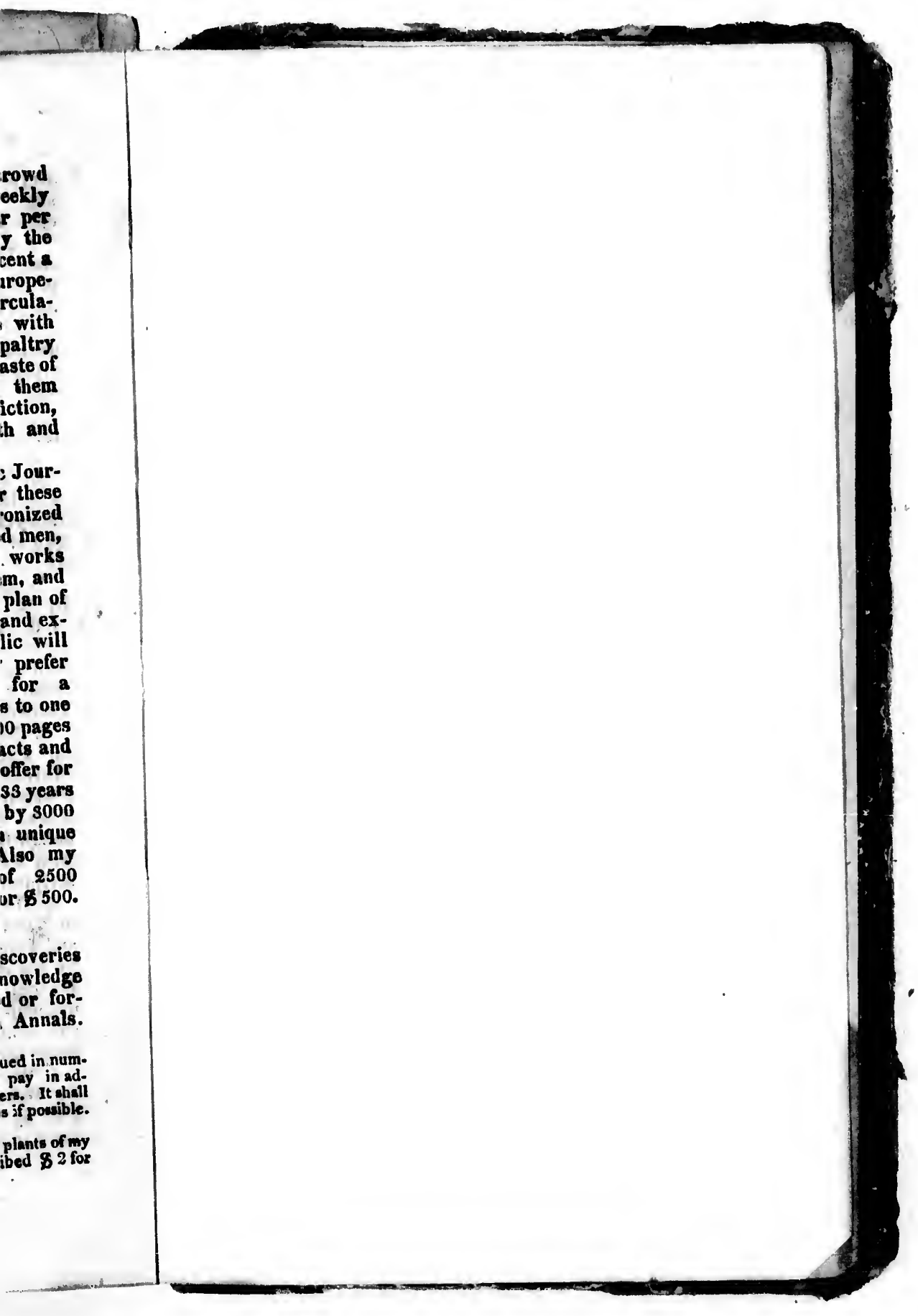




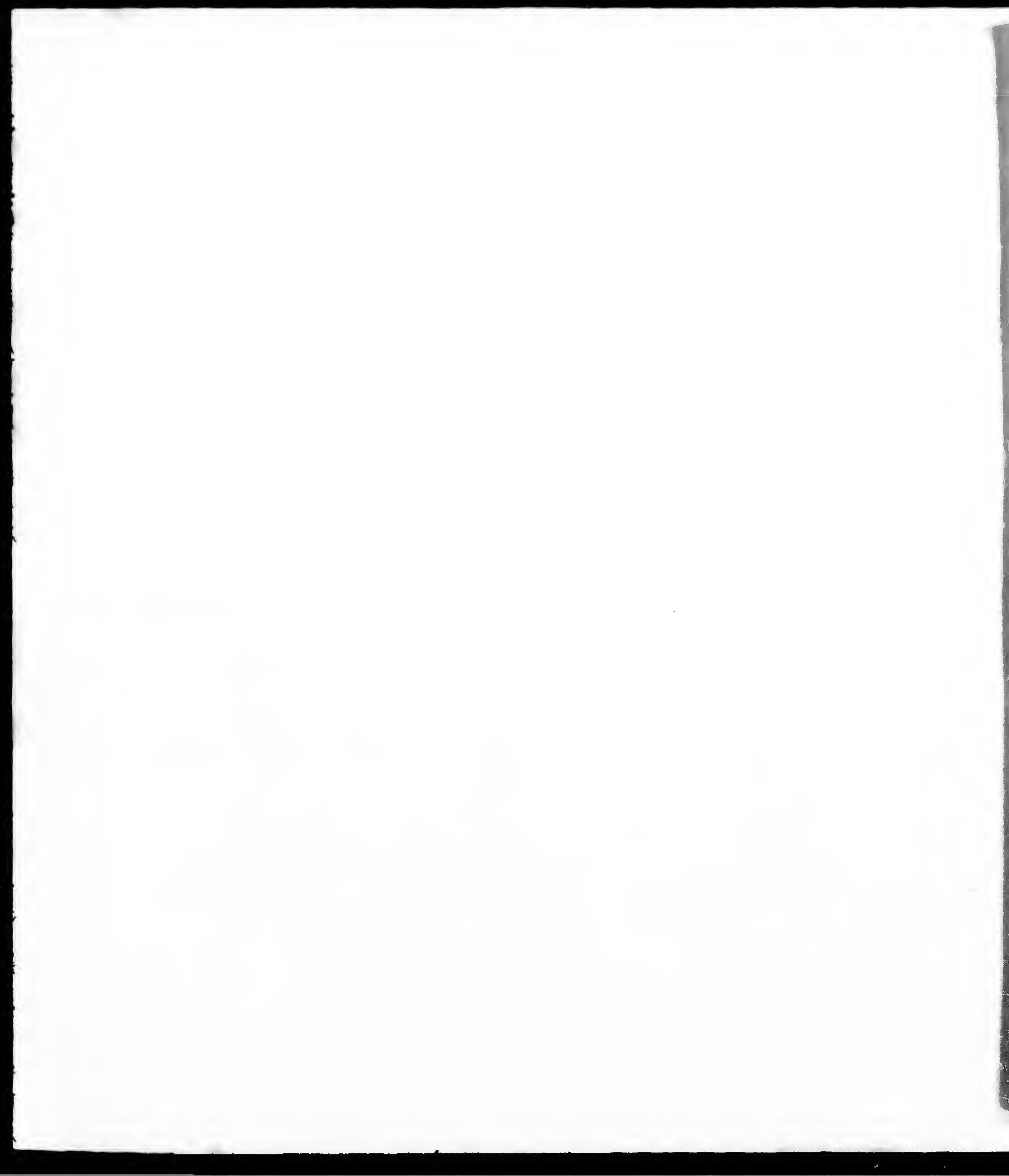




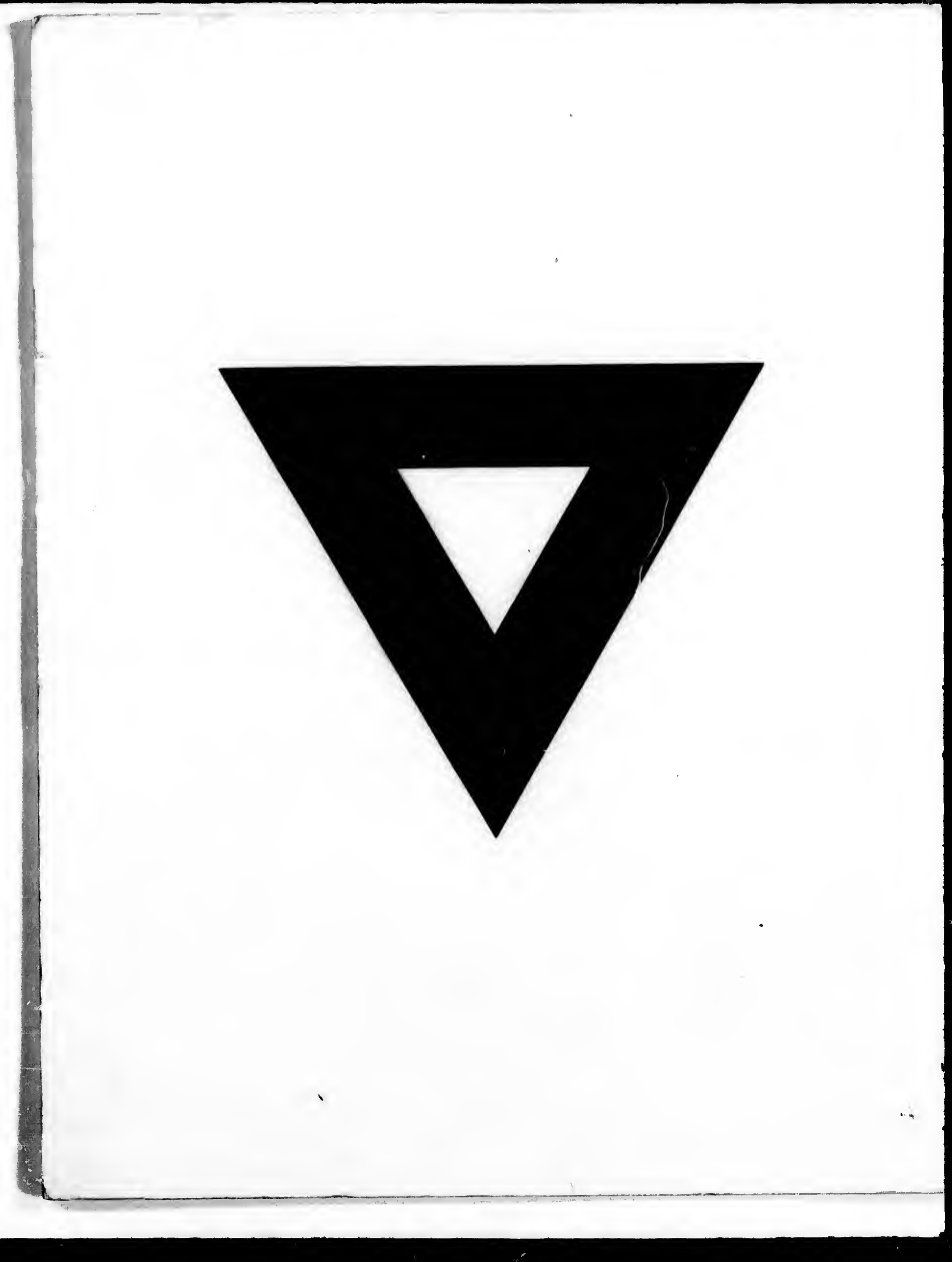

